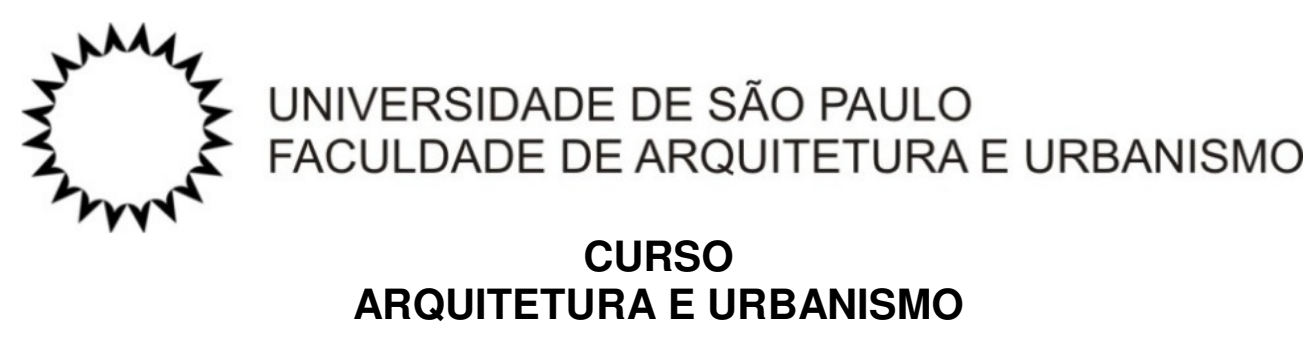

SERGIO RUGIK GOMES

A ARQUITETURA DAS SINAGOGAS:

EXEMPLOS RELEVANTES E SUA TRANSFORMAÇÃO NO TEMPO 


\section{A ARQUITETURA DAS SINAGOGAS: \\ EXEMPLOS RELEVANTES E SUA TRANSFORMAÇÃO \\ NO TEMPO}

Dissertação apresentada a Faculdade de Arquitetura e Urbanismo da Universidade de São Paulo para obtenção de título de mestre em Arquitetura e Urbanismo, com Área de Concentração em Projeto de Arquitetura.

Orientador: Prof. Doutor Francisco Segnini Junior. 


\section{A ARQUITETURA DAS SINAGOGAS: \\ EXEMPLOS RELEVANTES E SUA TRANSFORMAÇÃO \\ NO TEMPO}

Dissertação apresentada a Faculdade de Arquitetura e Urbanismo da Universidade de São Paulo para obtenção de título de mestre em Arquitetura e Urbanismo, com Área de Concentração em Projeto de Arquitetura.

Orientador: Prof. Doutor Francisco Segnini Junior.

COMISSÃO EXAMINADORA:

Orientador: Prof. Doutor Francisco Segnini Junior.

São Paulo de de 2011. 


\section{AGRADECIMENTOS}

Primeiramente ao Deus Eterno, pois este tem a primazia. À minha esposa Taritha, maior incentivadora. Aos meus pais Theóphilo e Evone, que tanto amo. À querida tia Maria Lúcia Marcondes de Mattos. A Toshiro e Aya Momoi. A Thomas e Dorothy Hargest.

Ao meu caro orientador, professor Doutor Francisco Segnini Jr. À Professora PósDoutora Anat Falbel. À professora LD. Monica Junqueira. À professora Pós-Doutora Ana Paula Simioni. Ao professor Doutor Jorge Marão Carnielo Miguel. Ao Professor Mestre Sergio Kopinski Ekerman. À professora Doutora Erica Yukiko Yoshioka e Doutora Helena Aparecida Ayoub Silva, que tornaram a qualificação o melhor momento do percurso. Ao amigo Paulo Mendes.

Ao Senhor Alberto da Federação Israelita de são Paulo. Aos senhores Mauro e José Roberto da comunidade judaica de Santos. Ao Senhor Gean do Centro de Cultura Judaica. Ao Senhor Léo Kriger, presidente da Federação Israelita do Paraná. À querida colega Flô e sua tia. À querida colega Ana Lacerda. Ao Arquivo Histórico Judaico Brasileiro.

Aos caros Alexandre Raul de Almeida, Helio Biagio e Silvia Albuquerque. Aos funcionários da biblioteca, recepção e secretária da FAU-Maranhão, sempre cordiais. À Universidade de São Paulo.

Aos que porventura tenham escapado à memória falível, mas sem os quais este trabalho não teria sido possível. 
GOMES, Sergio Rugik. A arquitetura das Sinagogas: exemplos relevantes e sua transformação no tempo. 2011. 130 p. Dissertação (Mestrado em Arquitetura). Universidade de São Paulo - USP. São Paulo.

\section{RESUMO}

A ancestralidade do edifício sinagogal atribuiu a este um papel central na formação da arquitetura religiosa ocidental. Entretanto sua adaptação à localidade, no decorrer dos séculos, concedeu-lhe os mais variados repertórios. Aspectos ligados ao uso, porém, demandaram soluções espaciais para problemáticas que permaneceram ao longo do tempo. Essas soluções que envolvem o programa de necessidades dos edifícios, sua dimensão e capacidade de uso, suas relações com a arquitetura das diferentes localidades e as consequentes ações de preservação da identidade e a organização dos elementos da liturgia, dentro do espaço interno do edifício, geraram as transformações que, reunidas, constituem uma radiografia da arquitetura da sinagoga no tempo.

Palavras-Chave: Arquitetura. Sinagoga. Transformação. Tempo. Programa. Localidade. Ordenação Interna. 
GOMES, Sergio Rugik Gomes. The architecture of the Synagogues: relevant examples and its transformation in time. 2011. 130 p. Dissertation (Master Degree in Architecture) Universidade de São Paulo - USP. São Paulo.

\begin{abstract}
The ancestry of the synagogue building attributed to this a central paper in the formation of the religious architecture occidental person. However, its adaptation to the locality in elapsing of the centuries granted to it the most varied repertoires. On aspects to the use, however, had demanded space solutions for problematic that they had remained throughout the time. These solutions that involve the program of necessities of the buildings, its dimension and capacity of use, its relations with the architecture of the different localities and the subsequent actions of preservation of the identity and the organization of the elements of the liturgy inside of the internal space of the building, had generated the transformations that, congregated, constitute a picture of the architecture of the synagogue in the time.
\end{abstract}

Keywords: Architecture. Synagogue. Transformation. Time. Program. Locality. Internal Ordinance. 


\section{SUMÁRIO}

INTRODUÇÃO..................................................................................... 9

CAPÍTULO 1 - DEFINIÇÃO E ORIGENS..................................................... 18

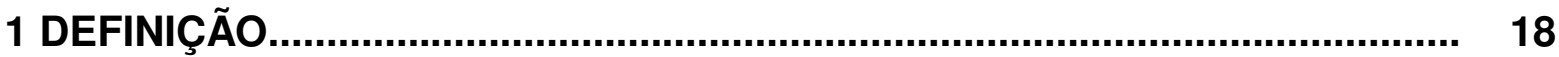

2 O TABERNÁCULO E O TEMPLO DE JERUSALÉM...................................... 19

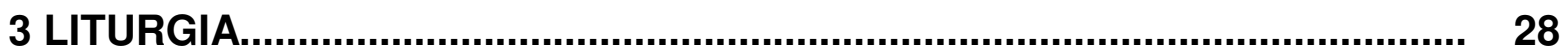

3.1 O Talmud

3.2 A Arca

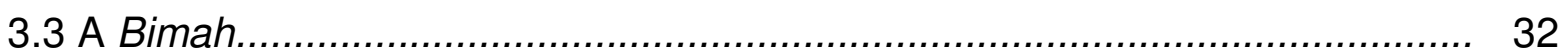

3.4 Orientação do Edifício............................................................. 33

3.5 Pátio e Vestíbulo....................................................................... 34

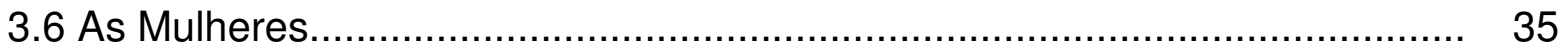

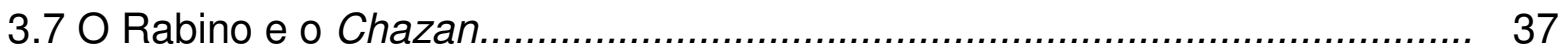

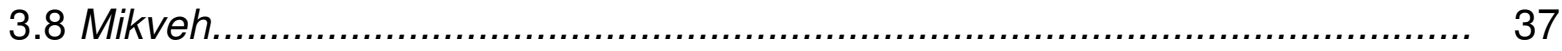

3.9 Símbolos e Decoração......................................................................... 38

CAPÍTULO 2 - EVOLUÇÃO NO TEMPO …................................................ 40

10 TEMPLO DE JERUSALÉM..................................................................... 46

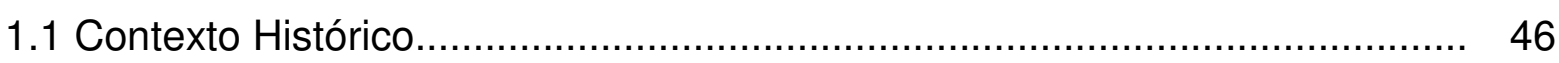

1.2 Programa de Necessidades.............................................................. 47

1.3 Influência da Localidade......................................................................... 49

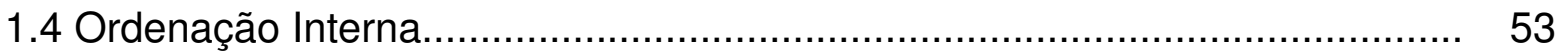

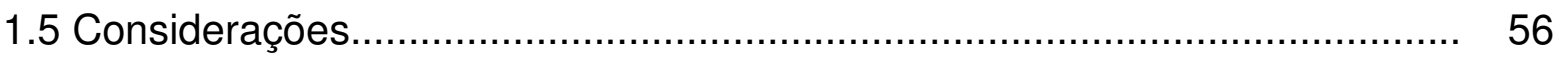

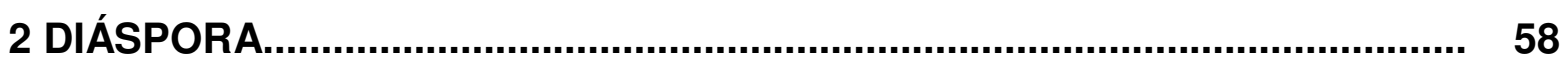

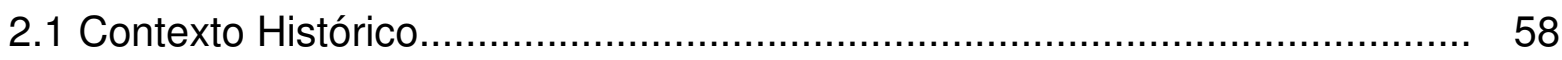

2.2 Programa de Necessidades............................................................... 59

2.3 Influência da Localidade........................................................................ 64

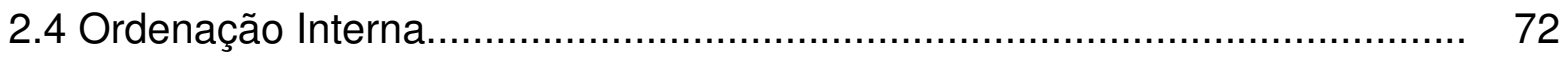

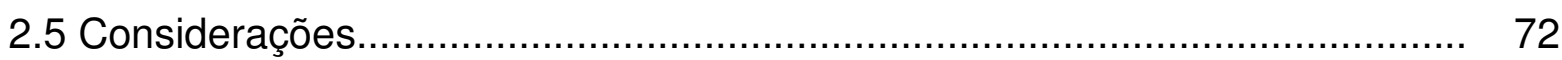

3 ASCENSÃO DO CRISTIANISMO............................................................... 74 


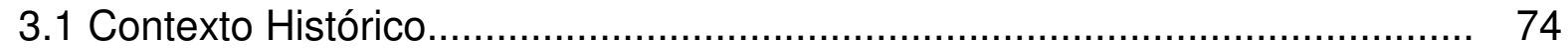

3.2 Programa de Necessidades.............................................................. 75

3.3 Influência da Localidade................................................................. 80

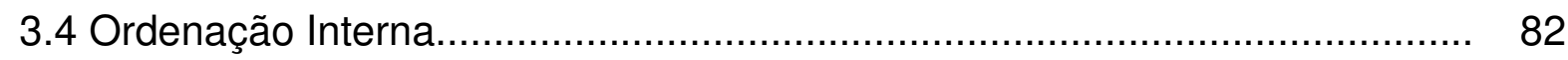

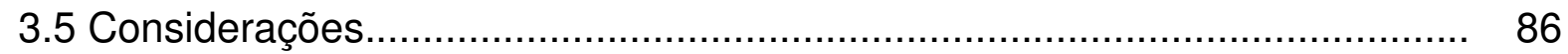

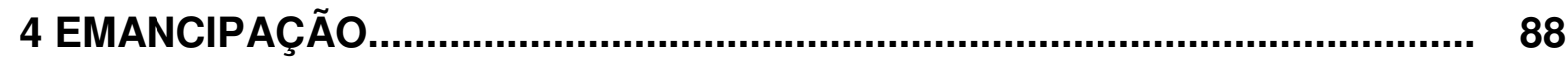

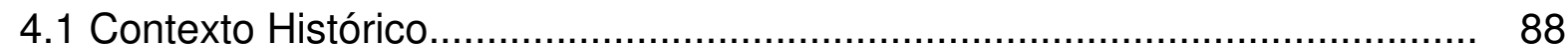

4.2 Programa de Necessidades............................................................... 89

4.3 Influência da Localidade...................................................................... 90

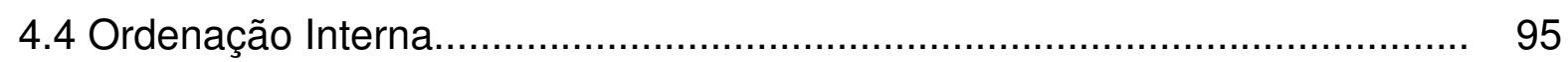

4.5 Considerações.............................................................................. 99

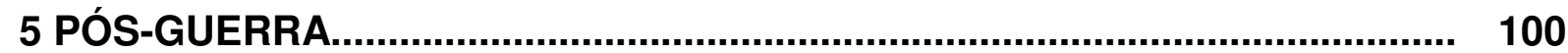

5.1 Contexto Histórico........................................................................ 100

5.2 Dimensões e Programa............................................................... 101

5.3 Influência da Localidade e Preservação da Identidade................................ 103

5.4 Ordenação Interna.................................................................... 106

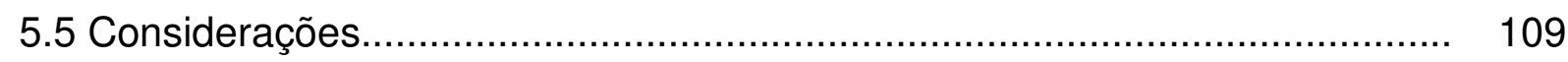

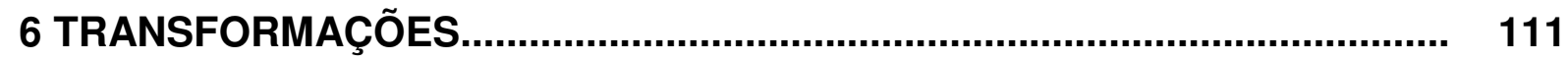

7 CONSIDERAÇÕES FINAIS................................................................... 113

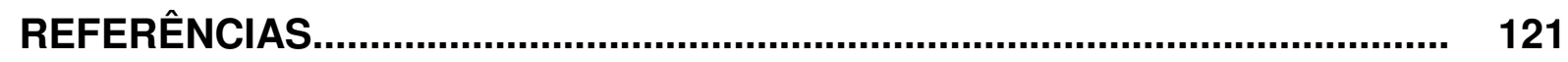

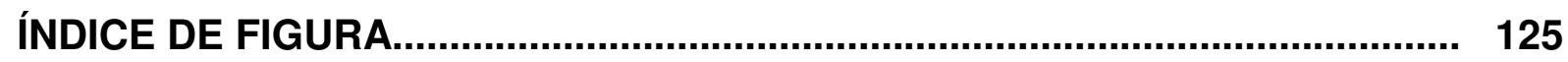




\section{INTRODUÇÃO}

A sinagoga existe há quase três mil anos e ainda permanece em pleno vigor na atualidade. Mais antiga que a igreja cristã e a mesquita muçulmana, ela foi testemunha da ascensão e decadência de civilizações e impérios. Seus edifícios são um registro dos percursos do povo judeu pelas nações onde foram exilados, revelando em sua arquitetura a influência das diversas culturas e diferentes épocas que se estabeleceram. Espalhadas por quase todo o globo, da galeria Victorio Emanuelle em Milão (fig. 1), nas ruas de Cingapura (fig. 2), sua arquitetura apresenta os mais diversos estilos e sistemas construtivos, para abrigar desde um pequeno grupo até milhares de pessoas.

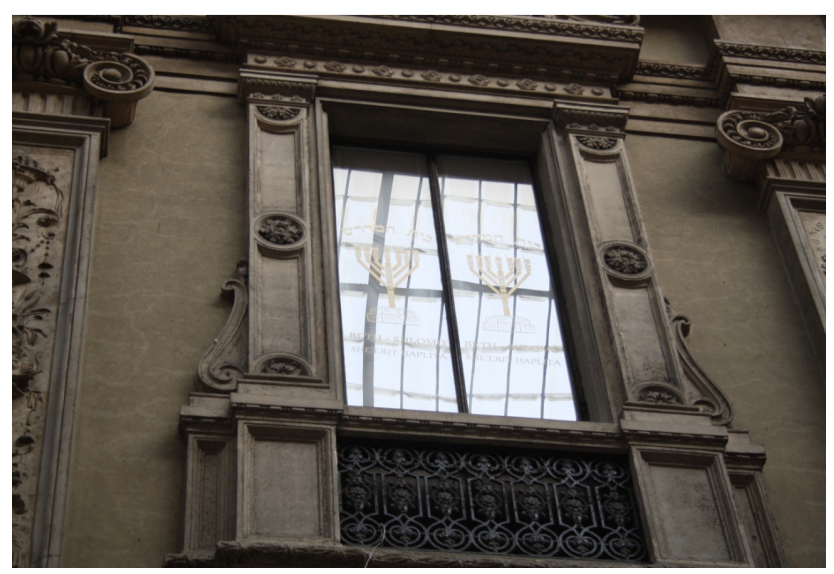

Figura 1: Sinagoga Beit Shlomo na Galeria Victorio Emanuelle em Milão, Italia. Foto: Sergio Rugik Gomes.

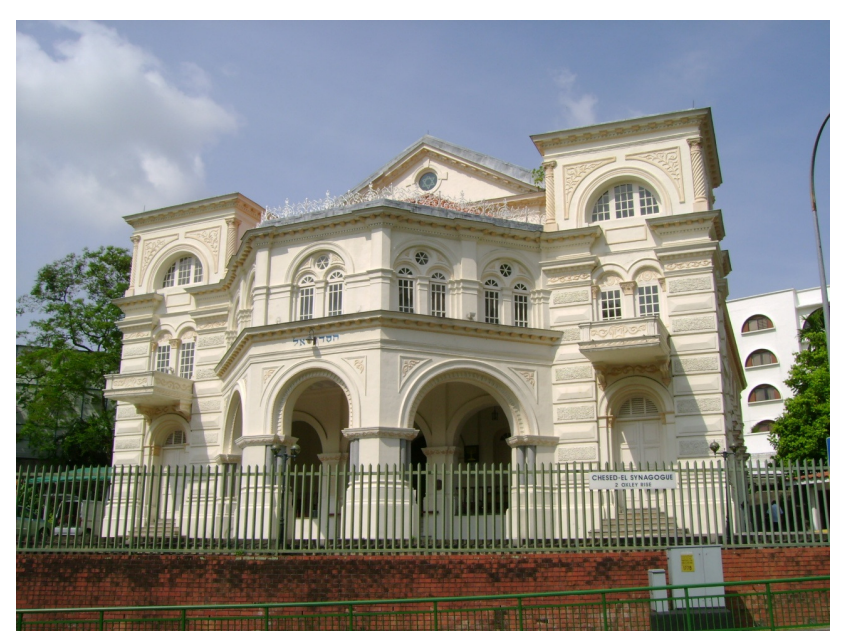

Figura 2: Sinagoga Chesed-El em Cingapura. Foto: Sergio Rugik Gomes. 
Sua origem remete ao Tabernáculo de Moisés ${ }^{1}$, o edifício central do culto judaico, a antiga tenda sacrificial dos hebreus. A sinagoga é profundamente ligada a esse edifício da antiguidade. Ele é o exemplo apresentado por Rykwert (2003) em seu livro intitulado A casa de Adão no paraíso: a idéia da cabana primitiva na história da arquitetura, ao tratar do que ele chama de uma "inquietante persistência" na busca pelas recordações da natureza da primeira casa.

(...), uma vez que tal visão parece ter perseguido todos os envolvidos em construção (muito antes desta ter se distinguido da arquitetura), eu gostaria de traçar o caminho no qual, em diferentes contextos, algumas recordações deste tipo ocorreram, e, a partir da inquietante persistência desta visão, traçar algumas conclusões sobre a natureza da primeira casa (RYKWERT, 2003, p.4).

Ao citar o Tabernáculo dos Hebreus, Rykwert (2003) se utiliza do exemplo que Le Corbusier (1973) escolheu para falar da cabana primitiva, como uma evidência das recordações da primeira casa. Não é possível afirmar por que Le Corbusier escolheu esse exemplo, mas é sabido que tanto o Tabernáculo como seu substituto, o antigo Templo de Jerusalém, foram exaustivamente estudados e utilizados como modelo a construção de igrejas, sinagogas e outros edifícios em todo o mundo, não apenas na antiguidade ou na idade média, contudo recentemente como, por exemplo, no padrão de referência, proposto por Louis Kahn, para o projeto do "Memorial aos Seis Milhões de Mártires Judeus" em Nova York (SMITH, 2004) (fig.4) e o projeto proposto para reconstrução da sinagoga Hurva em Jerusalém (HOLLENSTEIN, 2003).

O Tabernáculo remete ao modelo celestial, o edifício perfeito da morada de Deus, cuja construção foi ordenada a Moisés pelo próprio Deus: "Levantarás o Tabernáculo segundo o modelo que te foi mostrado no monte" (BÍBLIA HEBRAICA, 2006, Êxodo: 26:30). O Templo de Jerusalém foi o edifício que o substituiu quando Israel instalou-se na "terra prometida", atual palestina. Sua organização seguia as mesmas determinações divinas presentes em seu antecessor, e este último também levava o status de santuário do Altíssimo. A sinagoga veio em seguida. Mesmo não recebendo a mesma importância como casa

\footnotetext{
${ }^{1}$ O Tabernáculo de Moisés foi um Templo, como tenda, edificado por Moisés no deserto, líder hebreu que conduziu os judeus, ou mais corretamente os hebreus, em sua saída do Egito por volta do século XVI a.C.

2 Terra prometida é a denominação dada à antiga terra de Israel, cuja herança foi prometida por Deus à Abraão, patriarca do povo judeu.
} 
de Deus, ela carrega consigo diversos conceitos do Tabernáculo e do Templo e vai se estabelecer como mantenedora da identidade e da religião judaica. Sua arquitetura remete a estes dois edifícios sagrados, trazendo em si a lembrança deste edifício celestial, e talvez das recordações da primeira casa.

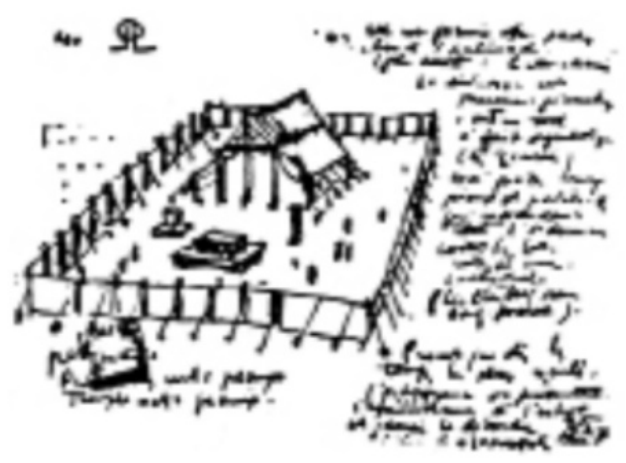

Figura 3: Croqui de Le Corbusier do Tabernáculo de Moisés.

Fonte:<http://www.ufrgs.br/propar/publicacoes/ARQtextos/PDFs_revista_12/03_SC_ronchamp_30409 .pdf > Acesso em: 22 dez. 2010

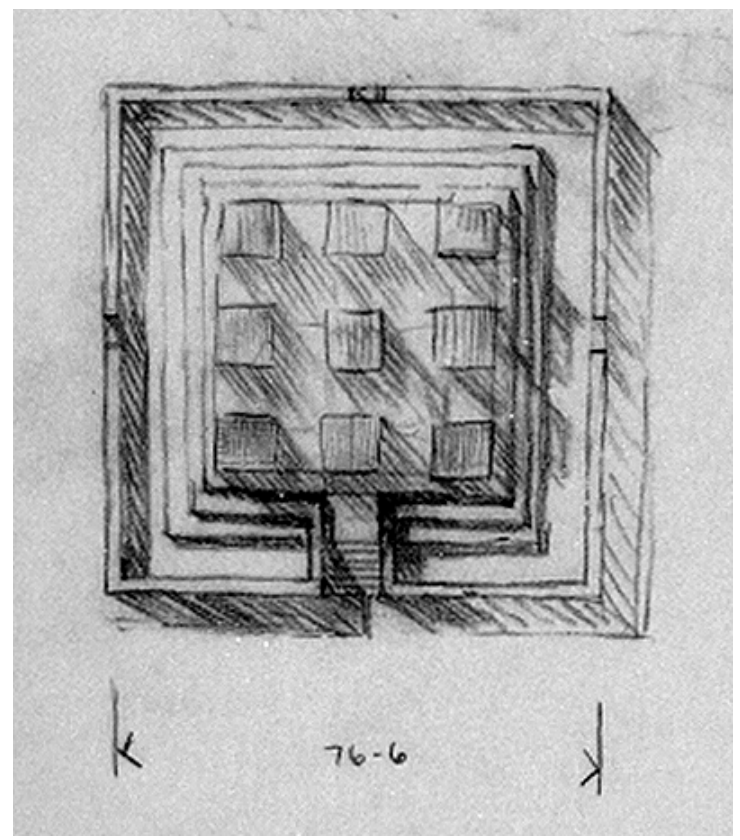

Figura 4: Croqui do memorial para os seis milhões de mártires judeus de autoria de Louis Kahn. Fonte:<http://www.design.upenn.edu/archives/majorcollections/kahn/martyrsplan.gif> Acesso em: 30 dez. 2010.

Como edifício central da religião judaica desde a antiguidade tardia, a sinagoga representa um importante elemento de referência do povo judeu. Ela tornou-se o foco central nos debates sobre uma linguagem judaica na arquitetura, principalmente depois dos eventos que envolveram a comunidade judaica no século 
$X X$, como o holocausto ${ }^{3}$ ou o sionismo ${ }^{4}$. Esses debates vão se intensificar principalmente no âmbito do movimento moderno, com a contribuição de arquitetos como Erich Mendelsohn (1887-1953) ao prover uma conexão positiva e final entre a destruição do holocausto e a aspiração dos objetivos dos judeus da América do pósguerra (GRUBER, 2004).

Esse caráter atemporal e onipresente concedeu à sinagoga uma riqueza milenar que a ela se agregou ao longo dos séculos. Entretanto o conhecimento a seu respeito parece confuso e pouco disseminado, inclusive no meio acadêmico. Quanto à arquitetura de seus edifícios, poucas são as publicações a seu respeito, e as que existem a observam sob diferentes abordagens, que envolvem religião, cultura, história, arqueologia ou temas diversos relacionados ao povo judeu com apenas breves menções sobre seus edifícios de culto.

Tendo em vista o desconhecimento do tema e as poucas publicações relacionadas, faz-se pertinente, no presente momento, uma apresentação do universo arquitetônico da sinagoga, trazendo antes informações básicas para a compreensão da instituição. Entretanto esse universo engloba exemplos construídos tanto na antiguidade quanto nos dias atuais, em estilos diversos e em diferentes países.

Desde sua origem, a história do povo judeu é marcada pela relação entre casa e exílio. Voolem (2004) afirma que o "exílio é a essência do povo Judeu". Inicia com a ida de Abraão, patriarca dos judeus, da Caldéia, à "terra prometida", passando pelo êxodo do Egito, pelo exílio na Babilônia em 598 a.C., pela diáspora de 70 d.C. ${ }^{5}$, pelas migrações e imigrações antes de depois da guerra até o retorno ao recém criado Estado de Israel, oficializado pela ONU em 1948. EISEN (1984, p.xi - trad. nossa) vai além ao afirmar que:

No princípio houve o exílio (...). Deus mal havia acabado de por o selo de Sua perfeita ordem, como nos conta o livro de Gênesis, quando suas criaturas incorreram em punição eterna por interrompê-la. O Paraíso ainda não havia se tornado uma casa quando os pais de todos nós foram lançados para fora dele, para nunca retornar.

\footnotetext{
${ }^{3}$ Holocausto é o nome dado ao extermínio de judeus nos campos de concentração nazistas durante a segunda guerra mundial.

${ }^{4}$ Sionismo é um movimento surgido no século XIX que defendia a criação de um estado judaico na palestina e o retorno de todos os judeus a este estado.

${ }^{5} \mathrm{O}$ termo diáspora refere-se à dispersão do povo Judeu em 70 d.C. quando a cidade de Jerusalém foi destruída por exércitos romanos.
} 
Essa configuração não permite uma abordagem destas obras sob a perspectiva de um movimento arquitetônico específico, limitada a uma determinada época ou localidade. Entretanto os estudos dos tipos arquitetônicos analisam as edificações sob o escopo das transformações do espaço geradas pelas mudanças nas condições históricas. Giulio Carlo Argan (2004), ao tratar sobre o conceito de tipologia arquitetônica, esclarece que os tipos são resultantes de "exigências profundas" de uma determinada civilização. Devido às interferências que cada localidade impôs sobre os hábitos de vida e as práticas sociais das comunidades judaicas, as condições formadas pelo exílio influenciaram profundamente a arquitetura de seus edifícios, gerando as transformações pelas quais a sinagoga passou ao longo dos séculos. Alfonso Corona Martínez (2000, p. 120) sugere que:

\footnotetext{
Enquanto o tipo representa as constantes por um período determinado, os exemplos atípicos ou transformações representam as possibilidades de mudanças impulsionadas por mutações nos hábitos de vida e nas práticas sociais. As transformações são o meio de geração de novos tipos, uma resposta da arquitetura à vontade social de mudanças.
}

Como o presente estudo se propõe à apresentação de um panorama universal das sinagogas ao longo da história, sob o ponto de vista de ser o espaço arquitetônico, o critério de abordagem adotado para esta apresentação foi o da observação das transformações dos edifícios ocorridas no tempo. Como essas transformações se dão em uma rede complexa de influências e ações decorrentes destas influências, outros critérios de classificação se fazem necessários. Ao definir o tipo arquitetônico, Vittorio Gregotti (1975, p.147) o faz em dois estágios:

a) como modelo de onde extrair cópias e esquemas de comportamento (enquanto resume os traços característicos de um grupo de fenômenos); b) como conjunto de traços característicos, cuja descoberta, num fenômeno determinado, nos permite sua classificação.

Dada essa definição, ele continua, ainda, explicando sobre a necessidade de diversos níveis de classificação para a análise dos edifícios, do ponto mais interno do objeto aos níveis mais exteriores. Posto isto, o primeiro critério de classificação adotado para a análise das sinagogas foi o da organização cronológica. Uma abordagem geográfica teria de se limitar a edifícios construídos em um determinado local, abandonando assim períodos históricos importantes para 
a compreensão geral do objeto, cujas sinagogas se desenvolveram em outras localidades. Assim sendo, optou-se pelo primeiro critério.

Os edifícios foram, então, agrupados em cinco recorrentes períodos da história. O critério de divisão adotado foi o da similaridade das condições às quais foram sujeitas as comunidades judaicas, capazes de gerar transformações em sua arquitetura. Os cinco períodos são:

1. O Templo: que reúne os edifícios contemporâneos ao Templo de Jerusalém, objeto que teve papel fundamental na formação das características da sinagoga deste momento.

2. Diáspora: que traz as sinagogas edificadas ao redor do mundo antigo, cuja catastrófica influência do exílio trouxe mudanças profundas em sua configuração.

3. Cristianismo: que cobre os séculos onde as comunidades judaicas foram sujeitas a diversas restrições e perseguições, expressas em sua arquitetura.

4. Emancipação: que trata das sinagogas construídas depois da concessão de direitos civis aos judeus da Europa e das consequências de tal momento em seus edifícios.

5. Pós-guerra: que aborda os edifícios edificados depois do holocausto e da criação do Estado de Israel, e como estes refletiram tais acontecimentos.

Com o passar do tempo, os problemas na concepção do espaço da sinagoga vão permanecer os mesmos. Entretanto as soluções a eles dadas vão se alterar na medida em que mudam as condições históricas. Essas soluções constituem os traços característicos dos edifícios em seus determinados períodos. É com base nessas soluções dadas a esses problemas que os edifícios serão analisados. Elas foram separadas em três categorias.

A primeira refere-se às transformações ocorridas nos programas de necessidade dos edifícios, bem como em sua dimensão e capacidade de uso como reflexo das condições geradas pelas configurações sociais de cada época e localidade. A segunda trata das relações entre influência da arquitetura das diferentes localidades e as ações de preservação da identidade. A terceira 
apresenta as formas em que foram organizados os elementos da liturgia dentro do espaço interno do edifício, em alguns casos como essa ordenação afetou sua orientação e quais as soluções espaciais adotadas quanto adotada a separação entre homens e mulheres.

Dessa forma, dentro de cada período os edifícios foram agrupados não em ordem cronológica, mas de forma a clarificar as soluções dadas a estes problemas característicos de cada um dos momentos históricos. Apesar de alguns desses períodos possuírem um grande número de edifícios construídos, alguns poucos exemplos contundentes foram selecionados, cujo critério adotado foi sua capacidade de demonstrar as mudanças próprias de sua época.

O trabalho então se inicia com o capítulo um, onde são estendidas as bases para compreensão do objeto, definido seu uso, apresentando algumas das hipóteses relacionadas à sua origem na antiguidade e expondo os elementos presentes em sua liturgia. No capítulo dois foi desenvolvida a apresentação dos períodos de seus respectivos edifícios, dissertando-se sobre as soluções dadas a problemas característicos de cada época, como mencionado anteriormente. Baron (1974, p.1) explica que:

Os estudiosos judeus e não judeus há muito reconheceram que a história judaica, especialmente depois dos dois milênios e meio de dispersão, não pode ser compreendida sem o background das várias civilizações entre as quais os judeus vieram a existir.

Dessa forma, abrindo cada um dos períodos, uma breve apresentação do contexto histórico traz as informações básicas necessárias para a compreensão das condições que as comunidades encontraram naquele momento. Dentro do capítulo dois estão dispostos também uma relação cronológica dos edifícios chamada de "Linha do Tempo" e uma tabela cujas soluções arquitetônicas foram distribuídas conforme seu período, para maior clareza dos resultados obtidos na pesquisa.

As informações quanto à liturgia foram levantadas de fontes tanto secundárias como primárias por meio de visitas a sinagogas no Brasil, como a Sinagoga Francisco Frischmann em Curitiba, de 1960, a Sinagoga Beit Sion em Santos, 1935 e a Sinagoga Beit Jacob, também em Santos. Foram visitados o Arquivo Histórico Judaico Brasileiro, além contatos e encontros com membros das 
comunidades de São Paulo, Santos e Curitiba. A maior parte dos edifícios foi elencada de fontes secundárias, com exceção de alguns exemplos na Itália, Cingapura e finalmente Israel, onde também foram obtidas informações relacionadas a aspectos culturais, necessárias aos entendimentos sobre o objeto.

Dentre as publicações científicas consultadas, destaca-se em língua portuguesa o trabalho de Sergio Ekerman (2007) que traz um levantamento de diversas sinagogas do pós-guerra até a contemporaneidade, vistas sob o escopo do estabelecimento do movimento moderno e de sua influência sobre o judaísmo. Seu trabalho apresenta o pensamento de arquitetos modernos que influenciaram toda uma geração de edifícios sinagogais. Outro título importante é o livro "Arquitetura e Judaísmo: Mendelsohn" com textos de Bruno Zevi (2002), organizado pela profa. Dra. Anat Falbel, que trata de importantes temas como a questão espaço temporal na arte, com relação à identidade judaica na arquitetura.

Dentre as publicações em língua inglesa, pode-se citar o trabalho do professor Lee Levine (2005), The Ancient Synagoue: the first thousand years sobre as sinagogas da antiguidade. Sua abordagem traz informações muito pertinentes sobre as primeiras sinagogas, contemporâneas ao Templo de Jerusalém, tratando com maior profundidade as origens da instituição e detalhes arquitetônicos levantados nas escavações arqueológicas de ruínas, tanto na Palestina como fora dela, revelando os ritos, a hierarquia e outros pormenores característicos desta instituição na antiguidade. Sinagogues of Europe: architecture, history, meaning de Carol Krinsky (1996) registra um estudo com grande riqueza de detalhes sobre as sinagogas do continente europeu. Seu panorama traz as sinagogas da Europa, organizadas geograficamente, desde a diáspora até a atualidade, abordando também as hipóteses sobre as origens da instituição, seu desenvolvimento histórico e sua liturgia.

Quanto a algumas questões importantes para a compreensão do universo das sinagogas e dos entendimentos sobre sua arquitetura na atualidade, o livro Jewish Identity on Architecture apresenta artigos de Samuel D. Gruber (2004), que trata da construção da identidade judaica ao longo dos séculos através dos projetos das sinagogas. Também o de Edward van Voolem (2004), que aborda as particularidades da cultura judaica advindas da sua condição de exílio e da constante tensão entre casa e diáspora. 
No tocante a alguns procedimentos adotados, há considerações importantes. Com o objetivo de dar maior compreensão da pesquisa a qualquer tipo de público, alguns detalhes relacionados à religião, língua e cultura hebraica foram suprimidos, bem como termos hebraicos relacionados a aspectos da sinagoga foram omitidos ou simplesmente traduzidos. Apesar de ser composta por diferentes segmentos, a lei judaica foi chamada simplesmente de "Lei Judaica". O Templo de Jerusalém existiu em dois momentos diferentes, o Templo de Salomão e posteriormente 0 de Herodes, denominados, durante o trabalho, apenas como "Templo de Jerusalém". A partir do período denominado "Ascensão do Cristianismo", a terminologia d.C. foi omitida por não parecer necessária a partir deste ponto. A datação dos edifícios foi feita com base no ano de finalização da obra. Quando o edifício foi construído e modificado em momentos diferentes, adotou-se o ano da conclusão da fase apresentada. 


\section{CAPÍTULO 1 - DEFINIÇÃO E ORIGENS}

\section{DEFINIÇÃO}

"Sinagoga" refere-se ao local de culto judaico. Seu propósito dividese em três funções principais: orações, estudo e encontros comunitários. Seu nome original no hebraico é beit knésset, que significa "local de assembléia". Seu equivalente no grego synagein, que significa "ajuntamento", foi quem deu origem ao termo em português. Apesar desta clara definição na atualidade, no passado ela foi chamada por diferentes nomes, pelos quais cada comunidade se referia ao seu local de reuniões, o que reflete as diferentes percepções da instituição e de seu lugar na sociedade (LEVINE, 2005). Em determinados momentos da história, a instituição vai assumir ênfases em diferentes aspectos, comunais, místicos, educacionais ou políticos. Seu estabelecimento se dá de maneira muito simples.

Apesar de sua diversidade de funções, a idéia central, na criação de uma sinagoga, está voltada mais ao conceito de comunidade, de forma que qualquer lugar onde se reúna um minian, o quorum mínimo de dez homens judeus adultos, pode servir como sinagoga. Assim, sem um minian, não poderão ser realizadas certas liturgias sem a presença deste quorum. Dessa forma, é este quorum, e não o edifício em si, o que constitui uma sinagoga. Um grupo de homens de negócio pode, por conta própria, iniciar uma sinagoga que funcionará no horário que Ihes for mais conveniente. Um homem que deseja orar com pessoas de sua comunidade local pode estabelecer uma sinagoga.

A sinagoga pode ser composta apenas do salão de orações ou de outras instalações como salas de estudo, alojamentos, cozinhas, centros comunitários, etc. Isto pode mudar conforme a época, condições financeiras e tolerância religiosa da sociedade majoritária. Elas podem ser comparadas a edifícios da fé cristã em vários aspectos. Com a simples remoção da bimah ${ }^{6}$ e instalação de um altar, ela pode ser transformada em uma igreja, como na sinagoga "Santa Maria la Blanca" em Toledo (fig.5), na Espanha, confiscada e transformada em igreja em 1420. Como o cristianismo vem a nascer em meio ao judaísmo, a nova religião

\footnotetext{
${ }^{6}$ Bimah é uma plataforma, normalmente elevada, de onde são lidas as escrituras sagradas, evento que possui lugar central no serviço da sinagoga.
} 
acabou adaptando várias ideias da sinagoga. As igrejas antigas também eram centros comunitários com pátios e salões para encontro e escolas paroquiais.

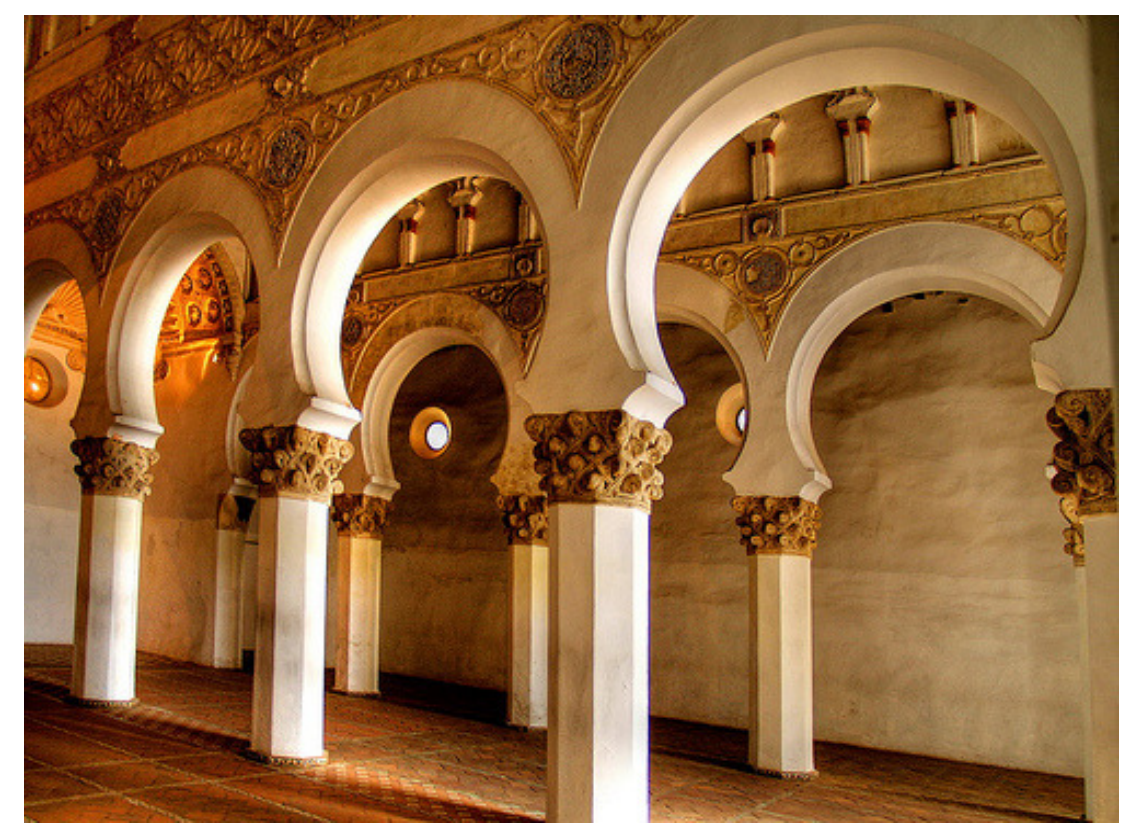

Figura 5: Interior da sinagoga Santa Maria la Blanca, em Toledo, Espanha. <http://farm1.static.flickr.com/172/440520487_001bf3f456.jpg> Acesso em: 04 jan. 2011.

Apesar de similaridades físicas e funcionais, as igrejas diferem das sinagogas em muitos aspectos. A divisão da população judaica local é dividida em várias congregações, o que tende a manter seus edifícios menores e mais modestamente decorados do que as igrejas, que são construídas com os fundos de toda uma comunidade ou diocese ${ }^{7}$. Também diferentemente de outras religiões, um aspecto essencial da fé judaica é que ela pode ser expressa nos aspectos cotidianos da vida. Sendo assim, um judeu pode vivenciar sua fé na sua plenitude, mesmo que não possa frequentar uma sinagoga.

\footnotetext{
${ }^{7}$ Diocese é uma unidade geográfica administrativa da Igreja Católica Romana coordenada por um bispo.
} 


\section{O TABERNÁCULO E O TEMPLO DE JERUSALÉM}

Entre o nono e segundo séculos a.C., os judeus adoravam em templos sacrificiais onde se ofereciam produtos da terra e animais. O primeiro templo deste tipo foi o Tabernáculo de Moisés (fig.6) que, juntamente com seu substituto, o Templo de Jerusalém (fig.8), tornou-se arquétipo para as diversas gerações de sinagogas e igrejas. O Tabernáculo foi construído mediante uma ordenança divina, pouco depois que os hebreus saíram do Egito, sob a liderança de um homem chamado Moisés. Depois de lá permaneceram durante quatrocentos
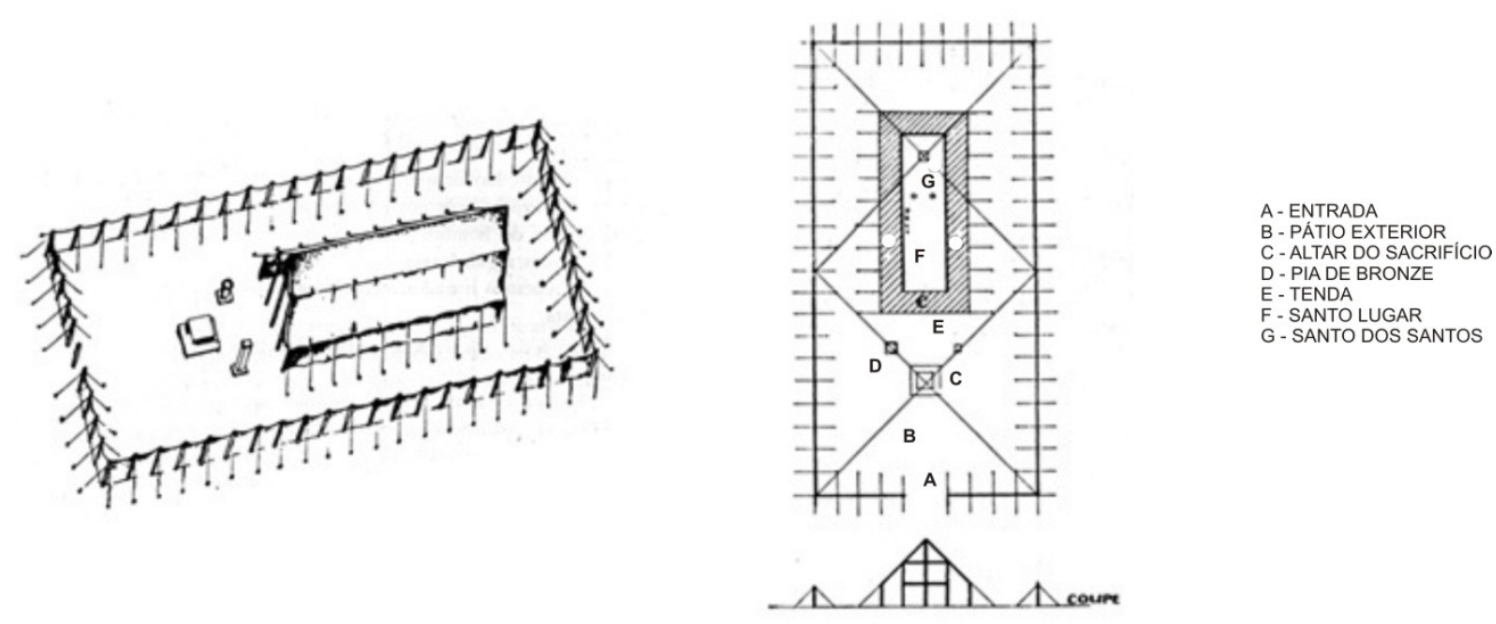

Figura 6: Desenhos do Tabernáculo de Moisés de autoria de Le Corbusier (legenda do autor). Fonte: CORBUSIER, 1973, p.46.

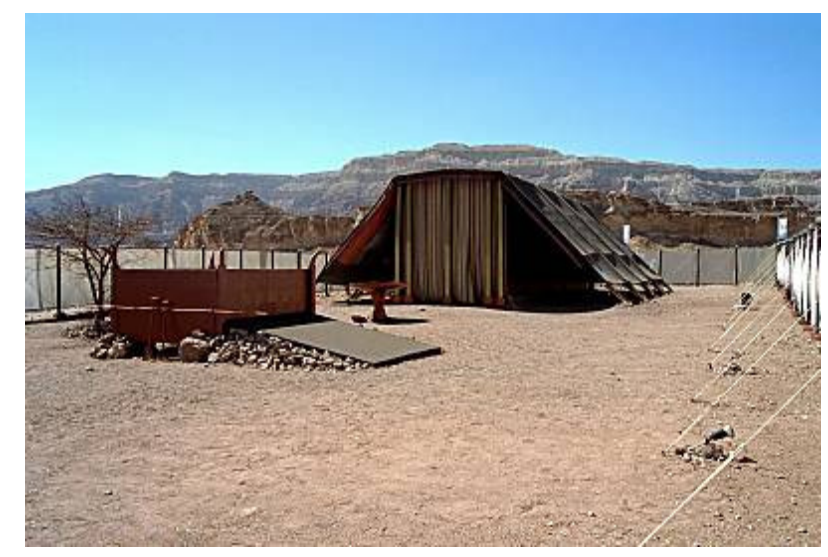

Figura 7: Réplica em tamanho real do Tabernáculo de Moisés no Neguev, Israel. Fonte: $<$ http://www.bibleplaces.com/images/Tabernacle with altar 129-09tb.jpg > Acesso em: 04 jan. 2010. 
anos como escravos, peregrinaram pelo deserto do Sinai durante quarenta anos, aguardando pela promessa divina da terra de Canaã ${ }^{8}$. Essa tenda sacrificial foi executada sob orientação divina, de forma que pudesse ser montada e desmontada conforme os hebreus se deslocassem pelo deserto. O serviço tanto no Tabernáculo, como no Templo só podia ser realizado por um grupo de sacerdotes separados especialmente para este fim. Sua seleção era hereditária, mais especificamente de uma das doze tribos de Israel $^{9}$, a tribo de Levi. Os chamados levitas, membros desta tribo, serviam no Tabernáculo ou no Templo em turnos organizados. Havia ainda a figura do Sumo Sacerdote, que uma vez por ano entrava no Santo dos Santos por ocasião do Yom Kippur ${ }^{10}$, o dia do perdão para apresentar sacrifícios, um sacrifício anual. O calendário judaico é composto de um ciclo anual de festas, além do Shabat $^{11}$ e das luas novas, quando deveriam ser apresentados sacrifícios específicos no templo, além dos sacrifícios diários e das ofertas.

A descrição do Tabernáculo é feita com detalhes no livro de Shemot ou $\hat{E}_{x o d o}{ }^{12}$, inclusive de suas proporções como apresenta o esquema dado por Le Corbusier (fig.6). Ele constituía-se de uma tenda retangular de tecido delimitada por um acortinado. Nela é possível encontrar elementos posteriormente adotados nas sinagogas e igrejas cristãs. Entre eles estão a pia de bronze onde os sacerdotes lavavam os pés e as mãos antes de adentrarem à tenda para ministrar.

Ainda hoje algumas sinagogas possuem uma pia em seu vestíbulo com o propósito de purificação, antes de entrar no salão de orações. O próprio vestíbulo da sinagoga também remonta às escalas de santidade do Tabernáculo e do Templo, passando inicialmente pelo pátio exterior, depois pelo Santo Lugar, chegando por fim ao Santo dos Santos onde repousava a Arca da Aliança ${ }^{13}$.

${ }^{8}$ Canaã é a terra que Deus prometeu aos hebreus por intermédio de Moisés como garantia de sua saída do Egito. Atualmente, Canaã corresponde a parte do que hoje é o território do estado de Israel.

${ }^{9}$ Israel é o nome dado por Deus a Jacó, filho de Isaque, filho de Abraão, patriarcas do povo hebreu. Jacó, posteriormente Israel, empresta seu nome ao povo de sua descendência, cujas doze tribos também recebem o nome de seus doze filhos. De um destes doze filhos, Judá é que vem a denominação "judeu".

10 Yom Kippur, "Dia do Perdão" é uma das celebrações do calendário judaico. Neste dia toda a nação jejua em demonstração de arrependimento pelos pecados, enquanto o Sumo Sacerdote realiza sacrifícios substitutivos.

${ }^{11}$ O Shabat corresponde ao sábado ocidental, o sétimo dia da criação, quando, por ordenação divina, nenhum tipo de trabalho deve ser realizado.

12 Éxodo, ou Shemot, em hebraico transliterado, é o segundo livro da Torah, que corresponde ao Pentateuco, os primeiros cinco livros da bíblia cristã.

${ }^{13}$ A Arca da Aliança, como o nome já explica, era uma arca confeccionada em madeira e revestida de ouro onde ficavam guardadas as pedras com a gravação dos dez mandamentos que Deus entregou a Moisés e a Israel. Sobre a arca havia dois querubins de ouro, exato lugar onde Deus manifestava sua presença. 
Conforme se avançava às câmaras interiores, o grau de santidade ia aumentando devido à presença de Deus. No Santo lugar ficavam elementos do culto como a menorah $^{14}$ (fig.9) e a cortina que o separava do Santo dos Santos.

Nas sinagogas também pode encontrar a presença do pátio exterior em referência ao Tabernáculo e ao Templo, local importante para comportar a realização das festas anuais. São diversas as analogias que podem ser feitas entre o Templo, o Tabernáculo e as sinagogas.

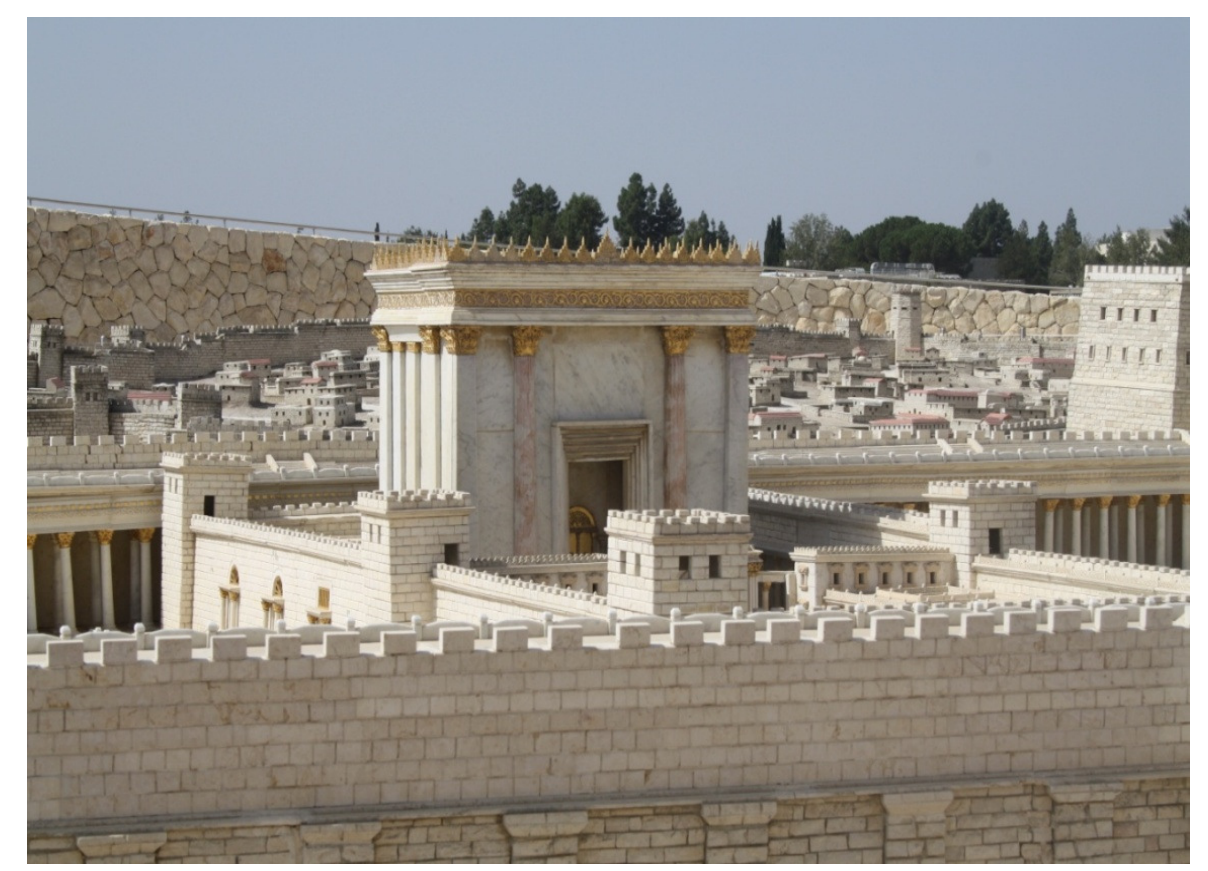

Figura 8: Modelo do Templo de Herodes, construído para substituir o Templo de Salomão, em exposição permanente no Museu de Israel, Jerusalém, Israel. Foto: Sergio Rugik Gomes.

${ }^{14}$ A Menorah é um candelabro de sete braços, alimentado por azeite, feito de uma peça só de ouro puro. Um dos símbolos do estado de Israel. 


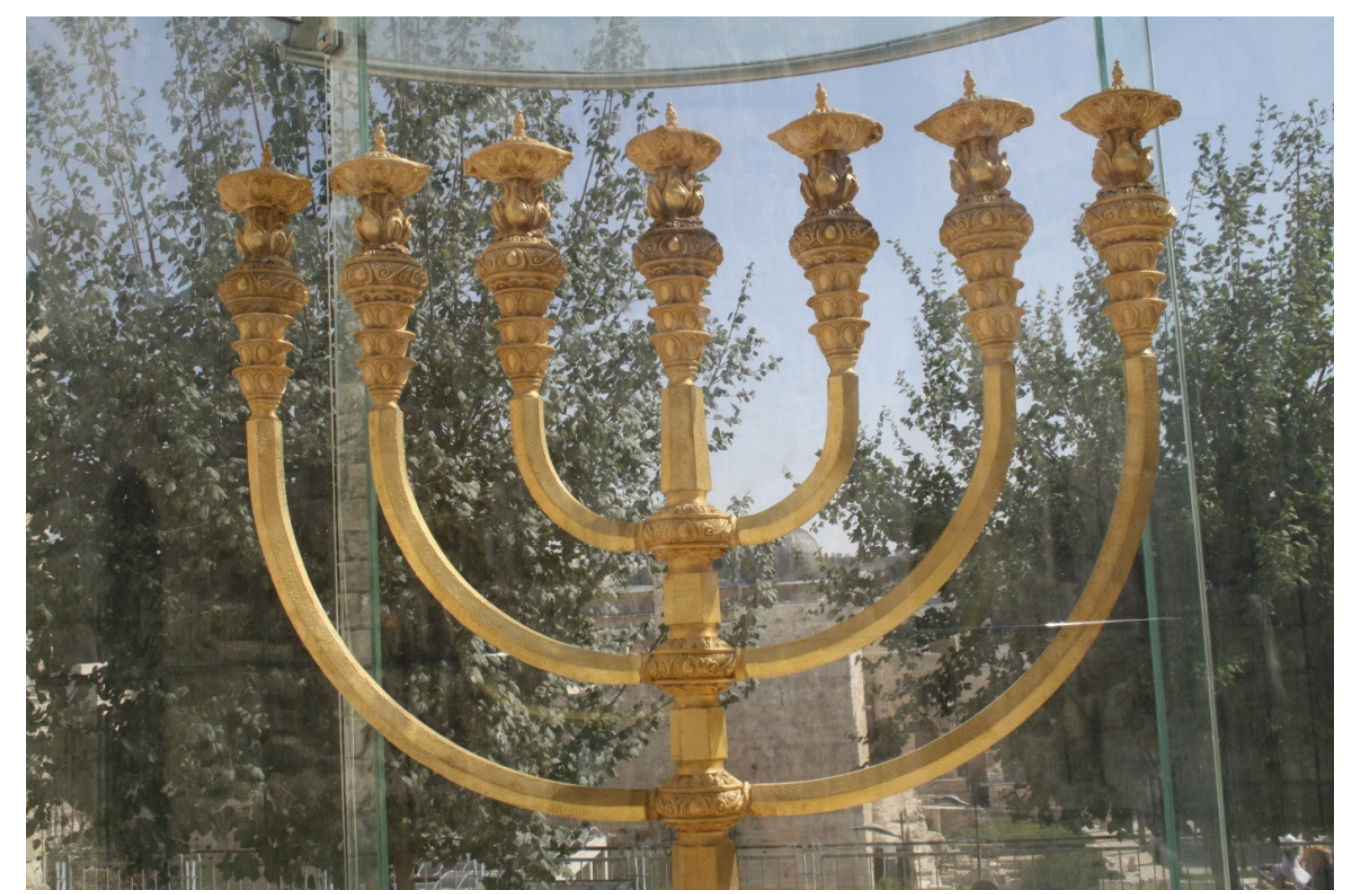

Figura 9: Menorah em exposição no bairro judeu em Jerusalém. Foto: Sergio Rugik Gomes.

Quanto ao Templo de Jerusalém, apesar de sua destruição ter ocorrido há quase dois mil anos, seu tema é bastante atual. Grupos religiosos e políticos em Israel têm discutido sua reconstrução ao lado de uma mesquita, o Domo da Rocha, sítio de grande valor sagrado para os muçulmanos. Ele aparece em dois momentos da história de Israel. Seu primeiro edifício foi construído pelo Rei Salomão por volta do século décimo a.C., e destruído pelos Babilônios em 586 a.C. O segundo edifício teve sua construção iniciada em 538 a.C. no mesmo local do Primeiro Templo, tendo sido por fim destruído em 70 d.C. Ele era central no estilo de vida dos judeus por causa do ciclo anual de festas, quando toda a nação ia à Jerusalém para as celebrações, por causa do sistema sacrificial, onde uma série de sacrifícios eram exigidos como remissão de pecados e como sistema judiciário, tendo os sacerdotes funcionando como juízes de diversas questões.

Além disso, o Templo também era um centro de ensino da Torah ${ }^{15}$, onde eram feitas leituras das escrituras. Sua organização segue a mesma sequência do Tabernáculo, e nele estão presentes os mesmos elementos de culto como a pia de bronze e o altar para os sacrifícios. No pátio, onde se localizava o altar, não era permitido $o$ acesso às mulheres, que podiam chegar apenas ao pátio anterior a este.

\footnotetext{
${ }^{15}$ Torah é o nome dado ao pergaminho contendo os cinco primeiros livros do Tanah, o equivalente ao Antigo Testamento da Bíblia cristã. Sua leitura tem lugar central no serviço religioso na sinagoga.
} 
Herodian Temple: Holy of Holies over Dome of Tablets (Asher S. Kaufman's view, 1983 AD)

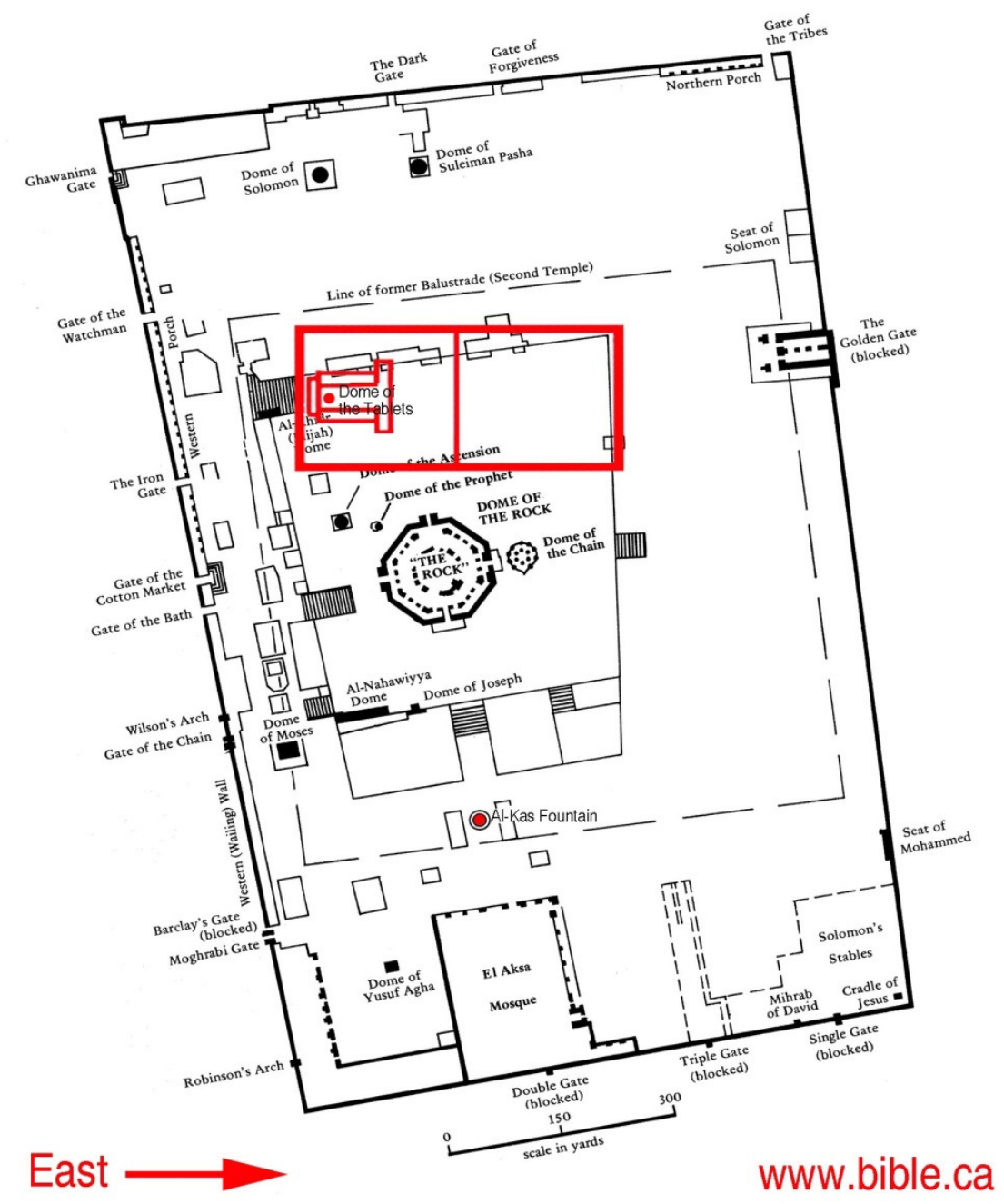

Figura 10: Planta atual do monte do Templo com sua possível antiga localização. <http://www.bible.ca/archeology/bible-archeology-jerusalem-temple-mount-dome-of-tablets.htm> Acesso em: 05 jan. 2011. 


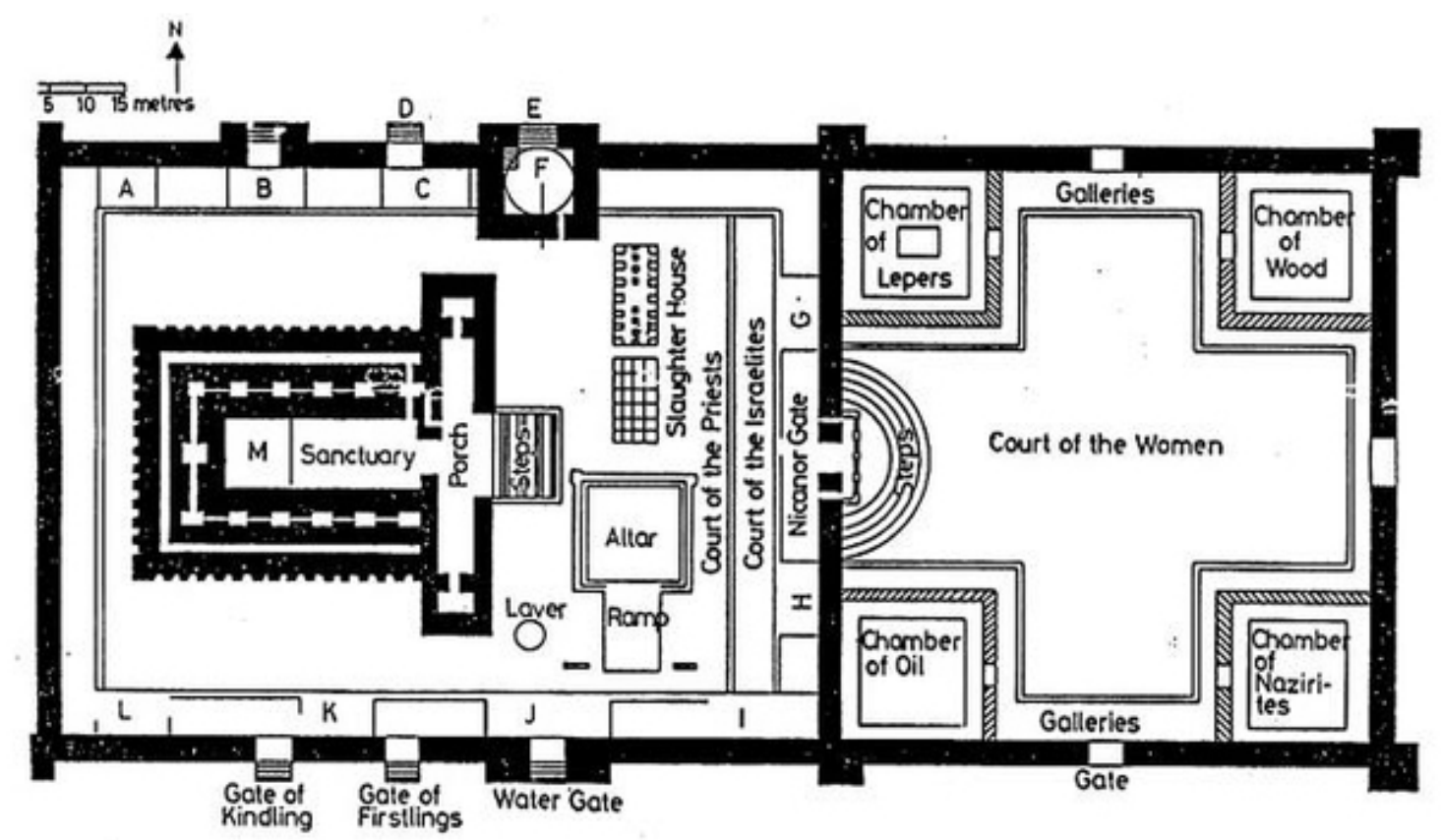

Figura 11: Reconstituição da planta do Templo de Jerusalém. <http://www.sacreddestinations.com/israel/images/jerusalem/temple-mount/resized/herod-temple-floor-plan-nc-augedu.jpg > Acesso em: 05 jan. 2011.

Quando o Templo é destruído, há uma profunda mudança na forma de se viver o judaísmo, pois com ele também cessam os sacrifícios e os turnos sacerdotais. Além de fortalecer a instituição, a ausência do Templo vai atribuir à sinagoga um novo papel dentro do contexto judaico, com novos significados e novas formas de uso. Parsons (2010, p. 1 - trad. nossa) afirma que:

É importante compreender que a destruição do templo em 70 d.C. causou um movimento catastrófico para o povo judeu. Como poderiam os sábios entender o judaísmo e praticar sua fé separados dos rituais e sacrifícios oferecidos pelo serviço sacerdotal? Com o desaparecimento do templo quem seriam as autoridades religiosas do povo judeu?

É a partir desse momento que os pensadores do judaísmo começam a discutir as novas formas de se vivenciar a religião. O judaísmo vem a se tornar uma prática congregacional, mais do que uma hierarquia com um poder centralizado. Regras sobre os sacrifícios são recitadas na sinagoga como uma forma menor de se cumprir os mandamentos que não puderam mais ser cumpridos na ausência do templo, assim como orações oferecidas nos horários correspondentes aos sacrifícios. A própria separação entre homens e mulheres no Templo passa a ser uma regra dentro da sinagoga. As relações entre Templo e sinagoga são expressas mais em seu uso do que em sua forma exterior. 
O Templo servia a toda a nação, enquanto a sinagoga serve apenas a uma comunidade local, ou até mesmo a uma propriedade privada. O Templo era revestido de maior santidade, tendo sido instituído pelo próprio Deus. A sinagoga está sujeita a condicionantes humanas e terrenas, como o design, a ortodoxia do rito adotado e a escolha dos materiais utilizados. A santidade do Templo era permanente, de forma que jamais poderia ser vendido ou utilizado para qualquer outra finalidade. A sinagoga pode ser vendida ou mudar-se para outro lugar, pois está ligada às atividades nelas desenvolvidas e não ao edifício.

O ritual no templo normalmente enfatizava serviços sacrificiais, que se desenvolviam do lado de fora, normalmente realizados por membros de uma classe sacerdotal. Na sinagoga, entretanto, os serviços devem conter uma congregação, seu culto é interno e não exige a condução de um sacerdote ordenado ou consagrado, mas conduzido por um membro de renome na congregação e posteriormente por um cantor, enquanto o rabino ${ }^{16}$ é responsável pela educação e pela exegese textual ou legal. A ordenação rabínica apenas indica que a pessoa foi graduada por um seminário teológico, diferente do que representa a consagração de um sacerdote. Qualquer judeu com o estudo necessário pode vir a se tornar um rabino ou cantor, diferentemente dos sacerdotes do templo que só poderiam ser escolhidos a partir de uma linhagem hereditária.

Apesar de a sinagoga ter experimentado seu crescimento a partir da destruição do Templo, sua existência já pode ser comprovada antes deste período. Entretanto as opiniões quanto às origens da instituição são diversas e distintas. Levine (2005) afirma que "é apenas no primeiro século d.C. que a sinagoga surge sob a plena luz da história como a instituição comunal central das comunidades judaicas através da Judeia e da diáspora." As fontes disponíveis que testemunharam o surgimento da sinagoga como instituição, já não contêm mais em si as informações sobre quando estas surgiram, quais fatores foram decisivos em seu desenvolvimento, ou quando exatamente isto se deu. Talvez essas informações não pareciam merecer comentários ou registros em seu estágio formativo. A evidência textual mais antiga da existência de uma sinagoga aparece num conjunto de escritos do Egito Ptolomaico ${ }^{17}$ do terceiro século a.C., que menciona um proseuche, um local

\footnotetext{
${ }^{16}$ Rabino significava "mestre" ou "professor". Seu papel na sinagoga está mais ligado ao ensino das escrituras.

${ }^{17}$ Período do antigo Egito de 305 a.C. a 30 a.C. sob domínio do general romano Ptolomeu.
} 
aberto, normalmente próximo a águas correntes, onde os judeus se reuniam para orar.

As ruínas arqueológicas mais antigas são as de Delos $^{18}$ cuja construção pode ser datada do segundo ou primeiro século a.C. Entretanto, nesta época, as cidades maiores, como Alexandria, Roma e Antioquia ${ }^{19}$, já ostentavam um número razoável de sinagogas e as demais cidades e vilas do império romano tinham pelo menos uma. Outra hipótese situa o surgimento da sinagoga por volta de 586 a.C., quando os babilônios invadem Jerusalém e destroem o Templo, carregando muitos cativos para o vale do Eufrates. Para substituir a perda do Templo, os judeus no exílio estabeleceram santuários sacrificiais onde provavelmente mantinham encontros comunitários. Mesmo quando permitidos a retornar a sua terra natal, no final do século seis a.C., ainda que com a reconstrução do templo, é possível que tenham sido mantidos os encontros comunitários fora do templo.

Uma hipótese moderna e controversa localiza a origem da sinagoga como um edifício para reuniões religiosas em um período pós Hasmoneano ${ }^{20}$. No tempo dos fariseus - estudiosos que não faziam parte do centro de poder sacerdotal do Templo, tornaram-se de certa forma rivais dos sacerdotes. Enquanto os sacerdotes tinham como base de seu ofício o sistema sacrifícial, no sistema farisaico o objetivo principal de sua doutrina baseava-se na salvação da alma na era messiânica, alcançada através da observação de um código de leis, com uma vertente escrita e outra oral, divinamente reveladas.

A explicação da lei e as leituras, tanto do Pentateuco como dos profetas, requeriam locais de encontro, os quais podem ter se desenvolvido em sinagogas com a função dupla de local de encontro e de orações.

\footnotetext{
${ }_{19}^{18}$ Delos é uma pequena ilha do Mar Egeu, onde foram encontradas as ruínas de uma sinagoga.

19 Antioquia foi uma importante cidade da antiguidade onde atualmente na Turquia, por sua proximidade à Palestina, recebia um grande número de judeus.

$20 \mathrm{O}$ período Hasmoneano corresponde a um estado judaico independente estabelecido entre 140 a.C., e 37 a.C. sob o comando de Simão Macabeu.
} 


\section{LITURGIA}

Para a compreensão da utilização do espaço da sinagoga, é importante a clarificação de alguns elementos relacionados à liturgia. Dentre eles pode-se citar a arca onde são guardados os pergaminhos sagrados, a bimah, de onde é feita a leitura dos textos, a orientação do edifício, seu vestíbulo ou ainda as ordenanças do Talmud, a lei oral judaica. O serviço litúrgico na sinagoga se desenrola numa combinação entre a leitura sistemática dos textos sagrados e as orações da comunidade. Apesar de serem comuns à maior parte das sinagogas, as formas de utilização destes elementos e sua organização no espaço podem variar conforme o rito da comunidade, sua localização geográfica, ou podem até mesmo não existir dependendo da época.

\subsection{Talmud}

O Talmud é o resultado da junção de tratados de sábios judeus sobre a tradição oral e sua interpretação. Nele são estabelecidas algumas das relações entre o Templo de Jerusalém e a sinagoga, entretanto sem mencionar forma ou estilo, apenas em aspectos funcionais. Segundo o Talmud, o fiel deve estar voltado para Jerusalém ao recitar determinadas bênçãos prescritas em referência aos escritos do livro do profeta Daniel ${ }^{21}$, no capítulo 6, verso 10. E assim como o profeta Daniel tinha as janelas de seu quarto voltadas para Jerusalém, a sinagoga também as deve ter.

Daniel, pois, quando soube que a escritura estava assinada, entrou em sua casa e, em cima, no seu quarto, onde havia janelas abertas do lado de Jerusalém, três vezes por dia, se punha de joelhos, e orava, e dava graças, diante do seu Deus, como costumava fazer BÍBLIA HEBRAICA, Daniel, $6: 10)$.

O Talmud também interpreta da Torah alusões quanto à altura dos edifícios, como no livro de Provérbios, Bíblia Sagrada, capítulo 1, verso 21, "do alto dos muros clama, à entrada das portas e nas cidades profere as suas palavras", de

${ }^{21}$ Daniel foi um dos profetas da história do povo judeu. Os profetas tinham papel fundamental na liderança da nação de Israel, trazendo direcionamento ao povo da parte de Deus. 
forma que as sinagogas devem ser mais altas que as outras edificações ao seu redor, estando assim localizada em um sítio mais elevado.

Segundo Krinsky (1996) o Talmud se refere ao homem descendo diante da arca e da Torah. Dada essa interpretação, muitas sinagogas organizaram os níveis dos pisos internos de forma que a arca ficasse erguida em relação aos fiéis. Os escritores talmúdicos tratam ainda das atividades que podem ser realizadas dentro da sinagoga. Inicialmente ela pode ser considerada na mesma condição de uma casa. Assim como um homem se oporia a sua casa ser utilizada como local de passagem, o mesmo se dá com a sinagoga. Pessoas, envolvidas em uma discussão sobre a lei, poderiam se abrigar em uma sinagoga durante uma tempestade para continuar sua busca piedosa, caso contrário a sinagoga não poderia ser usada como abrigo contra o calor ou a chuva.

Além disso, os objetos e edifícios sagrados podem apenas crescer em santidade, mas nunca descrescer. Uma sinagoga, por exemplo, poderia ser transformada em casa de estudo, mas nunca se tornar uma sinagoga novamente. Uma sinagoga só poderia ser vendida se o lucro obtido fosse utilizado para a compra de uma bimah ou de uma arca, objetos sagrados do culto. Se uma bimah fosse vendida, o dinheiro só poderia ser usado para comprar uma capa para os rolos da Torah. Se a capa fosse vendida, a renda só poderia ser utilizada para a própria Torah, o objeto mais sagrado de todos.

Para algumas autoridades judaicas, a santidade do edifício diminui no momento em que o minian deixa de realizar atividades que conferem santidade ao local. Por isso, se vendida, a sinagoga pode novamente ser readquirida para voltar a ser uma sinagoga. Ela poderia ser vendida para um propósito secular se a renda obtida fosse revertida para a aquisição de outra sinagoga ou outro uso sagrado. Entretanto ela nunca poderia ser vendida para usos impuros ${ }^{22}$. Até as ruínas de uma sinagoga deveriam permanecer de preferência intocáveis e cobertas de vegetação, para despertar compaixão.

\subsection{A Arca}

22 A lei judaica separa certos elementos como puros e impuros, dentro de um código de condutas que devem ser observados para a purificação. 
A arca tem a função de abrigar os pergaminhos da Torah fig 15, o objeto mais sagrado dentro de uma sinagoga, que fica encoberta por um tecido e é normalmente adornada com um escudo de prata (fig. 13). A Torah contém os relatos sobre a criação, a história dos patriarcas e do povo judeu e a lei outorgada por Deus e corresponde ao Pentateuco da bíblia cristã. Por si só, a Torah é mais sagrada que o próprio edifício da sinagoga. Pela importância que os pergaminhos representam, à arca cumpre a função de garantir a preservação da lei. Por questões de segurança, ela é confeccionada em um material rígido, normalmente madeira, entretanto, ao longo da história, a arca foi construída de diferentes formas. Em seus adornos exteriores, ela pode evocar aspectos de edifícios da terra santa, em uma tentativa de aproximar sua forma da forma do templo.

Como já mencionado, a própria arca é uma referência à Arca da Aliança presente no Tabernáculo e posteriormente no Templo de Jerusalém, onde estavam contidas as tábuas da lei escritas pelo próprio Deus. Na sinagoga, uma cortina protege a Torah dentro da arca, assim como a cortina que separava o Santo dos Santos do Santo Lugar no Tabernáculo e no Templo. A arca tem função simbólica, enquanto que a bimah tem maior importância funcional.

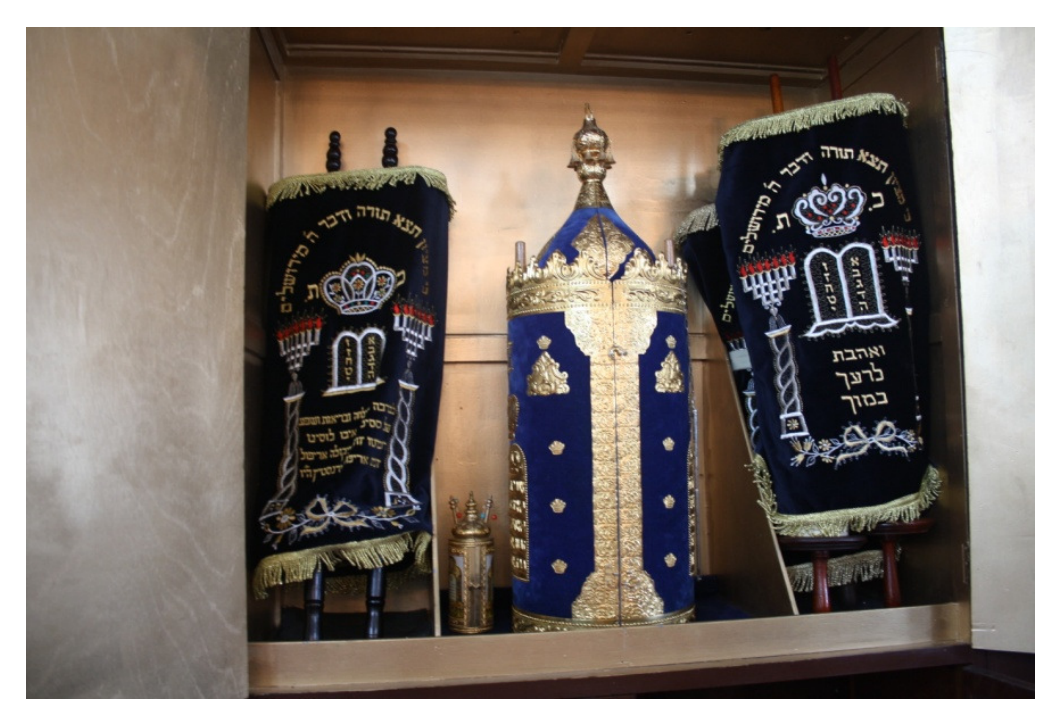

Figura 12: Rolos da Torah e escudo no interior da arca da sinagoga askenazita de Santos.Foto: Sergio Rugik Gomes. 


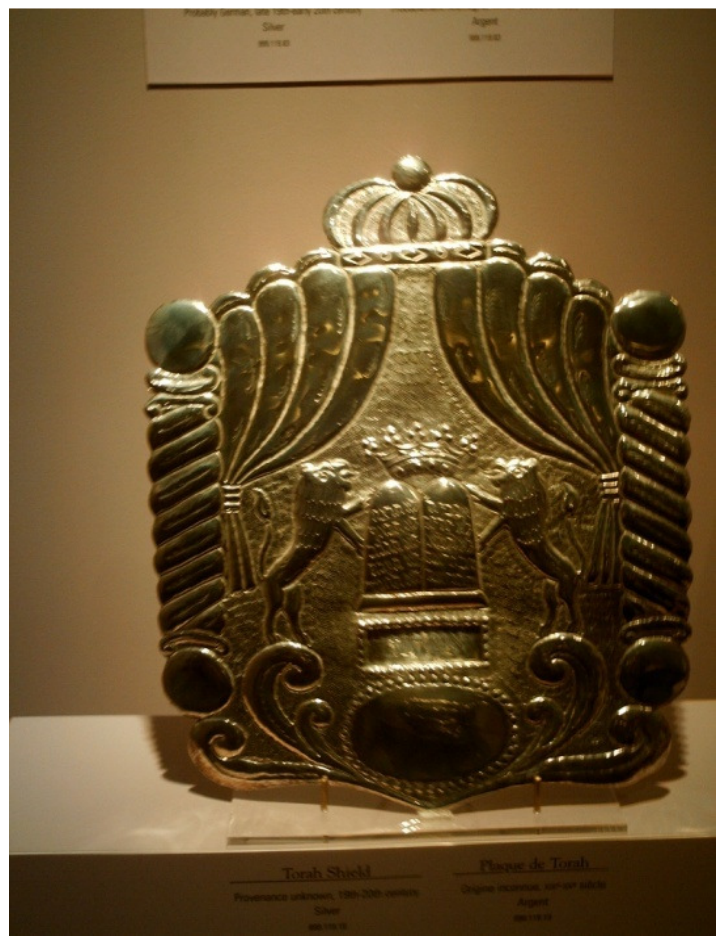

Figura 13: Escudo de prata para adorno da Torah em exposição no Metropolitam Museum de Toronto, Canadá. Foto: Sergio Rugik Gomes.

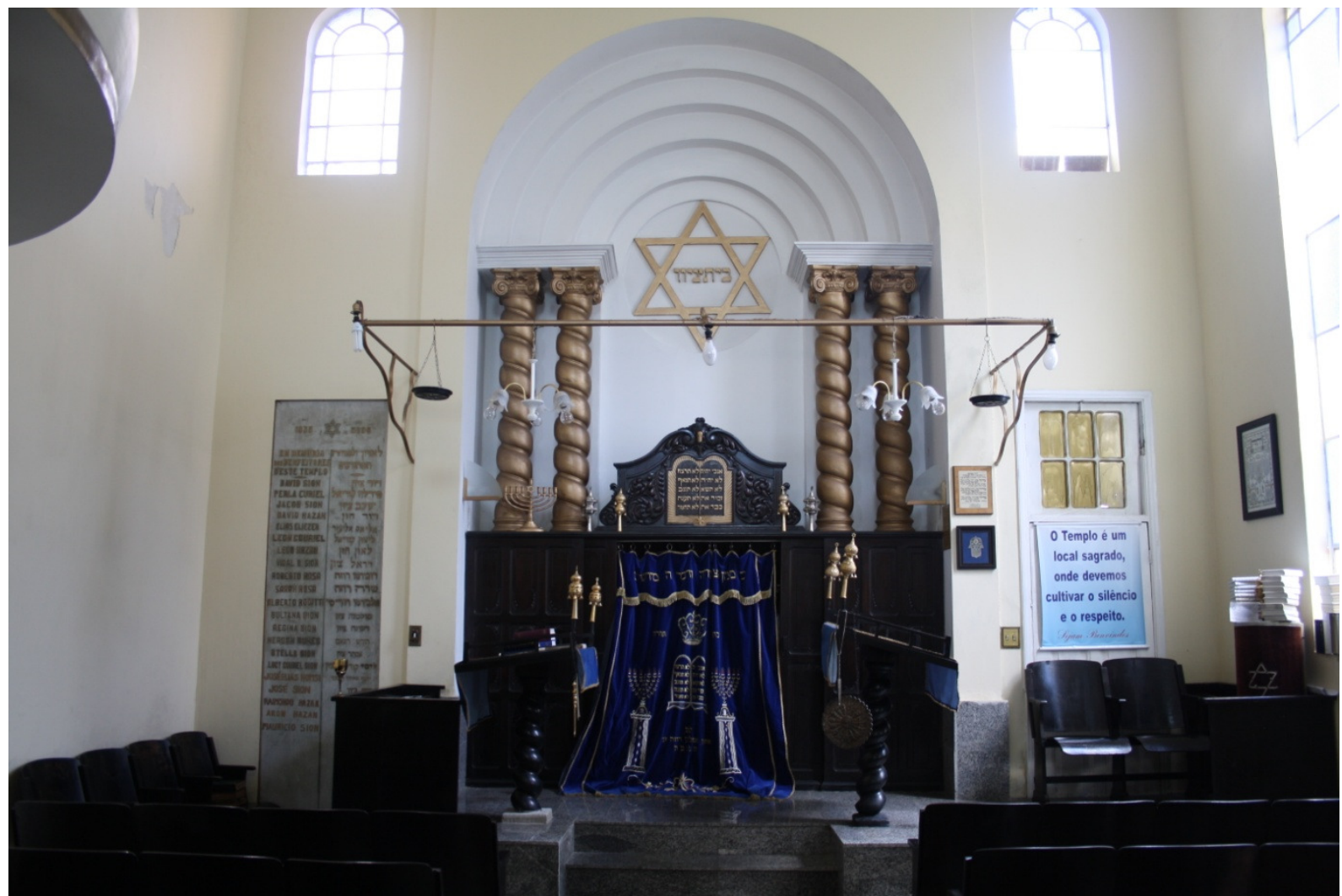

Figura 14: Vista da arca e bimah juntas na Sinagoga Beit Sion em Santos. Foto: Sergio Rugik Gomes. 


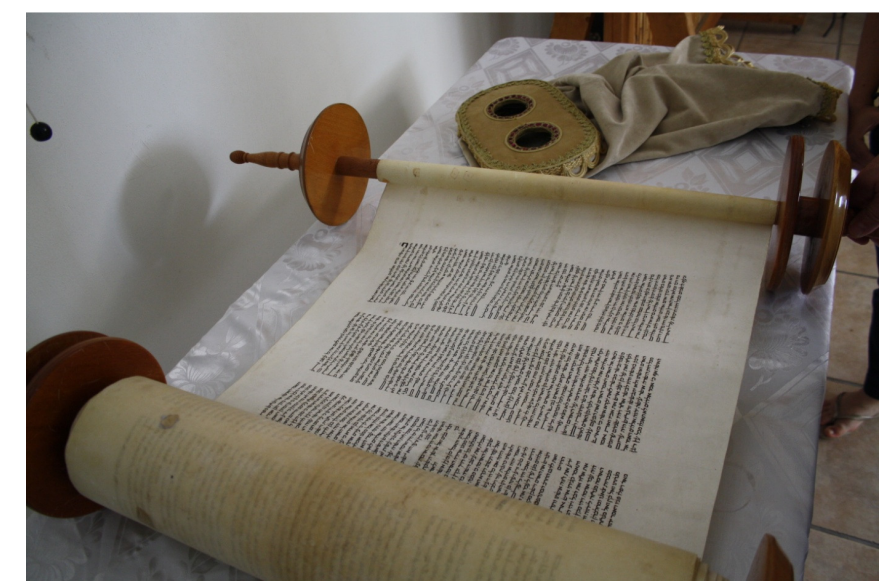

Figura 15: Pergaminho da Torah aberta em mesa na sinagoga de Kiriat Yam, Israel Foto: Sergio Rugik Gomes

\subsection{A Bimah}

Durante o serviço na sinagoga, depois de retirada da arca, a Torah é aberta e lida sobre a bimah, uma mesa normalmente de madeira e elevada sobre uma plataforma, de onde o oficiante lê dos rolos da Torah e lidera a congregação ao voltar-se para Jerusalém ${ }^{23}$ durante as orações. Ela é o primeiro foco de atenção, enfatizada por seu design, localização e pela luz, que frequentemente é mais intensa ao redor dela. Ela é o elemento que mais vai influenciar a planta de uma sinagoga.

De forma geral, nas sinagogas de rito sefaradita ${ }^{24}$, ela aparece no extremo oposto do longo eixo da arca, nas asquenazitas ${ }^{25}$ ela é colocada próxima ao centro do salão de oração. Entretanto, assim como a arca, sua forma e seu lugar na distribuição interna vão mudar conforme a época e a região. Ela pode possuir uma cerca e cobertura de madeira ou ferro, ou ainda estar evolvida pelos apoios centrais de uma cobertura abobadada. Na maioria das vezes, a bimah está disposta no eixo principal da sinagoga, frequentemente enfatizada por uma característica arquitetônica, como uma claraboia, brecha de luz no teto ou pilares laterais.

\footnotetext{
23 Jerusalém é a cidade sagrada para os judeus e atual capital do estado de Israel. Sobre ela estava edificado o antigo Templo, no local escolhido por determinação de Deus.

${ }^{24}$ Sefaraditas é a designação dada aos judeus originários da península ibérica.

${ }^{25}$ Ashquenazitas é a designação dada aos judeus originários do leste europeu.
} 


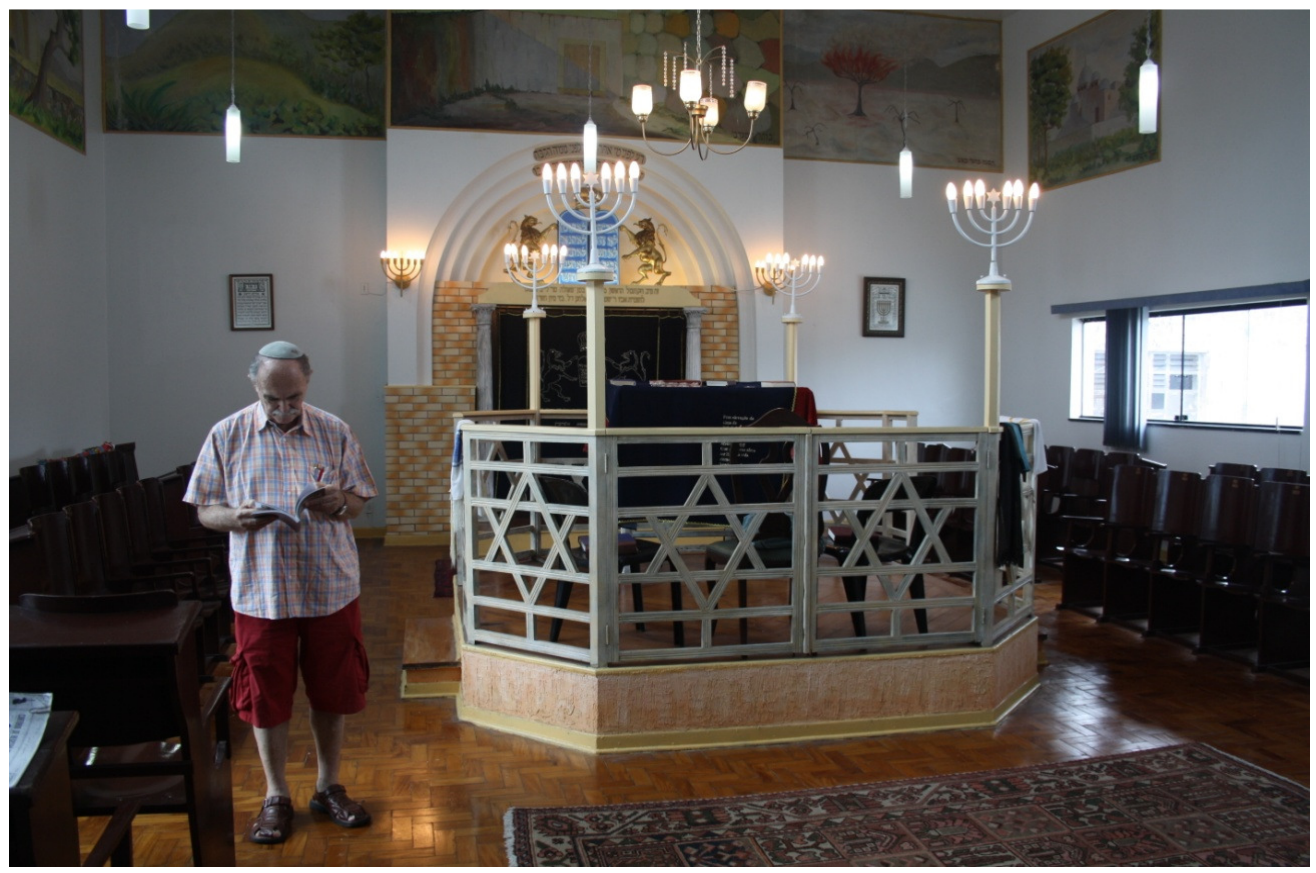

Figura 16: Plataforma de leitura (bimah) com a arca ao fundo na sinagoga Beit Jacob em Santos. Foto: Sergio Rugik Gomes

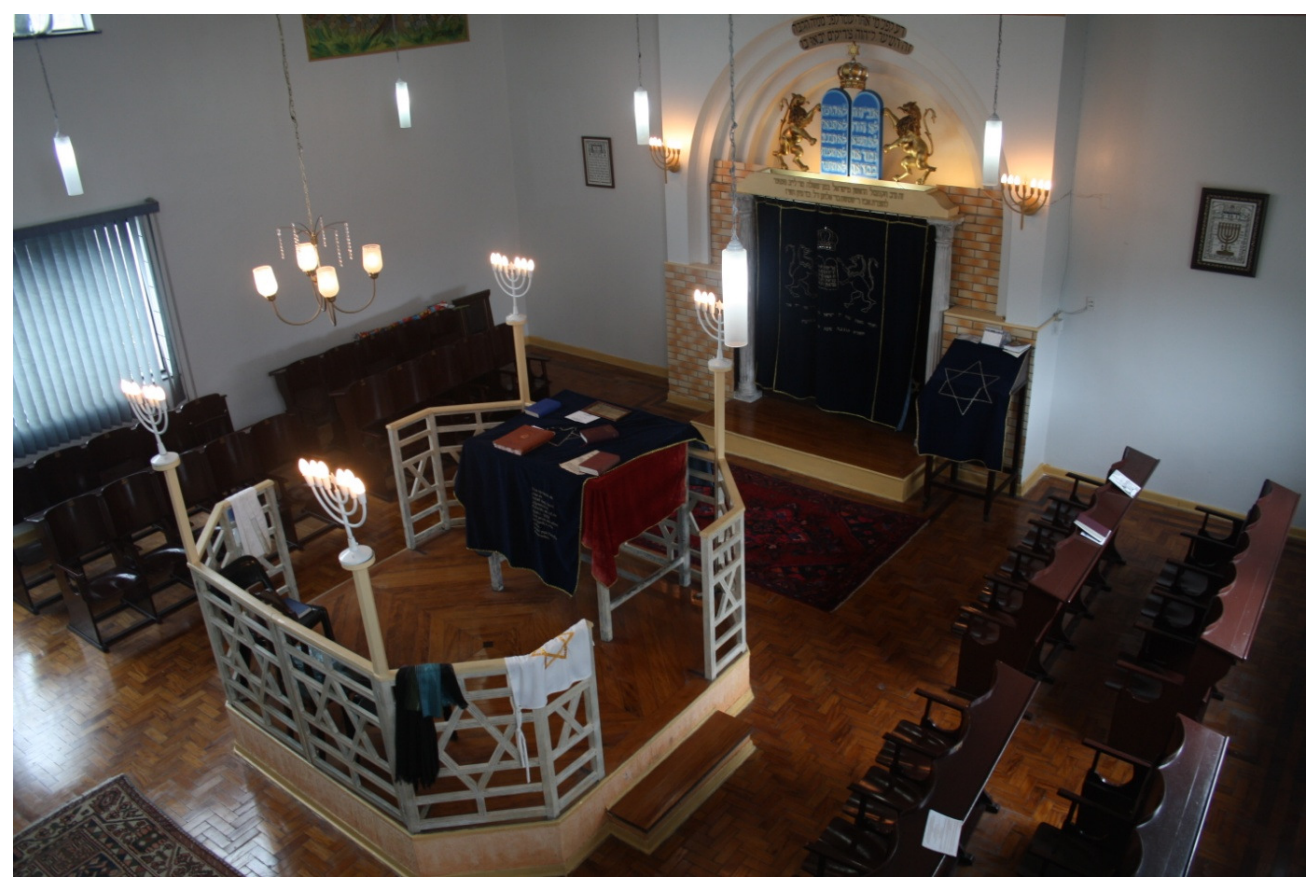

Figura 17: Vista da arca e bimah na sinagoga Beit Jacob em Santos. Foto: Sergio Rugik Gomes.

\subsection{Orientação do Edifício}

Um dos aspectos da sinagoga que vai sofrer mutações ligadas às transformações nas hierarquias de valores sociais e suas respectivas operações formais é a relação entre arca e bimah. A arca é o elemento da sinagoga revestido 
de maior santidade, uma referência à arca da aliança presente no templo de Jerusalém. A bimah é a plataforma em que o oficiante abre as escrituras para lê-las. O serviço litúrgico na sinagoga se desenrola numa combinação entre a leitura sistemática da Torah e as orações da comunidade. É a relação entre a arca e a bimah que vai definir a dinâmica espacial da liturgia, cujos pergaminhos transitam de um ponto a outro, sendo o principal elemento de ligação. A bimah, como local de instrução, compete com a arca que encerra o eixo que faceia Jerusalém, direção à qual são dirigidas as orações. A arca tem importância simbólica, enquanto a bimah é foco de orientação funcional.

Como a lei oral rege que as orações devem ser voltadas à Jerusalém, é mais comum que as sinagogas estejam voltadas para o leste, com a arca no extremo leste e a bimah vai estar disposta no eixo leste-oeste, no centro, no extremo oeste ou junto da arca, também dependendo da época e do local. De certa maneira é difícil evitar uma competição entre a bimah e a arca. As plantas resultantes da organização desses dois elementos vão acabar valorizando mais uma do que a outra.

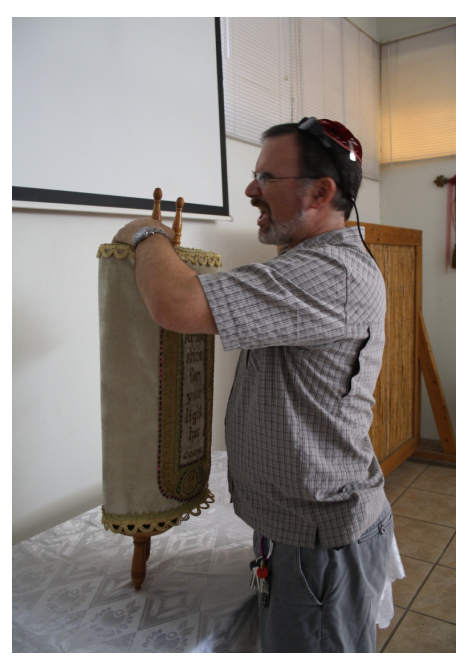

Figura 18: Judeu recitando a benção antes da leitura da Torah. Foto: Sergio Rugik Gomes.

\subsection{Pátio e Vestíbulo}

Depois do salão principal, o espaço mais importante de uma sinagoga é seu vestíbulo. Como no Templo de Jerusalém, ele cumpre a função de espaço intermediário entre o mundo exterior e o ambiente sagrado. É muito raro encontrar uma sinagoga cuja entrada seja diretamente ligada à rua ou ao pátio. Esse 
papel pode ser cumprido ainda por um biombo junto a entrada, pátio ou varanda. Nele é comum a instalação de uma fonte de água para fins de purificação, também presente no Tabernáculo e no Templo.

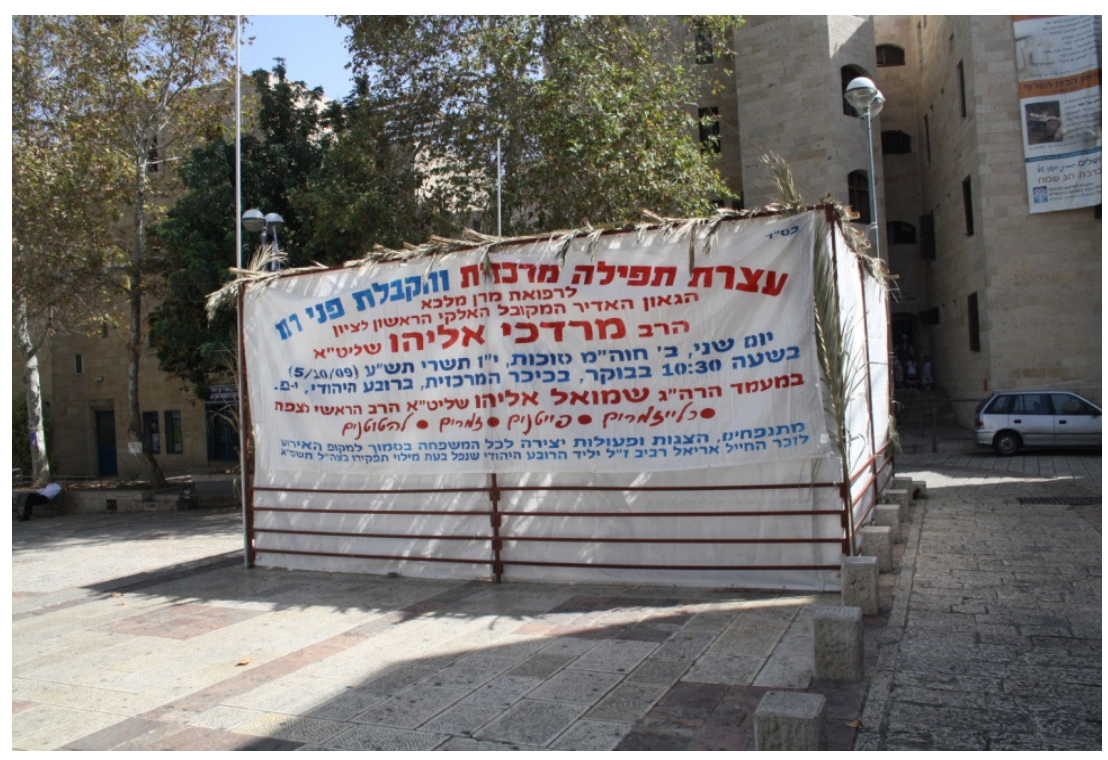

Figura 19: Sukah em praça do bairro judeu em Jerusalém, Israel. Foto: Sergio Rugik Gomes.

\subsection{As Mulheres}

Os sábios e intérpretes da lei entenderam que a separação entre homens e mulheres no Templo também deveria ocorrer na sinagoga. Flavio Josefo (2004, p.1340), um historiador judeu e cidadão romano contemporâneo ao Segundo Templo, afirmou que:

O oratório destinado às mulheres estava separado do restante por um muro e havia duas portas, uma do lado do sul, e outra do lado do norte, pelas quais somente se entrava. A entrada do oratório era permitida não só às mulheres de nossa nação, que habitavam na Judéia, mas também às que vinham por devoção de outras províncias, para prestar sua homenagem a Deus.

Se um homem piedoso visse uma mulher no momento das orações, sua visão poderia estimular a cobiça, o que poluiria sua oração e a ele mesmo. Algum tipo de barreira entre homens e mulheres preveniria esse problema. Dessa forma, diferentes formas de separação foram adotadas nas sinagogas uma nave anexa separada por uma cortina, balcões com muxarabis ou apenas uma simples diferença na cota do piso. As barreiras visavam a uma maior santificação. A sessão 
das mulheres era considerada menos sagrada que a dos homens e não representava parte do "santuário". Geralmente, existiam menos assentos para as mulheres e, mesmo que alguns serviços fossem voltados exclusivamente para as mulheres, nestes a arca e a bimah ficavam trancadas, pois apenas aos homens era dado o direito de ler a Torah e de aprender o hebraico.

Assim, apenas poucas mulheres atendiam aos serviços. A Lei judaica exime a mulher da participação na sinagoga por causa de suas obrigações domésticas. As mulheres não eram contadas no quorum e não podiam ler a Torah sobre a bimah ou tornarem-se rabinos e cantores.

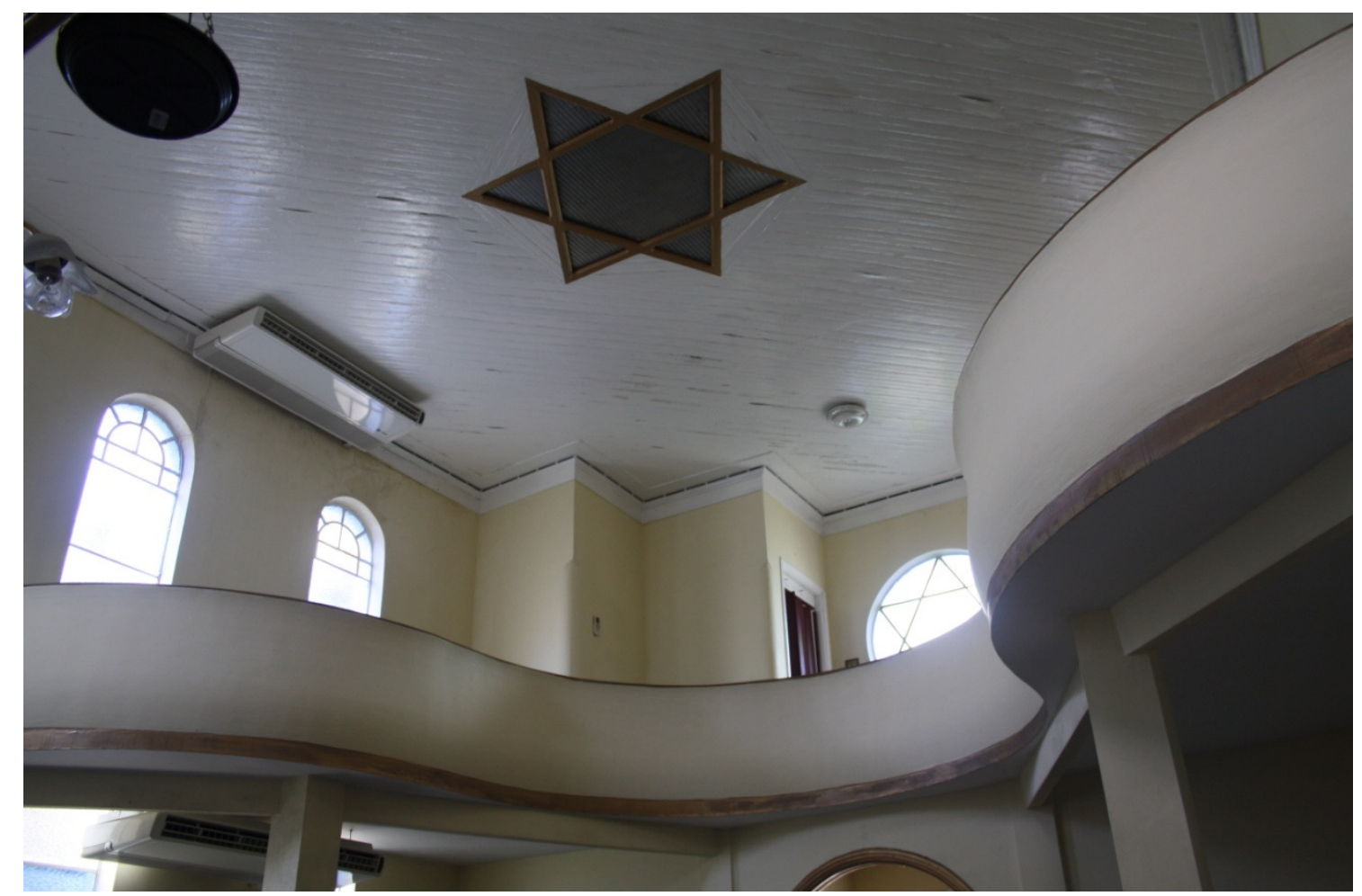

Figura 20: Balcão para as mulheres na sinagoga Beit Zion em Santos (1935). Foto: Sergio Rugik Gomes.

No Templo, pelo menos em algumas ocasiões, as mulheres eram separadas dos homens. Os intérpretes talmúdicos entenderam que isto também deveria ocorrer na sinagoga. Se um homem piedoso vê uma mulher no momento em que recita a oração do Shemah, sua visão pode estimular a cobiça, o que poluiria sua oração e a ele mesmo. Por isso algum tipo de barreira entre homens e mulheres preveniria este problema. Por um longo tempo sequer existiu um 
espaço para as mulheres nas sinagogas. Apenas algumas poucas mulheres atendiam aos serviços.

\subsection{O Rabino e o Chazan}

Rabino significa literalmente "mestre" ou "professor". Ele tem o papel de pregador e mestre e sua função está mais ligada ao ensino. Ele também trata das questões pertinentes ao dia a dia da congregação, de atividades da comunidade, dos eventos ligados aos feriados judaicos e das celebrações dos acontecimentos no ciclo de vida do judeu, como a circuncisão ${ }^{26}$, o bar mitzvah $^{27}$ ou o casamento. Diferentemente de um padre, ele não cumpre o papel de representante de Deus ou intermediário, mas apenas de alguém que tem maior profundidade no conhecimento da lei judaica.

Entretanto os serviços religiosos não demandam a presença obrigatória de um rabino, podendo ser conduzidos por um membro da comunidade. O único requisito obrigatório é a presença do minian, o quorum mínimo para a realização dos serviços, composto por dez homens judeus adultos. É importante também na liturgia a presença de um chazan, "cantor" que deve ser um estudioso da língua hebraica e da Torah, pois é ele quem guia a congregação nas orações e recita as bênçãos durante os serviços.

\subsection{Mikveh}

Dependendo das necessidades da comunidade e dos recursos de que dispõe, sua sinagoga pode ter agregadas, ao salão de orações, outras instalações ou fazer parte de um complexo com escritórios, casa de estudo, escola para crianças, apartamentos para os oficiantes, salão social, etc. Pode haver ainda estruturas voltadas à liturgia como uma padaria, banho ritual, matadouro kasher $^{28}$ ou necrotério temporário, entre outros (KRINSKY, 1996). É mais usual que a sinagoga

\footnotetext{
${ }^{26}$ A circuncisão refere-se à cerimônia de remoção da carne do prepúcio e tem lugar fundamental na identidade do homem judeu.

27 Bar Mitzvah é a cerimônia de passagem do menino judeu para a idade adulta.

${ }^{28}$ Kasher é o termo usado para referir-se aos alimentos dentro das leis dietéticas da Torah que indicam o que é e o que não é apropriado para o consumo
} 
disponha de um pátio que comporte serviços ao ar livre como a construção de uma cabana para o feriado de sukot $t^{29}$. Uma mikvêh, a piscina ritualística, também é um elemento importante no conjunto, o que demandará um sistema específico de coleta de água da chuva ou de uma nascente. Nela são realizadas banhos de purificação necessários em diferentes eventos, como por ocasião de uma conversão, antes do Shabat, depois do ciclo menstrual da mulher, entre outros. Sua presença na sinagoga também remete ao Tabernáculo e ao Templo de Jerusalém.

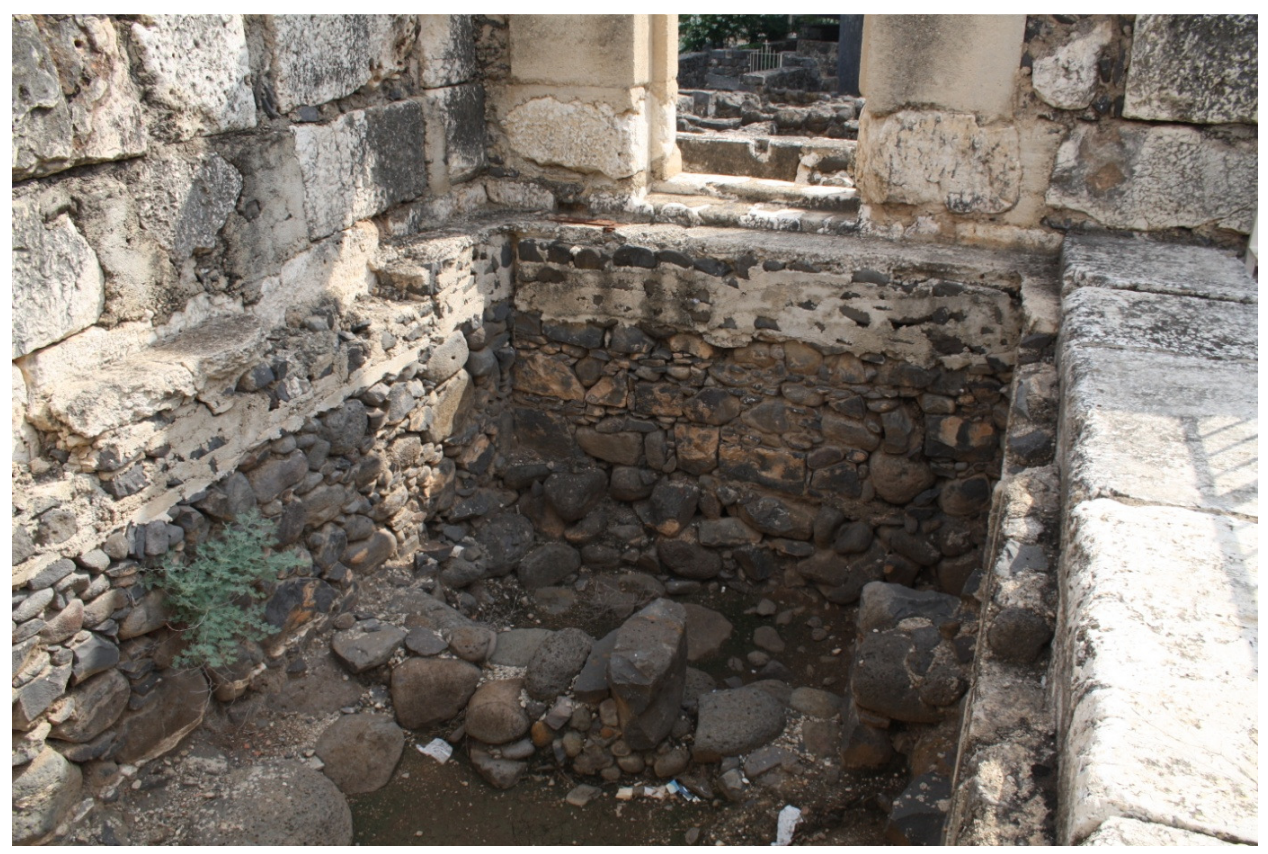

Figura 21: Mikveh na antiga sinagoga de Cafarnaum, Israel. Foto: Sergio Rugik Gomes.

\subsection{Símbolos e Decoração}

É comum o uso de símbolos e de decoração na sinagoga. Em determinadas épocas, apesar do caráter iconoclasta da religião judaica, a decoração era feita com imagens de seres humanos e animais, mas certamente não foram vistos como uma ameaça à pureza do edifício. As sinagogas normalmente não possuem nenhuma característica arquitetônica que as distingue dos demais edifícios, por isso símbolos como a menorah, a estrela de Davi ou os dez mandamentos são utilizados na sua identificação.

${ }^{29}$ Sukot é uma importante festa judaica onde é necessário alimentar-se e realizar outras atividades dentro de uma espécie de cabana. 
$\mathrm{Na}$ história também podem ser vistas diferentes referências ao Templo, ou ao que se imaginava sobre sua forma, como meio de identificação. Internamente, além destes símbolos, são comuns o uso de referências às colunas chamadas Boaz e Joakim, na entrada do Templo, a "luz eterna" que pende em frente à arca, os símbolos do zodíaco, dentre outros.

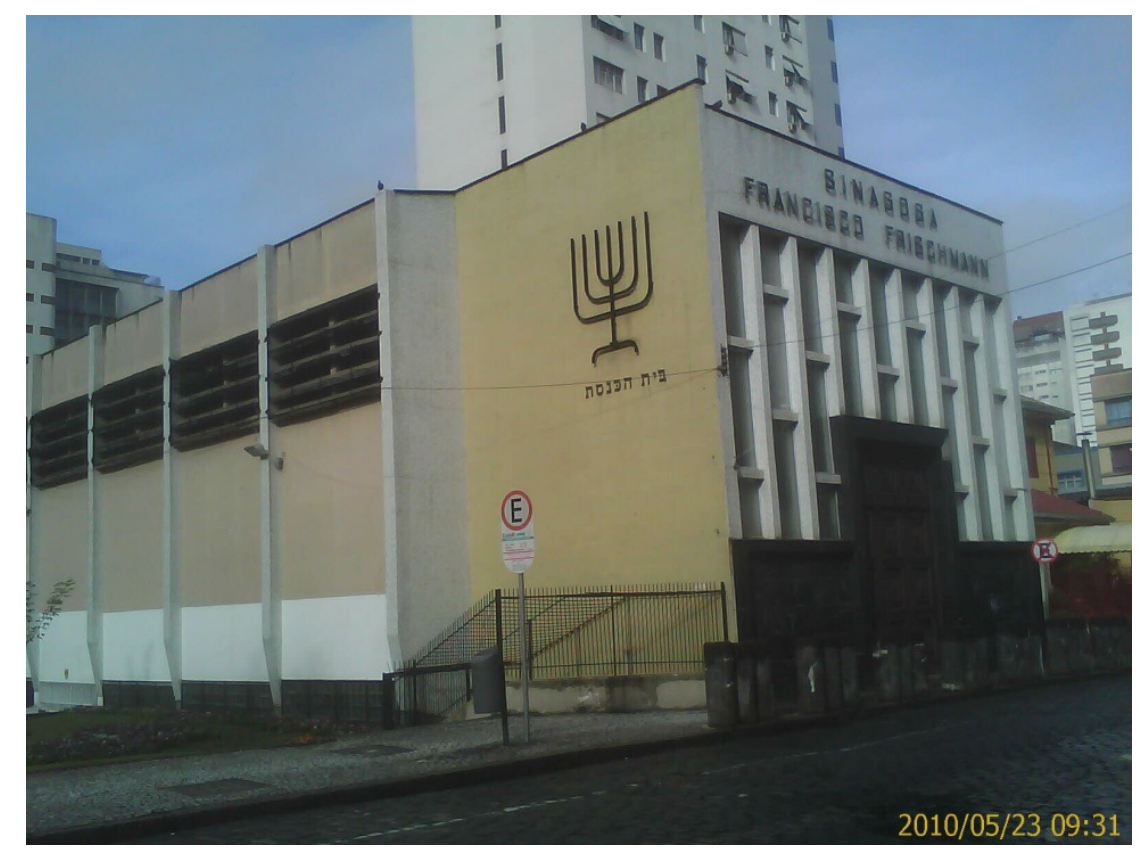

Figura 22: A menorah na fachada da sinagoga Francisco Frischmann em Curitiba. Foto: Sergio Rugik Gomes. 


\section{CAPÍTULO 2 - EVOLUÇÃO NO TEMPO}

É proposta nesta etapa um panorama global das sinagogas escolhidas para exemplificar cada uma das fases históricas a serem analisadas. Estes edifícios foram considerados relevantes devido a sua capacidade em demonstrar as transformações sofridas arquitetônicas decorrentes das condições pelas quais as comunidades judaicas passaram. Esse panorama objetiva uma visão geral dessas transformações de forma compacta.

\section{O Templo de Jerusalém}
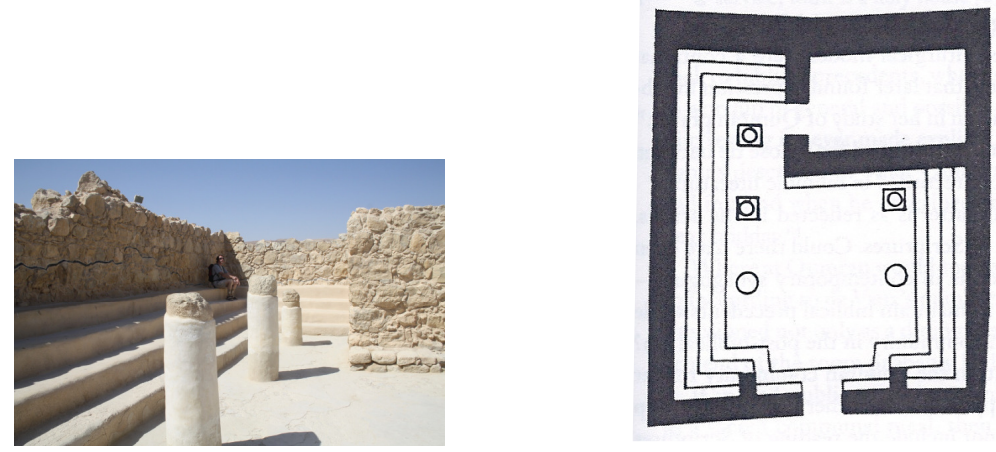

66 a 74 d.C. - Sinagoga de Massada, Israel.
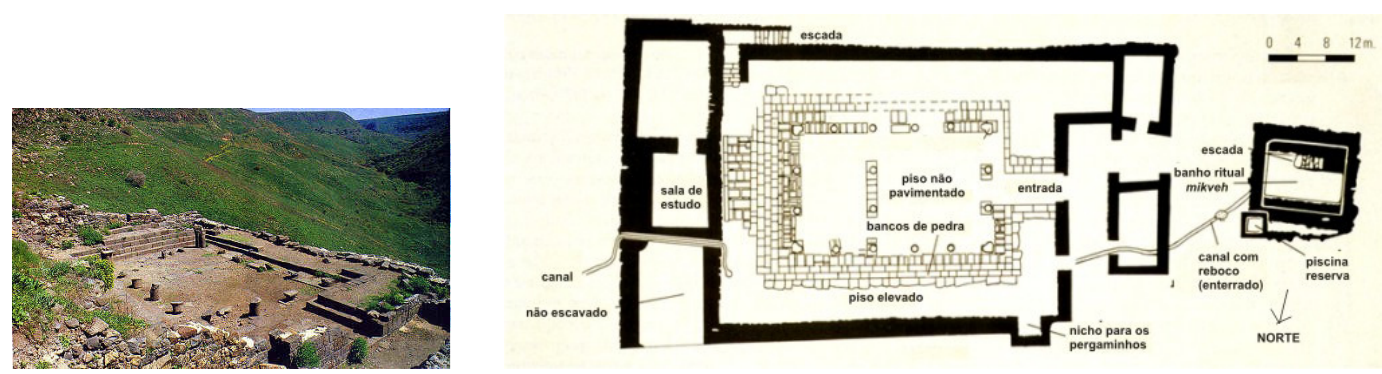

Séc. I d.C. - Sinagoga de Gamla, Israel.
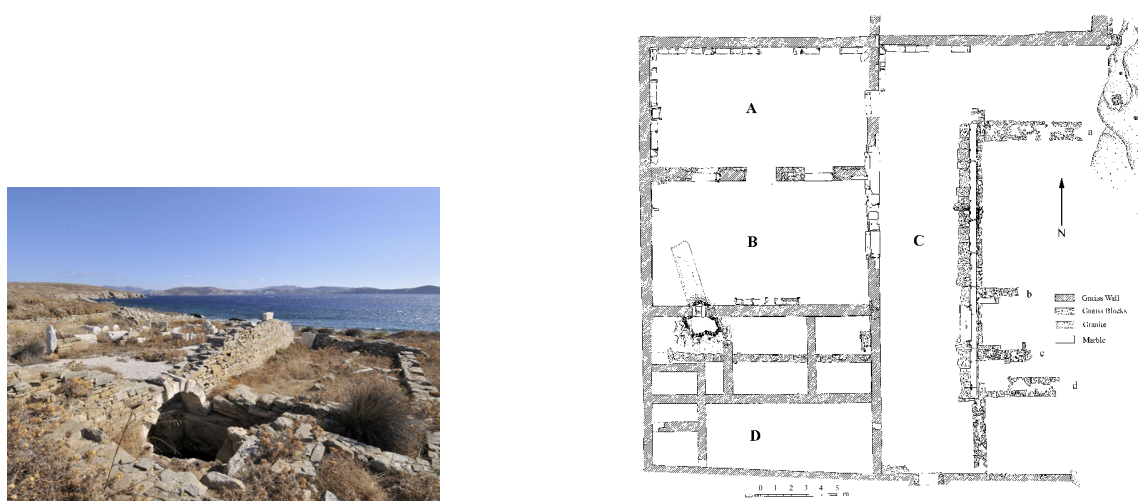
Séc. I a.C. - Sinagoga de Delos, Grécia.

\section{Diáspora}
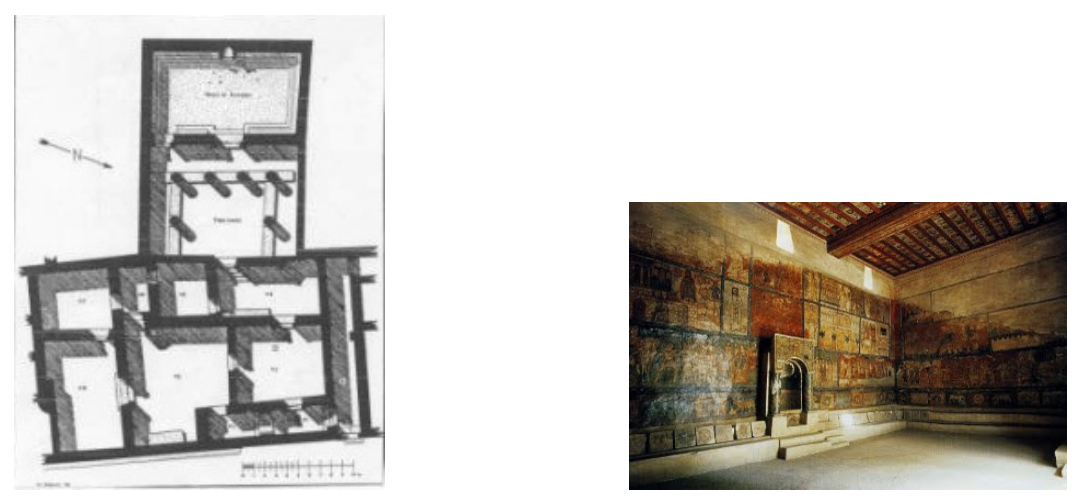

245 d.C. - Dura-europos, Síria
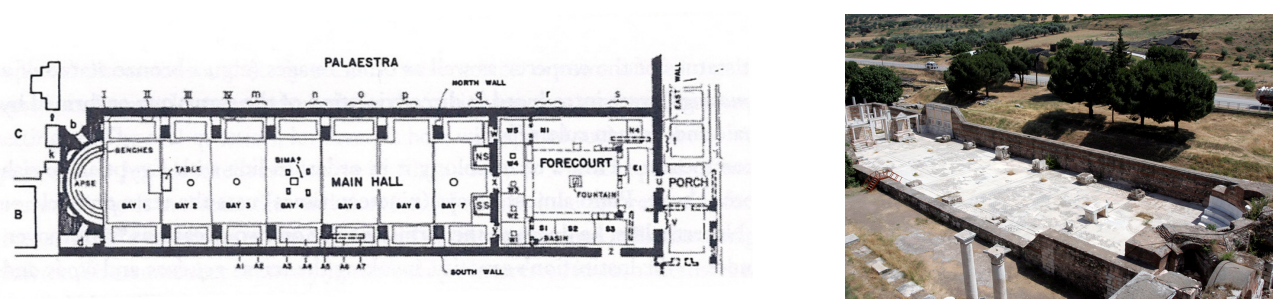

380 d.C. - Sardes, Turquia
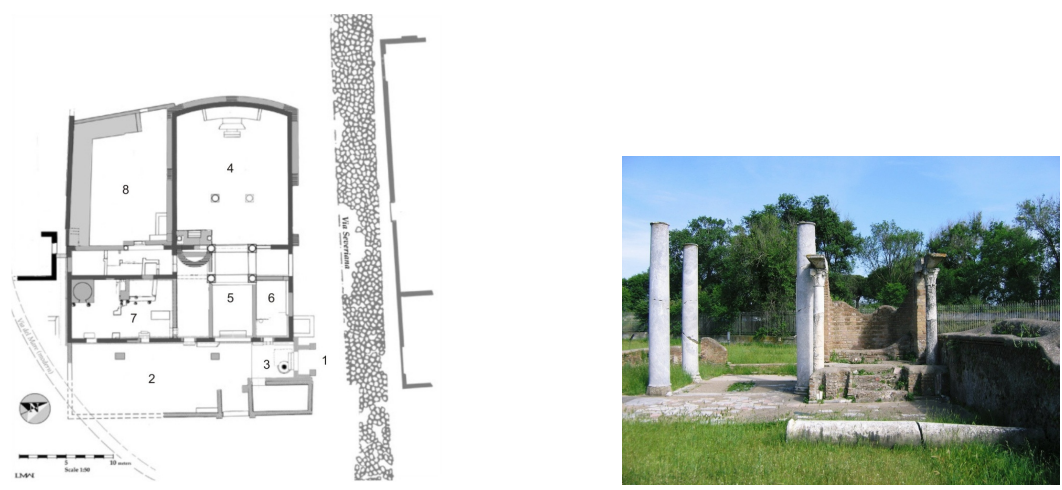

Século IV d.C. - Ostia, Itália

\section{Ascensão do Cristianismo}



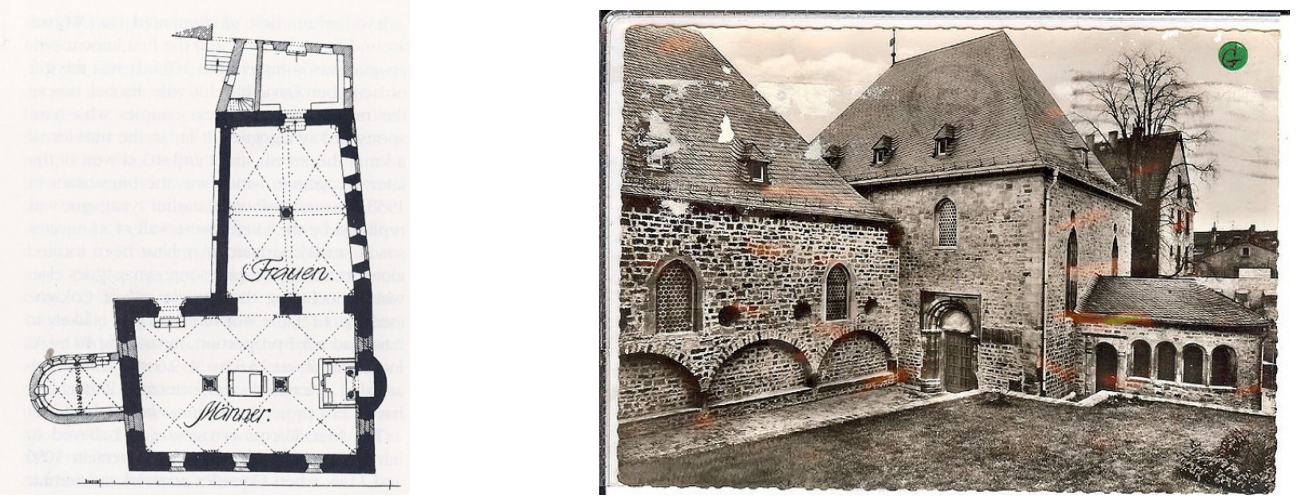

Sinagoga de Worms, Alemanha - 1174
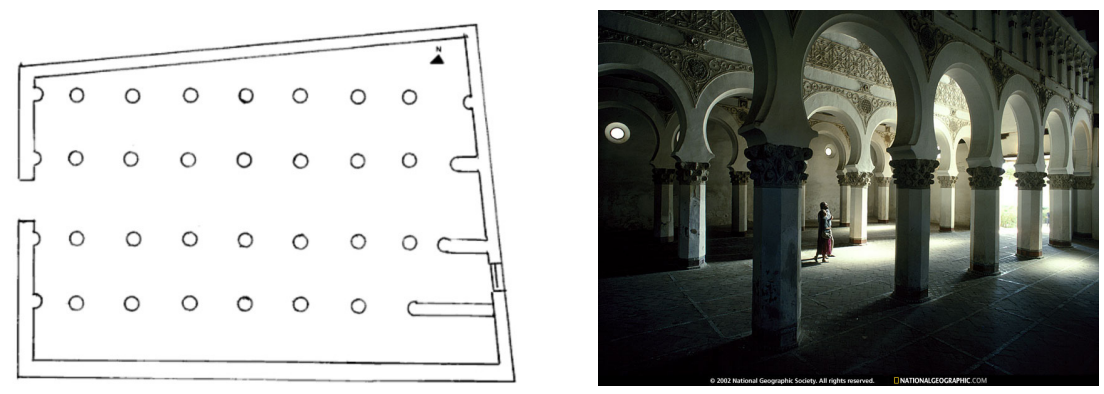

Sinagoga "Santa María la Blanca" em Toledo, Espanha - SÉC.XIII
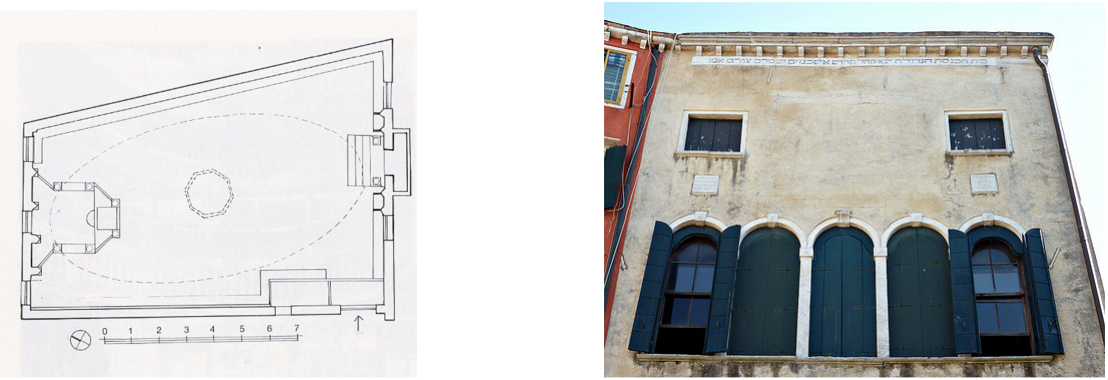

Sinagoga Scuola Grande Tedesca em Veneza, Itália - 1733

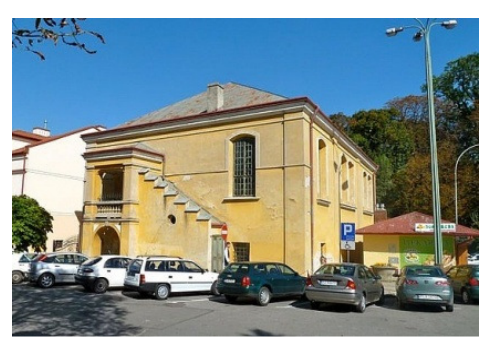

Sinagoga de Lancút

Fonte: <http://images.travelpod.com/users/slice_n_dice/1.1285105920.lancut-synagogue.jpg> Acesso em: 08 fev. 2011. 


\section{Emancipação}
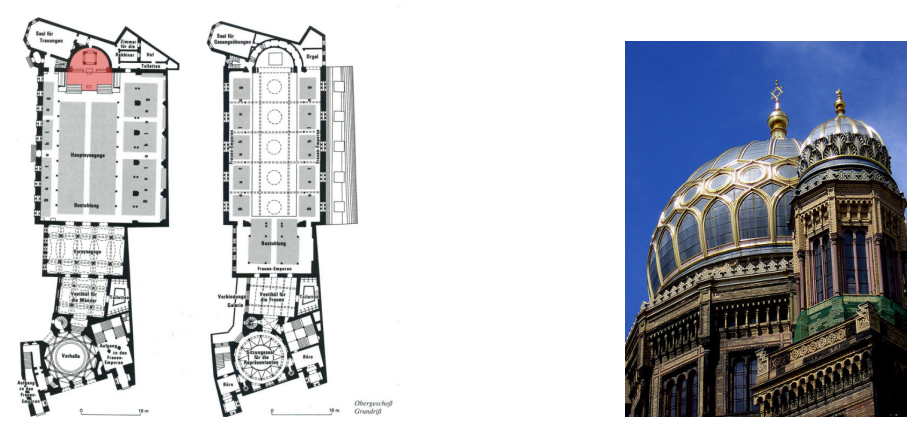

Berlin, Alemanha - 1859.

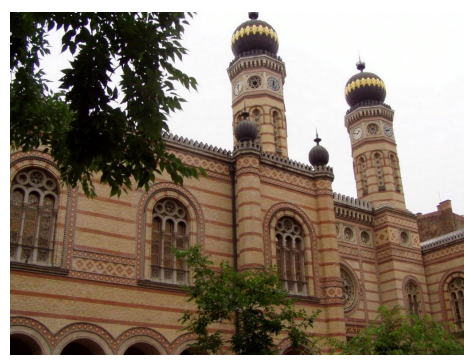

Budapest, Hungria - 1866.
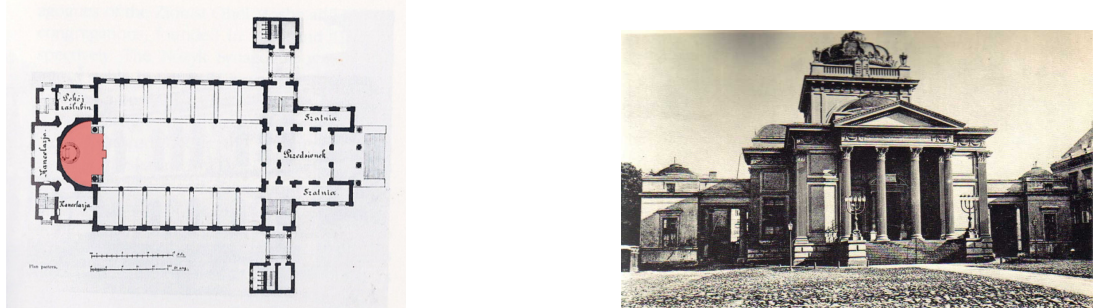

Varsóvia, Polônia - 1874.

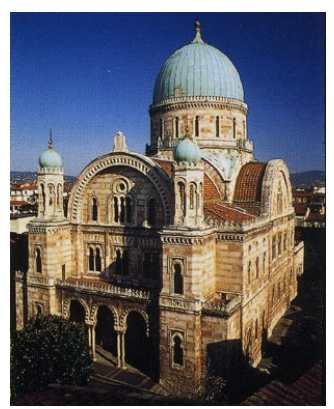

Florença, Itália - 1882. 


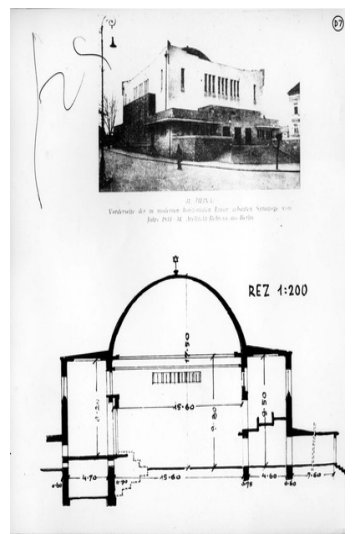

Zilina, Eslováquia - 1928.

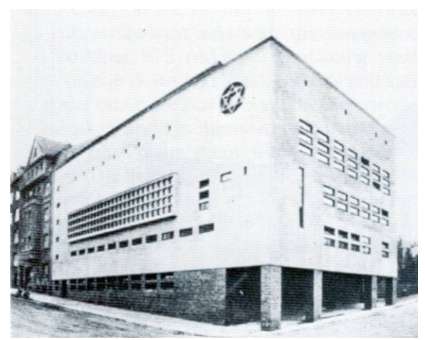

Plauen, Alemanha - 1930.

\section{Pós-guerra}
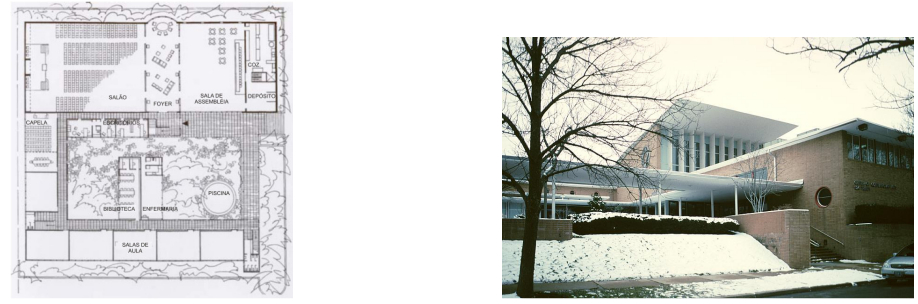

Sinagoga B'nai Amoona, EUA - 1950

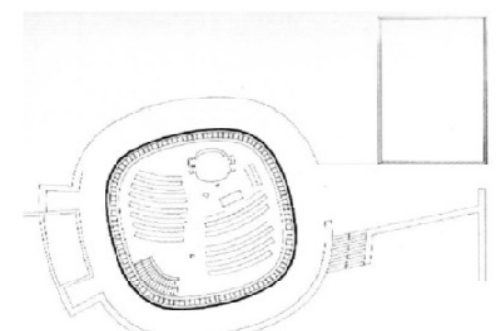

Sinagoga da Universidade Hebraica de Jerusalém - 1957 


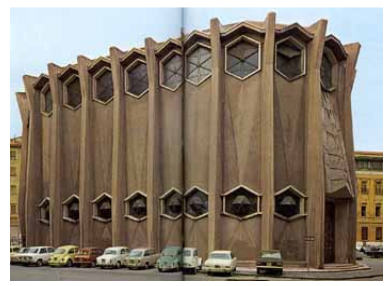

Sinagoga de Livorno, Itália - 1962
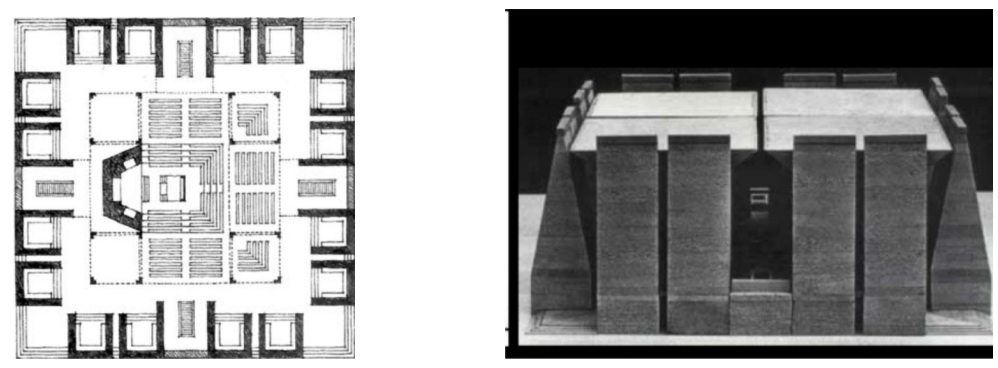

Projeto para a sinagoga de Hurva, Israel - 1974.
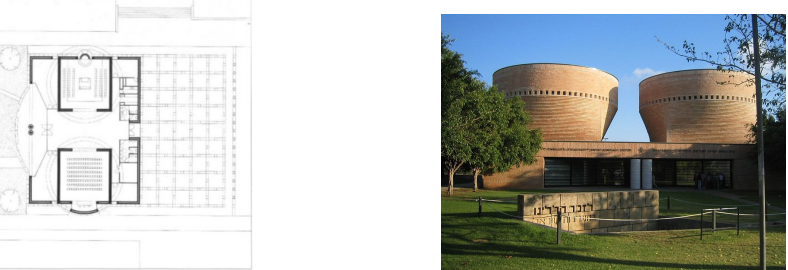

Sinagoga Cymbalista, Israel - 199 


\section{TEMPLO DE JERUSALÉM}

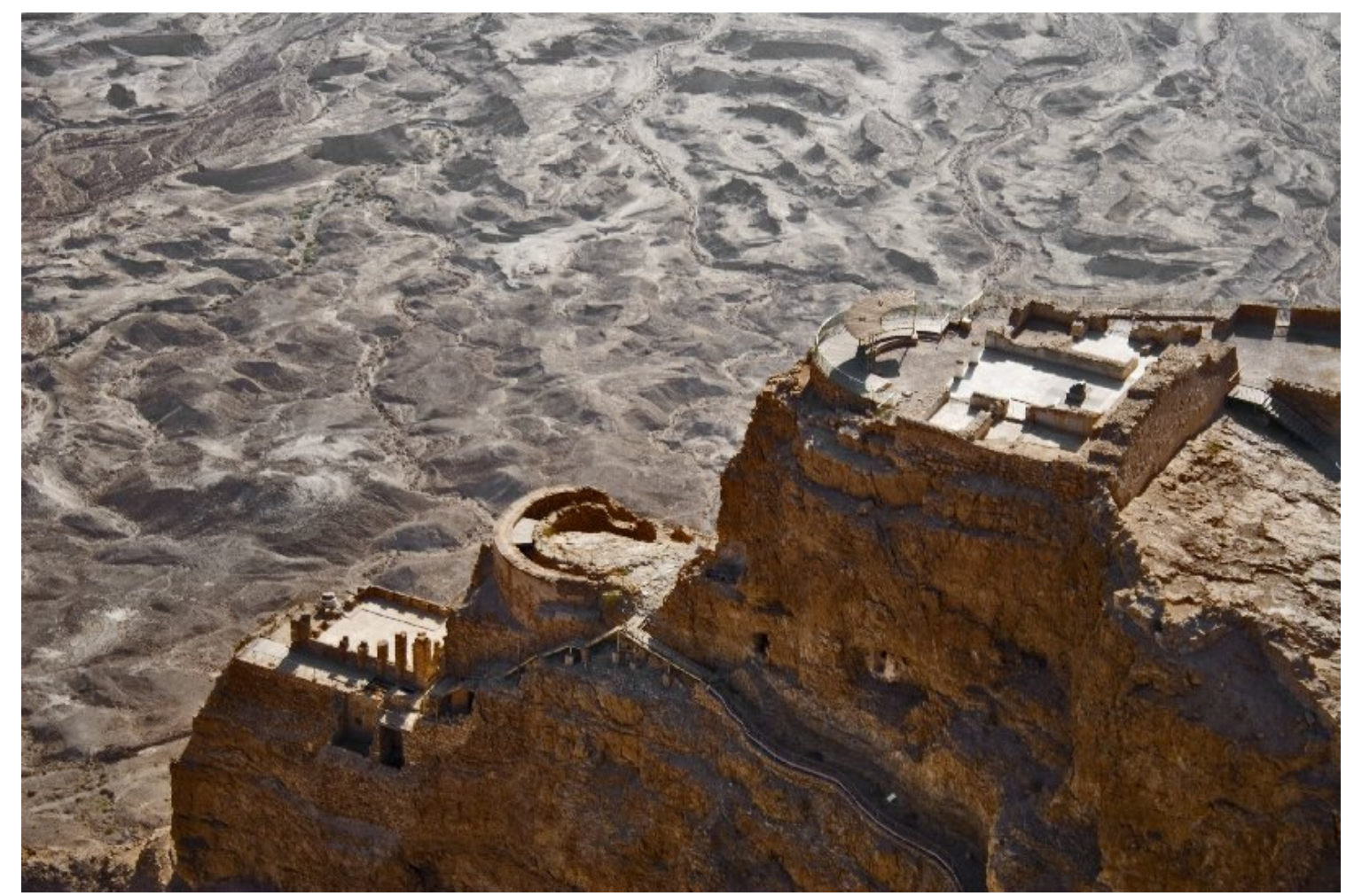

Figura 23: foto aérea da fortaleza de Massada, Israel. Fonte: <http:// http://imperioroma.blogspot.com/2010/06/massada-ultima-fortaleza.html> Acesso em: 13 dez. 2010.

\subsection{Contexto Histórico}

O período aqui denominado "O Templo de Jerusalém" abrange as sinagogas contemporâneas ao Segundo Templo, edifício central do judaísmo naquele momento, edificado em 538 a.C. e destruído em 70 d.C. durante o assalto à Jerusalém pelos exércitos romanos. Dentre as sinagogas ao redor do mundo, estas são as que menos informações trazem consigo. Poucas são as que podem ser identificadas com precisão como sinagogas. Seus registros são sítios arqueológicos presentes na palestina e no mundo romano. Menções sobre elas podem ser encontradas em fontes epigráficas ${ }^{30}$ e textuais. Pouco se pode determinar sobre sua forma exterior, entretanto suas plantas ainda podem ser reconstituídas, tornando-se o elemento mais legível destas edificações.

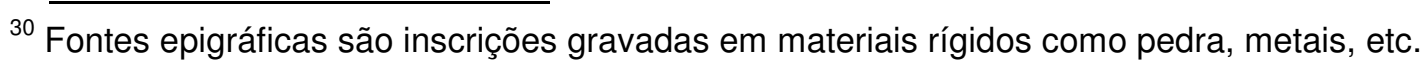


Tendo em vista que a maior parte da história do povo judeu se dá no exílio $^{31}$, é coerente afirmar que esse período contemporâneo ao Templo é peculiar dentre os demais. A existência de Israel como nação vai influenciar a arquitetura da sinagoga de forma que ela não precisará, até esse momento, atender à necessidades específicas de comunidades exiladas. Além disso, havia também a presença física do Templo de Jerusalém, instituição intimamente vinculada ao estilo de vida do povo judeu. Certas relações hierárquicas, funções religiosas, exigências regulamentares e festividades anuais só podiam ser cumpridas no Templo ou de alguma forma relacionadas a ele. Sua presença e posterior destruição vão influenciar profundamente a arquitetura das sinagogas. Apesar de existir como nação, antes de 70 d.C. Israel pertencia ao Império Romano, o que também ocasionou uma forte influência da cultura helenística nos edifícios sinagogais da época.

Três sinagogas foram escolhidas para apresentar esse período. Duas delas estavam estabelecidas em Israel. A terceira se encontrava em Delos, uma ilha da Grécia. Essa diferença geográfica afetou de forma diferente essas comunidades e as consequências de sua influência podem ser observadas em sua arquitetura: Sinagoga de Massada, Israel - 66 a 74 a.C, Sinagoga de Gamla, Israel - Séc. I a.C, Sinagoga de Delos, Grécia - Séc. I a.C.

\subsection{Programa de Necessidades}

Um aspecto que pode ser observado nesse período, principalmente nas sinagogas da palestina, é a simplicidade do programa de necessidades. Voolen (2004) explica que nessa fase o edifício sinagogal foi caracterizado por uma arquitetura suficiente apenas para atender as necessidades básicas para as quais a sinagoga se prestava: oração, estudo e reuniões comunitárias, o que podia ser alcançado simplesmente pelo salão de reuniões, sem a necessidade de um complexo de instalações. Isto pode ser observado na sinagoga de Massada, uma fortaleza-retiro, edificada próxima ao Mar Morto (fig.23), posteriormente ocupada por revolucionários Zelotes ${ }^{32}$ entre 66 d.C. e 74 d.C., que resistiram durante anos a um

${ }^{31}$ Exílio aqui se refere às localidades onde os judeus se estabeleceram depois de terem deixado a Palestina em 70 d.C.

32 Zelotes: uma facção extremista da época. 
cerco romano. Sua sinagoga (fig.24) é composta apenas do salão de reuniões cercado por bancos em quatro fileiras, exceto pela parede norte com um pequeno cômodo fechado aos fundos (LEVINE, 2005).

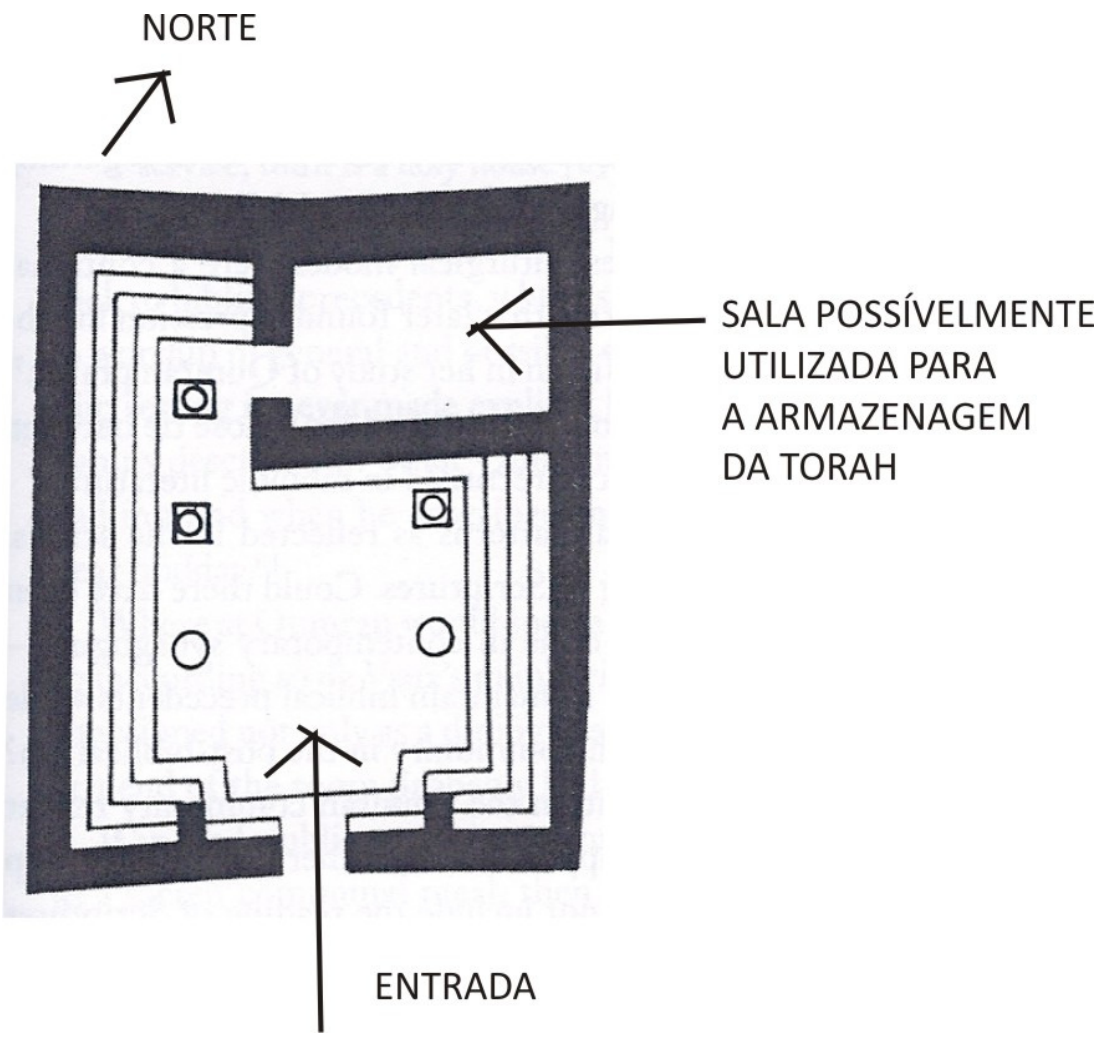

Figura 24: Planta da sinagoga de Massada (editado pelo autor). Fonte: Levine, 2005, p.63.

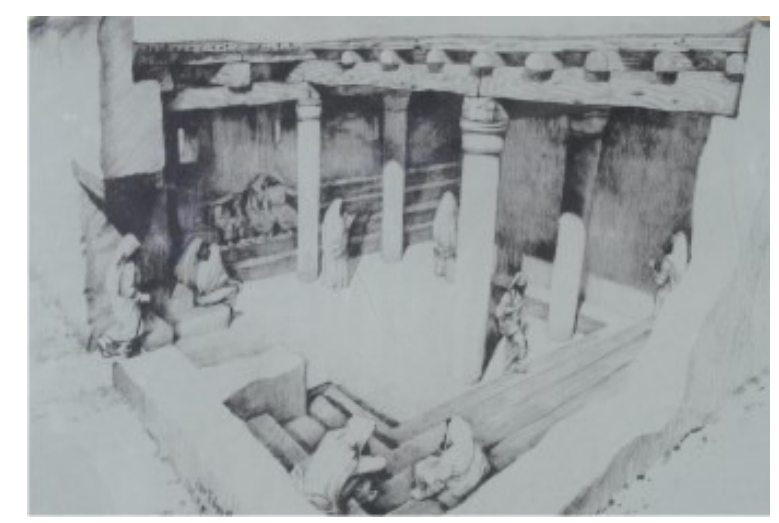

Figura 25: Reconstituição da sinagoga de Massada. Fonte: Gravura de Lev Filipp - Israel Nature and Parks Authority.

Além de Massada, as outras sinagogas desse período edificadas na palestina, também são compostas apenas pelo salão de reuniões ou, quando apresentam outras instalações, tem neste sua ênfase maior, como na sinagoga de Gamla (fig.32) . Nessa fase apenas o edifício em Delos (fig.28) apresenta um 
número razoável de outros cômodos que pelas condições dos achados arqueológicos não puderam ser identificados. Entretanto, pela sinagoga de Delos ter sido edificada fora da Palestina, ela pode ter refletido em seu edifício as necessidades de uma comunidade exilada, onde determinadas funções que não poderiam ser encontradas na localidade precisaram ser agregadas ao edifício da sinagoga.

\subsection{Influência da Localidade}

Outro aspecto das sinagogas contemporâneas ao Templo é que estas se mostram neutras, sem componentes importantes de cunho religioso como inscrições ou representações artísticas. Esta talvez seja a característica mais presente entre sinagogas dessa fase. É possível que a presença do Templo, como instituição religiosa central do judaísmo, dispensasse a sinagoga desse caráter.

As soluções dadas à acomodação da $\operatorname{Torah}^{33}$ poderiam constituir uma exceção. Na sinagoga de Massada, a pequena sala construída nos fundos do salão de reuniões foi edificada possivelmente para este fim (fig.26). Esta conclusão tem base nos fragmentos de pergaminhos dos textos utilizados na liturgia, encontrados nas escavações arqueológicas. Levine (2005) afirma que a forma como se guardavam os pergaminhos, na sinagoga de Massada, poderia apontar para uma solução que viria a se tornar uma constante na sinagoga, uma estrutura preparada especificamente para receber o objeto mais sagrado da sinagoga, a Torah, atendendo determinações específicas da lei judaica. Entretanto ele explica que a sinagoga de Massada foi a única dests fase que apresenta um cômodo para este fim.

${ }^{33}$ Torah é o nome dado ao pergaminho contendo os cinco primeiros livros do Tanah, o equivalente ao Antigo Testamento da Bíblia cristã. Sua leitura tem lugar central no serviço religioso na sinagoga. 


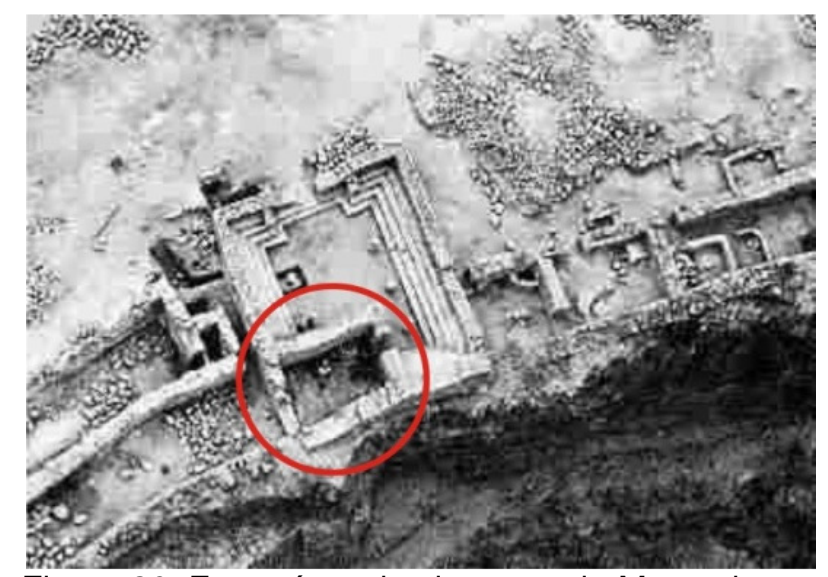

Figura 26: Foto aérea da sinagoga de Massada com destaque para o cômodo da Torah (destaque do autor). Fonte: http://www.pohick.org/sts/masada.html acesso em 10/12/2010.

A miqveh, um tipo de piscina utilizada para rituais de purificação de suma importância na sociedade judaica e requisito inclusive para se adentrar aos recintos do Templo, também poderia ser um elemento de caráter religioso nas sinagogas desse período. A sinagoga de Gamla contava com uma cisterna a oeste (fig.27). Ela poderia ter sido utilizada como uma miqveh, entretanto, como na maioria dos casos desse período, ela estava localizada nas proximidades e não no corpo do edifício. Na sinagoga de Delos, ao sul da edificação, sob uma série de pequenos cômodos (fig.28), está um grande reservatório de água, que pode ter sido usado como uma miqveh (LEVINE, 2005). Entretanto aqui também não é possível afirmar se essa cisterna realmente servia como uma mikveh e, mais recentemente questionou-se, inclusive, se Delos poderia ser ou não identificada como uma sinagoga ${ }^{34}$.

${ }^{34}$ Existem estudos que questionam a identificação deste edifício em Delos. Entretanto adota-se aqui a posição de Levine (2005) que aceita sua identificação como sinagoga. 


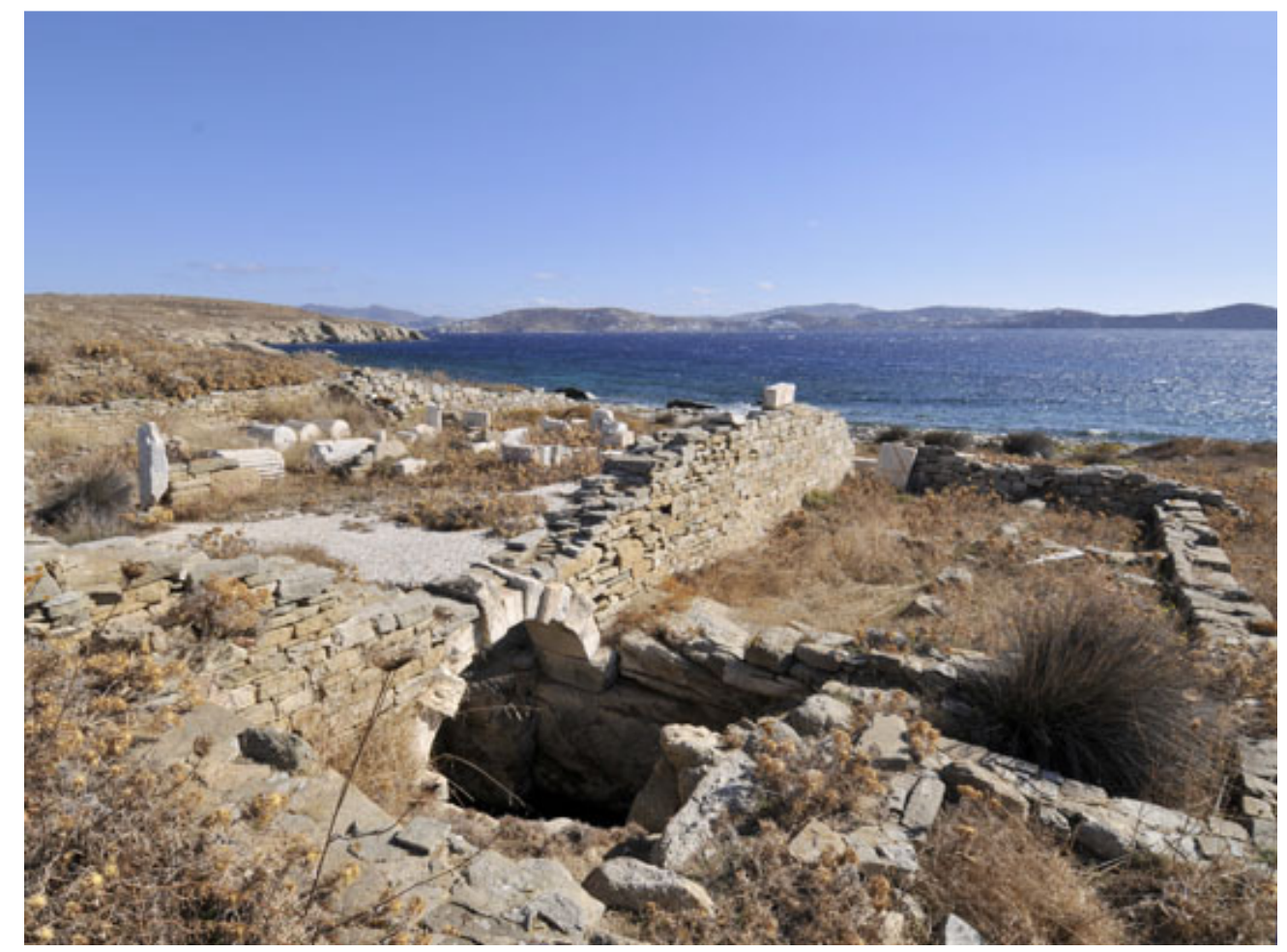

Figura 27: Foto das ruínas da sinagoga de Delos com possível mikveh.

Fonte: <http://synagogues360.net/synagogues.php?ident=greece_004> Acesso em: 10 dez. 2010.

Entretanto, com a posição de Levine (2005) de assumir o edifício em Delos como uma sinagoga (fig.28), esta se constitui um exemplo da influência exercida pela arquitetura de uma localidade fora da Palestina. O complexo da sinagoga era composto de três partes: um átrio voltado para o leste, com bancos de mármore (fig.28-C), um grande salão posteriormente dividido em dois por um portal triplo com uma poltrona entalhada (fig.28-A/B), talvez uma Cadeira de Moisés ${ }^{35}$. Como esta comunidade se encontrava distante de sua terra natal, seu edifício vai conter mais similaridades com a arquitetura da região onde se estabeleceu do que com as sinagogas da Palestina, fenômeno que posteriormente vai se estender por toda a diáspora ${ }^{36}$. Isto se deve à carga de influência que esta comunidade recebia de sua localidade e se deve também ao alto grau de helenização ${ }^{37}$, característico da época. Delos seguiu o padrão de outras instituições locais, que incluíam um grande pátio com pórticos (fig.29), além da possível Cadeira de Moisés, cuidadosamente entalhada, similar às utilizadas em templos pagãos (fig. 30) (LEVINE, 2005).

\footnotetext{
${ }^{35}$ Assento especial reservado para o oficiante e para pessoas de renome na comunidade.

${ }^{36}$ Diáspora refere-se à dispersão dos judeus depois de 70 d.C.

${ }^{37}$ Helenismo refere-se à disseminação da cultura grega.
} 


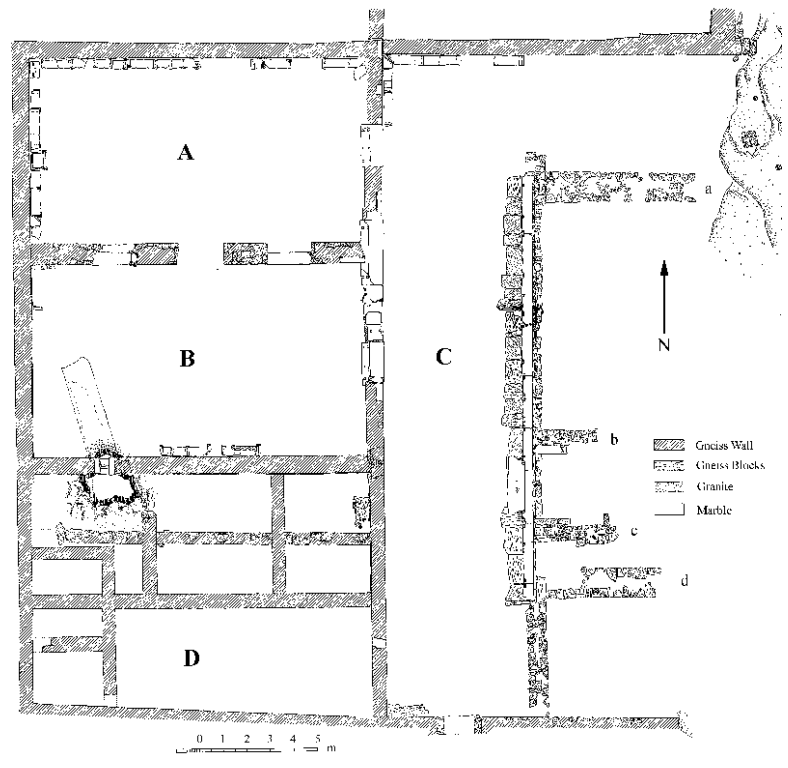

Figura 28: Planta da sinagoga de Delos, Grécia. Fonte: <http://www.pohick.org/sts/delos.html> Acesso em: 10 dez. 2010.

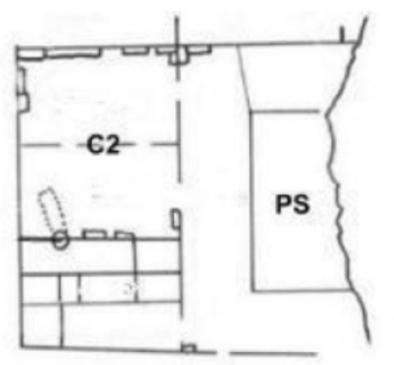

Sinagoga

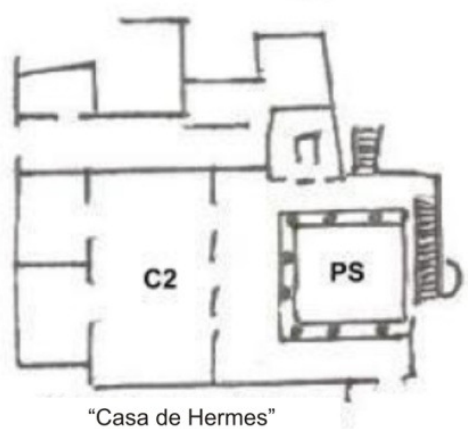

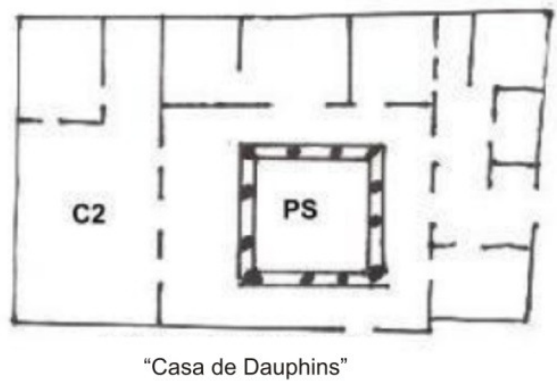

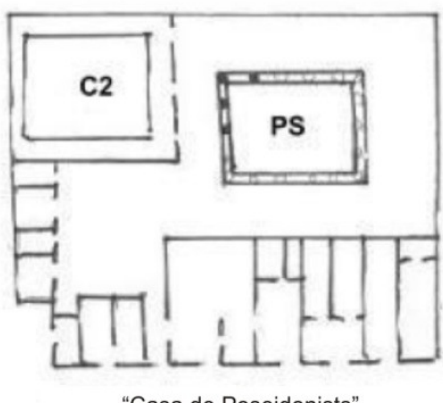

PS = Pátio/Peristilo

C2 = Pátio Coberto

Figura 29: Plantas da sinagoga e de outras edificações em Delos (edição do autor). Fonte: Matassa (2010). 


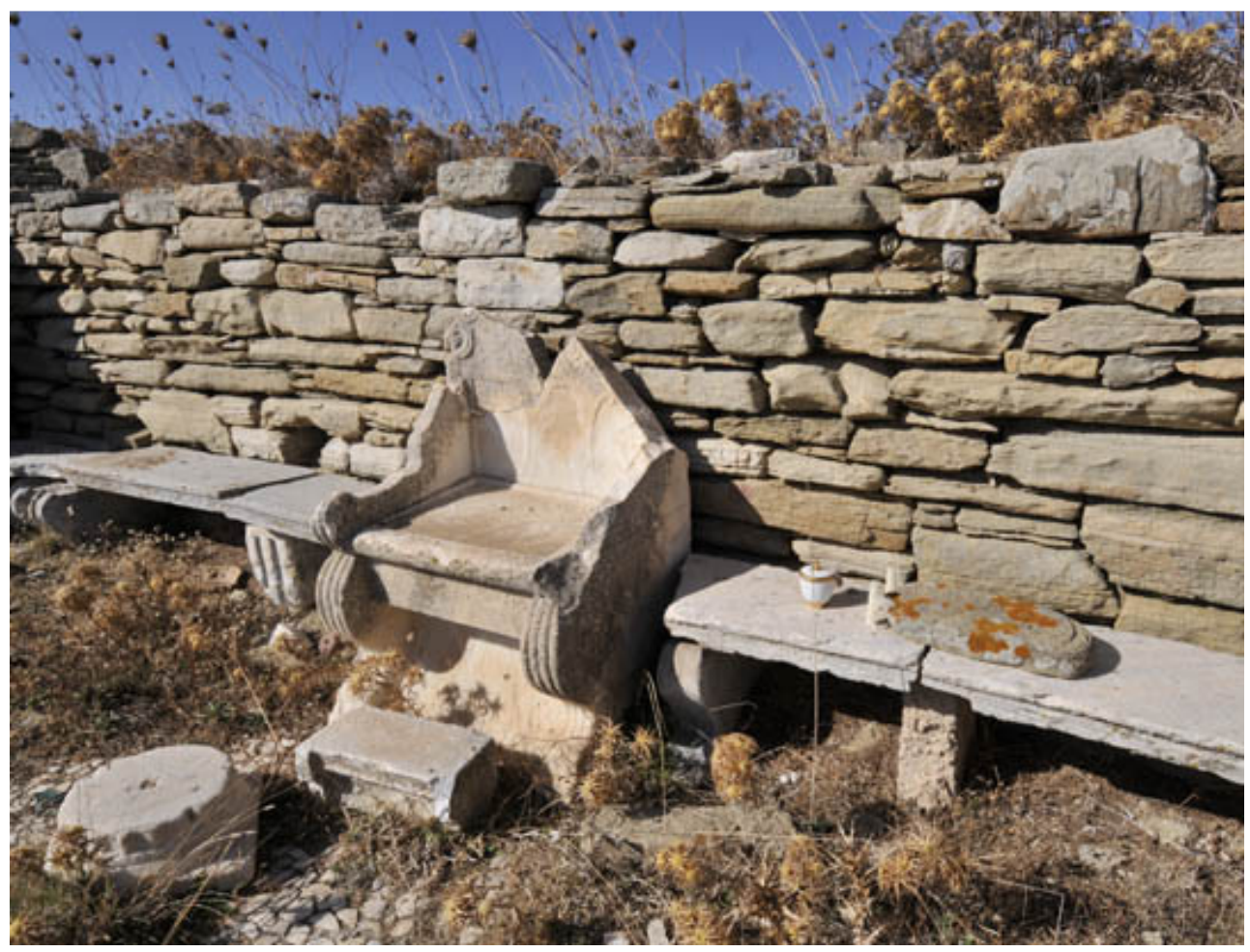

Figura 30: Imagem da cadeira entalhada na sinagoga de Delos.

Fonte: <http://synagogues360.net/synagogues.php?ident=greece_004> Acesso em: 10 dez. 2010.

As sinagogas da Palestina também emprestavam elementos dos estilos arquitetônicos de sua época. Levine (2005) afirma que o povo judeu não possuía uma tradição arquitetônica independente tanto no âmbito público, como no privado. Como resultado disto, teve de emprestar dos estilos arquitetônicos vigentes das sociedades a ele contemporâneas os elementos de sua arquitetura, naquele momento, comumente utilizados na arquitetura dos edifícios públicos romanos. Segundo ele, dada a proporção da imitação dos modelos arquitetônicos do período, seria difícil distinguir uma sinagoga de um edifício não judaico simplesmente pelo seu exterior.

\subsection{Ordenação Interna}

Dentre os elementos utilizados no serviço da sinagoga, a Torah é o objeto revestido de maior santidade, e sua leitura tem lugar central na realização dos serviços. A arca, que armazena a Torah e a bimah, de onde é realizada sua leitura, é essencial na liturgia, e sua organização define a ordenação interna do edifício. Entretanto Levine (2005) afirma que até esse momento esses elementos não 
estavam claramente definidos e talvez nem existissem. Nesse período, a Torah era levada ao salão de reuniões apenas para a realização da leitura, sendo retirada após as reuniões. A sinagoga de Gamla tem em seu interior um nicho que pode ter sido utilizado para guardar a Torah no andamento das reuniões, mas também não há garantias de que tenha sido usado para essa finalidade (fig.31).

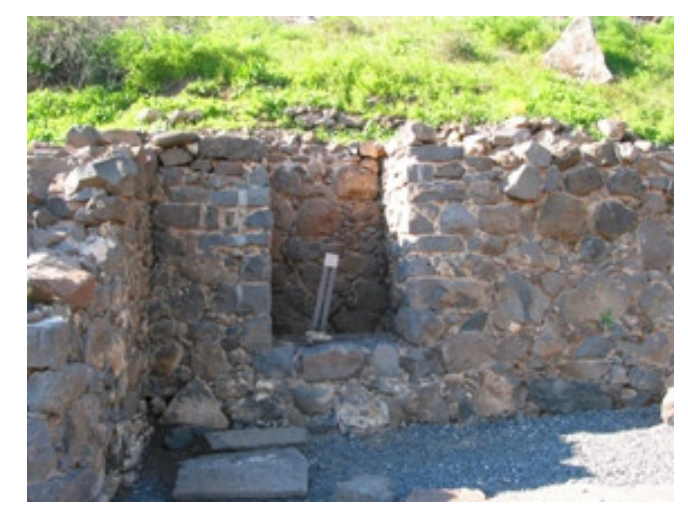

Figura 31: Detalhe de nicho na sinagoga de Gamla.

Fonte: <http://www.nd.edu/ daune/near_east_arch/gamla/gamla.htm> Acesso em: 10 dez. 2010.

O que de fato vai se repetir nas sinagogas desse período e também em Gamla, são as fileiras de bancos que correm ao redor de todo o salão. Elas apresentam salões quadrados ou retangulares com colunas e bancos em um arranjo que facilita o uso para reuniões religiosas, sociais ou políticas. Isto fortalece o entendimento de que esses edifícios estavam envoltos de um aspecto mais comunal do que religioso (LEVINE, 2005). Os bancos de Gamla se encontram abaixo de corredores elevados e na sua frente um corredor pavimentado. Colunas rodeiam um espaço aberto não pavimentado ao centro, com a exceção de uma fileira de pedras atingindo quase toda a sua largura. A leste do salão principal estão alguns cômodos, sendo que um deles poderia ter um tipo de abertura para o salão principal. Este cômodo também continha bancos, o que levou os escavadores a sugerir que possa ter sido uma sala de estudo. 


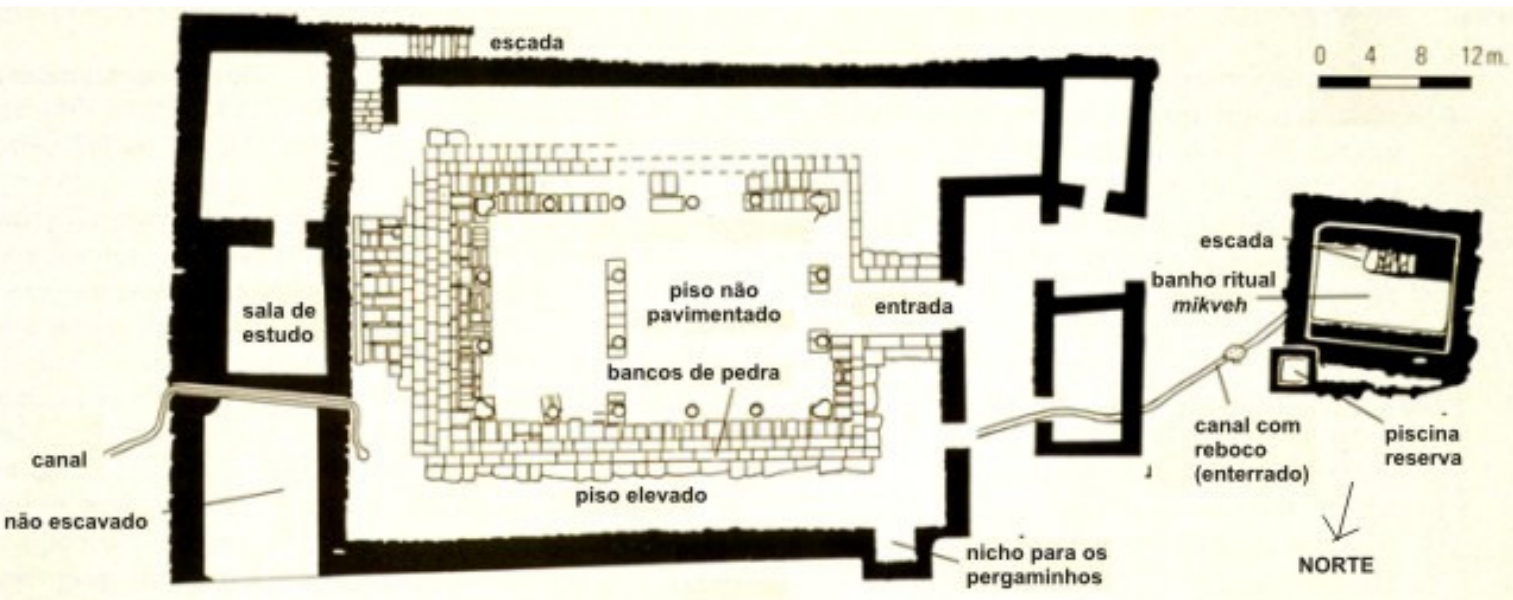

Figura 32: Planta da sinagoga de Gamla (legendas do autor). Fonte:<http://cnes.cla.umn.edu/courses/archaeology/Gamla/GamlaSynagogue.html> Acesso em: 09 dez. 2010.

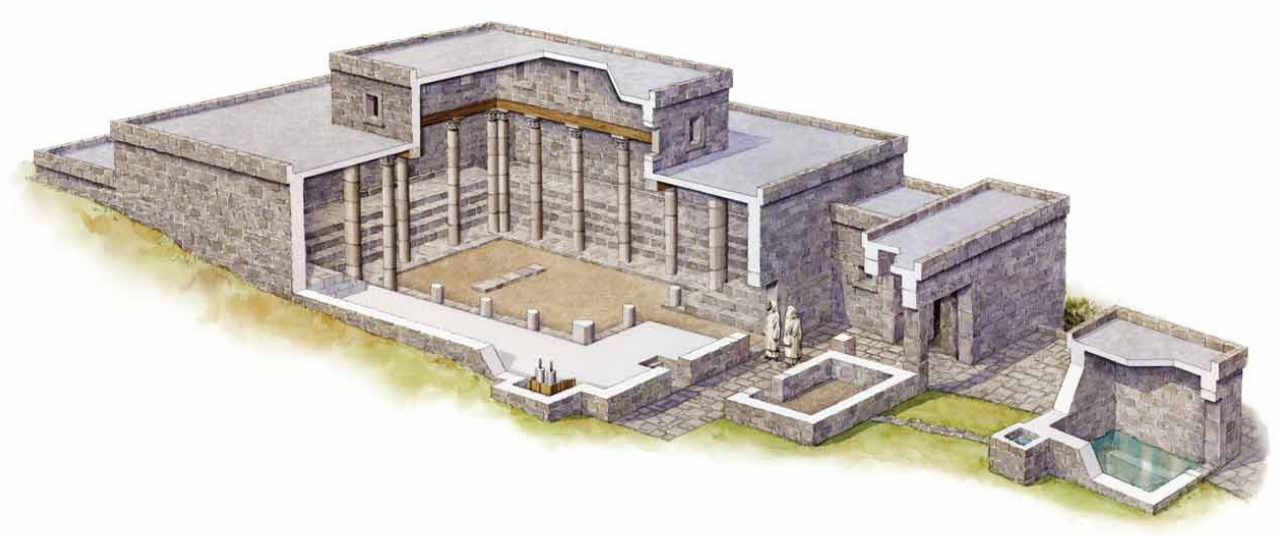

Figura 33: Reconstituição da sinagoga de Gamla.

Fonte: <http://www.esvstudybible.org/blog/2008/08/the-gamla-synagogue-in-the-esv-study-bible/> Acesso em: 09 dez. 2010
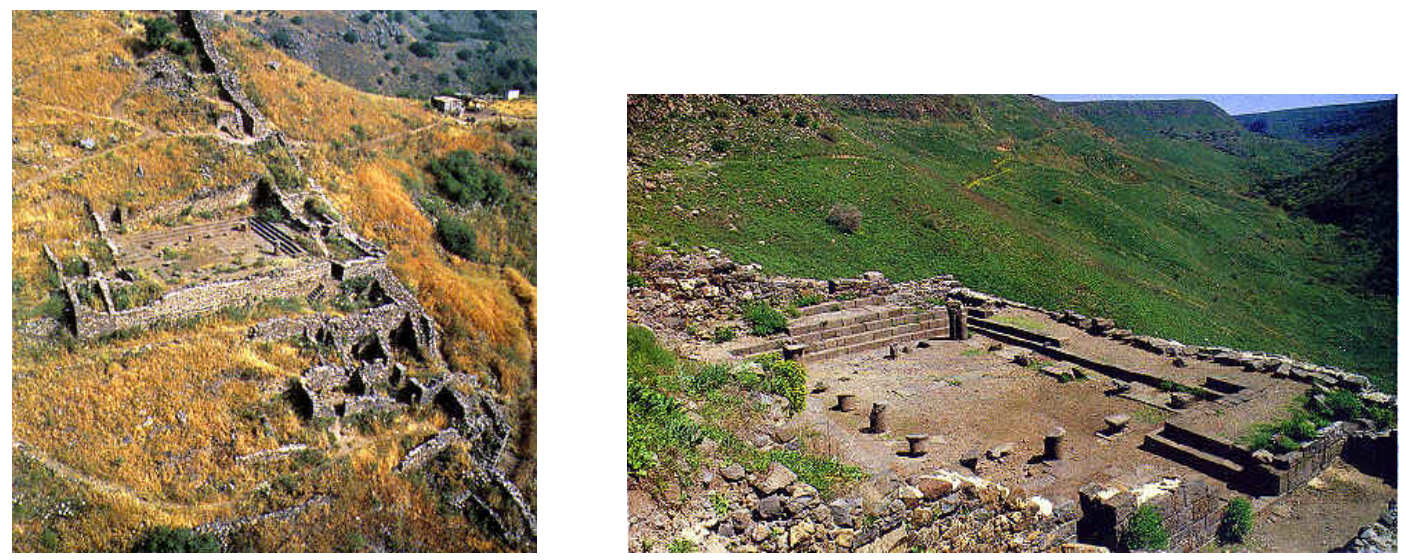

Figura 34: Imagens das ruínas da sinagoga de Gamla.

Fonte:<http://benwitherington.blogspot.com/2008/11/gamla-synagogue.html> Acesso em: 10 dez. 2010. 
A separação entre homens e mulheres na ordenação interna da sinagoga é um requisito adotado ainda hoje, principalmente nos edifícios ortodoxos. Entretanto, apesar da tradição judaica afirmar que esta separação foi um fato sempre presente na história das sinagogas, que tanto na sinagoga de Gamla, como nas de Massada, Delos e nas demais desse período nenhum traço de uma área separada para as mulheres foi encontrado (LEVINE, 2005).

O lugar da mulher na sociedade era primeiramente doméstico e esperava-se desta que permanecesse em casa, pois o setor público era em geral fechado a ela. Flavio Josefo, um historiador judeu e cidadão romano que viveu entre 38 d.C. e 100 d.C., explica que, conforme a lei judaica, a mulher era em todas as coisas inferior ao homem, não para sua humilhação, mas para que fosse direcionada, pois a autoridade foi dada por Deus ao homem (JOSEFO, 2004). Poder-se-ia, então, concluir que as mulheres não participavam das reuniões. Levine (2005), entretanto, afirma que as evidências literárias deixam clara que a presença das mulheres na sinagoga foi um fenômeno reconhecido e difundido ao longo da antiguidade e não há dúvidas de que nenhuma distinção havia na organização dos assentos entre homens e mulheres.

\subsection{Considerações}

Quanto ao programa de necessidades, as sinagogas desse período, edificadas na Palestina, são, em sua maioria, compostas apenas pelo salão de reuniões ou tem nesta sua ênfase maior. Nessa fase apenas o edifício em Delos apresenta um número razoável de outros cômodos, que, pelas condições dos achados arqueológicos, não puderam ser identificados. Entretanto, pela sinagoga de Delos ter sido edificada fora da Palestina, ela pode ter refletido em seu edifício as necessidades de uma comunidade exilada, onde determinadas funções, que não poderiam ser encontradas na localidade, precisaram ser agregadas ao edifício da sinagoga.

No que se refere à influência da localidade sobre os edifícios contemporâneos ao Templo de Jerusalém, tanto na Palestina quanto fora dela é possível identificar uma forte influência da cultura helenística. Pela presença do Templo, as sinagogas desse período na Palestina pareciam estar dispensadas da 
necessidade de carregar consigo um caráter sagrado, demonstrando um caráter primordialmente comunal.

Quanto à sua ordenação interna, estas sinagogas não apresentavam os elementos comuns às sinagogas contemporâneas, como a arca, a bimah ou um espaço separado para as mulheres. Entretanto o que vai se repetir nestes edifícios é o arranjo dos bancos voltados um para os outros, ideal para realização de reuniões coletivas. 


\section{DIÁSPORA}

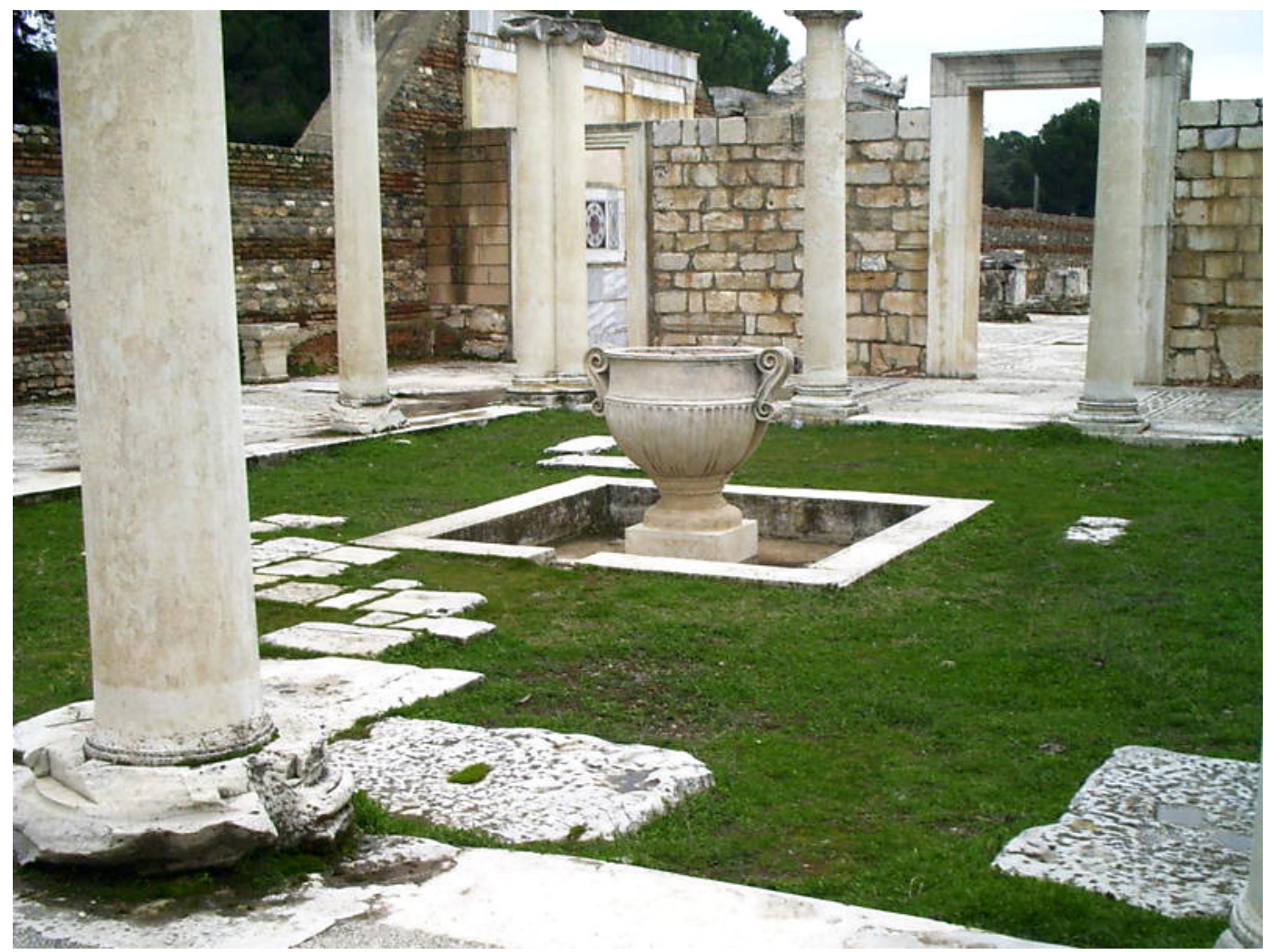

Figura 35: Pátio com fonte para purificação na sinagoga de Sardes. Fonte: <http://www.biblediscovered.com> Acesso em: 30 nov. 2010.

\subsection{Contexto Histórico}

O termo diáspora significa a "dispersão de um povo, de alguns dos seus elementos, de uma comunidade ${ }^{38 "}$ ou mais especificamente: "dispersão do povo judeu". A dispersão e o exílio vão acompanhar o povo judeu durante toda sua história, no êxodo do Egito, no cativeiro na Babilônia e, em 70 d.C., quando tropas romanas sob o comando do general Tito sitiaram Jerusalém até sua tomada e destruição. Até na atualidade, mesmo com a criação do Estado de Israel, milhares de judeus ainda permanecem espalhados entre as nações. Aqui o termo "diáspora" se refere à dispersão ocorrida em 70 d.C. A partir deste evento, essas comunidades se espalharam pela Europa e Norte da África, adaptando sua arquitetura às características e condições de cada região onde foram acolhidas. Em toda a

${ }_{38}^{38}$ Fonte: Dicionário Priberam de língua portuguesa: <http://www.priberam.pt/DLPO/> 
extensão do império romano, apesar de não oficial, o judaísmo era uma religião aceita e lícita, o que iria se alterar com as restrições impostas aos judeus a partir da ascensão do cristianismo. Nesse período, a sinagoga começou a se tornar o edifício central do judaísmo, pois, sem a existência do Templo de Jerusalém e da nação de Israel, a instituição assumiu o papel de mantenedora da identidade do povo judeu.

O próprio judaísmo começou a passar por transformações, assumindo novos significados. Com o fim do ministério levítico ${ }^{39}$, a religião judaica passou de uma prática hierárquica com um poder centralizado a uma realidade congregacional. É nesse momento que o período, aqui chamado "Diáspora", iniciase, findando por volta de 313 d.C. com o estabelecimento do cristianismo como religião tolerável no Império Romano.

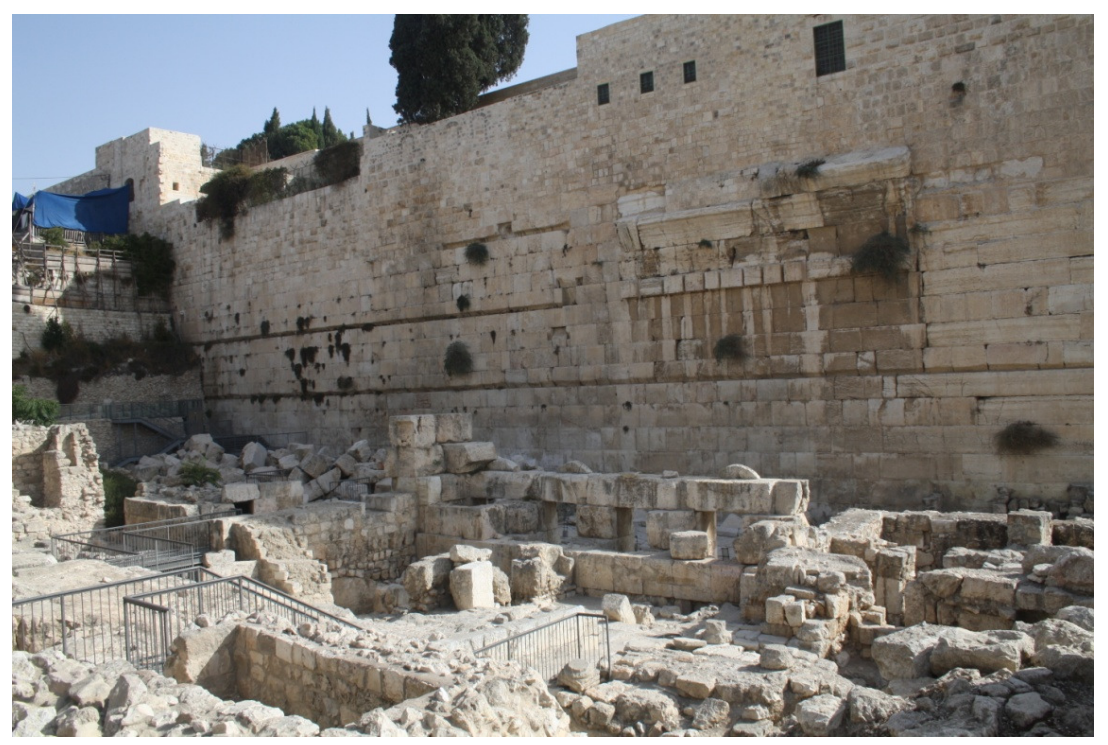

Figura 36: Ruínas do acesso oeste ao Templo em Jerusalém. Foto: Sergio Rugik Gomes.

Foram escolhidos três edifícios para a demonstração das transformações pelas quais a sinagoga passou durante esse período: Dura Europos, Síria - 245 d.C., Sardes, Turquia - 380 d.C., Ostia, Itália - Século IV d.C.

\subsection{Programa de Necessidades}

Devido às dificuldades provenientes das condições de exílio, a maioria das sinagogas desse período não passava de simples caixas retangulares.

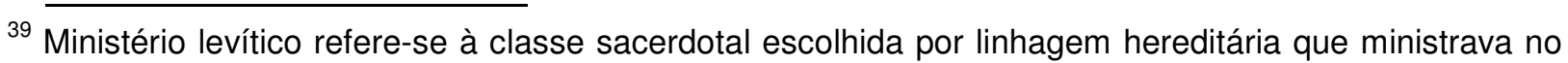
Templo de Jerusalém. 
Entretanto, em alguns lugares onde os judeus experimentaram condições melhores, foram erguidos edifícios com um design cuidadoso, executados com habilidade. Outros usos foram agregados aos edifícios visando atender às necessidades comunais dessas minorias exiladas (VOOLEN, 2004). É possível observar que o programa a essas sinagogas é mais complexo do que das encontradas na Palestina do período anterior, contemporâneo ao Templo de Jerusalém.

A sinagoga de Dura Europos, na Síria, foi descoberta em 1932, depois de amplas escavações realizadas pela Universidade de Yale e pelo departamento de antiguidades da Síria (LEVINE, 2005). Apesar de não ser possível definir suas funções, nela foi constatado uma segunda fase de construção onde uma série de cômodos foram anexados ao salão de orações (fig.37-38). O primeiro foi datado do final do segundo século segundo, ou princípio do terceiro. O segundo foi construído entre 244 d.C. e 245 d.C., atendendo um aumento significativo da comunidade, quando novas instalações foram agregadas ao complexo.

Um segundo edifício foi adquirido, integrado à estrutura original e submetido a profunda remodelação. A maior parte das funções, na segunda fase, passou a ser desempenhadas no novo edifício. Tanto na primeira como na segunda fase, o foco principal do edifício era o salão de reuniões, onde uma aedicula $a^{40}$ na parede oeste servia como santuário para a $\operatorname{Torah}^{41}$. Bancos se alinhavam nas quatro paredes do salão e pode ter havido algum tipo de $\operatorname{bimah}^{42}$ ou mesa ao centro (LEVINE, 2005).

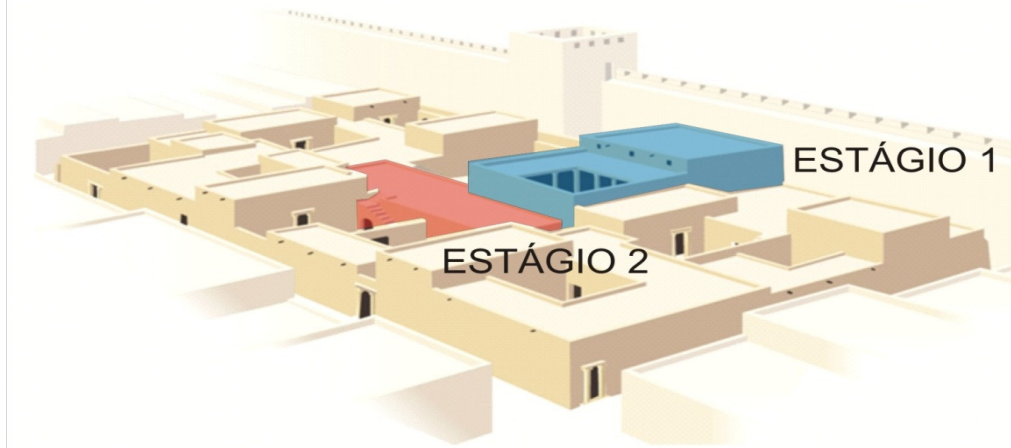

Figura 37: Reconstituição do conjunto de edifícios e sinagoga em Dura Europos. (destaque e comentários do autor).

Fonte: <http://commons.wikimedia.org/wiki/Category:Dura-Europos_synagogue> Acesso em: 30 nov. 2010.

\footnotetext{
${ }^{40}$ Estrutura tradicionalmente utilizada na arquitetura greco-romana com o propósito de abrigar deidades.

${ }^{41}$ Pergaminhos sagrados contendo os cinco primeiros livros do Tanah, o equivalente à bíblia cristã.

${ }^{42}$ Mesa de onde eram lidos os pergaminhos da Torah.
} 


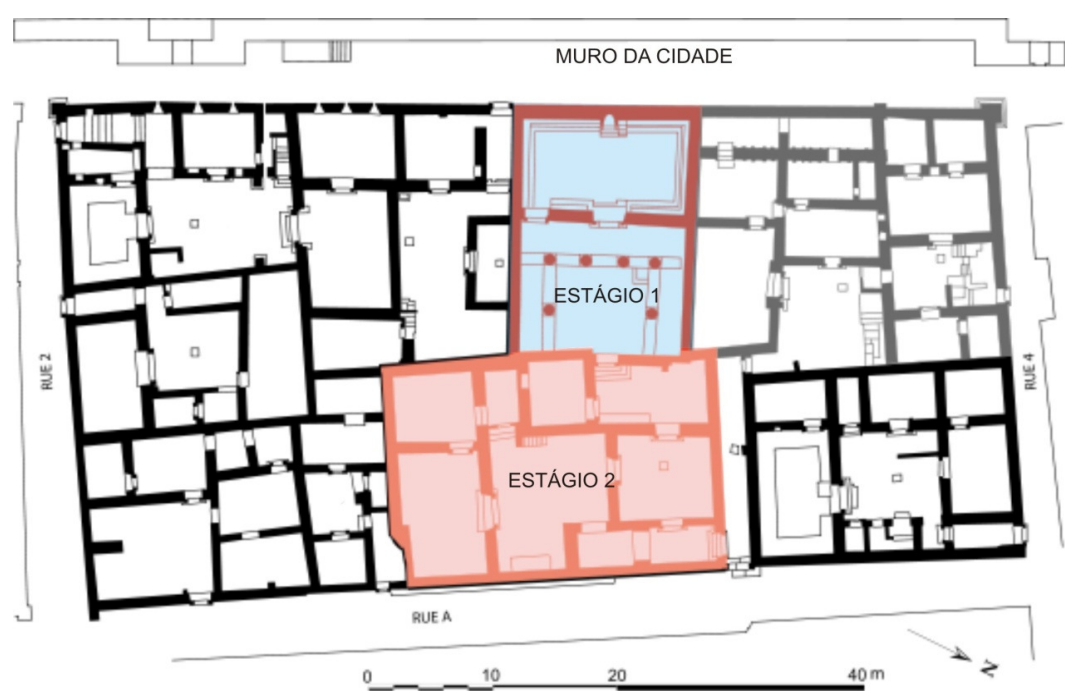

Figura 38: Planta da sinagoga de Dura Europos (edição e comentários do autor).

Fonte:<http://commons.wikimedia.org/wiki/File:Dura_Europos_L7_City_Block.svg> Acesso em: 13 dez. 2010.

Também na sinagoga de Ostia (fig.39), outros cômodos foram edificados junto ao salão de orações, com a diferença de que neste caso os achados arqueológicos permitiram a identificação de alguns deles. Ela foi escavada entre 1961-1962, mas apenas na última década é que se tornou foco de intensa pesquisa e debate. Localizada fora dos muros da cidade, a sinagoga foi construída próxima a um porto que além de Ostia servia à cidade de Roma. Ao norte, adjacente ao edifício, ficava a Via Severiana, uma importante artéria costal, construída por volta da virada do século terceiro. Suas ruínas, vistas hoje, datam do quarto e quinto séculos, entretanto os estágios anteriores alcançam o primeiro ou segundo séculos depois de Cristo. 


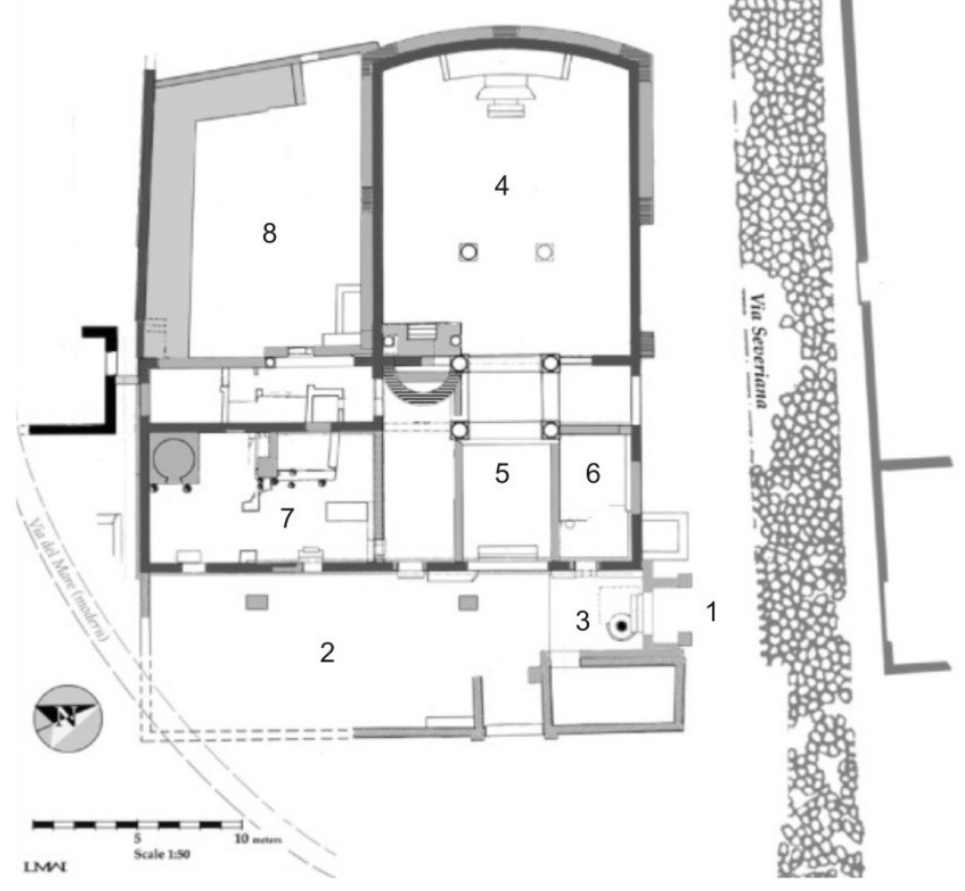

Figura 39: Planta da sinagoga de Ostia (edição do autor).

Fonte:<http://ostiasynagogue.wordpress.com/> Acesso em: 13 dez. 2010.

O conjunto todo mede $36,60 \times 23,50$ metros. A entrada pela Via Severiana (1) era flanqueada por duas colunas pequenas e levava a um longo vestíbulo (2), onde uma fonte e um poço (3) foram encontrados à esquerda da entrada. À direita, uma série de portas levava às salas principais, com as primeiras três entradas levando ao santuário (4). Essa entrada em três partes tinha uma grande porta central flanqueada por duas menores. Essa área (5) continha vários cômodos pequenos separados por paredes estreitas. Um cômodo à direita supostamente continha uma grande pia, talvez para servir a banhos rituais (6). Ao sul do salão principal estava uma cozinha (7) (fig.40) com um forno, uma mesa com tampo de mármore. Um grande cômodo (8) estava a oeste da cozinha, com bancos encontrados ao longo das paredes sudoeste e oeste da sala, sendo sugerido que possa ter servido como local de estudo, salão social, albergue e mais certamente como um triclinium ${ }^{43}$.

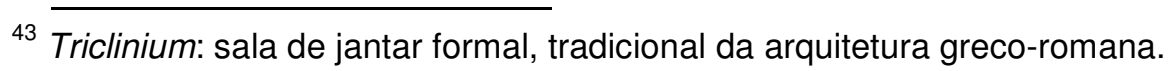




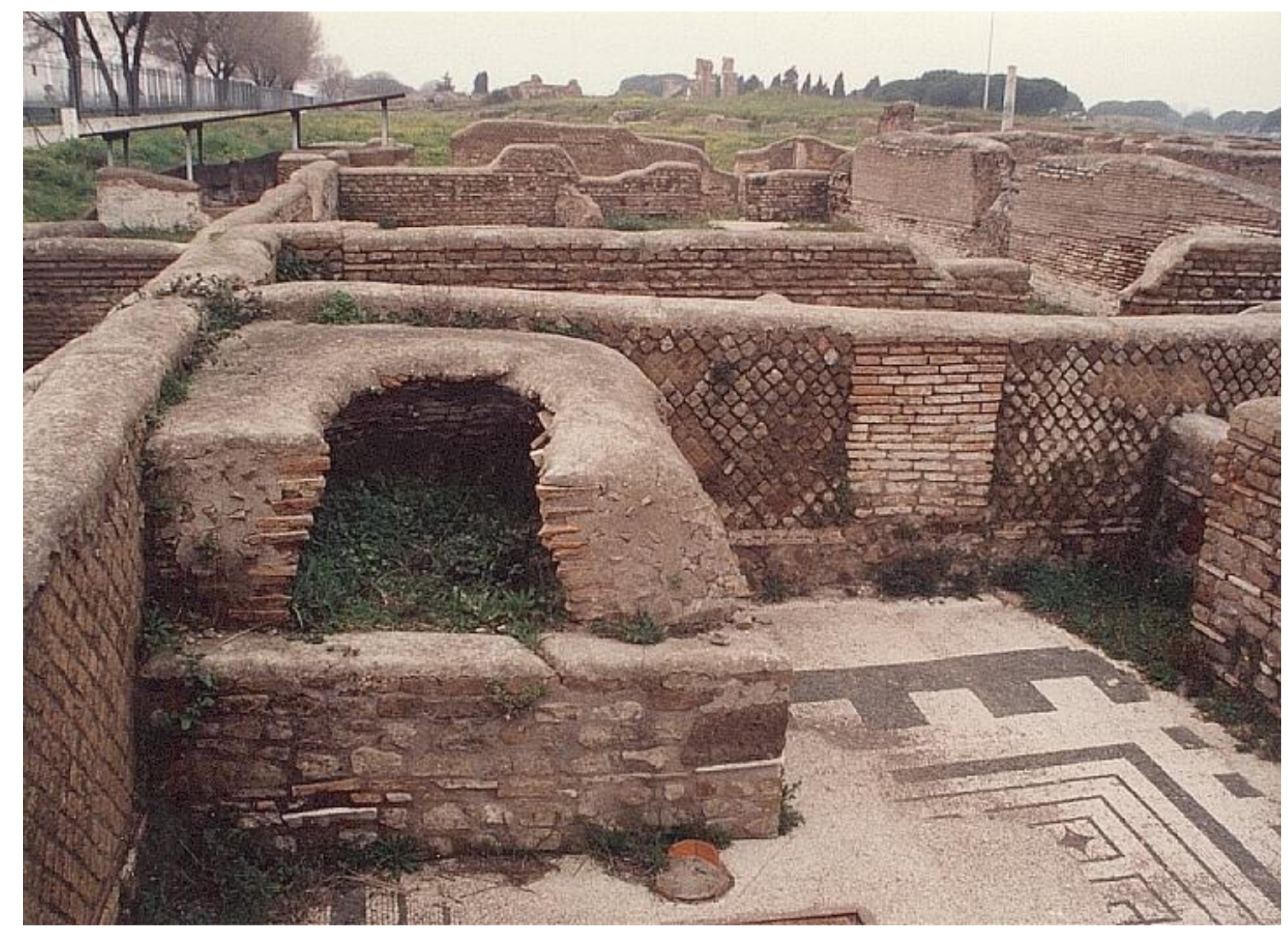

Figura 40: Vista da cozinha com forno na sinagoga de Ostia. Fonte:<http://catholicresources.org/AncientRome/ost12-8.jpg > Acesso em: 30nov. 2010.

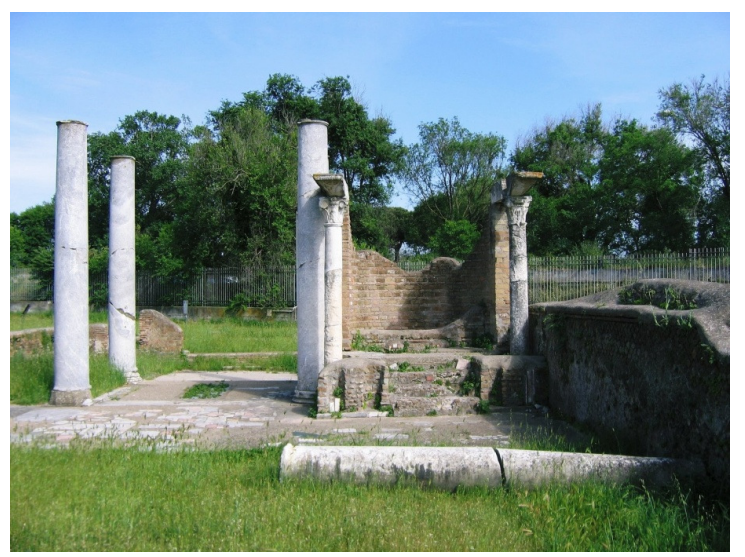

Figura 41: Entrada do salão principal com aedicula à direita e propylaeum à direita. Fonte: <http://picasaweb.google.com/lh/photo/d1JCUxGNtwXfcR45O7n3eg> Acesso em: 30 nov. 2010.

A porta central dava acesso ao salão principal, com $15 \times 12,50$ metros, por meio de dois pares de colunas, tipo propylaeum ${ }^{44}$ (fig.41), chegando à

44 Propylaeum: pórtico sustentado por colunas que precedia recintos sagrados, tradicionalmente utilizados na arquitetura greco-romana. 
altura de 4,70 metros. Uma bimah, ou pódio, foi erguida ao longo da parede extrema, levemente encurvada à oeste do salão principal. Logo ao sul do propylaeum, em um pódio estava uma grande aedicula (fig.41) onde possivelmente se guardavam os rolos da Torah.

\subsection{Influência da Localidade}

A cidade antiga de Ostia foi extensivamente explorada pelas atividades arqueológicas. Isto contribuiu para que pudessem ser estabelecidas relações entre a arquitetura da sinagoga e de seu contexto urbano (fig.42). As atividades de tais associações envolviam culto, banquetes e reuniões. Os edifícios corporativos maiores tinham um peristilo ${ }^{45}$, ou santuários para adoração aos deuses, em salas adjacentes. A viabilidade de água era um importante pré-requisito para tais grupos. Poços, cisternas, e lavatórios podiam ser encontrados em todos os lugares. A sinagoga, como visto, tinha instalações similares.

Levine (2005) afirma que, dada a amplitude da presença de diferentes corporações nesta cidade portuária, não é de surpreender que a comunidade judaica local foi influenciada por elementos das estruturas das proximidades, assim como das atividades corporativas, e as adaptaram dentro de suas próprias necessidades. Entretanto alguns elementos podem ter sido originalmente inspirados no Templo de Jerusalém. Talvez pela necessidade da identidade, ou devido ao contexto religioso politeísta, pode ter levado essas comunidades a buscar no Templo referências que, em seu próprio ponto de vista, imprimissem um caráter sagrado à sinagoga.

${ }^{45}$ Peristilo: pátio retilíneo avarandado, circundado por colunas, tradicionalmente utilizado na arquitetura greco-romana. 


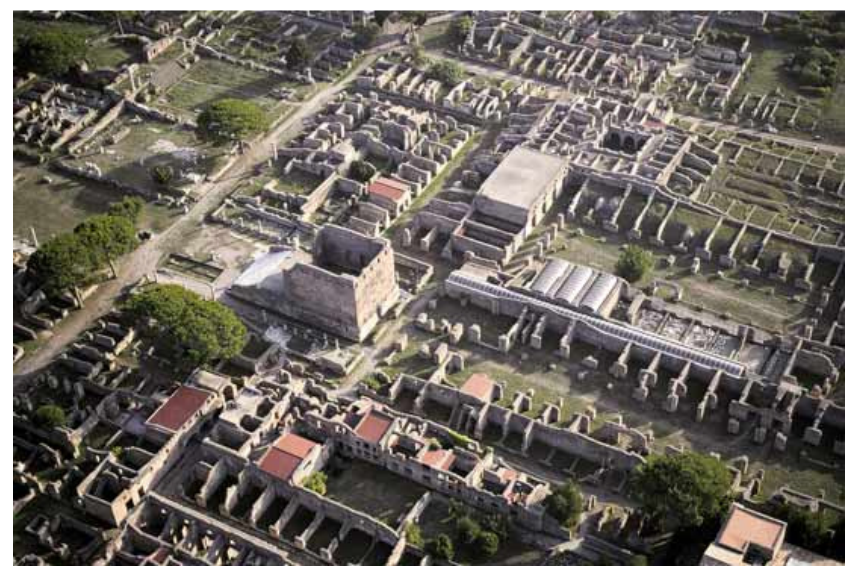

Figura 42: Vista aérea do contexto urbano de Ostia.

Fonte: <http://www.topromantours.com/tours.htm> Acesso em: 30 nov. 2010.

Em Sardes, uma importante cidade da antiguidade a oeste da atual Turquia, a comunidade judaica parece ter tido uma relação bem próxima com a sociedade onde se inseriu. Descoberta em 1962, sua sinagoga tem atraído a atenção de uma grande porção de eruditos, e sua estrutura é a mais monumental de todas as sinagogas antigas (LEVINE, 2005). Ela está enraizada em uma área proeminente, localizada na rua principal de um cruzamento importante, implantada em uma das asas da palaestra ${ }^{46}$ da cidade (fig.43). Do lado de fora da parede sul, de frente para a rua principal, o edifício era faceado por uma fileira de lojas. Uma entrada lateral conectava essas lojas diretamente ao átrio da sinagoga.

46 Palaestra: Campo cercado e descoberto destinado a práticas esportivas, utilizado durante a antiguidade romana. 


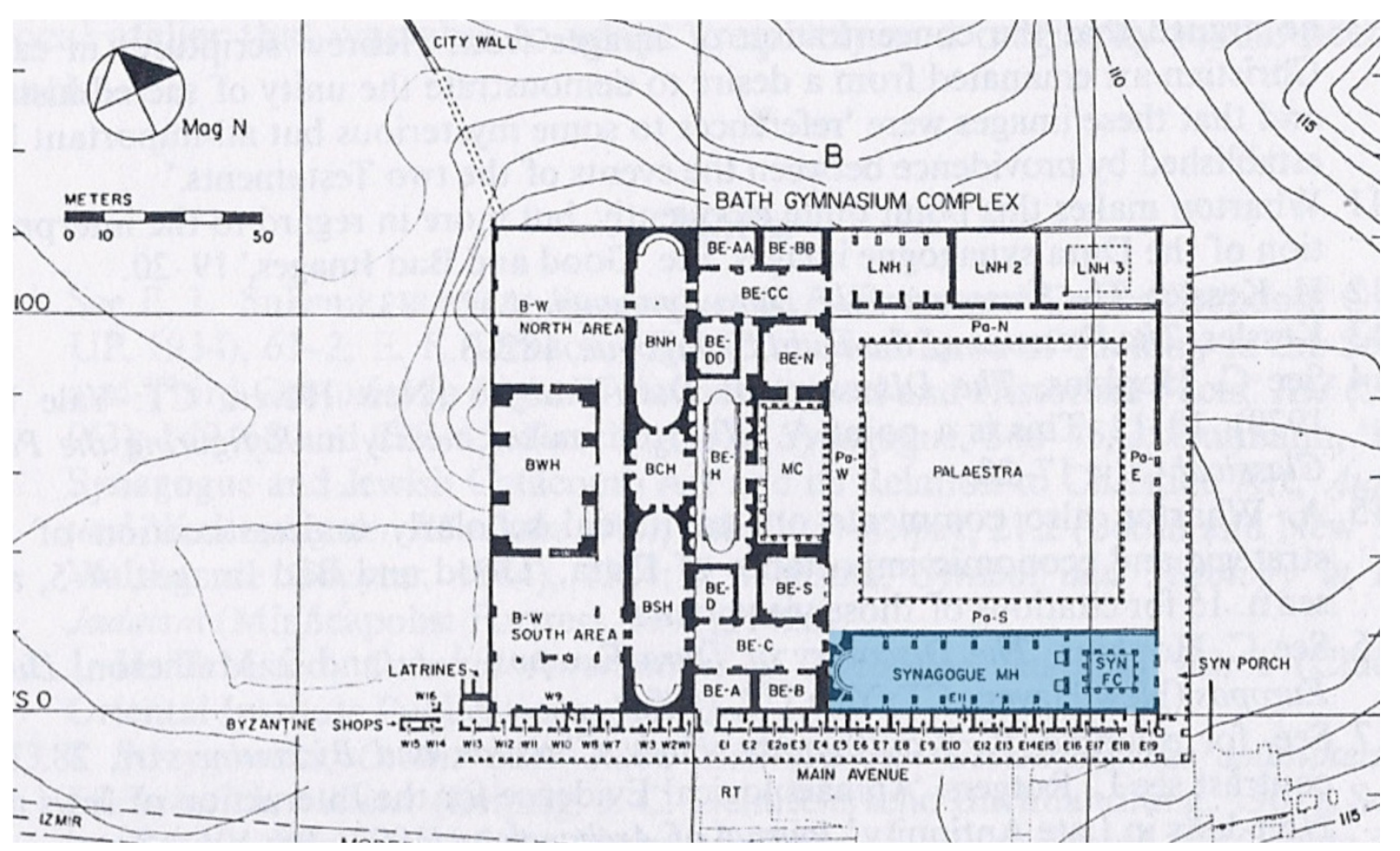

Figura 43: Planta do complexo e sinagoga de Sardes com destaque para a sinagoga (edição do autor). Fonte: Fine, 1999.

O edifício (fig.44-45) tem 80 metros de comprimento, e em seu último estágio, ele foi dividido em duas partes, um santuário com quase 60 metros de comprimento e um átrio com 20 metros. A palaestra foi completada em algum momento do segundo século d.C. e servia como um imenso gymnasium ${ }^{47}$ e complexo de banhos. O lado sul do complexo, como seu equivalente ao norte, era dividido em uma série de salas que aparenta ter funcionado como salas de vestir ou de exercícios, cada uma abrindo-se à palaestra. Quando essa área se converteu em uma basílica cívica, suas partes internas foram removidas e as entradas fechadas, e uma nova entrada foi feita pela rua à leste. O edifício tinha um pátio de entrada (fig.35) à leste e uma exedra ${ }^{48}$ com nichos para estátuas de deidades ou imperadores à oeste (fig.47), tendo servido a algum propósito cívico nesse tempo.

No estágio seguinte, que data da segunda metade do século terceiro, o edifício foi claramente ocupado pela comunidade judaica. A parede que separa o salão principal e o átrio foi removida para criar um cômodo com 80 metros de comprimento. Em seu final à oeste, três bancos semicirculares enfileirados foram construídos e a exedra foi transformada em um abside para sentar-se. De acordo

${ }^{47}$ Gymnasium: local para a prática de esportes, socialização e atividades intelectuais, utilizado durante a antiguidade romana.

${ }^{48}$ Exedra: recesso semicircular, geralmente resultante da composição de uma fachada na arquitetura greco-romana. 
com os escavadores, os bancos semicirculares poderiam acomodar até setenta pessoas (LEVINE, 2005).

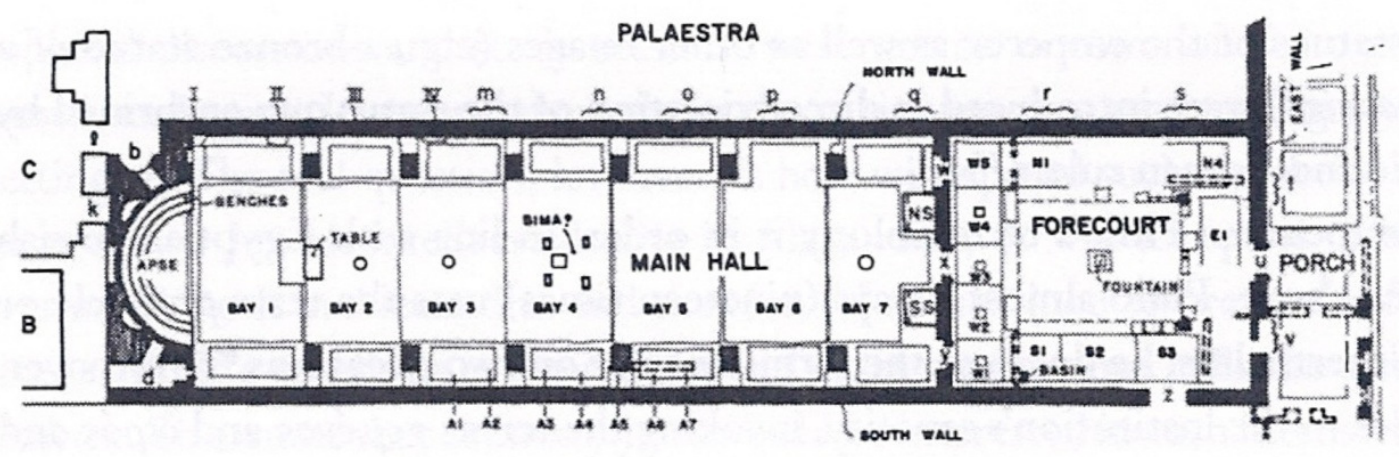

Figura 44: Planta da sinagoga de Sardes. Fonte: Levine, 2005.

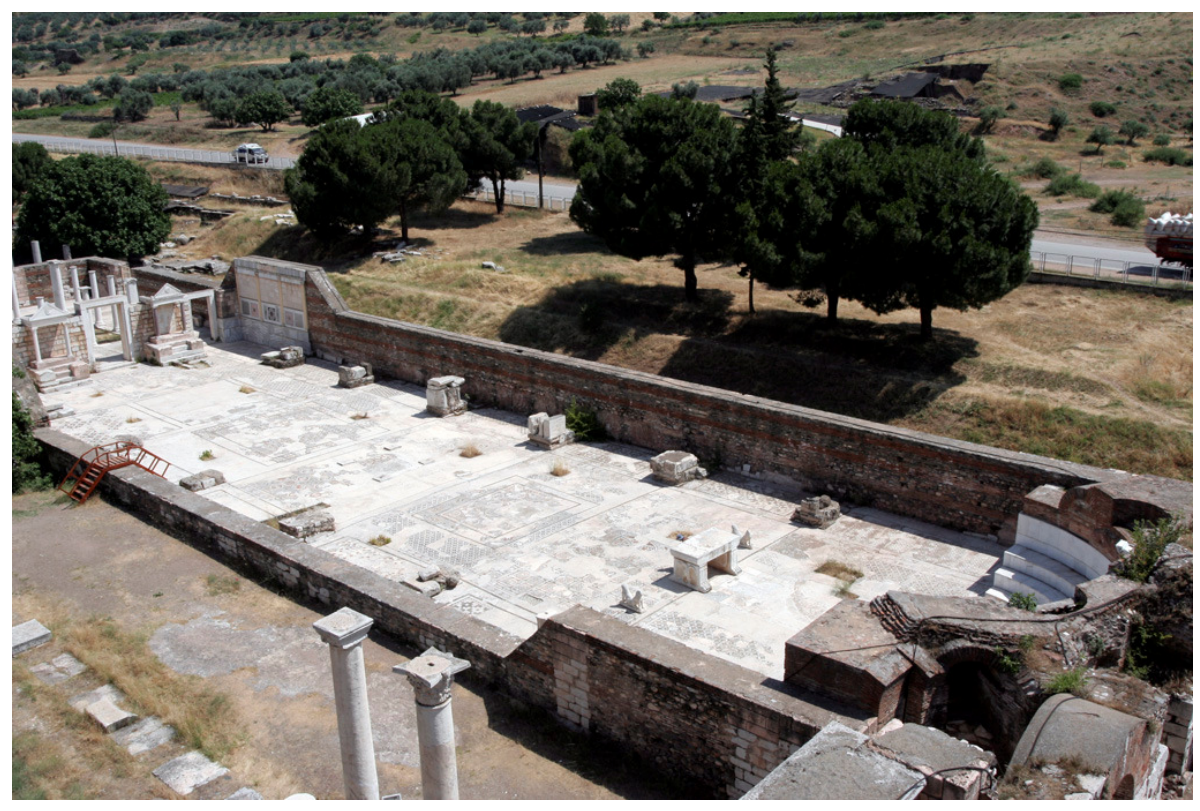

Figura 45: Vista do corpo da sinagoga de Sardes. Fonte: <http://sitemaker.umich.edu/lateantiquity/files/sardissyn.jpg> Acesso em: 30 nov. 2010.

A sinagoga revelada pelas escavações foi construída em meados do século quarto. O átrio foi completado por volta de 360-380 d.C. O salão principal figura com suas colunas e mosaico elaborado no piso, na segunda metade do século quarto. Aqueles que atendiam à sinagoga acessavam o átrio por alguma das ruas ao leste ou sul. O átrio era grande e atraente, com pórticos rodeando um grande pátio aberto ricamente decorado com um piso de mosaico colorido e de padrões geométricos (fig.46). 


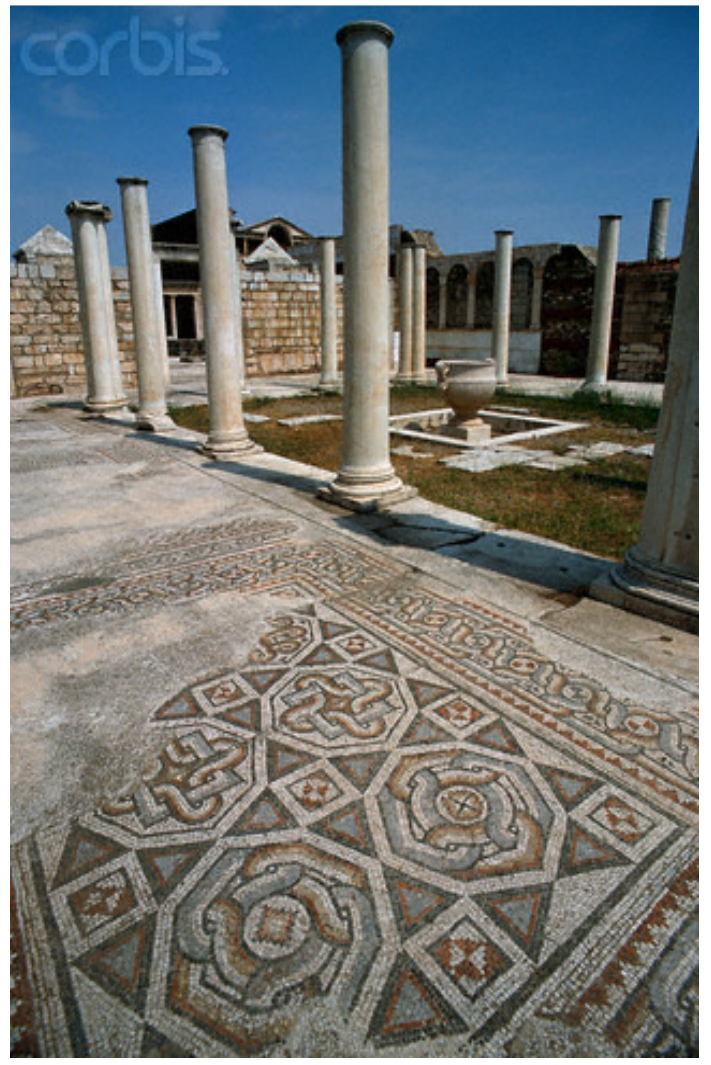

Figura 46: Átrio da sinagoga de Sardes.

Fonte: <http://www.corbisimages.com/Enlargement/VN004588.html> Acesso em: 14 dez. 10.

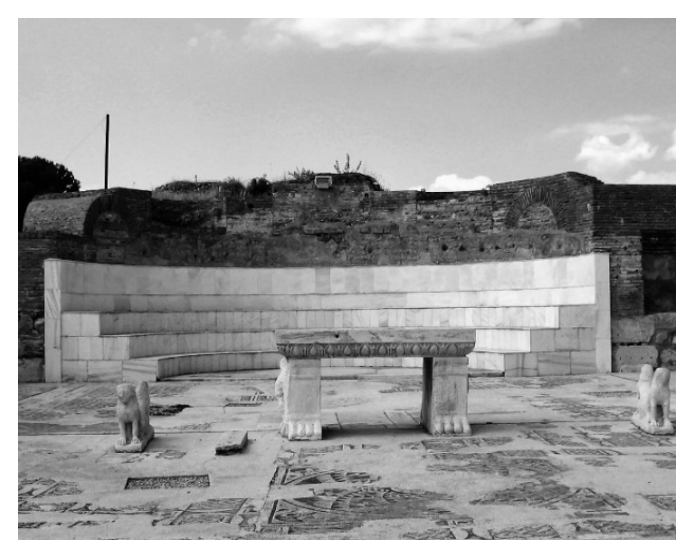

Figura 47: Exedra aos fundos da sinagoga de Sardes. Fonte: <http://www.sbhseattle.org/> Acesso em: 30 nov. 2010.

Três portais, uma porta central flanqueada por duas menores conduzem do átrio exterior para o santuário principal. Imediatamente no interior ao santuário, duas aedicula ${ }^{49} \mathrm{em}$ pedra talhada ficam na parte posterior da entrada principal (fig.48). Uma delas, a ao sul, era de melhor qualidade e possivelmente continha a arca da Torah e pergaminhos. A função da segunda permanece

${ }^{49}$ Aediculae: Plural de aedicula. 
desconhecida, para pergaminhos adicionais ou possivelmente uma réplica da menorah $^{50}$, pode ter sido mantida lá. Em caráter alternativo, ela pode ter servido como assento para o ancião ou para algum outro oficiante, embora isto pareça improvável, dado o fato de que havia bancos na abside do lado oposto do salão.

Como era o caso em sinagogas de outras localidades, as pedras utilizadas nessas aediculae vinham originalmente de edifícios pagãos da cidade, cujos assentos se destinavam a pessoas de renome. Pilares dividiam a nave central em duas fileiras de cada lado do salão principal. Como não havia nenhum indício de um balcão ou bancos de pedra, a congregação, estimada em torno de mil pessoas, provavelmente se sentava em esteiras ou bancos de madeira. Na direção da parede oeste ficava uma maciça mesa de mármore, chamada de "mesa da águia" por causa de duas grandes águias romanas gravadas em relevo em cada uma das duas pedras de sustentação. Por trás da mesa, havia dois pares de leões sentados de costas um para o outro.

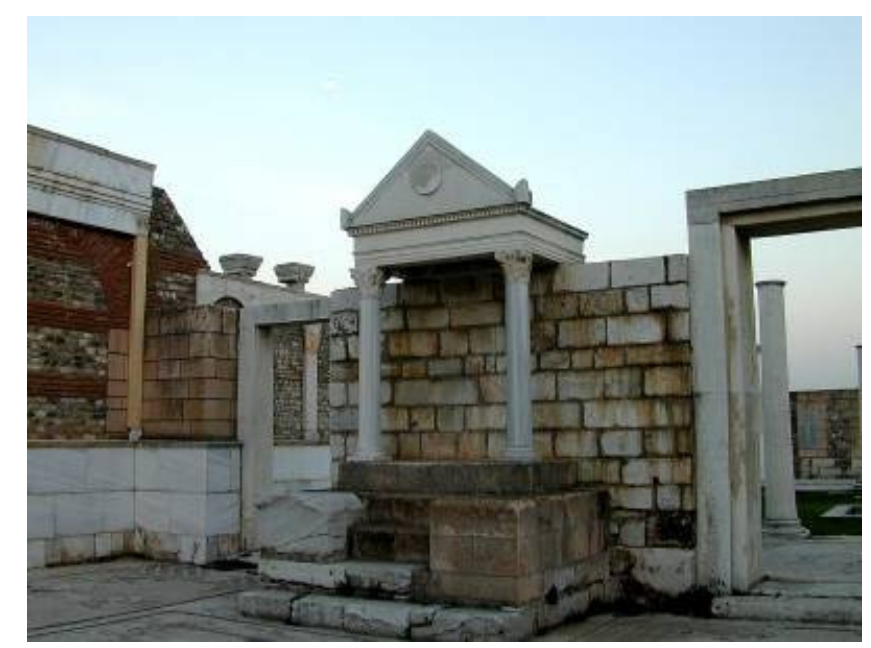

Figura 48: Santuários da Torah em Sardes. Fonte: <http://www.bibleplaces.com/sardis.htm> Acesso em: 30 nov. 2010.

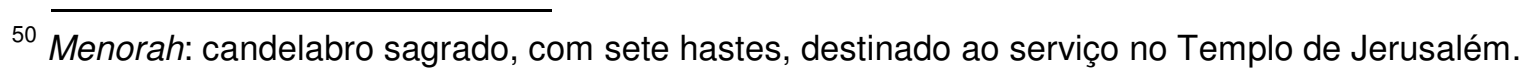




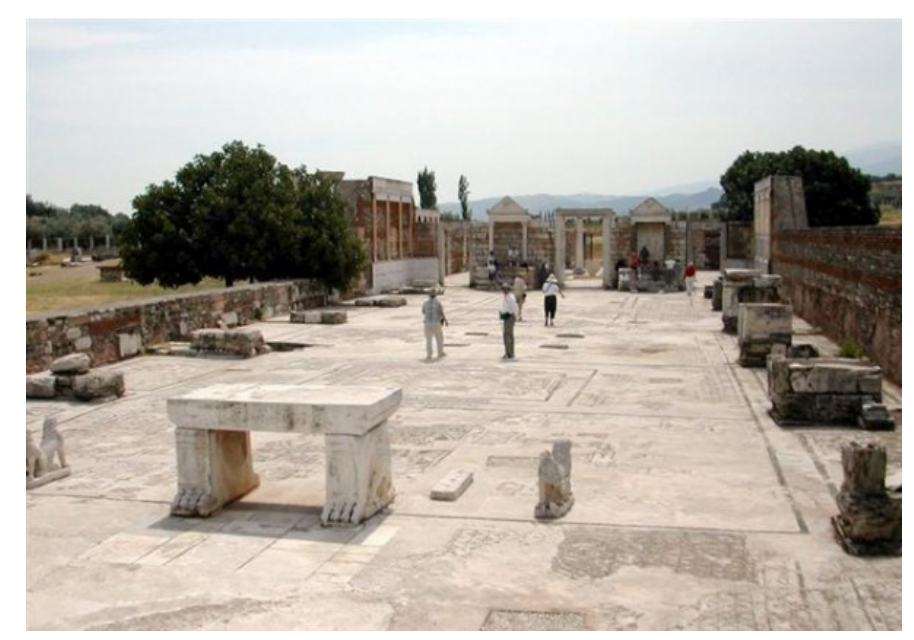

Figura 49: Salão de orações da sinagoga de Sardes.

Fonte: <http://www.turkeyinphotos.com/photos/sardis/> Acesso em: 14 dez. 2010.

Levine (2005) afirma que achados da sinagoga de Sardes colocaram em pauta muitas das suposições negativas das gerações passadas com relação ao estilo da vida judaica das sinagogas da diáspora da antiguidade tardia. Segundo ele, essas sinagogas têm demonstrado que ao menos algumas comunidades tinham atingido um alto grau de reconhecimento e status dentro de suas próprias cidades. No caso de Sardes, essa posição privilegiada continuou por muitos séculos até a cristianização do império e finalmente com a destruição da cidade pelos persas em 616 d.C.

Em sua aparência, Sardes provavelmente seguia o estilo dos edifícios romanos (fig.50). Era comum para uma comunidade minoritária adotar as características culturais da maioria. A sinagoga de Ostia também seguiria o mesmo princípio (fig.50). Tanto em Ostia como em Dura Europos ou Sardes, os santuários da Torah, construídos como uma aproximação clara das aediculae (fig.48), são um bom exemplo de como a sinagoga absorveu a influência dos elementos da arquitetura local. Nos templos pagãos ou residências, a função das aediculae era abrigar os ídolos, mas na sinagoga elas foram utilizadas para hospedar os pergaminhos sagrados. 

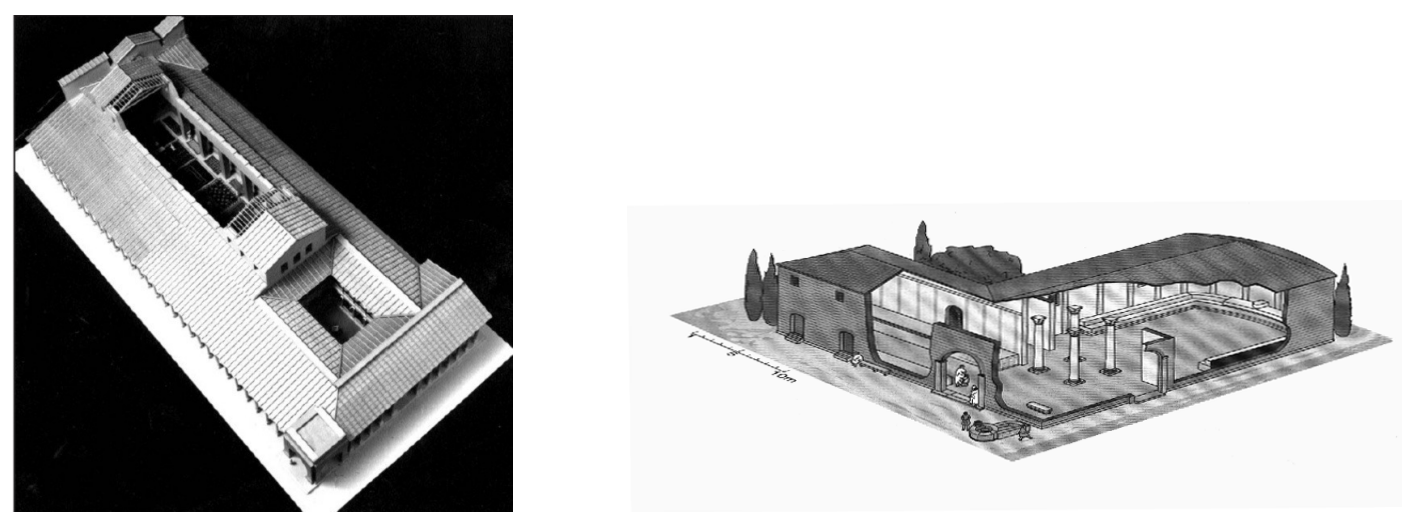

Figura 50: Reconstituição das sinagoga de Sardes e Ostia. Fonte: Fonte: FINE, 1999. <http://www.pohick.org/sts/images/ostia3d.gif> Acesso em: 30 nov. 2010.

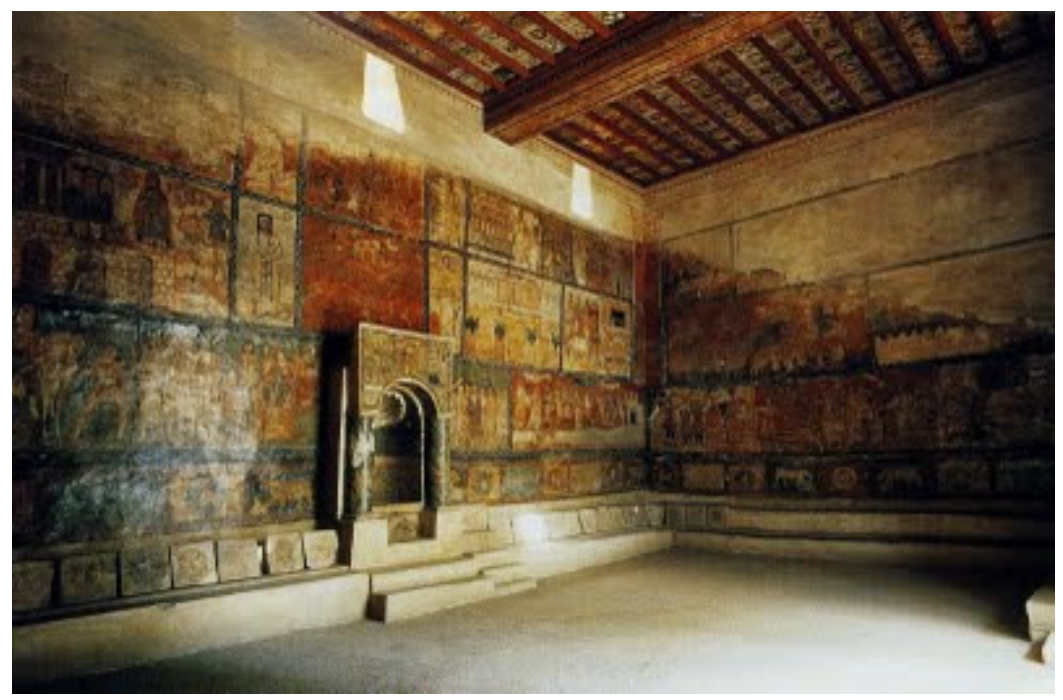

Figura 51: Detalhe da parede oeste com aedicula.

Fonte: <http://2.bp.blogspot.com/_CijcaA9yq58/SomavkZI2TI/AAAAAAAADMw/T6XUai3WWYs/ s400/Dura+Europos+Synagogue.jpg >; Acesso em: 30 nov. 2010.

Outra evidência da influência local é a utilização de imagens figurativas. O judaísmo é uma religião conhecidamente iconoclasta devido às determinações da Torah. Entretanto, nas sinagogas de Dura Europos e Sardes, as imagens figurativas foram largamente utilizadas tanto em afrescos como esculpidas em pedra, o que não puderam ser identificadas na maior parte das sinagogas do período anterior ou posteriores (fig.52). A cultura greco-romana utilizava a aplicação de imagens figurativas com abundancia. Os judeus desse período encontraram uma forma de conviver com esse contexto e adaptaram sua decoração à utilização de imagens, consideradas apenas como decoração e não como idolatria. Kinsky (1996) afirma que "aparentemente, os judeus do Império Romano tardio eram capazes de diferenciar suas próprias imagens dos ídolos que os cercavam na sociedade pagã." 

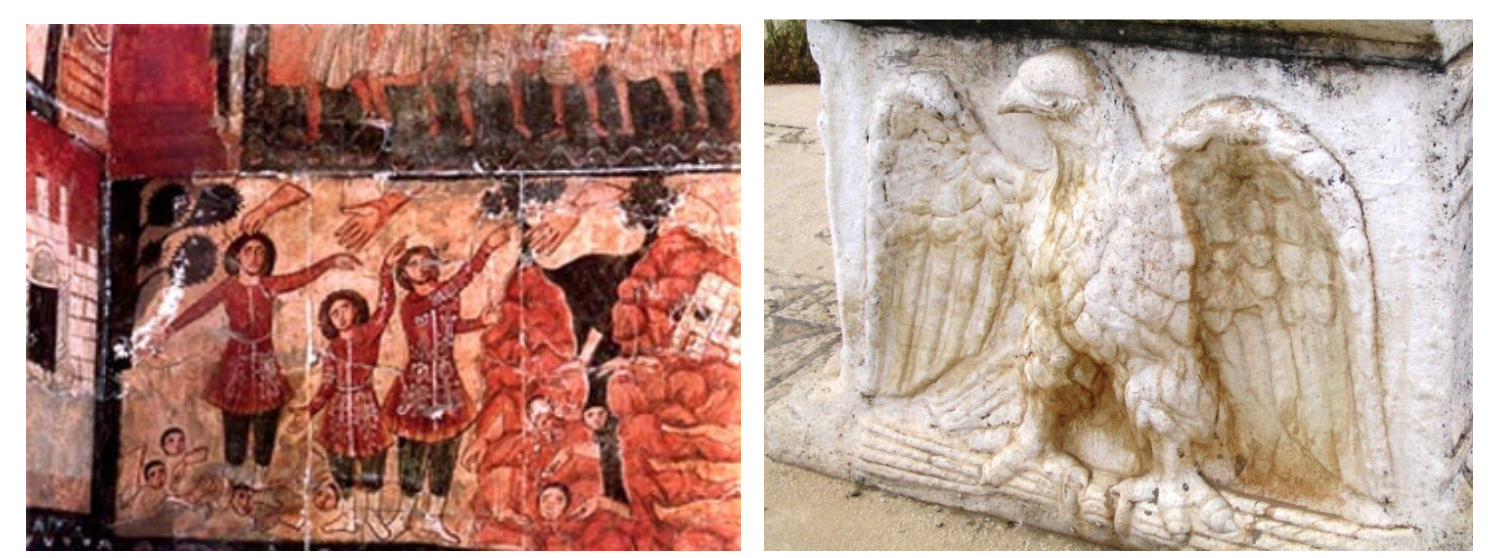

Figura 52: Imagens utilizadas nas sinagogas de Dura Europos e Sardes. Fonte: <http://arthistorymadness.blogspot.com/2007/10/dura-europos.html> Acesso em: 30 nov. 2010.

Fonte: <http://picasaweb.google.com/lh/photo/re8LRUt7tvWdawpkyFJA0g> Acesso em: 30 nov. 2010.

\subsection{Ordenação Interna}

Quanto à ordenação interna dos edifícios posteriores à diáspora, começam aqui a surgir os primeiros sinais da presença da bimah, como uma plataforma elevada em Ostia ou a mesa de Sardes. A arca aparece nesse período na forma das aediculae, presente nos três exemplos desse período. Entretanto o arranjo destes elementos parece não seguir um padrão comum, variando de um edifício para outro. Em Sardes e Ostia, as aediculae estão orientadas à leste, porém junto à parede de entrada do salão de orações, enquanto que em Dura Europos esta fica junto à parede oposta à entrada. Em Dura Europos, a aedicula fica orientada à oeste e não à leste como rege a lei judaica. Talvez apenas a partir da idade média, com a divulgação dos tratados dos sábios judeus sobre as novas formas de se vivenciar a religião sem o Templo, é que tais normas tenham sido assumidas por grande parte das comunidades.

Quanto à separação entre homens e mulheres, assim como nos edifícios contemporâneos ao Templo, as sinagogas desse período também não trazem consigo nenhuma evidência que comprove a existência de algum lugar específico para as mulheres. Pode-se supor assim que nessas comunidades da diáspora não havia nenhum tipo de separação entre os sexos.

\subsection{Considerações}


Quanto ao programa das edificações, observa-se assim que, neste período subsequente à diáspora de 70 d.C., as sinagogas agregaram a si funções que visavam atender necessidades específicas de comunidades exiladas, necessidade que possivelmente não poderiam ser atendidas na localidade.

No que se trata da influência da localidade sobre essas sinagogas, é Interessante observar que, no caso específico da sinagoga de Sardes, esta estava intimamente ligada ao estilo de vida da cidade, bem como sua comunidade devia ter grande inserção na sociedade. Isto pode explicar porque tantos elementos da arquitetura local puderam ser encontrados na sinagoga. A utilização das imagens figurativas, do uso das aediculae para armazenamento da Torah e a provável forma exterior das sinagogas deste período, são exemplos concretos dessa influência.

Quanto à ordenação interna dos edifícios desse período, estes parecem não seguir uma ordenação interna ou orientação pré-definida. A bimah e a arca começam a aparecer nesse momento, entretanto sem uma ordenação comum e ainda sem um espaço específico para as mulheres. 


\section{A ASCENSÃO DO CRISTIANISMO}

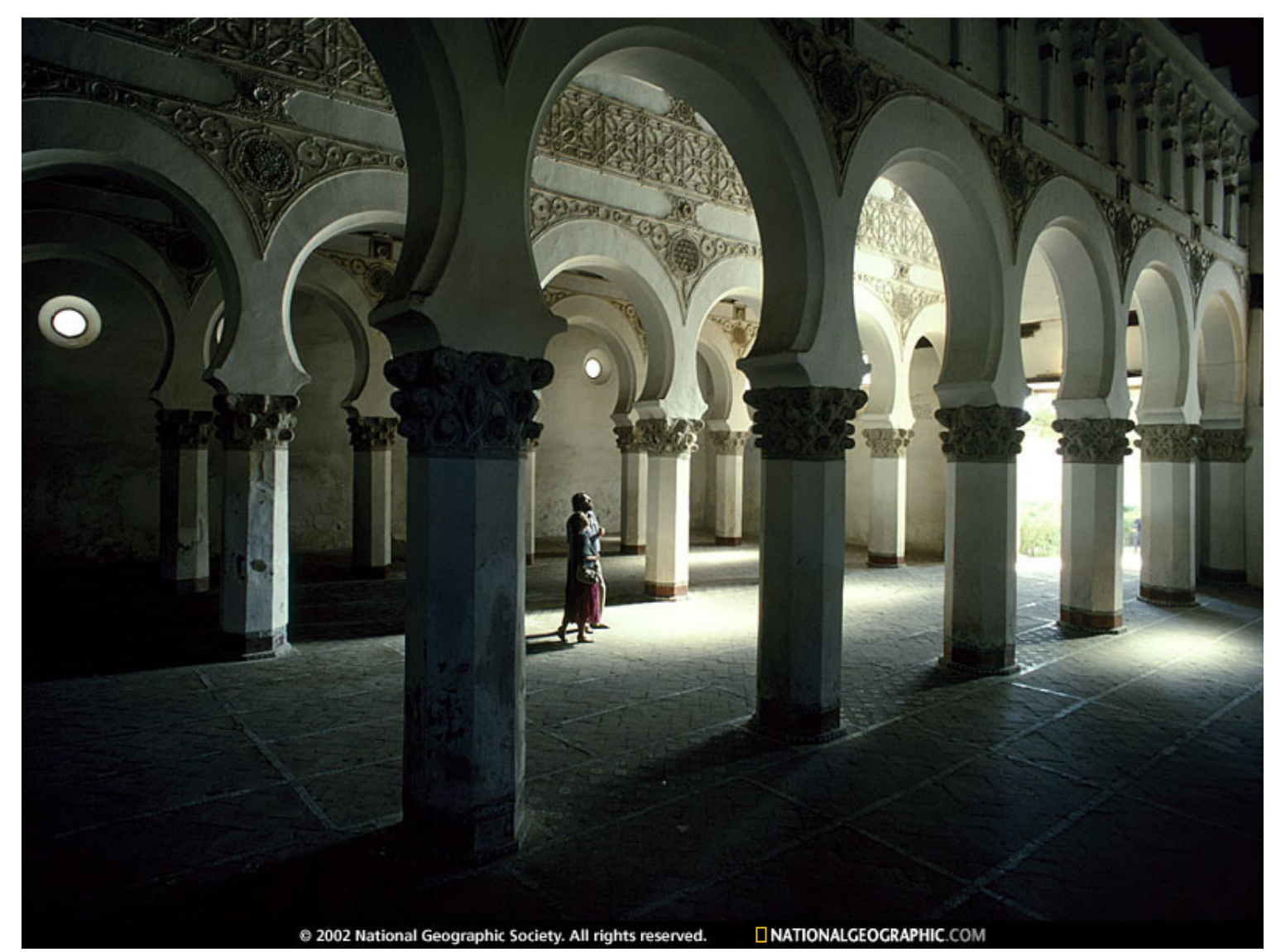

Figura 53: Interior da sinagoga "Santa Maria La Blanca" em Toledo, Espanha. Fonte: $<$ http://photography.nationalgeographic.com/photography/enlarge/santa-maria-la-

blanca_pod_image.html> Acesso em: 16 dez. 2010.

\subsection{Contexto Histórico}

O cristianismo cobre um longo período de tempo. Esta fase se inicia no século IV por ocasião do reconhecimento do cristianismo como religião tolerável no Império Romano e se encerra apenas no século XVIII, quando começa o processo de emancipação dos judeus na Europa. A opressão sofrida pelas comunidades judaicas foi a principal característica desse período. Em 385 d.C., sob o comando de Constantino, o império romano torna o cristianismo sua religião oficial. Até esse momento as sinagogas mantinham certo status como edifícios religiosos, gozando de proteção legal contra ocupações, roubos ou taxações.

Entretanto, considerados inimigos de Cristo pela nascente igreja Católica, os judeus começaram a sofrer uma sistemática segregação através do estabelecimento de diversas restrições civis. A partir desse momento, uma série de 
leis segregatórias foi promulgada, começando com a proibição da celebração das festas judaicas pelos cristãos, como a Páscoa e o Shabat ${ }^{51}$, até o confisco de sinagogas para transformá-las em igrejas, a proibição da posse de terras e da construção de novas sinagogas, inclusive de se habitar dentro das cidades muradas.

Em 565 d.C., com a separação definitiva do Império Romano do ocidente e do oriente, inúmeros governos locais surgiram no ocidente, sujeitando os judeus a diversas leis locais, tornando sua condição ainda menos favorável. Entre os séculos IV e X a grande maioria das comunidades judaicas não teve condições de construir uma sinagoga, utilizando espaços alternativos adaptados para tal. Do século $\mathrm{X}$ em diante os judeus foram alvo de diferentes formas de violência $\mathrm{e}$ perseguição, como a expulsão dos judeus da Espanha em 1492, o massacre de milhares de judeus de Lisboa em 1506 (Wiznitzer, 1960) ou os pogroms russos do final do século XVIII (MARONI, 2005).

Além desse quadro, outro fator importante desse período foi a maior aceitação da lei judaica, mais especificamente do Talmud. A destruição do Templo e da cidade de Jerusalém em 70 d.C. causou uma catastrófica transformação no estilo de vida dos judeus. Era necessário que novos entendimentos se fizessem sobre a religião e sua prática, agora sem o serviço sacerdotal ${ }^{52}$ do Templo. Novas figuras deveriam assumir o papel de autoridade religiosa para o povo judeu. Conselhos de sábios foram formados para estabelecer os novos parâmetros pelos quais a religião deveria ser praticada. Diferentes rabinos e conselhos de rabinos foram formados ao longo dos séculos, cujos registros de suas conclusões, sobre a lei oral ${ }^{53}$ e suas atualizações, deram origem ao Talmud e influenciaram a arquitetura das sinagogas, especialmente a partir do século XVII (PARSONS, 2010).

Para a demonstração das transformações ocorridas nesse período, foram selecionados os seguintes edifícios: Sinagoga de Worms, Alemanha - 1174, Sinagoga "Santa María la Blanca" em Toledo, Espanha - Sec.XIII, Sinagoga Scuola Grande Tedesca em Veneza, Italia - 1733, Sinagoga de Lancut - Séc. XVII(?).

\subsection{Programa de Necessidades}

${ }^{51}$ Shabat refere-se ao sétimo dia da criação, onde não é permitida a realização de qualquer trabalho.

${ }^{52}$ Serviço sacerdotal diz respeito ao ofício dos sacerdotes no Templo de Jerusalém.

${ }^{53}$ A lei judaica é composta da lei escrita e da lei oral. 
Como não era permitida aos judeus a posse das terras onde estavam edificadas as sinagogas, estas eram construídas de forma modesta, prevendo um possível cancelamento da permissão de uso, ficando ao proprietário das terras. Além disso, as sinagogas eram edificadas em áreas destinadas especificamente aos judeus, que não podiam habitar dentro das cidades ou eram destinadas à áreas próximas aos muros, que, segundo Krinsky (1996), por serem mais sujeitas a invasões, seus lotes eram menos valorizados. Nessas áreas não havia muito espaço disponível, e a maior parte das sinagogas tinha de ser adaptada a edifícios existentes. Sendo assim, em sua maioria, essas sinagogas eram retangulares e de dimensões reduzidas, proporcionais também às pequenas populações judaicas (KRINSKY, 1996).

Diante das condições restritivas em que se encontravam, os judeus tenderam a um isolamento da ordem social majoritária. Apesar do isolamento, as ruas, quarteirões ou guetos dos judeus tornaram-se uma opção onde seria possível viver de acordo com a lei e os costumes judaicos. Por questões de segurança e para manutenção de seus costumes, as comunidades procuravam viver próximas a uma sinagoga e a outros judeus. Em Veneza, Itália, os judeus tiveram de ocupar um gueto separado do restante da cidade, isolado pela água por todos os lados (fig.54). A sinagoga Scuola Grande Tedesca (fig.55) foi construída neste gueto em 1529. Como havia pouco espaço disponível, ela foi instalada no quarto e quinto andares de um edifício existente (fig.57).

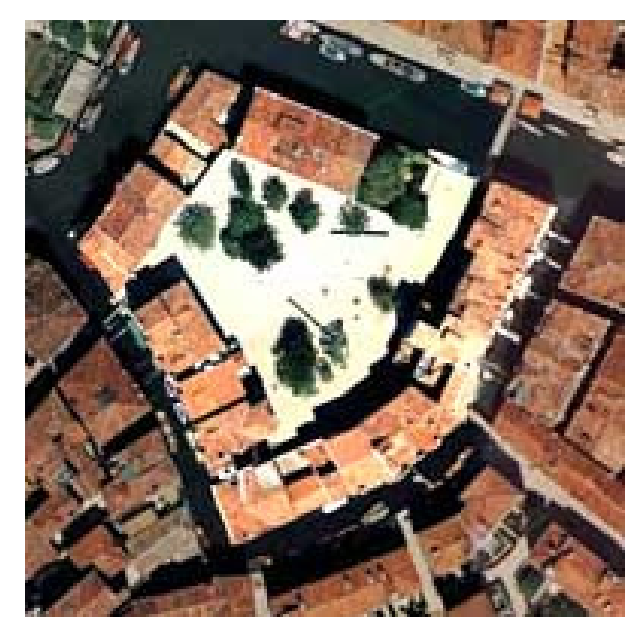

Figura 54: Foto aérea do gueto de Veneza.

Fonte:<http://www.elitehotel.it/pt/the_ancient_jewish_ghetto_in_venice_13pt1341en.htm> Acesso em: 22 dez. 2010. 


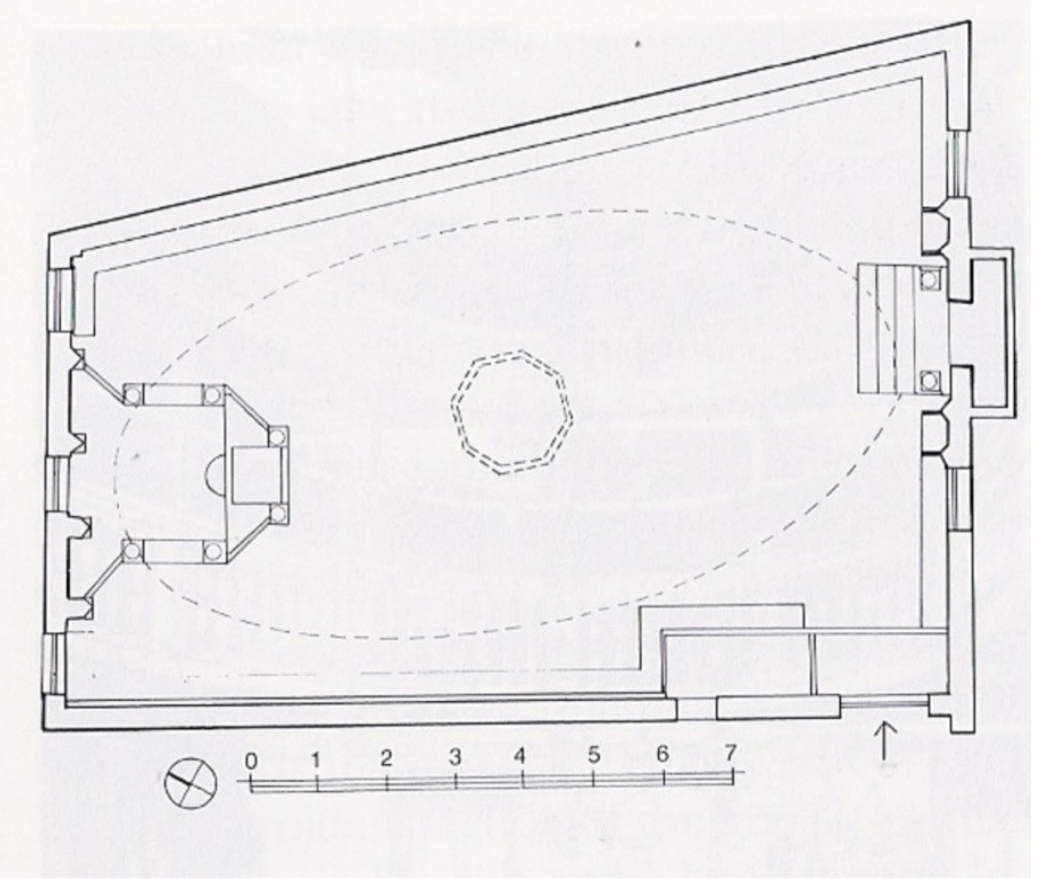

Figura 55: Planta da sinagoga Scuola Tedesca em Veneza, Italia (1528). Fonte: KRINSKY, 1996, p.379.

Os construtores procuravam dar aos edifícios uma aparência exterior discreta, buscando o mínimo de ostentação para que passassem despercebidos, evitando os atos de vandalismo. Gruber $(2004$, p. ) ao tratar das sinagogas desse período, afirma que "nos anos de opressão o exterior era modesto, mas o interior era bastante ornamentado." Levinsky $(2000$, p. ) afirma que:

Nos períodos de intolerância, as sinagogas, buscando não interferir na paisagem ou não se fazer notada em hipótese alguma, por motivos de óbvia proteção, aproveitou-se de andares de residência ou ainda preocupou-se simplesmente com a adequação dos interiores de edifícios já existentes para os fins religiosos, de estudos e encontros sociais. Portanto as sinagogas sempre se preocuparam com seus interiores. 


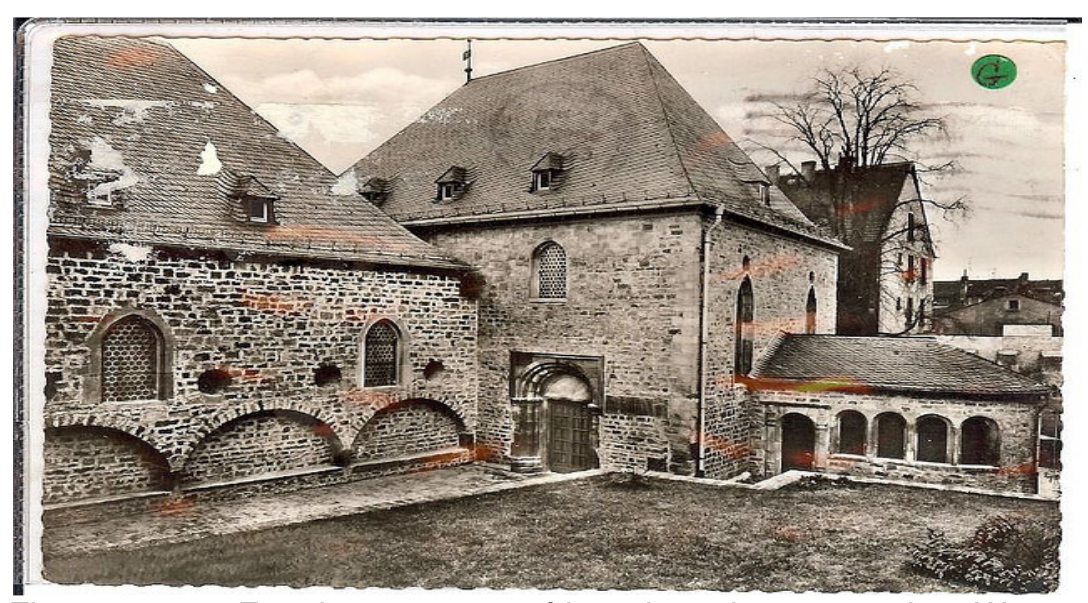

Figura 56: Exterior reconstruído da sinagoga de Worms, Alemanha (1174). Fonte: <http://farm2.static.flickr.com/1242/1118281278_89879fd60f_z.jpg?zz=1> Acesso em: 07 fev. 2011.

Tanto na sinagoga da escuola tedesca de Veneza (fig.57-58) como no edifício da "Santa Maria la Blanca" em Toledo, Espanha (fig.59/53), esse padrão pode ser observado. A sinagoga "Santa Maria la Blanca" em Toledo, na Espanha, é considerada por Krinsky (1996) uma das mais memoriais da Europa, exatamente por causa de seu interior. Entretanto Markman (2003) relata que, ao passar por ela, sua simplicidade exterior pode levar o caminhante a ir adiante sem percebê-la. Sua fachada de tijolos à vista (fig.59) contrasta com seu interior ricamente trabalhado em

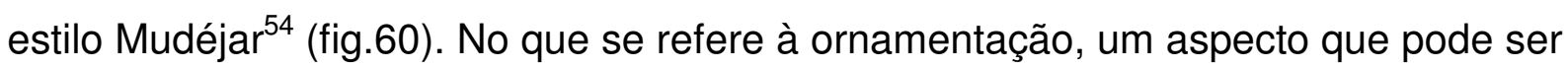
observado é que, quanto à ornamentação utilizada, houve uma negação da arte figurativa. Apesar da rica ornamentação, não é possível encontrar imagens figurativas como no período anterior (fig.52), mas apenas padrões geométricos (fig.58/60).

${ }_{54}$ Mudejár: estilo arquitetônico ibérico, influenciado por elementos mouros. 


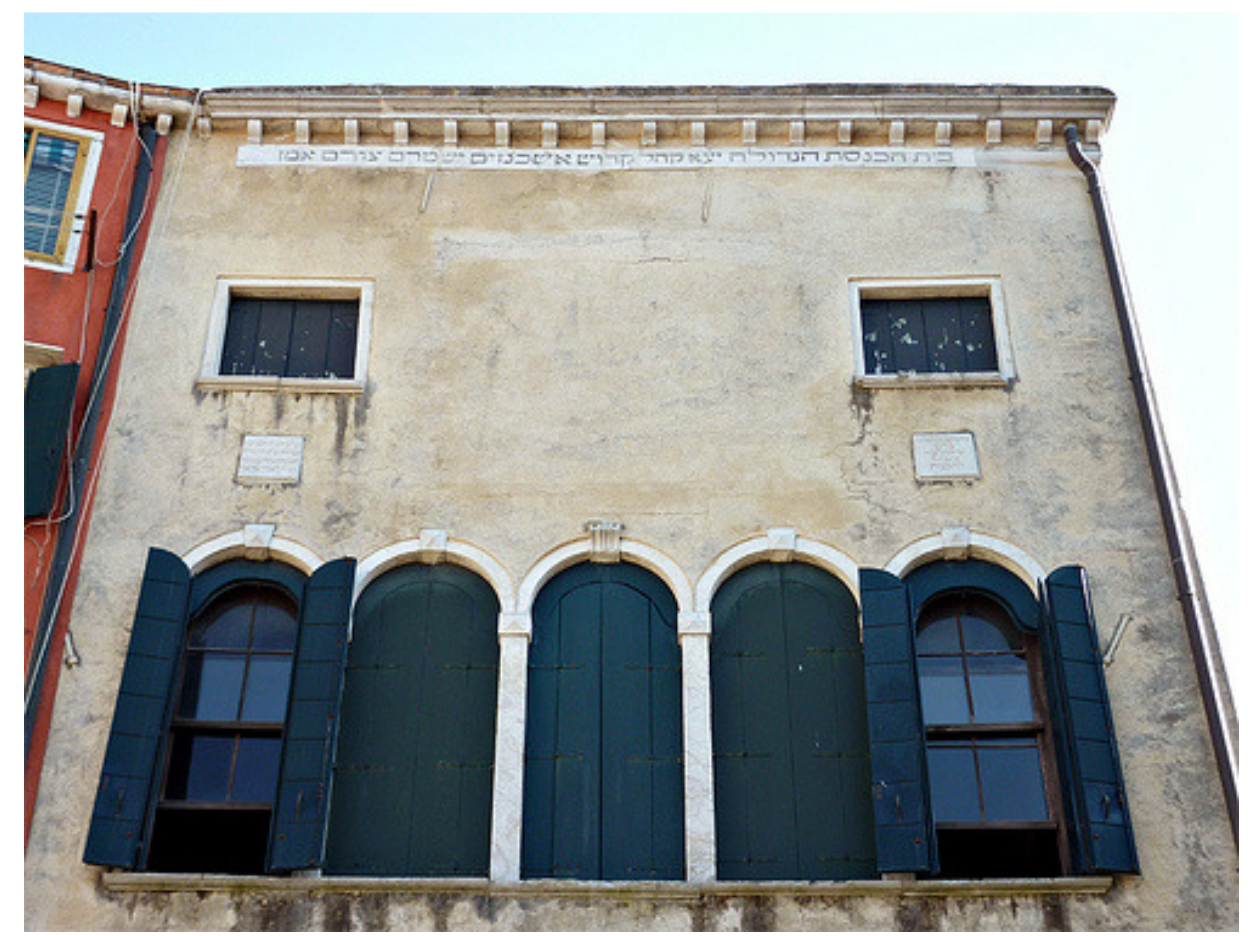

Figura 57: Fachada da sinagoga escuola tedesca de Veneza.

Fonte: <http://www.flickr.com/photos/dkonn/4604847715/> Acesso em: 22 dez. 2010.

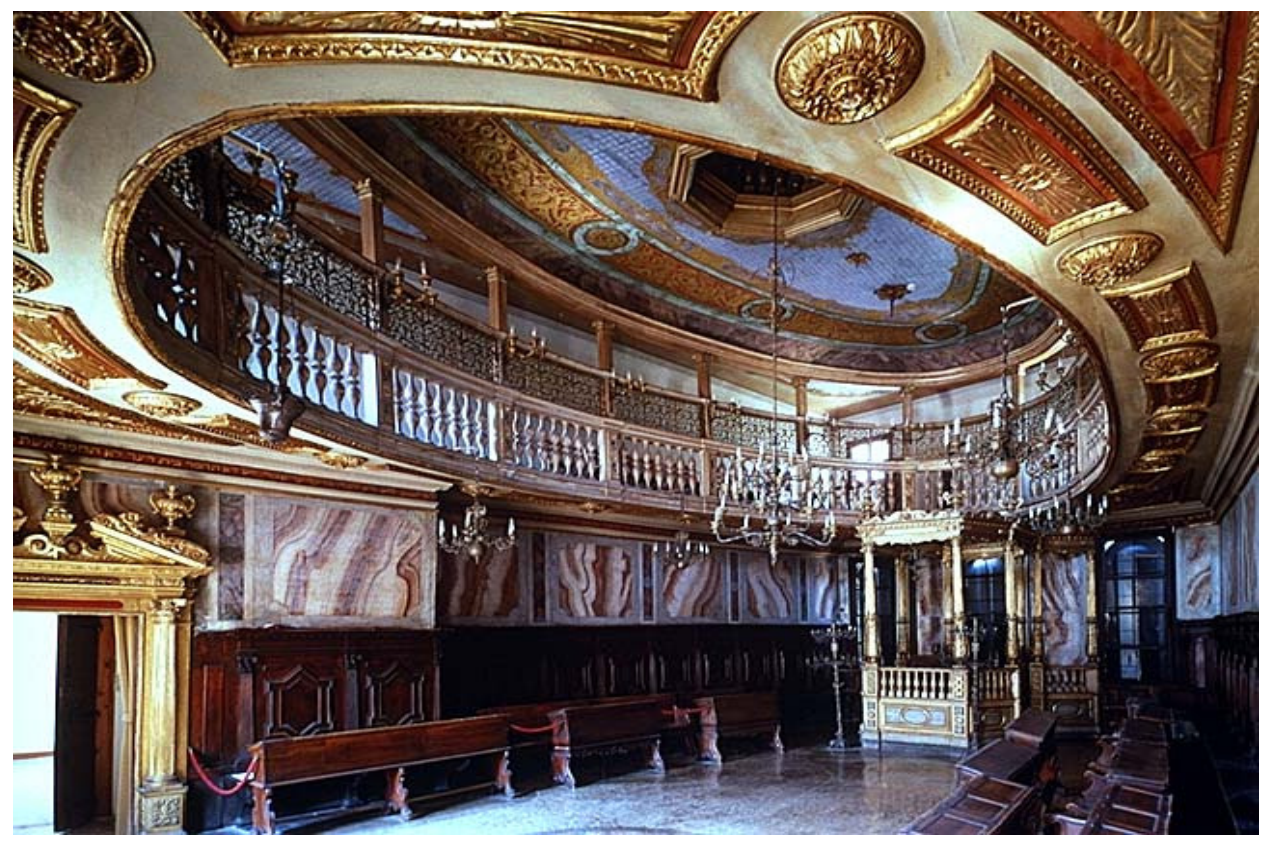

Figura 58: Interior da sinagoga escuola tedesca de Veneza.

Fonte:<http://www.savevenice.org/att/ct/\%7B7689922E-FEAE-4D29-9DD5 777AAA62F12\%7D/Tedesca_intLG.jpg> Acesso em: 24 jan. 2011. 


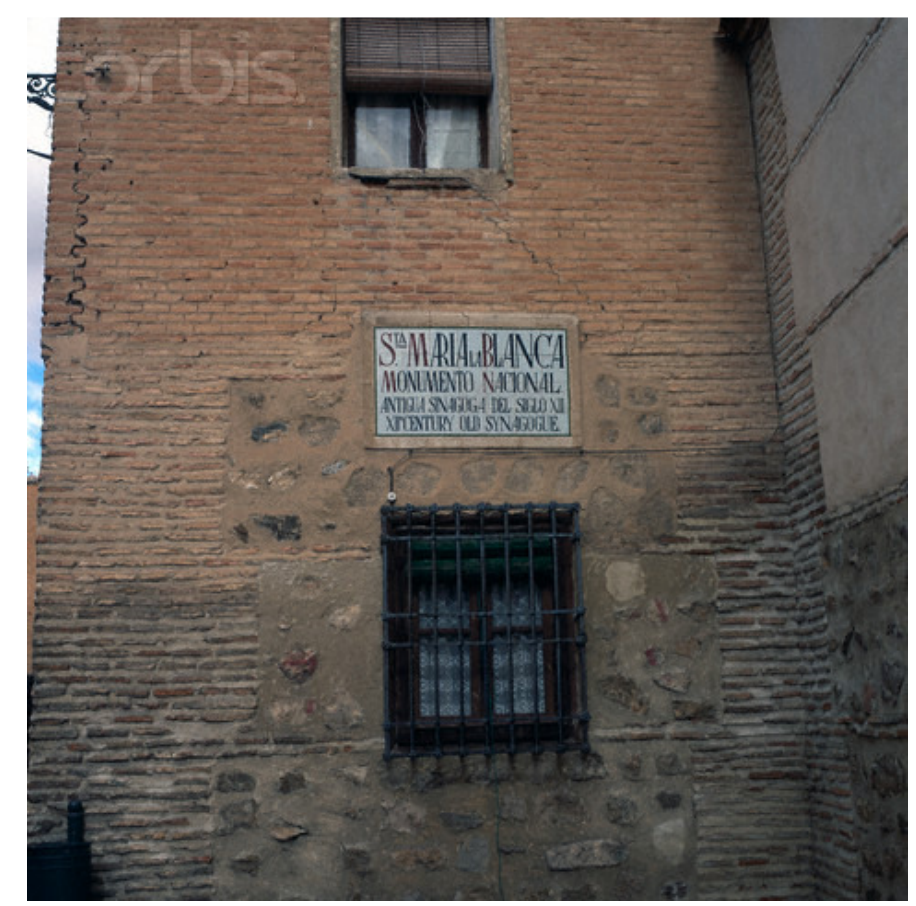

Figura 59: Uma das fachadas da sinagoga "Santa Maria La Blanca" em Toledo, Espanha. Fonte: <http://travel.webshots.com/photo/1391523245073069327QLccrS> Acesso em: 21 dez. 2010.

\subsection{Influência da Localidade}

$\mathrm{Na}$ busca por uma aceitação social, algumas comunidades edificavam suas sinagogas nos estilos arquitetônicos locais. Arquitetos, inseridos em círculos cristãos, projetavam a maioria das sinagogas de forma que a minoria judaica refletiu os desenvolvimentos culturais da sociedade ao seu redor. A partir do século treze, as proporções das sinagogas usaram a escala utilizada nos edifícios de seu tempo. "Santa Maria La Blanca", por exemplo, é formada por um quadrilátero irregular com aproximadamente $26 \times 28 \mathrm{~m}$, composto de quatro linhas de pilares que separam cinco absides paralelos desiguais (fig.61). Essas colunas sustentam vinte e oito arcos em forma de ferradura que alcançam a cobertura com até 12,50 metros de altura (fig.53). As paredes das absides exteriores são lisas, mas as três linhas de pilares interiores são ricamente ornamentadas.

Não é possível afirmar por que a planta de cinco absides foi adotada. Talvez o edifício tenha sido erguido sobre os fundamentos de uma antiga mesquita (KRINSKY, 1996). Apesar desse tipo de planta permitir um edifício mais espaçoso em um lote de comprimento limitado, seus apoios interiores interferem na visibilidade e na acústica. Eles dividem a sinagoga em compartimentos, dissipando uma desejável agregação da congregação. De qualquer maneira a planta demonstra 
a influência da arquitetura local, nesse caso da arquitetura mourisca ${ }^{55}$. O arco em forma de ferradura e os ornamentos também são exemplos dessa influência. Ela pode ter sido adotada para uma adequação ao contexto arquitetônico local, revelando em si a convergência dos fatores culturais e artísticos judeus, cristãos e islâmicos presentes em Toledo naquele momento. Estilos que misturam essas idéias artísticas eram muito comuns na Espanha. Assim como as sinagogas dos períodos anteriores, as desse período também vão adotar os estilos vigentes ao seu redor.

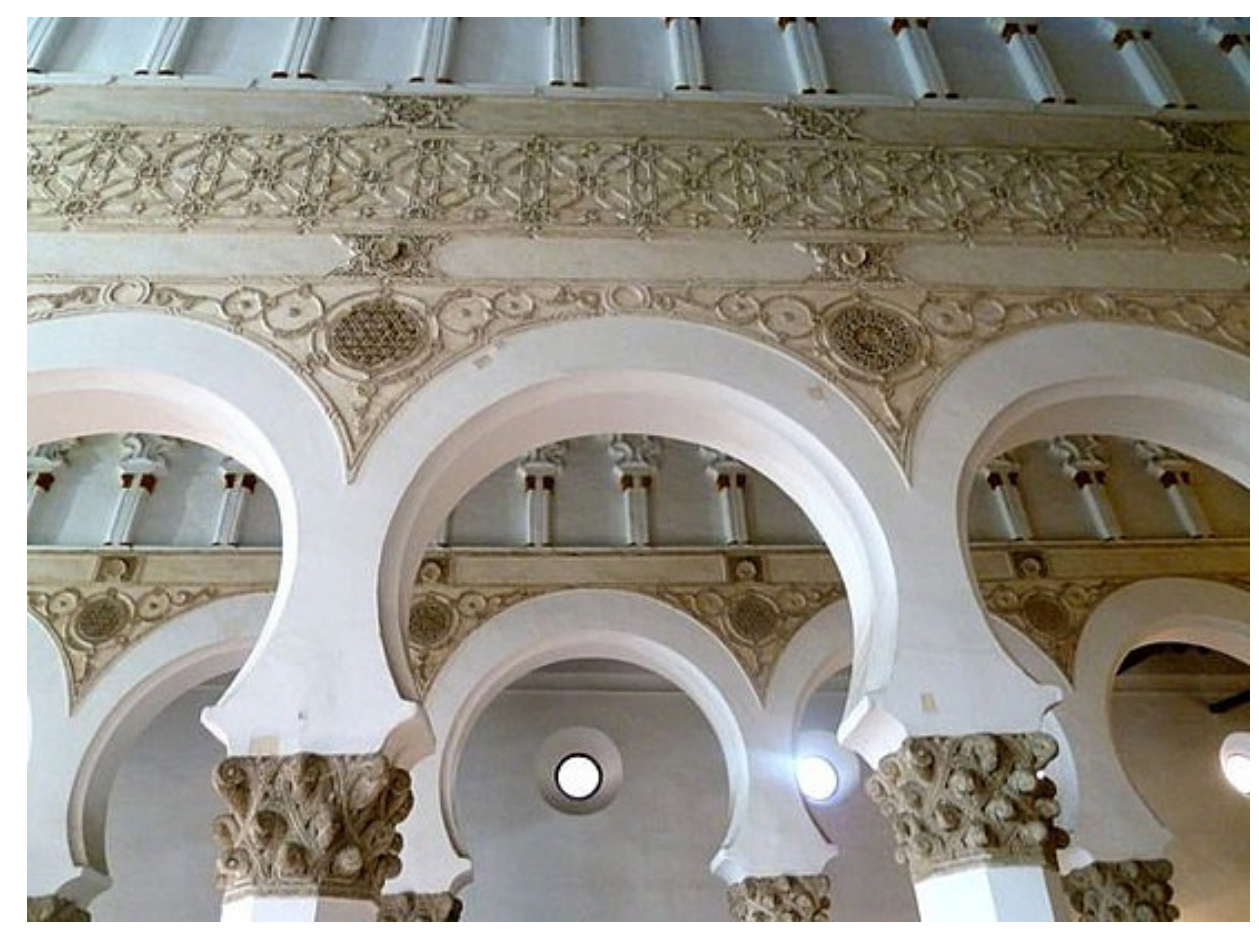

Figura 60: Ornamentos no interior da sinagoga "Santa Maria La Blanca" em Toledo. Fonte:<http://images.travelpod.com/users/slice_n_dice/1.1289599689.1_santa-maria-la-blancasynagoga.jpg> Acesso em: 23 jan. 2011.

${ }_{55} \overline{\text { Mourisco: espanhóis muçulmanos. }}$. 


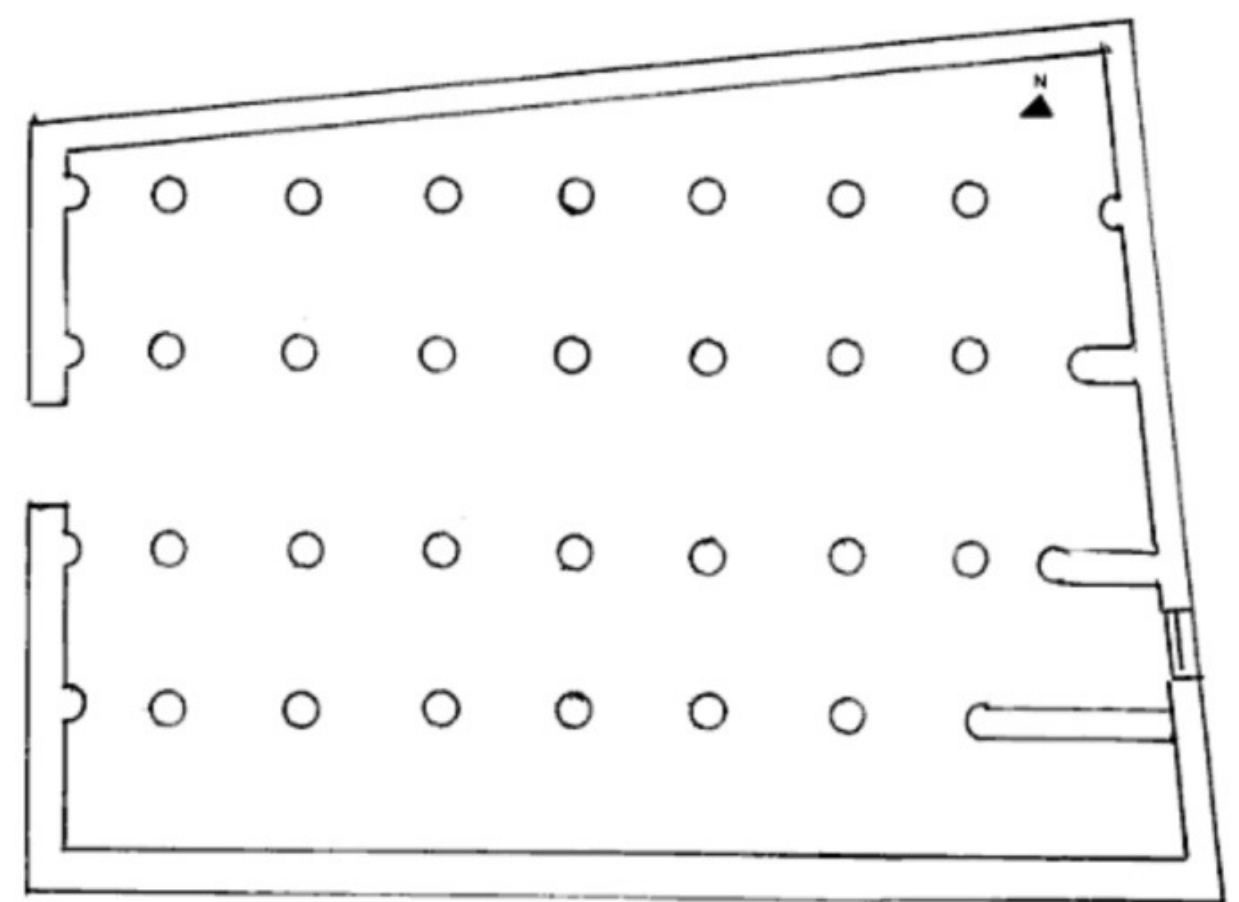

Figura 61: Planta de Santa Maria la Blanca. Fonte: MARKMAN, 2003, p.63.

\subsection{Ordenação Interna}

Devido às adequações pelas quais "Santa Maria la Blanca" passou em 1420 (MARKMAN, 2003), ao ser transformada em uma igreja cristã, não é possível afirmar se havia um nicho para a arca ou como se organizavam a bimah ${ }^{56} \mathrm{e}$ os assentos. Entretanto a maioria das outras sinagogas dessa fase se compõe de corredores divididos por colunas centrais, em cujo eixo se organizavam a arca e a bimah, debaixo de coberturas abobadadas, apoiadas sobre paredes espessas com pequenas janelas ao alto (fig.63). A partir do século XVI, a tendência renascentista de ordenar o espaço hierarquicamente, definindo-os claramente, influenciou a organização interna das sinagogas. Diferentes soluções de plantas surgiram, dependendo da forma como se organizavam a bimah e a arca entre o arranjo das colunas, bem como a área das mulheres e o vestíbulo.

${ }^{56}$ Bimah é a plataforma de onde é feita a leitura da lei, atividade que tem lugar central no serviço da sinagoga. 

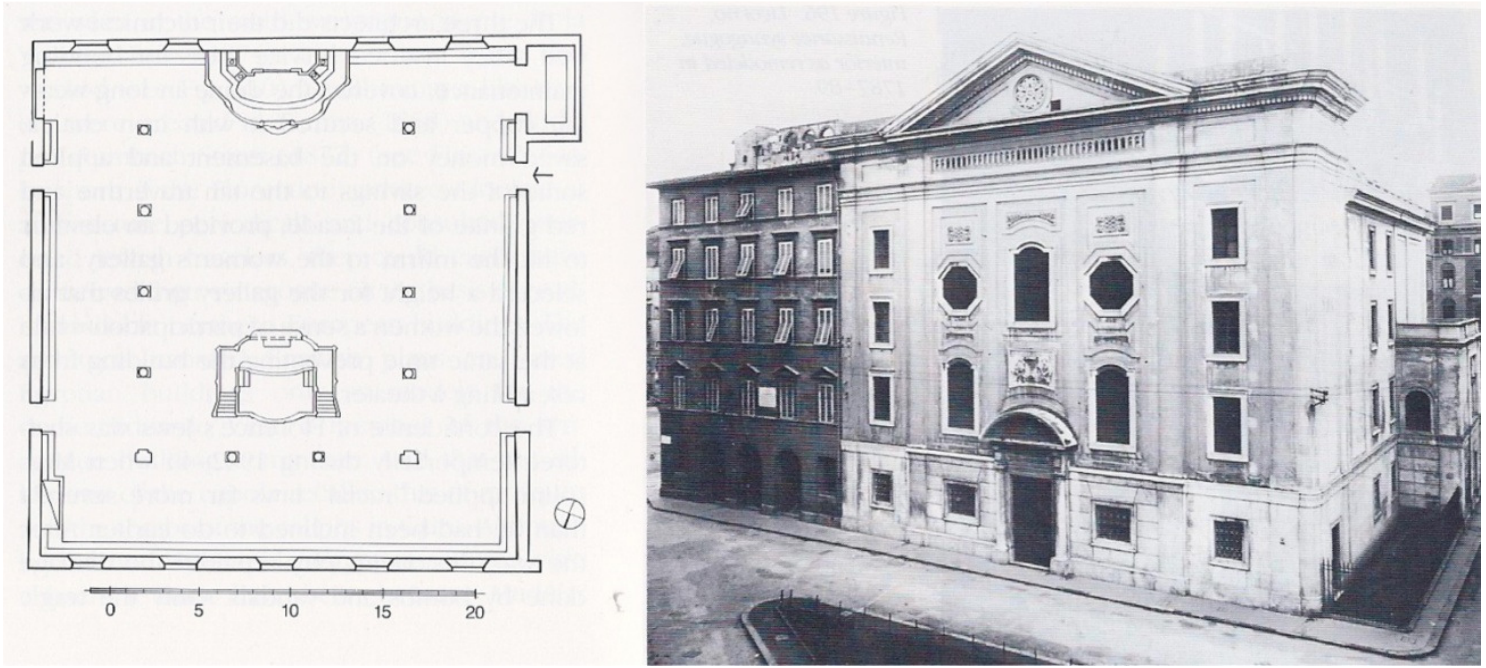

Figura 62: Planta e fachada da sinagoga renascentista de Livorno, Italia (1693). Fonte: KRINSKY, 1996. p.352

Apesar da influência da arquitetura local, essas soluções refletiam principalmente a busca por clarificar as leis judaicas, correspondendo às tendências intelectuais e religiosas da época. Devido à destruição do templo de Jerusalém e ao exílio, as comunidades judaicas tiveram que repensar sua forma de viver a religião. Mestres da lei e pensadores religiosos escreveram uma série de tratados, procurando um novo entendimento sobre as práticas do judaísmo. Com isto, foram escritos uma série de trabalhos legais que governariam aspectos da vida judaica. Eles atualizaram elementos do sistema legal judaico e fizeram leis mais específicas e formais. Os projetistas, por sua vez, tornaram essas leis mais claras nos espaços da sinagoga.

Uma das preocupações era evitar similaridades com a igreja cristã. A bimah junto da arca poderia imitar o altar e o púlpito cristãos. Dessa forma, a bimah deveria localizar-se ao centro ou na parede oposta da arca (fig.55). Maior ênfase também foi dada à oração direcionada à Jerusalém e à parede da arca. Isto levou a uma relação entre a arca e a bimah que desse maior ênfase visual à arca. Degraus foram colocados, antecedendo a arca (fig.63) de forma que os fiéis subissem à Torah a partir "das profundezas", em referência ao livro de Salmos, capítulo 130, do $\operatorname{Tanah}^{57}$.

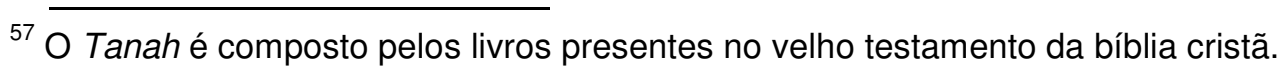




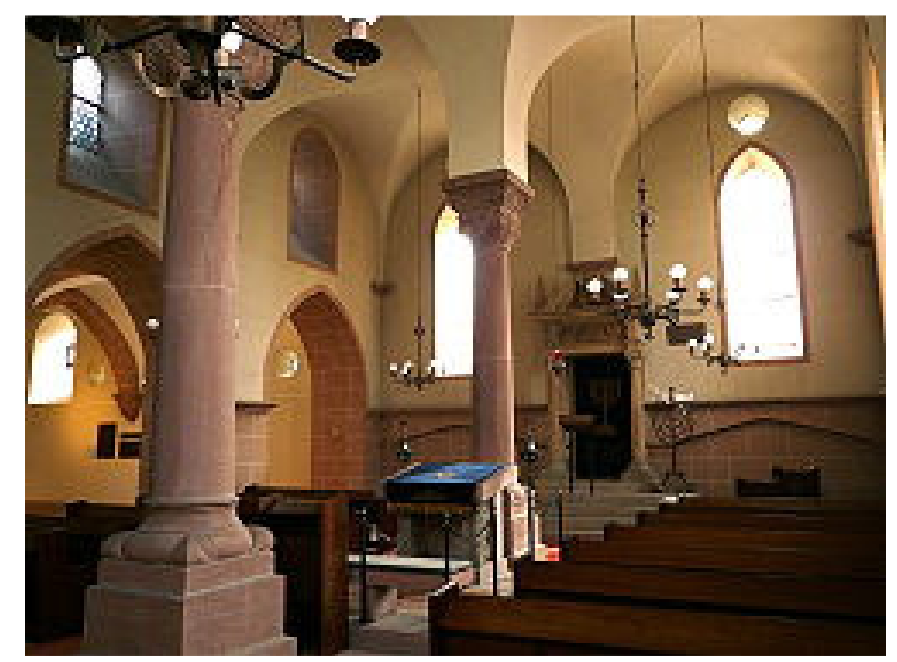

Figura 63: Interior na sinagoga de Worms (1175), com arca sobre degraus ao fundo. Fonte: <http://upload.wikimedia.org/wikipedia/commons/thumb/a/a3/WormsSynagogelnnen.jpg/250pxWormsSynagogelnnen.jpg > Acesso em: 03 dez. 2010.

O vestíbulo também passa a ser disposto mais frequentemente no eixo leste-oeste, como uma preparação para adentrar ao salão, respeitando uma sequência de espaços, como um estágio intermediário onde as atividades mundanas podem ser abandonadas, para então, entrar no salão de orações. Segundo Krinsky (1996), três diferentes organizações de planta vão surgir dependendo do arranjo da arca e da bimah. Nas sinagogas sefaraditas ou de rito italiano, os edifícios são retangulares com a bimah afastada da arca, como na sinagoga em estilo renascentista de Livorno, destruída durante a Segunda Guerra mundial (fig.62).

Nas sinagogas do sul da França e em algumas italianas, os edifícios também são retangulares, mas a bimah fica no extremo oposto da arca, como na já mencionada sinagoga de Veneza (fig.55). No leste europeu, especialmente no séc. XVII, as plantas são quadradas com a bimah centralizada, valorizada pelas colunas centrais. Quatro pilares internos sustentam a abóbada com baías iguais ou oito baías envolvendo uma nona ao centro. Essa configuração era também uma forma de fugir da aparência dos edifícios cristãos com domos ou torres, além de serem mais fáceis de construir. A ênfase na bimah ao centro podia ser feita por meio de uma clarabóia na baía central, ou ligando a cobertura da bimah com a baía central rebaixada, formando um tipo de um Tabernáculo, como na sinagoga de Lancut da Polônia que sobreviveu à destruição (fig.64). 


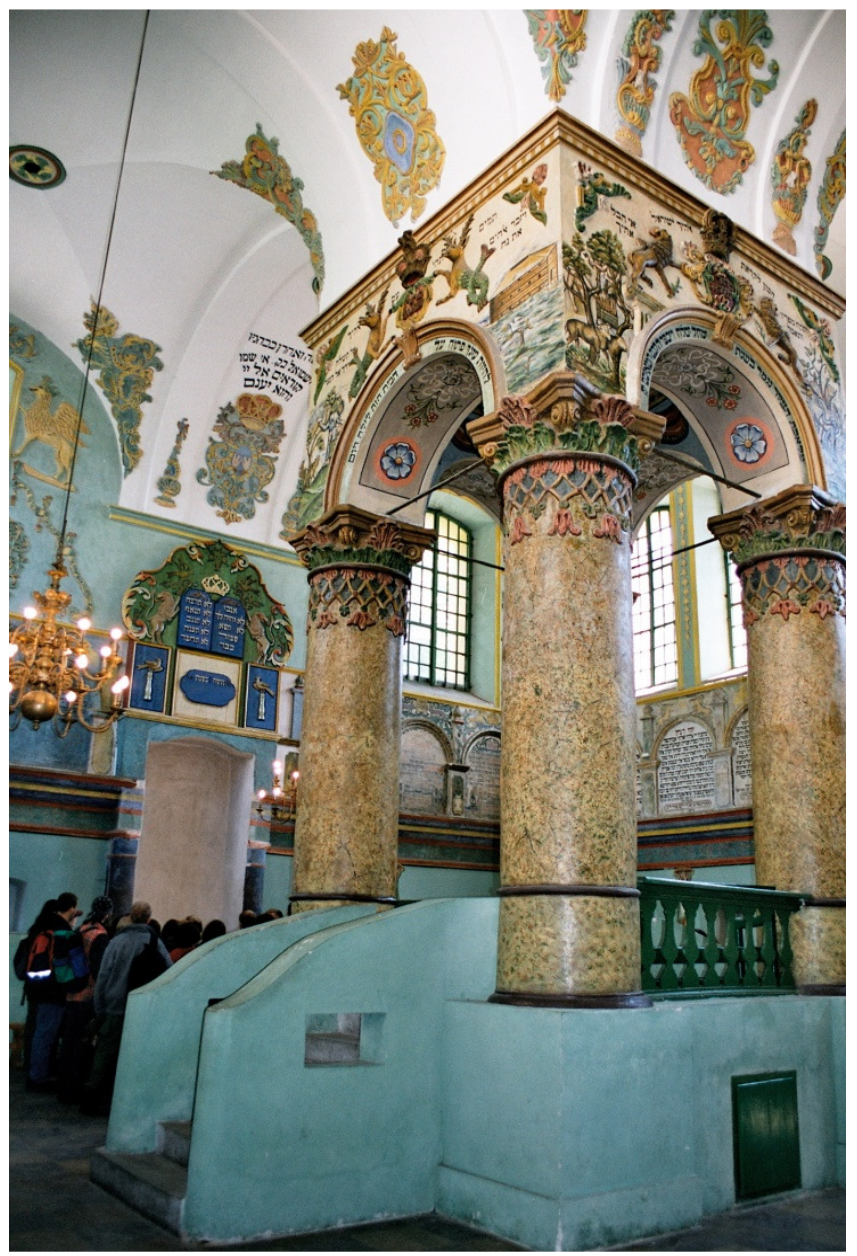

Figura 64: Interior da sinagoga de Lancut.

Fonte:<http://upload.wikimedia.org/wikipedia/commons/9/9a/\%C5\%81a\%C5\%84cut_synagoga06.jpg> Acesso em: 08 fev. 2011.

Nesse período, começaram a surgir também as primeiras soluções para uma separação entre homens e mulheres. Diversas sinagogas se preocuparam com um espaço específico para as mulheres, inicialmente como um anexo ao salão de orações, como na sinagoga de Worms, na Alemanha, construída em 1175. Sua planta (fig.65) é composta por dois pilares dispostos no eixo principal, dividindo o salão de orações em seis abóbadas, com uma pequena abertura na parede para a arca. $O$ anexo das mulheres não podia ser visto a partir do salão dos homens, e seu piso ficava elevado em relação a dos homens, pois suas orações não precisavam vir "das profundezas".

A partir do século XIV, o espaço para as mulheres passou a ser localizado com mais frequência sobre o vestíbulo oeste, oposto à arca. Galerias ao sul e norte, integradas com o salão de orações, também se tornaram muito comuns, como na sinagoga Scuola Grande Tedesca em Veneza, onde a galeria oval se 
destinava às mulheres, que ficavam ocultadas por um gradil (fig. 2.4.5). As galerias serviam não apenas para a separação das mulheres, mas também permitiam que houvesse uma maior ocupação do edifício, uma vez que nos guetos ou quarteirões judaicos não havia espaço para novos edifícios, ou as sinagogas precisavam ser encaixadas em edifícios existentes.

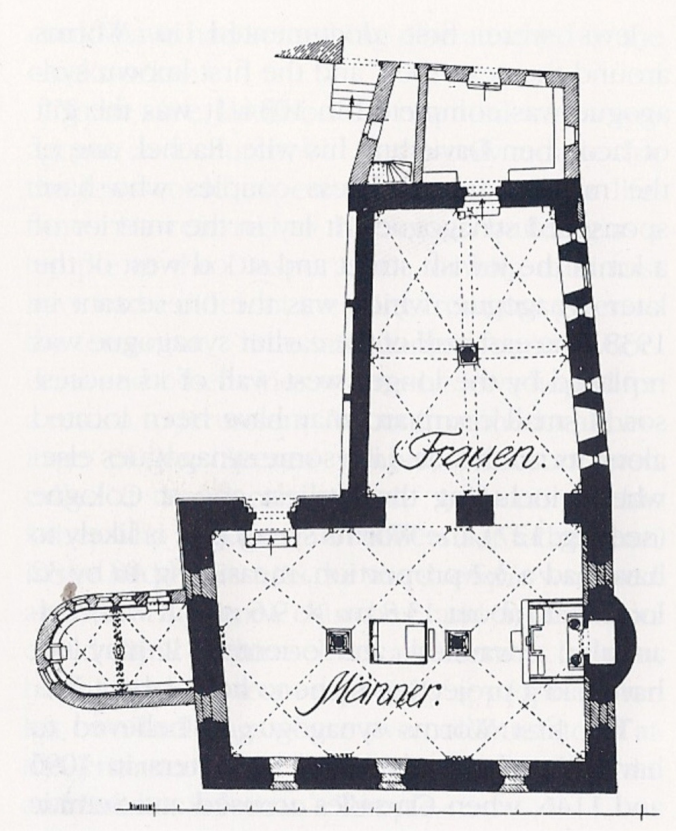

Figura 65: Planta da Sinagoga de Worms, Alemanha. Fonte: KRINSKY. 1996, p.320.

\subsection{Considerações}

A maior parte das sinagogas desse período era composta de edifícios retangulares em pequenas dimensões cujo programa resumia-se principalmente ao salão de orações, devido às condições restritivas sofridas pelas comunidades judaicas.

No que se refere à influência da arquitetura da localidade, esses edifícios construídos durante os séculos de repressão, foram edificados nos estilos vigentes, talvez visando a alguma aceitação pela sociedade cristã ou para talvez de alguma forma não serem identificados como sinagogas, evitando atos de vandalismo.

Sua ordenação interna procurava adequar-se aos princípios da lei judaica, evitando similaridades com a igreja cristã, orientando o edifício para Jerusalém, entre outras determinações. Diversas formulações de planta advieram da ordenação dos elementos da liturgia em meio às colunas de sustentação, dando 
origem a diferentes tipos de planta. Nesse momento começa a surgir a preocupação com a separação entre homens e mulheres, normalmente resolvida por meio de um anexo ou galeria. 


\section{EMANCIPAÇÃO}

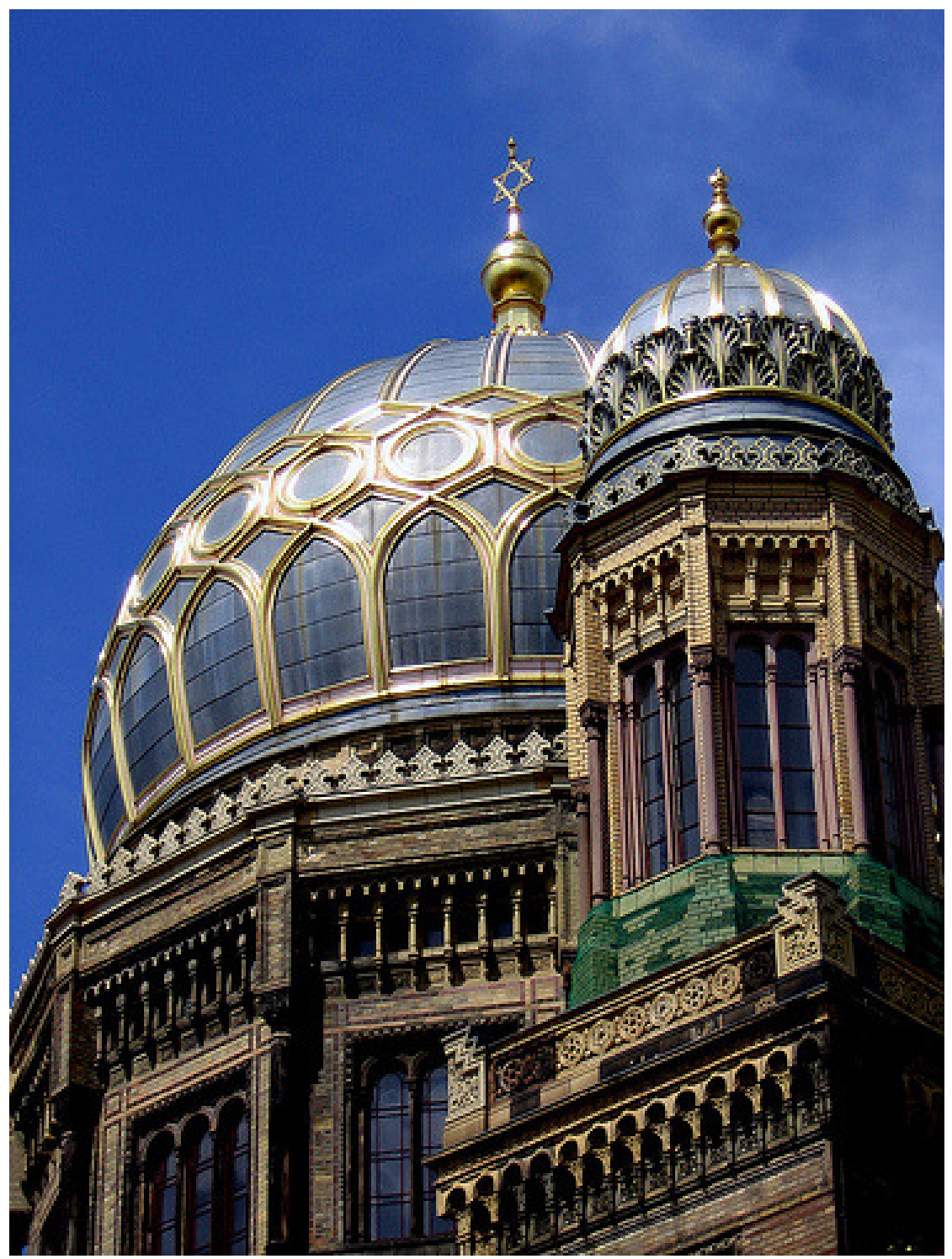

Figura 66: Fachada reconstruída da sinagoga da rua Oranienburg em Berlim (1859). Fonte: <farm1.static.flickr.com/173/376909088_5d24deedcd.jpg> Acesso em: 10 jan. 2011.

\subsection{Contexto Histórico}

O termo "emancipação" refere-se ao processo de concessão de direitos civis aos judeus, em quase toda a Europa, a partir do final do século XVIII. O iluminismo encorajou novas correntes de pensamento que deram aos cristãos uma nova compreensão sobre o judaísmo. Esse momento representou a transição entre uma vida segregada e a convivência com a sociedade em igualdade de direitos, tendo como resultado milhares de sinagogas erguidas. 
Não mais considerados um povo à parte ou sem uma nação, os judeus deveriam agora ser leais a um estado, onde o judaísmo era apenas uma opção religiosa, e Jerusalém, o estado bíblico, devia ser considerado de menor importância (VOOLEN, 2004). Inicia-se aqui um consequente processo de assimilação dos judeus às culturas locais. Nesse contexto se desenvolveu também o movimento reformista, abraçado pelas comunidades judaicas do início do século XIX, que trouxe profundas transformações dentro do judaísmo.

Esse movimento buscava aproximar o judaísmo das condições modernas, eliminando tradições litúrgicas que não tinham mais aplicação naquele momento. Eles permitiram a introdução de mudanças radicais como a abolição das regras da Kasherut $t^{58}$, a relativização da observância do $S h a b a t^{59}$ e do movimento sionista $^{60}$. Segundo Ekerman (2007), o reformismo representou uma importante mudança, a primeira tentativa de materializar a assimilação judaica em seu novo espaço de culto, além de tornar possível ao judaísmo congregar grandes comunidades urbanas. É nesse contexto que também surge na Europa o movimento moderno, no qual as comunidades reformistas encontraram um meio para expressar suas novas aspirações. Esse período se inicia nesse contexto e termina com a ascensão do nazismo na Alemanha nos anos 1930.

Para demonstrar as transformações desse período foram escolhidas sinagogas das seguintes localidades: Berlin, Alemanha - 1859, Budapest, Hungria 1866, Varsóvia, Polônia - 1874, Florença, Itália - 1882, Plauen, Alemanha - 1930 e Zilina, Eslováquia - 1928.

\subsection{Programa de Necessidades}

A nova posição social dos judeus permitiu mudanças significativas na arquitetura das sinagogas. Os edifícios, que antes não passavam de pequenos e discretos locais de reunião, assumiram novas escalas, marcadas por construções monumentais abertas para a rua, inclusive em vias importantes e praças. Como

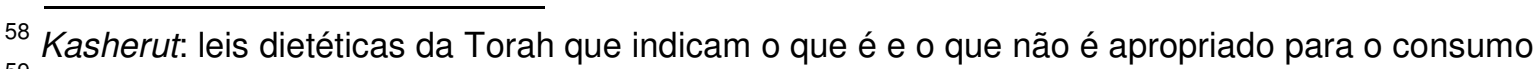

${ }^{59}$ O Shabat corresponde ao sábado ocidental, o sétimo dia da criação, quando, por ordenação divina, nenhum tipo de trabalho deve ser realizado.

${ }^{60}$ Sionismo é um movimento surgido no século XIX que defendia a criação de um estado judaico na Palestina e o retorno de todos os judeus a este estado.
} 
poderiam viver onde quisessem, muitos judeus deixaram os vilarejos e o campo pelas cidades, o que aumentou muito o número pessoas nas comunidades.

Procurando confirmar seu lugar na sociedade e evitar que os jovens fossem seduzidos pelas vantagens sociais dos cristãos, a sinagoga deixou seu aspecto intimista e começou a abrigar, em grandes edifícios, congregações de milhares de pessoas, onde a comunidade se sentisse merecedora de seu novo status civil. Proponentes dos novos edifícios achavam as sinagogas pequenas socialmente insatisfatórias. Pessoas indiferentes deixavam sua membresia ou evitavam contribuições para congregações não atraentes. Krinsky (1996, p.265 trad. nossa), ao comentar sobre a sinagoga de Berlim (fig.66), afirma que:

\footnotetext{
foi uma das primeiras sinagogas a ter uma cúpula exterior ressaltada, e o fato de a cúpula ser bolbosa e dourada mostra que os líderes da judiaria de Berlim queriam que seu edifício tivesse um forte impacto na paisagem da cidade, como para proclamar seus novos direitos alcançados.
}

Essa mudança garantia que as sinagogas oferecessem um espaço onde toda a família pudesse gozar de um ambiente confortável e bem planejado, além de oferecer um maior atrativo aos jovens, constantemente tentados a converterem-se ao cristianismo. Novos espaços foram acrescentados aos edifícios, como salas de espera e salas de vestir para noivas, hall ou edifício social, salas de vestir e escritórios para o rabino ou o chazan e até varandas para oferecer proteção a quem chegasse de carruagem durante a chuva (fig.74). Essas mudanças sugerem também que a sinagoga começou a ser utilizada como um lugar para atividades de caráter políticos e sociais (KRINSKY, 1996).

Dessa forma, pode-se concluir que as sinagogas, surgidas durante a emancipação dos judeus, tinham grandes dimensões, visando demonstrar as novas condições civis alcançadas pelos judeus.

\subsection{Influência da Localidade}

Durante esse período, as sinagogas foram construídas em diversos estilos diferentes. A Europa desse momento era marcada por uma arquitetura eclética de referência historicista (EKERMAN, 2007). A oportunidade de integração com a sociedade cristã levou as comunidades judaicas a adotar estilos que os 
identificassem com o restante da sociedade (KRINNKY, 1996) e expressassem o pertencimento a seu próprio país. Isto se deu também pela ausência de um poder centralizado dentro do judaísmo e pelos diversos tipos de rito, somados à flexibilidade de um grupo habituado a responder prontamente às pressões externas.

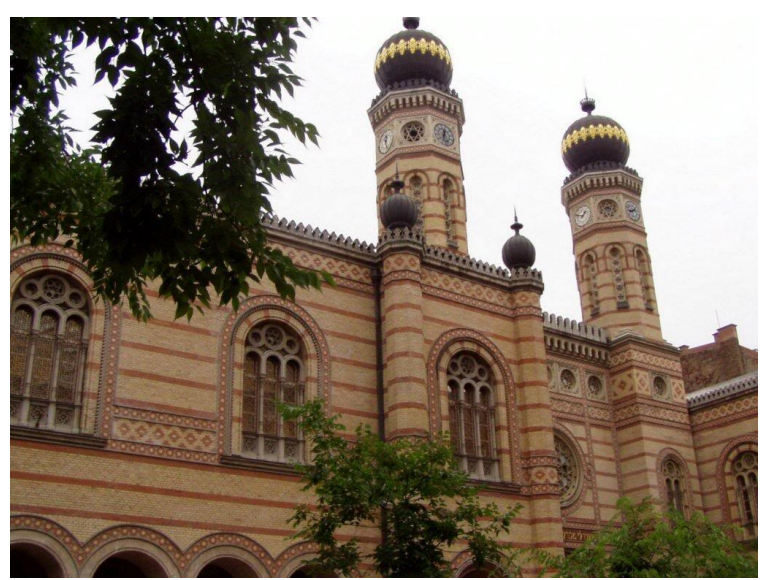

Figura 67: Fachada e interior da sinagoga de Budapest.

Fonte: <image59.webshots.com/59/2/91/98/2529291980010442789wMpZal_fs.jpg> Acesso em: 03 jan. 2011.

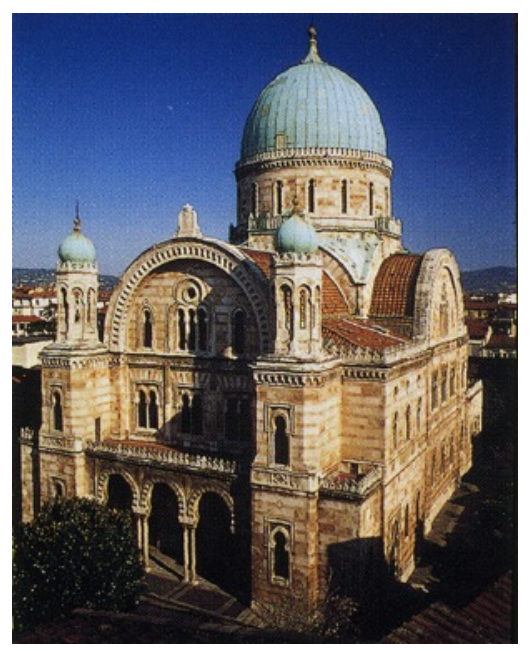

Figura 68: Fachada da sinagoga de Florença. Fonte: <http://richardmcbee.com/words/florence.jpg> Acesso em: 03 jan. 2011.

Nesse momento, começaram a surgir as primeiras tentativas no sentido de se encontrar uma linguagem própria na arquitetura (VOOLEN, 2004). Livres para expressar sua crença e preocupados em incorporar sua identidade nos edifícios, os judeus começaram a aplicar elementos de identificação nas fachadas, 
como a estrela de Davi (fig.66), os "Dez Mandamentos" (fig.69) ou a menorah (fig.70), o candelabro de sete braços que fazia parte dos utensílios sagrados do Templo de Jerusalém. Algumas sinagogas optaram por reviver o clássico (fig.70), ligando seu design com achados arqueológicos na palestina (KRINSKY, 1996).

Outra tentativa de incorporar uma identidade aos edifícios foi a utilização do estilo mourisco, mais comum a partir do final do final do séc. XIX, quando museus e exibições sobre a religião e cultura judaica, frequentados por uma burguesia judaica secularizada, mostravam glórias passadas das épocas áureas dos judeus da Espanha e Portugal ${ }^{62}$. O estilo foi amplamente utilizado, pois destacava a origem oriental dos judeus e ressaltava um sentimento nostálgico e romântico, por meio de elementos que relembrassem como se imaginava que essa origem fosse.

Um exemplo foi a sinagoga de Budapest (fig.67), cujo projeto foi escolhido, pois trazia uma proposta em estilo mourisco, em que se acreditava apresentar um "puro estilo oriental", nos quais os elementos do Templo de Jerusalém estavam unidos com sucesso. Seu estilo e tamanho se aproximavam do Templo, e as torres estavam relacionadas às colunas Joaquim e Boaz ${ }^{63}$ utilizadas no Templo. Os projetistas desse tempo dificilmente poderiam fazer mais que estas referências superficiais, pois as descrições antigas do Templo não eram claras, e as ilustrações acadêmicas ofereciam uma quase desnorteada variedade de reconstruções não similares entre si (KRINSKY, 1996).

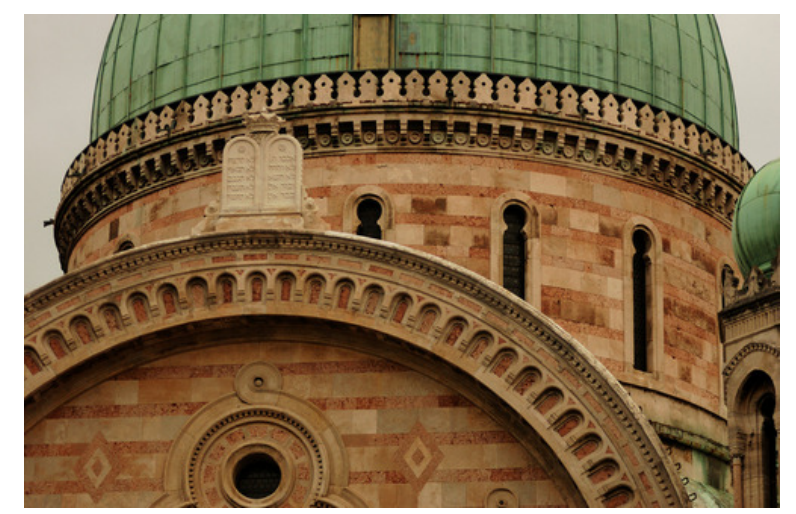

Figura 69: Aplicação dos Dez Mandamentos na fachada da sinagoga de Florença. Fonte: <http://www.planetware.com/i/photo/synagogue-florence-ir1377.jpg> Acesso em: 03 jan. 2011.

${ }^{61}$ Os "Dez Mandamentos" referem-se às leis escritas por Deus em tábuas de pedra e entregues à Moisés para mais tarde ser guardada dentro da arca da aliança, móvel que permanecia no ambiente chamado de Santo dos Santos no Tabernáculo ou no Templo.

${ }^{62}$ Espanha e Portugal tiveram um período de grande prosperidade sob domínio muçulmano, quando as comunidades judaicas gozavam de boas relações com o estado.

${ }^{63}$ Colunas presente no primeiro Templo de Jerusalém, edificado por Salomão por volta do séc. X a.C. 


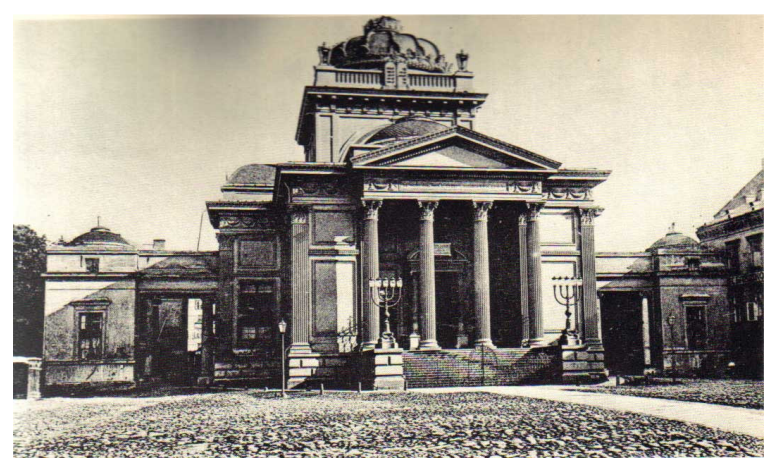

Figura 70: Fachada da sinagoga de Varsóvia com a aplicação da menorah.

Fonte: <http://www.thejmca.com/TlomatskAlpha.jpg> Acesso em: 03 jan. 2011.

Entre o fim da primeira guerra e a ascensão do nazismo em 1933, várias sinagogas foram construídas em estilo moderno, das quais muitas acabaram destruídas na Segunda Guerra Mundial. No período entre guerras, judeus de muitas regiões da Europa abraçaram aspectos progressistas do design. Ávidos por serem assimilados na sociedade, viam a si mesmos como intelectuais progressistas que procuravam expressar sua atitude com novos estilos arquitetônicos. As novas formas da arquitetura moderna foram facilmente adaptadas ao design das sinagogas (GRUBER, 2004).

O Estilo Internacional ${ }^{64}$ pregava 0 abandono das referências historicistas e a eliminação do ornamento. O problema da decoração na sinagoga se tornou especialmente acurado nos anos 1930, quando as teorias da arte modernista começaram a afetar o design das sinagogas. Congregações ortodoxas também construíram em estilos comparáveis, pois não viam contradição entre sua fé tradicional e as novas formas que proviam poucas distrações das orações. A ausência de ornamento e as formas puras foram facilmente adaptadas ao caráter iconoclasta do culto judaico. Assim, retirou-se da decoração e das referências do ecletismo neo-historicista a responsabilidade pela procura de uma identidade judaica dentro da sinagoga. O movimento reformista viu na nova arquitetura a oportunidade de consolidar seus paradigmas de renovação.

\footnotetext{
A essência da linguagem modernista, atenta ao espaço tridimensional e às funções nele desempenhadas, modificou a sinagoga não através da importação de modelos tipológicos e decorativos, mas ressaltando o cenário para a liturgia existente através da manipulação da estrutura, dos materiais e das aberturas, dentre outros (EKERMAN, 2007, p. 49).
}

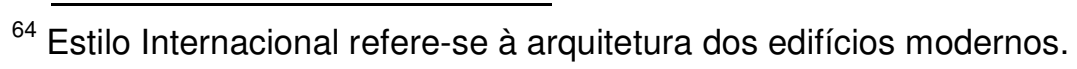


Um exemplo da eliminação do ornamento é a sinagoga de Zilina, na Eslováquia (fig.71). Construída em 1928, ela é considerada uma versão despida da sinagoga em estilo bizantino. Apesar de projetada por Peter Behrens, arquiteto que influenciou Le Corbusier, Mies e Gropius, a sinagoga de Zilina tem pouco em comum com o Estilo Internacional. Sua ênfase está na simplicidade geométrica de sua forma e no uso do concreto armado para produzi-la.

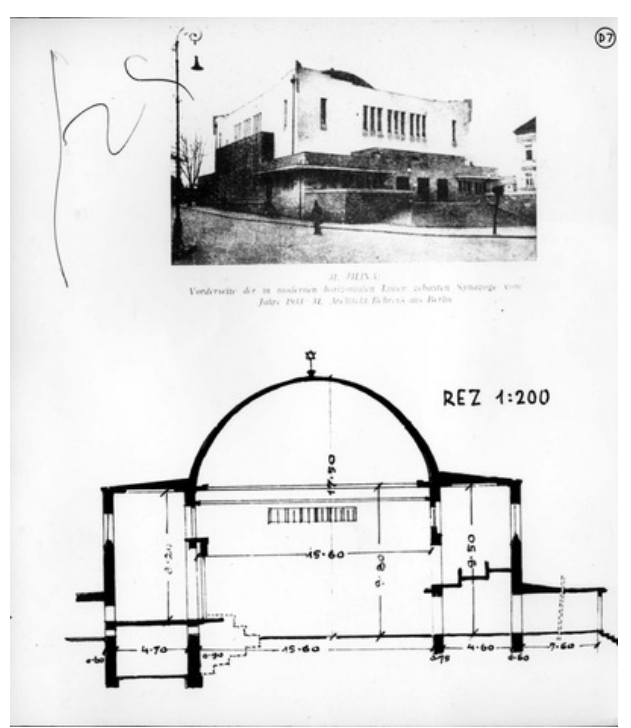

Figura 71: Fachada e corte da sinagoga de Zilina.

Fonte:<ttp://collections.yadvashem.org/photosarchive/s637-469/11694356157076661996.jpg> Acesso em 11 jan. 2011.

Já o edifício construído pela comunidade de Plauen, na Alemanha (fig.72-73), é considerado a sinagoga que mais absorveu os elementos do recém surgido movimento moderno (Krinsky, 1996). Construída em 1930, seu edifício é composto de uma simples caixa retangular, com estrutura em aço e paredes finas. Ela claramente alcançou diferentes efeitos principalmente na manipulação dos elementos arquitetônicos, mais que adicionando detalhes orientais. $\mathrm{O}$ arquiteto Fritz Landauer intensificou a verticalidade do interior, abaixando as galerias e erguendo as janelas do clerestório ${ }^{65}$ para exagerar a distância entre eles e assim fazer com que o salão parecesse muito mais alto do que efetivamente era. Ele ajustou os efeitos de luz, iluminando os assentos e criando uma penumbra próxima à cobertura escura, e focou a atenção da congregação ao ministro ao elevar a arca e a bimah, inclinando o piso levemente para permitir que os fiéis pudessem ver claramente.

${ }^{65}$ Clerestório: seção superior da parede com aberturas laterais nas igrejas góticas. 
Krinsky (1996) afirma que alinhar as sinagogas com o novo estilo internacional permitia que as comunidades andassem em dia com a cultura local, na qual os judeus esperavam ser confortavelmente estabelecidos.

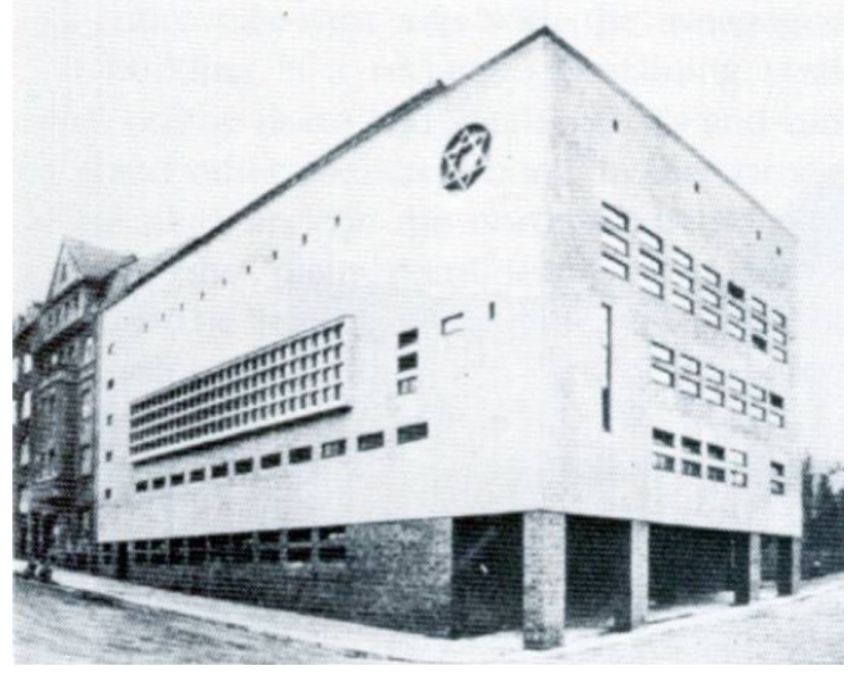

Figura 72: Fachada da sinagoga de Plauen, Alemanha.Fonte: KRINSKY, 1996, p.305.

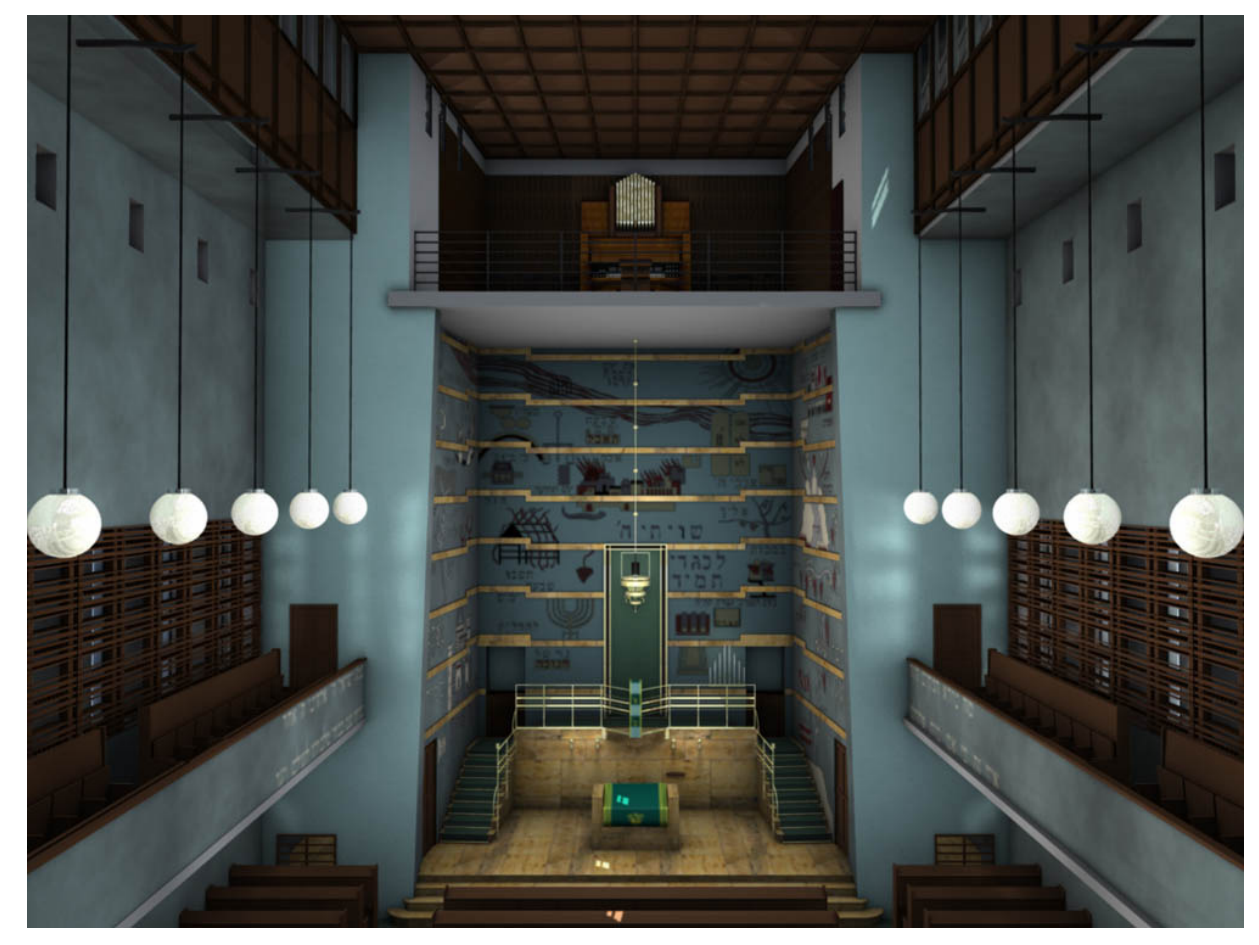

Figura 73: Interior da sinagoa de Plauen. Fonte:<http://www.tudarmstadt.de/vorbeischauen/aktuell/nachrichten_1/synagogenexhibition.en.jsp?aktuelles_bild=15\&gal erie $=2904383 \#$ bildergalerie $>$ Acesso em: 05 jan. 2011.

\subsection{Ordenação Interna}


Por conta das mudanças implementadas pelo movimento reformista, as referências ao Templo, durante a liturgia, foram esquecidas (VOOLEN, 2004). Um novo arranjo foi adotado na organização da arca e da bimah ${ }^{66}$, assumindo ambas o foco principal ao leste, dispondo a congregação em forma de auditório com uma configuração mais similar à das igrejas cristãs (fig.74-76). Krinsky (1996) afirma que muitas dessas mudanças foram motivadas por características das igrejas protestantes, cuja ênfase estava sobre a pregação, que abordava especialmente aspectos de comportamento no lugar de dogmas ou rituais. As congregações se assentavam em salões que eram essencialmente locais de palestras e encontro para se ouvir a um ministro. Os projetistas das igrejas protestantes trabalhavam para que todas as partes do edifício fossem visíveis e se certificavam de que o ministro pudesse ser ouvido por meio deste.

Com a emancipação, os rabinos assumiram uma configuração mais parecida com os sacerdotes cristãos, não mais uma autoridade aprovada pelos membros da comunidade, mas graduado em um seminário teológico. Nessa mesma linha, os reformistas começaram a ver 0 rabino e o chazan ${ }^{67}$ como líderes de orações coletivas organizadas, que deveriam ser recitadas por uma voz ou por toda a congregação em uníssono ao invés de por cada indivíduo em seu próprio compasso. Isto deveria acontecer em edifícios sem barreiras visuais e onde não poderia haver comportamentos informais. Todos deveriam se sentar tranquilamente, direcionados para o leste, onde a bimah, agora movida do centro para junto da arca, teve sua cobertura removida e substituída por uma simples mesa.

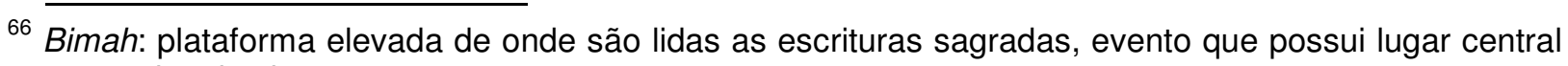
no serviço da sinagoga.

${ }^{67}$ Chazan: literalmente "cantor", é o personagem da liturgia que guia a congregação nas orações e recita determinadas bênçãos durante os serviços. 


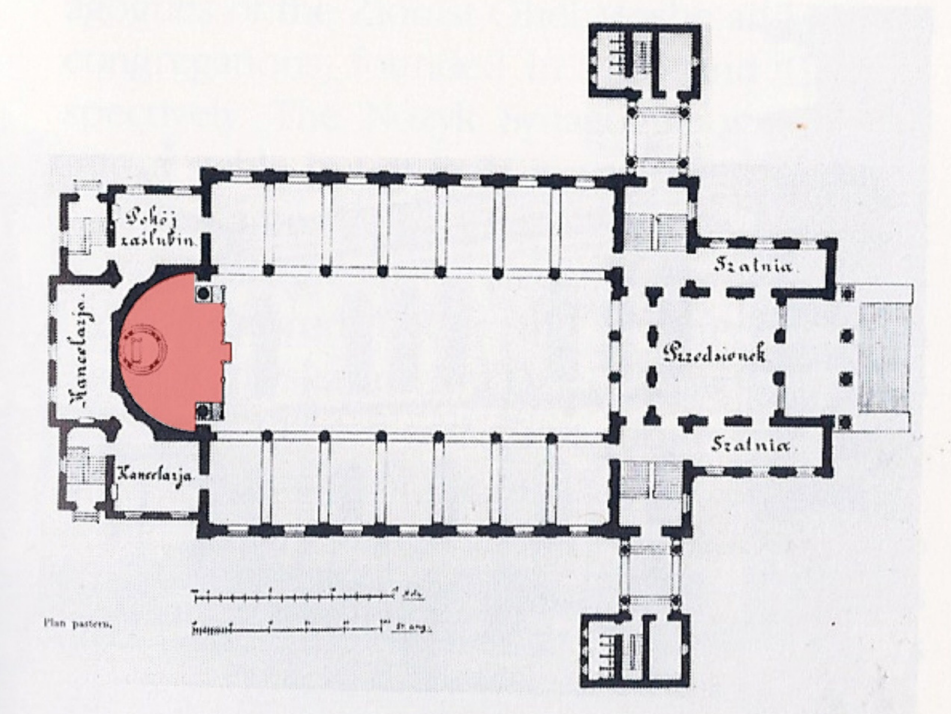

Figura 74: Plantas da sinagoga de Warsaw. Fonte: KRINSKY, 1996, p.233.

O espaço para as mulheres também passou por transformações. As grades de separação foram rebaixadas ou até mesmo extintas. As paredes foram rasgadas com grandes aberturas ou totalmente eliminadas. Ávidos por promover atividades que unissem a família judaica, os reformadores permitiram que as mulheres pudessem ver e ouvir os serviços facilmente e também permitiram aos homens ver as mulheres durante as orações, apesar de ainda manter a separação entre os sexos. Os serviços reformistas eram conduzidos na língua local para que as mulheres pudessem ler e acompanhar as leituras, por isso o salão das mulheres também deveria ter boa iluminação, além de provido de toaletes e salas de repouso (fig.75). 

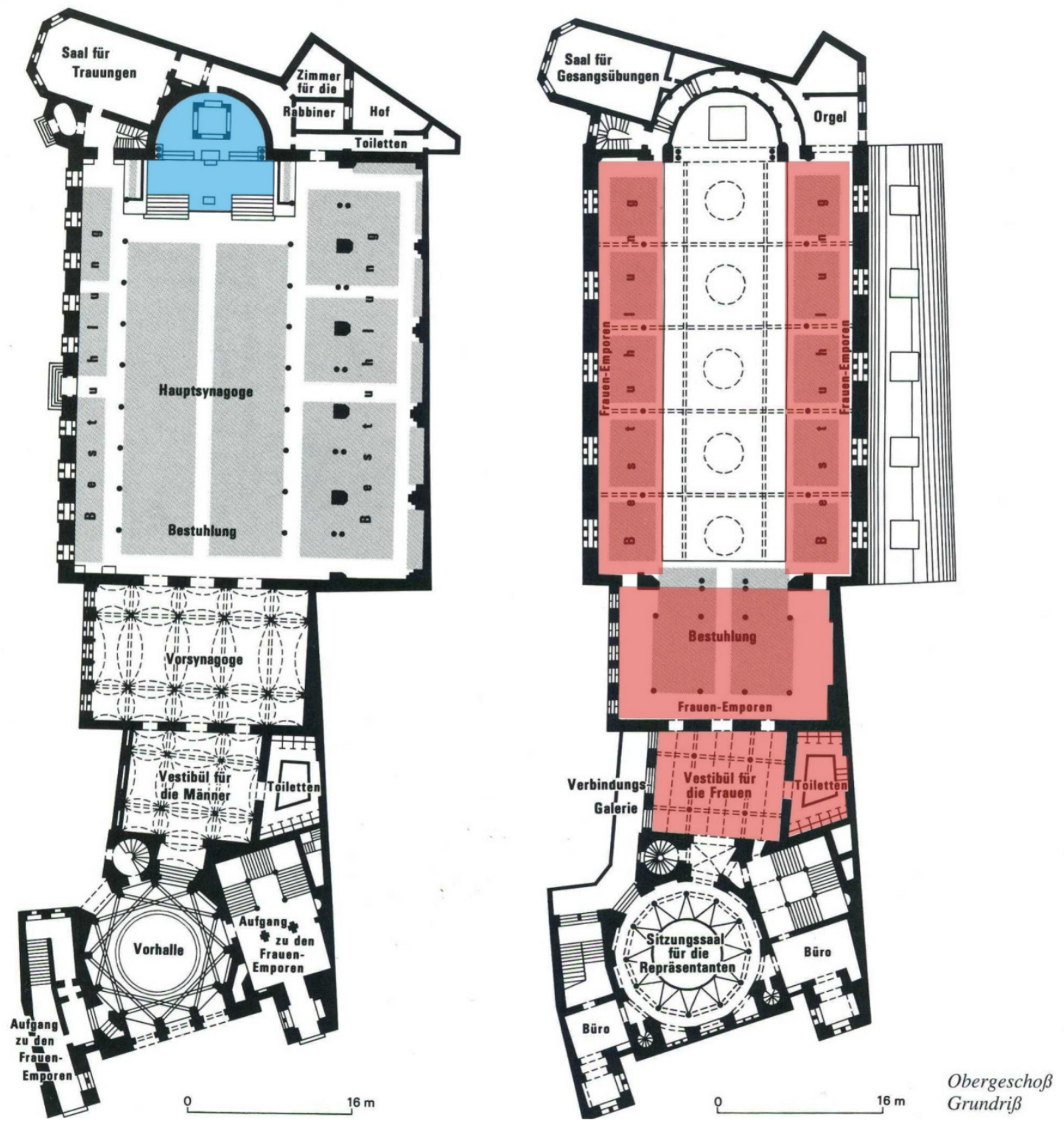

Figura 75: Plantas da sinagoga de Berlin. Destaque para bimah junto à arca e instalações voltadas às mulheres (edição do autor).

Fonte:<upload.wikimedia.org/wikipedia/commons/6/61/Berlin_Synagoge_Oranienburgerstrasse_Grun driss.jpg > Acesso em: 03 jan. 2011. 


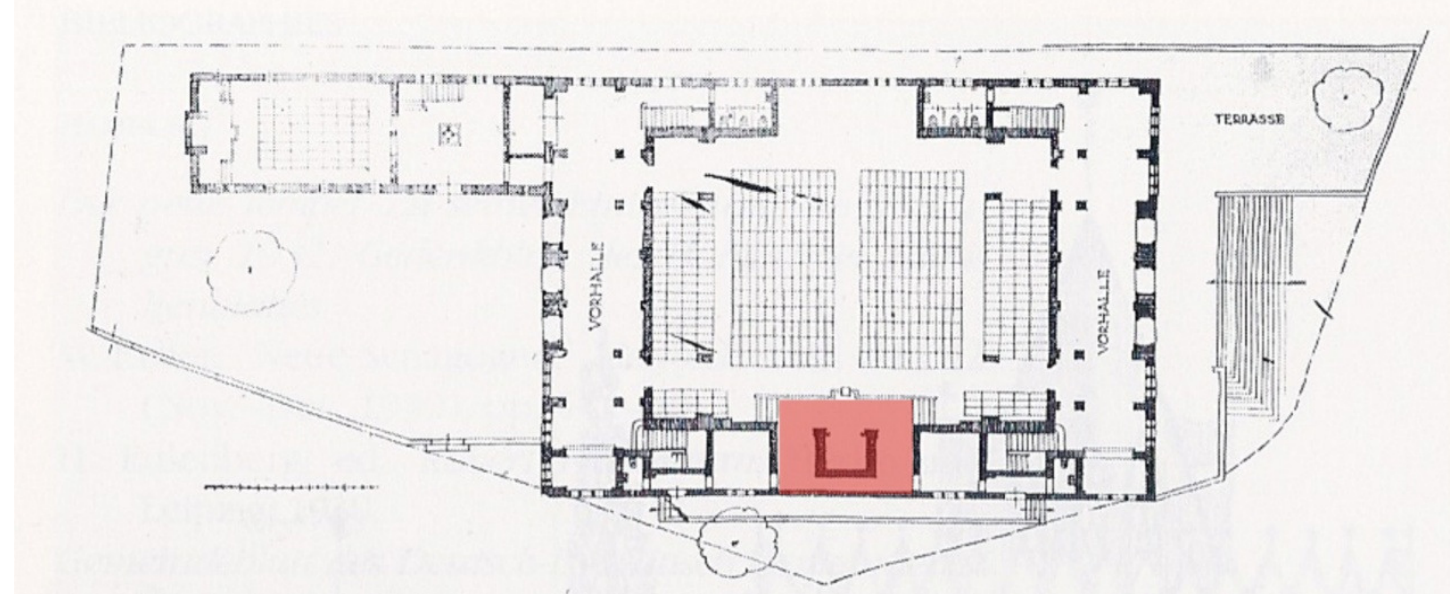

Figura 76: Planta da sinagoga de Zilina, com destaque (do autor) para a bimah junto da arca. Fonte: KRINSKY, 1996, p.307.

\subsection{Considerações}

No que se refere ao programa de necessidades, as sinagogas, surgidas durante a emancipação dos judeus, tinham grandes dimensões e diferentes instalações agregadas a si, visando demonstrar as novas condições civis, alcançadas pelos judeus, e evitar a assimilação da comunidade.

Quanto à influência da arquitetura local, a possibilidade de assimilação também levou as comunidades a adotar os estilos vigentes. As primeiras tentativas de expressar uma linguagem judaica se deram nesse período e partiram da aplicação de simbolismos nas fachadas ecléticas, mouriscas ou neoclássicas. A nascente arquitetura moderna também teve grande influência nos projetos das sinagogas, cujos princípios quanto à eliminação dos ornamentos se encaixavam perfeitamente com o caráter iconoclasta da religião judaica.

Após o movimento reformista, o espaço interno das sinagogas foi ordenado de forma a abrigar o público em forma de auditório, refletindo a disposição das igrejas protestantes, com o foco direcionado a um ministro. Na sinagoga, o foco voltava-se à bimah que estava agora disposta à frente, junto da arca, evitando barreiras visuais ou sonoras. A separação entre homens e mulheres foi diminuída ou eliminada, até o ponto de ambos os sexos poderem participar dos serviços no mesmo ambiente ou misturados. 


\section{PÓS-GUERRA}

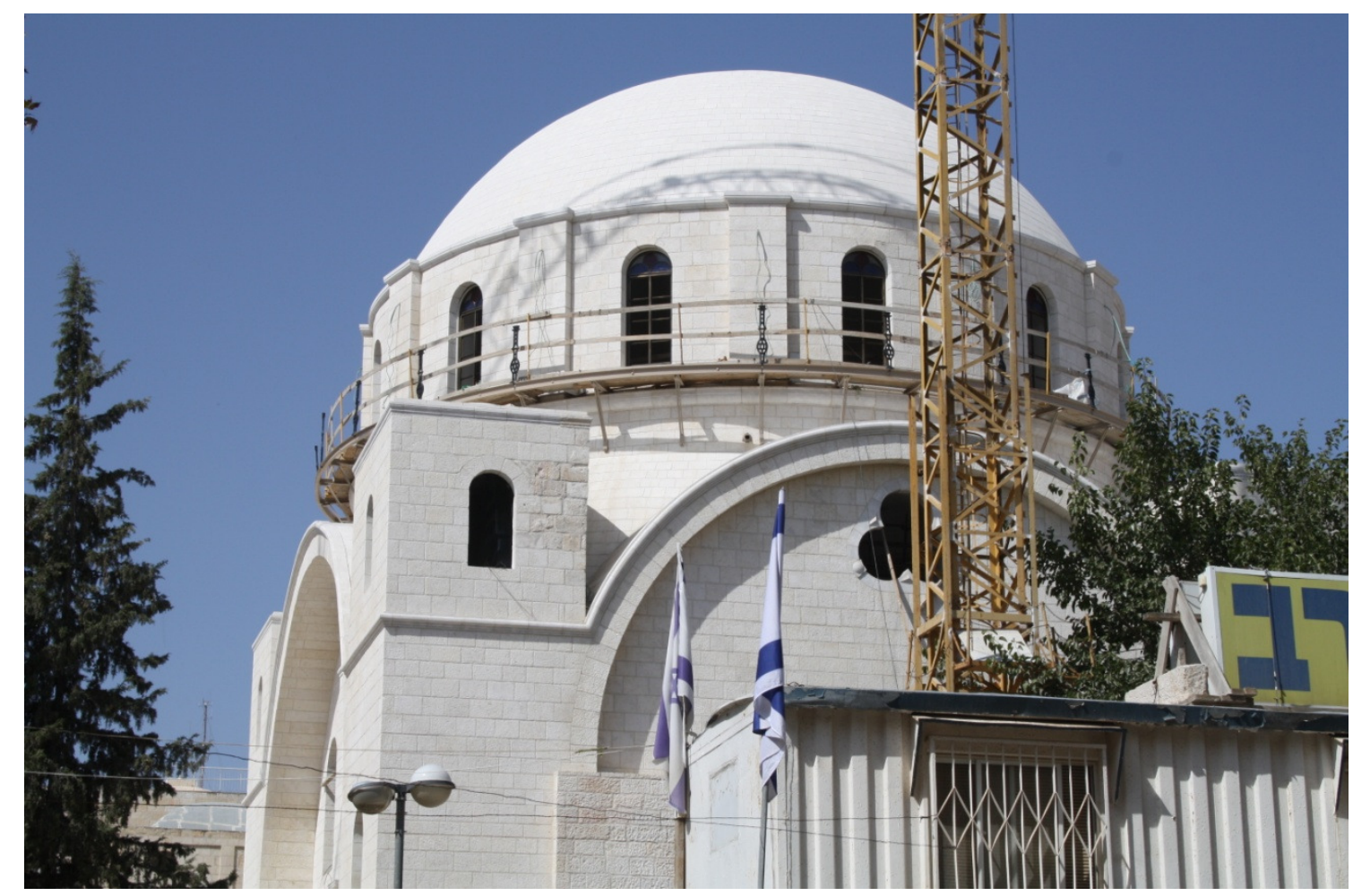

Figura 77: Edifício reconstruído em 2010 da sinagoga Hurva em Jerusalém. Foto: Sergio Rugik Gomes.

\subsection{Contexto Histórico}

Após o período de resgate da vida em sociedade, decorrente da emancipação e do movimento reformista, os judeus da Europa se encontraram diante de uma nova catástrofe. Durante a Segunda Guerra Mundial, a política genocida nazista provocou o extermínio sistemático de aproximadamente seis milhões de judeus. Gruber (2004) afirma que toda a arte e vida judaica tornaram-se completamente diferentes do que eram antes do holocausto ${ }^{68}$. Esses acontecimentos alimentaram os sentimentos em favor da criação de um estado judaico, fato oficializado pela ONU 1948.

Muitas das comunidades remanescentes da Europa imigraram para outros países, especialmente para as Américas. É nesse âmbito que também ganhou maior força o movimento sionista, que pregava a necessidade do retorno de todos os judeus para o Estado de Israel. Para exemplificar as transformações,

${ }^{68}$ Holocausto é o nome dado ao extermínio de judeus nos campos de concentração nazistas durante a Segunda Guerra Mundial. 
decorrentes desses acontecimentos, foram selecionados os seguintes edifícios: Sinagoga B'nai Amoona, EUA - 1950; Sinagoga de Livorno, Italia - 1962; Projeto para a sinagoga de Hurva, Israel - 1974; Sinagoga Cymbalista, Israel - 1998; Sinagoga da Universidade Hebraica de Jerusalém - 1957.

\subsection{Dimensões e Programa}

Antes reunidas em todo o continente europeu, agora as comunidades judaicas voltaram a se espalhar pelo mundo, definindo a atual configuração da distribuição das comunidades judaicas ao redor do mundo. $\mathrm{Na}$ Europa do pós-guerra, muitas sinagogas tinham formas compactas, como a nova sinagoga de Livorno (fig.81), projetada por Angelo di Castro, dedicada em 1962 para substituir o antigo edifício renascentista, destruído durante a guerra. Segundo Krinsky (1986), seu novo edifício foi construído em concreto por uma questão de economia.

Nas Américas, principalmente nos Estados Unidos, várias sinagogas foram projetadas como centros comunitários, procurando prover serviços sociais aos imigrantes, o que era considerada uma tarefa prioritária. Os centros comunitários também visavam atrair os jovens judeus, oferecendo instalações culturais, sociais e atléticas, evitando a assimilação cultural e os casamentos interculturais (KRINSKY, 1985). Considerada a primeira sinagoga modernista americana, o Templo B'Nai Amoona (fig.78) foi o primeiro trabalho de Eric Mendelsohn nos Estados Unidos (EKERMAN, 2007). Sua construção foi norteada pelo programa desejado pela congregação, com enfoque principal em sua função como centro comunitário. No desenvolvimento da planta houve a preocupação com a criação de um espaço flexível no salão de reuniões, que permitisse a ampliação do templo em direção aos espaços comunitários, o foyer e a sala de assembléia. As salas de aula foram alinhadas junto à fachada posterior, separadas do templo por um pátio ajardinado (JAMES-CHAKRABORTY, 2000). Em meio ao pátio, foram inseridas uma biblioteca e uma enfermaria. 


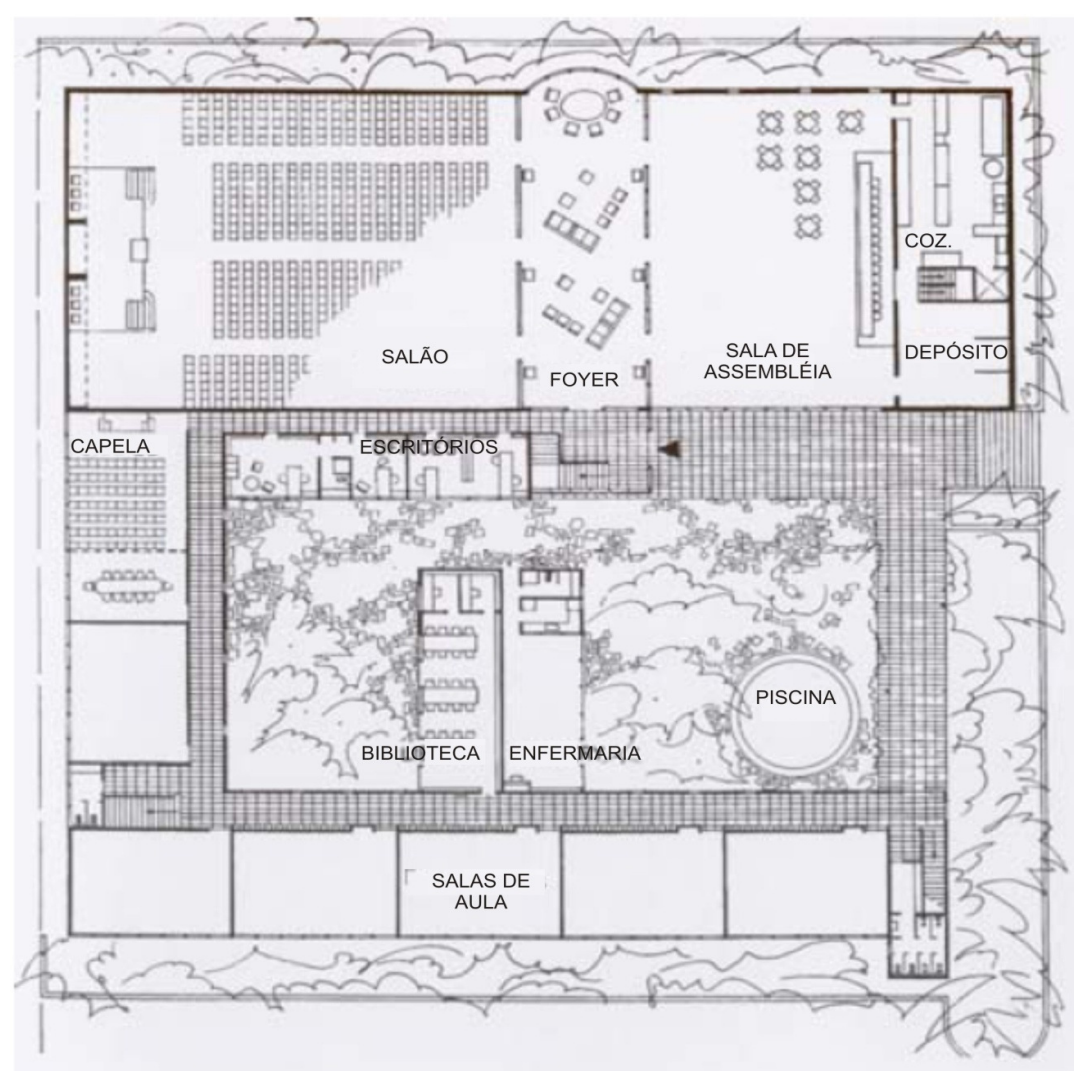

Figura 78: Planta da sinagoga B'nai Amoona, em St. Louis, Estados Unidos (editada pelo autor).Fonte: JAMES-CHAKRABORTY, 2000 in EKERMAN, 2007, p.58.

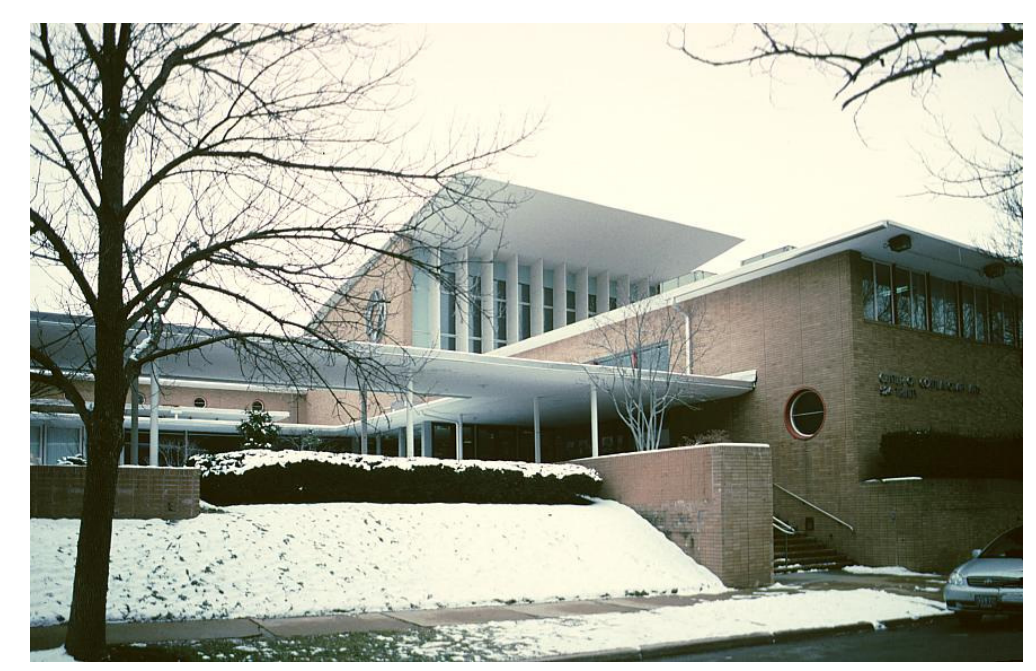

Figura 79: Fachada do complexo da sinagoga B'nai Amoona em St. Louis, Estados Unidos.

Fonte: <http://www.bluffton.edu/ sullivanm/missouri/stlouis/temple/entrance.jpg> Acesso em: 27 jan. 2011.

A sinagoga da Universidade Hebraica de Jerusalém, em Israel, inclui um salão de orações, uma biblioteca e um pátio na entrada pavimentado e descoberto (EKEMAN, 2007). Ele é acessado por meio de um pátio interno que se abre em direção à colunata. Uma escada em espiral se ergue adjacente à parte 
interna do domo, levando ao salão de orações. O edifício tem apenas uma entrada e uma porta que leva ao edifício do lavatório (DEKEL-CASPI, 2005). A arca se ergue sobre uma plataforma que repete a estrutura de toda a sinagoga e a galeria das mulheres está localizada ao longo do lado sul da cúpula.

Pode-se considerar assim que os programas e dimensões das sinagogas do pós-guerra serão adequados às suas novas localidades resultantes dos movimentos migratórios do pós-guerra. $\mathrm{Na}$ Europa as sinagogas serão compactas. Nos Estados Unidos, Centros Culturais e em Israel seguirão os programas ortodoxos, ou programas compactos seculares.

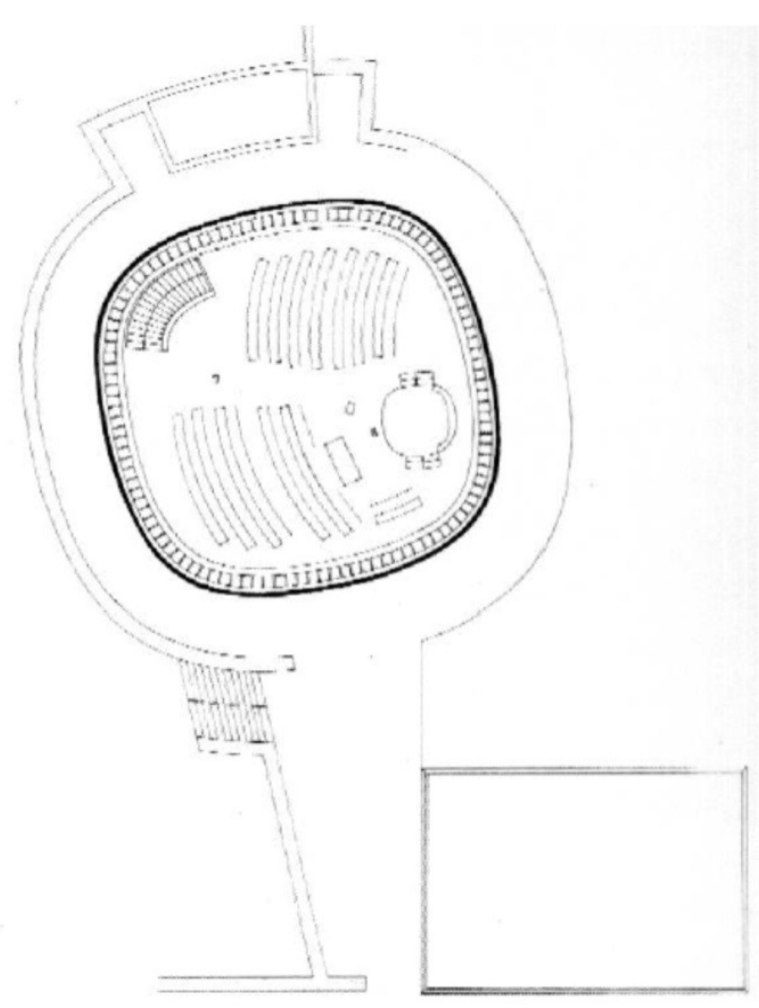

Figura 80: Planta da sinagoga da Universidade Hebraica de Jerusalém. Fonte: DEKEL-CASPI, 2005, p.43.

\subsection{Influência da Localidade e Preservação da Identidade}

Diante do quadro de destruição ocasionado pela guerra, surgiu entre as comunidades sobreviventes a necessidade de repensar sua arquitetura, abandonando os estilos historicistas que caracterizaram as sinagogas do final do século XVIII. Na Europa, durante o período de escassez econômica que seguiu ambas as guerras, havia a necessidade de uma arquitetura prática, que substituísse 
a tradicional arquitetura dos grandes edifícios. Quando sinagogas permanentes puderam ser novamente construídas, a maioria dos arquitetos já trabalhava na linguagem moderna, estabelecendo um vocabulário funcional, mas também simbólico. A luz natural, a geometria pura e o refino dos simples detalhes seriam suficientes para dignificar a sinagoga em uma nova forma de expressão, um renascimento frente ao desastre.

A arquitetura moderna foi amplamente aceita como uma forma de expressão de um renascimento após o holocausto. Além do caráter funcional, havia também a necessidade de um resgate do passado, ligado a um aspecto espiritualista. Alguns edifícios começaram assim a fazer referências a eventos bíblicos como a arca de Noé, o Tabernáculo ou o Templo de Jerusalém e ao próprio holocausto.

$\mathrm{Na}$ nova sinagoga de Livorno, as colunas de sustentação se projetam da parede para fora, para simbolicamente fazer menção ao Tabernáculo ou a uma tenda no deserto, referência que obteve mais resultado em seu interior. Sua forma exterior parece rude, mas foi concebida para ser notada, para afirmar que os judeus não foram completamente destruídos. Os vidros superiores foram pintados de vermelho para lembrar o sangue dos judeus mortos na guerra. As janelas poligonais se referem ao antigo edifício destruído, cujos remanescentes da bimah destruída também foram utilizados na construção da nova bimah.
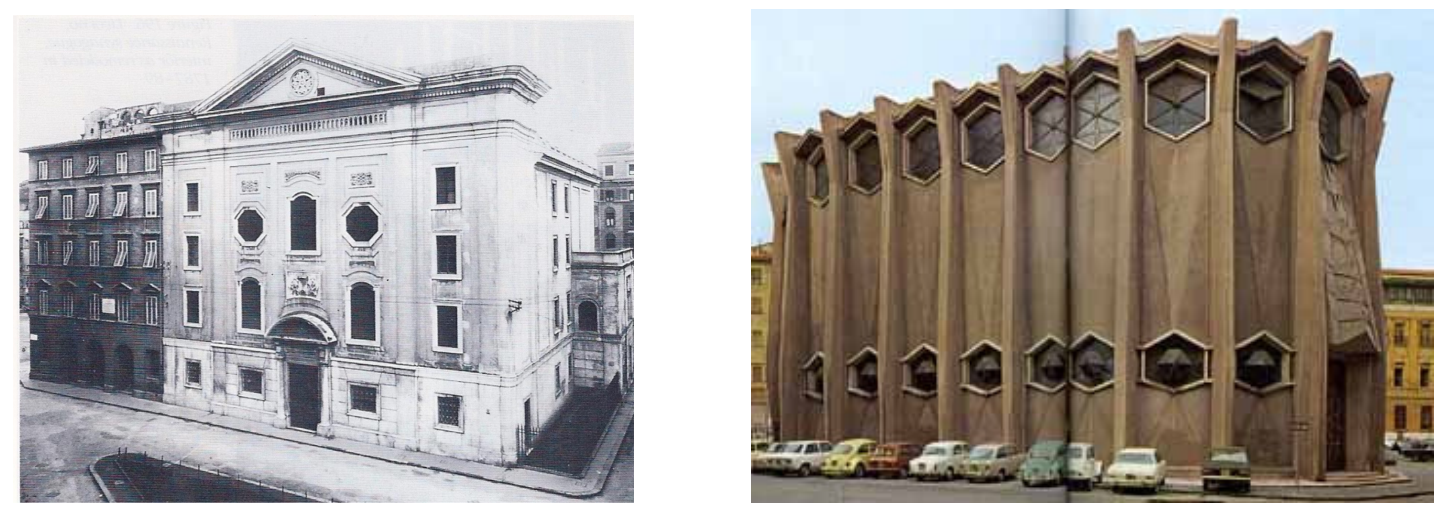

Figura 81: A sinagoga antiga renascentista em Livorno e sua substituta no pós-guerra. Fonte: KRINSKY, 1985, p.352. Fonte: <http://www.jewishvirtuallibrary.org/jsource/images/ltaly/legsyn1.jpg> Acesso em: 19 jan. 2011. 


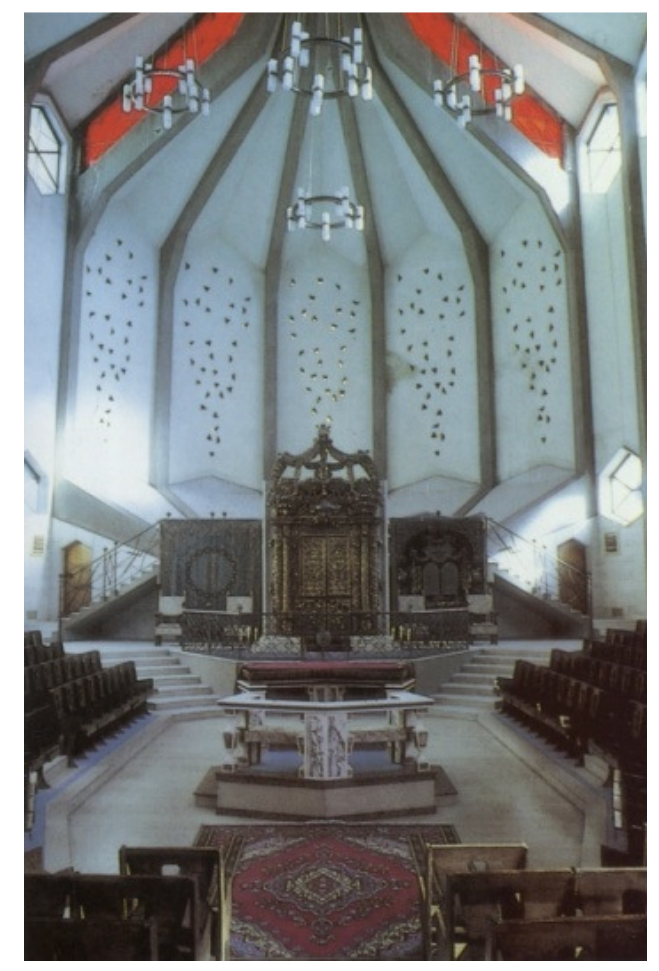

Figura 82: Interior da sinagoga de Livorno do pós-guerra.

Fonte: <http://www.jewishitaly.net/immagini/livornosynagogue.jpg> Acesso em: 19 jan. 2011.

O grande movimento migratório de judeus para as Américas fomentou um ambiente favorável à construção de edifícios, oportunizando novas formas de expressão. Especialmente nos Estados Unidos, a imigração de judeus abastados para os subúrbios causou uma explosão na construção de novas sinagogas. Arquitetos, como Percival Goodman e Erick Mendelsohn, tornaram pioneiros de uma nova linguagem nas sinagogas do pós-guerra. As funções do edifício passaram a ser traduzidas de forma mais clara no projeto, por conta do funcionalismo da arquitetura moderna.

Agora o significado de funcionalismo é que o princípio do design é a planta vivenciada, o arranjo das ações dos usuários; para seu projeto, o arquiteto deve olhar o serviço e para a congregação, empregando quais meios forem necessários para servir às suas funções da forma mais simples e direta possível (GOODMAN, 2001, p.63 - trad. nossa).

Com a criação do Estado de Israel, acirrou-se ainda mais a procura por uma identidade judaica na arquitetura dentro da busca por uma identidade nacional. Essa busca encontrou, na arquitetura moderna, o veículo adequado para a expressão de seus novos anseios. Isto pode ser traduzido no projeto da sinagoga da 
Universidade Hebraica de Jerusalém, projetada pelo brasileiro David Reznik, juntamente com Heinz Hau.

O volume principal é definido por uma casca de concreto branco, rasgada por oito arcos abatidos no pavimento térreo. O piso circular de concreto do salão foi erguido até a altura do ápice dos arcos. Ele é sustentado por oito colunas circulares distantes $60 \mathrm{~cm}$ do domo e deixando um espaço entre o domo e o piso do salão, o que permite a entrada da luz natural por trás do piso, fazendo com que o salão pareça pairar no ar.

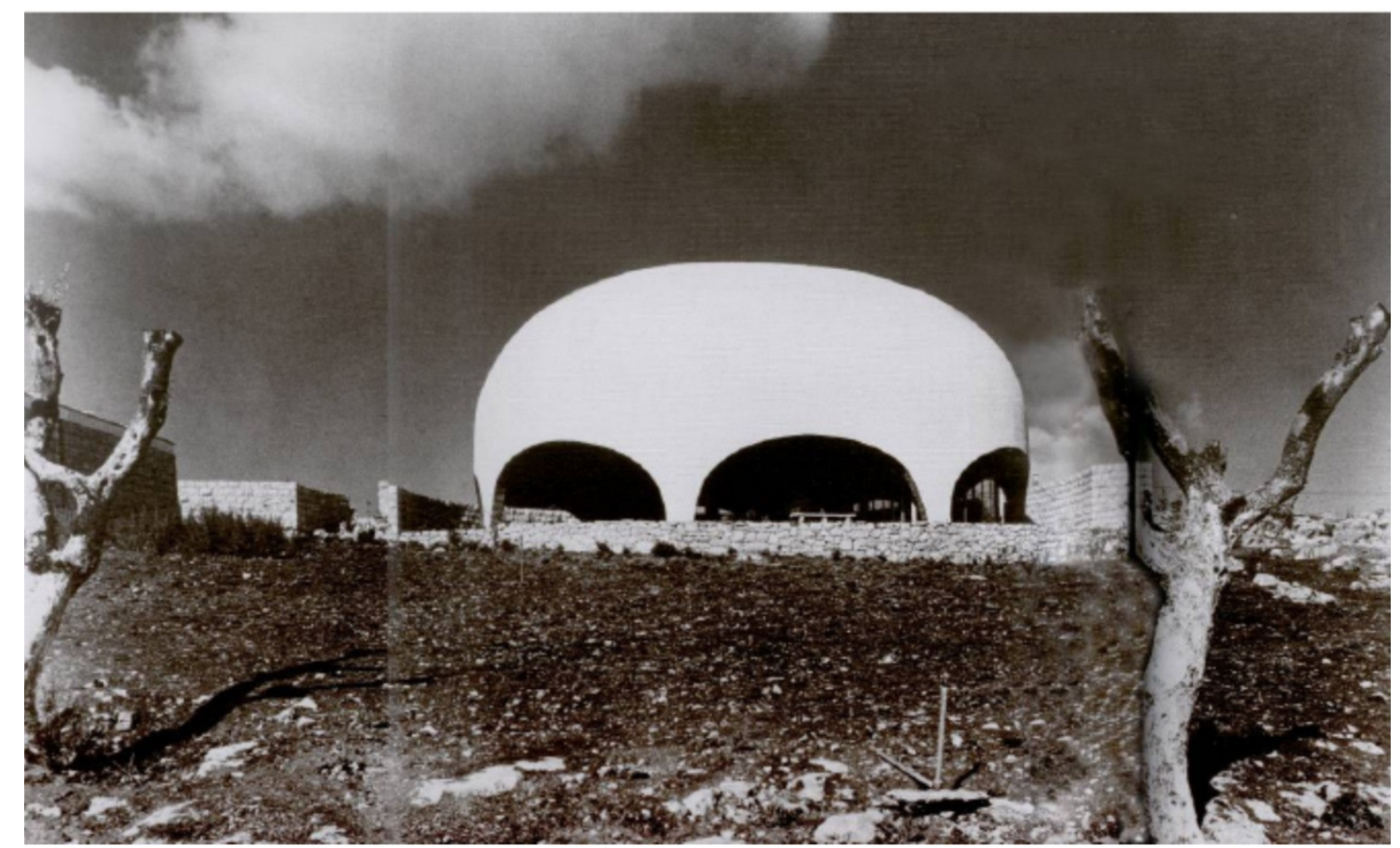

Figura 83:Fachada da sinagoa da Universidade Hebraica de Jerusalém, Israel.Fonte: DEKEL-CASPI, 2005, p.39.

\subsection{Ordenação Interna}

As novas tecnologias de construção, adotadas pelo movimento moderno, permitiram vãos maiores com livre visualização do oficiante. Essas novas possibilidades foram rapidamente aplicadas ao design das sinagogas reformistas, cujos assentos são organizados como um auditório e não há nenhum tipo de separação entre homens e mulheres, como na sinagoga B'nai Amoona. Lá as mulheres participam juntamente com a família, misturadas aos homens (fig.84). 


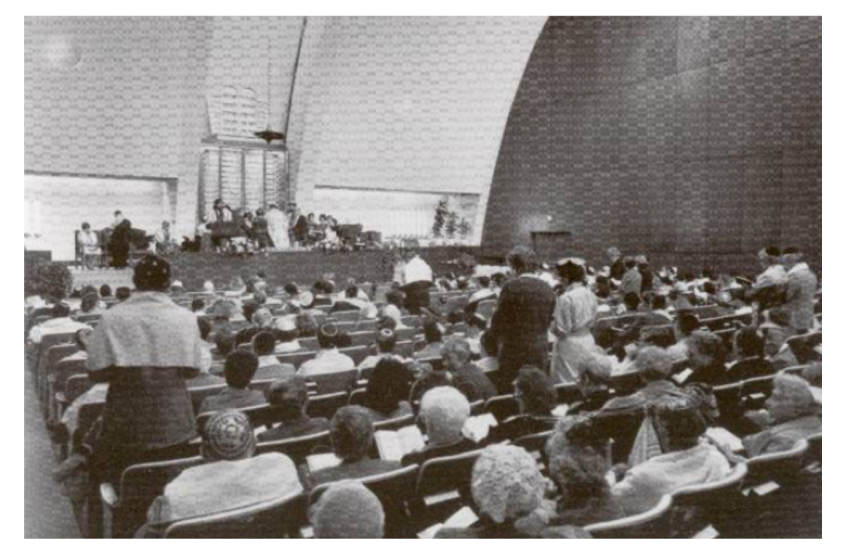

Figura 84: Interior da sinagoga B'nai Amoona em St. Louis, Estados Unidos. Fonte: JAMESCHAKRABORTY, 2000 in EKERMAN, 2007, p.57.

A ortodoxia judaica também se adaptou com facilidade ao design moderno, ao encontrar, na eliminação do ornamento, um conceito a que estava familiarizada. Sua organização interna com a bimah, afastada da arca, e a Torah junto á parede, voltada para Jerusalém, chegou a ser proposta como um "arranjo espacial original", uma possível resposta à questão da identidade judaica na arquitetura (HOLLENSTEIN, 2003).

Em Israel, os israelenses seculares $^{69}$ raramente formam congregações, de forma que os ortodoxos foram responsáveis pela maior parte das sinagogas congregacionais. Sua ordenação interna procura atender as exigências da lei judaica, como é o caso da proposta de Louis Kahn para a reconstrução da sinagoga Hurva em Jerusalém. O projeto, desenvolvido entre 1967-1974, objetivava a reconstrução do edifício destruído durante a guerra da independência em 1948, que acabou sendo reconstruída em seu estilo original em 2010 (fig.77). Ao contrário da grandiosidade dos santuários do tipo igreja das sinagogas americanas, o projeto de Kahn buscava reinterpretar o interior ortodoxo tradicional e organizar o conjunto, segundo as proporções do antigo Templo de Jerusalém - um espaço quadrado, com a bimah afastada da arca, e a área das mulheres separada com clareza por uma galeria.

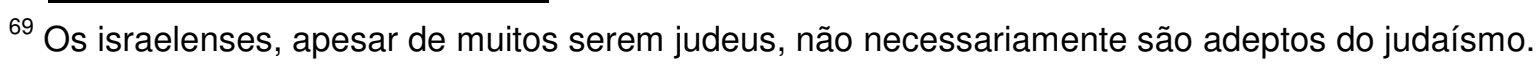




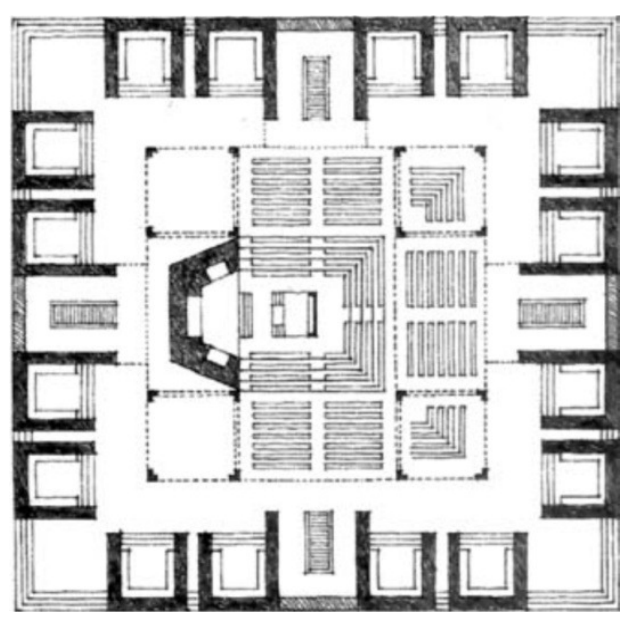

Figura 85: Planta da proposta de Loius Kahn para reconstrução da sinagoga Hurva. Fonte: $<$ http://www.stoa-architecture.com/theorie/wp-content/uploads/lmage/Histoire20.jpg> Acesso em: 07 fev. 2011

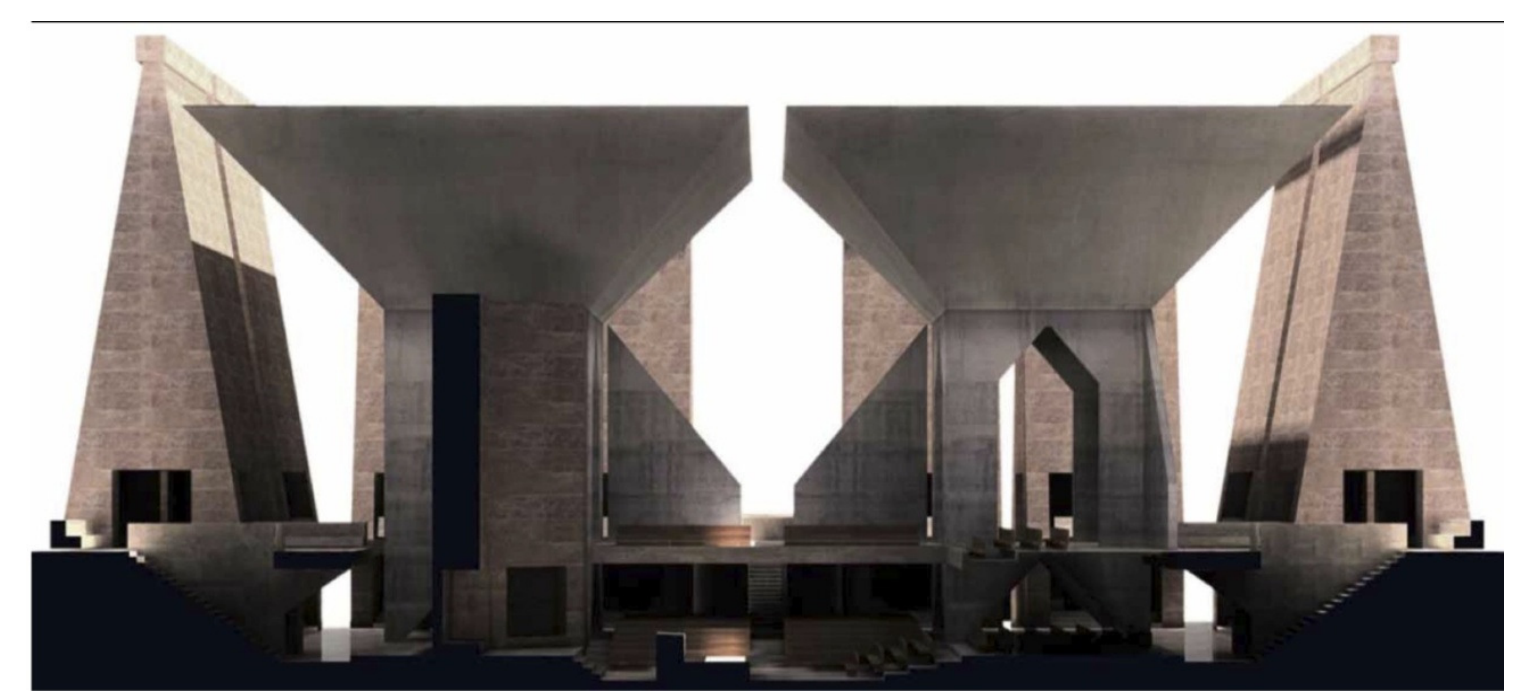

Figura 86: Seção em 3D da proposta de Louis Kahn para sinagoga Hurva. Fonte:<http://israeltours.files.wordpress.com/2011/01/model-hurva-synagogue-exterior.jpg> Acesso em: 07 fev. 2011.

Mesmo depois do movimento reformista, as diferentes tendências dentro da religião judaica deram origem a diferentes soluções para definir um espaço às mulheres, como uma pequena diferença no nível do piso ou apenas um espaço onde as mulheres sozinhas deveriam se sentar juntas. A sinagoga Cymbalista da Universidade de Tel Aviv procurou integrar, dentro de um espaço flexível, as diferentes vertentes do judaísmo (EKERMAN, 2007). Inaugurada em 1998 no campus da Universidade de Tel Aviv, seu interior possui elementos móveis, permitindo a utilização por judeus ortodoxos, liberais ou reformistas. A seção das mulheres foi prevista no foyer, cujo piso se encontra mais alto que o do salão de 
orações (HOLLENSTEIN, 2004). Sua forma exterior é composta por duas torres cilíndricas idênticas, refletindo com exatidão os espaços internos, para representar uma unidade entre o aspecto religioso do salão de orações e o secular do auditório (HOLLENSTEIN, 2003).

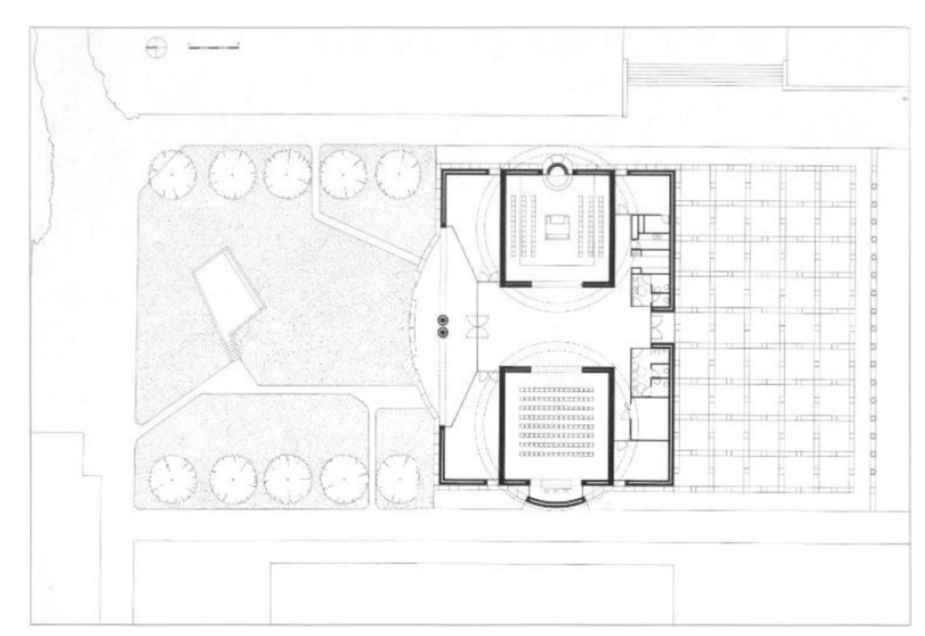

Figura 87: Planta da sinagoga cymbalista em Tel Aviv, Israel. Fonte: PELLANDINI, 2001 in EKERMAN, 2007, p.106.

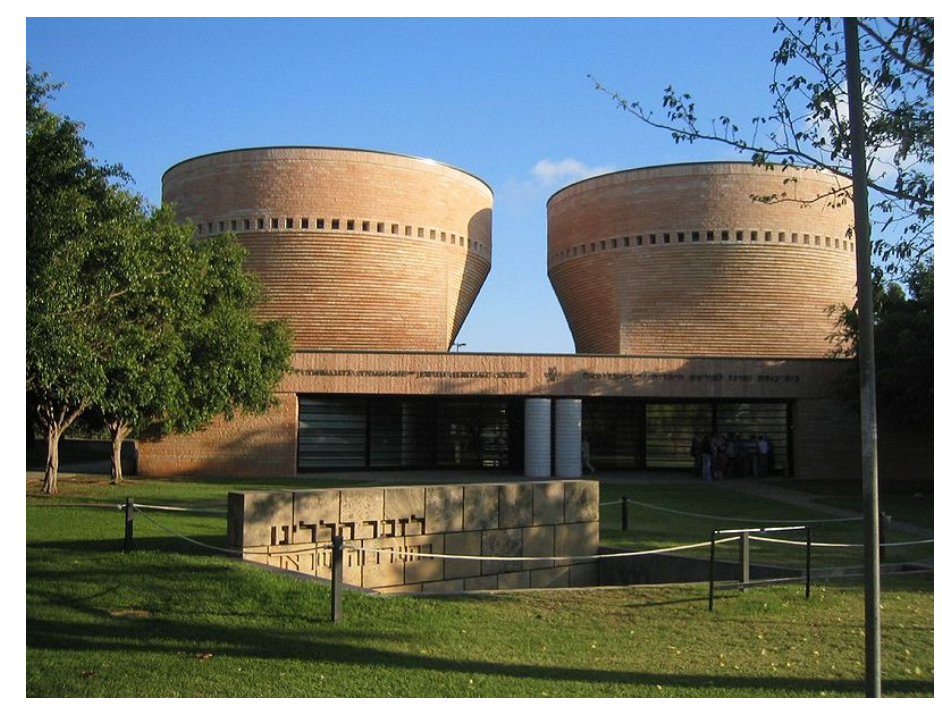

Figura 88: Fachada da sinagoga Cymbalista em Tel Aviv, Israel. Fonte: $<$ http://upload.wikimedia.org/wikipedia/commons/thumb/6/63/Synagoge auf Gelaende der Universta et Tel Aviv.jpg/800px-Synagoge auf Gelaende der Universtaet Tel Aviv.jpg> Acesso em:10 fev. 2011.

\subsection{Considerações}

Considera-se que os programas e dimensões das sinagogas do pósguerra serão adequados às suas novas localidades, resultantes dos movimentos 
migratórios desse período. Sinagogas compactas na Europa, centros comunitários nas Américas e arranjos ortodoxos em Israel.

Quanto ao estilo da localidade, a arquitetura moderna foi amplamente aceita na construção das sinagogas do pós-guerra em qualquer um dos destinos migratórios das comunidades judaicas. O funcionalismo e a eliminação do ornamento foram facilmente adaptados ao caráter iconoclasta da religião. Entretanto ainda se faziam necessárias referências que dialogassem com a origem do povo judeu e com os últimos acontecimentos, relacionados ao holocausto

No que se refere à ordenação interna dos edifícios, os vãos livres oportunizaram maiores possibilidades na organização em forma de auditório, sem barreiras visuais. Em sua ordenação interna, as sinagogas refletiam as vertentes do judaísmo moderno, com diferentes soluções no arranjo dos elementos da liturgia e na separação ou não das mulheres. 


\section{TRANSFORMAÇÕES}

O conjunto de informações sobre a sinagoga pode parecer complexo ao leitor, tendo em vista o grande período de tempo que a presente pesquisa abrange. Dessa forma, para uma compreensão global das transformações pelas quais a sinagoga passou ao longo do tempo, foi proposta a tabela abaixo como uma síntese das mudanças em cada um dos cinco períodos.

\section{Segundo Templo}

\section{Aspectos Gerais:}

- Programa: programa se resume ao salão de orações.

- Arquitetura local: elementos da arquitetura Greco-romana.

\section{Ordenação Interna:}

- Elementos da liturgia: ausentes.

- Seção das mulheres: ausente.

\section{Diáspora}

\section{Aspectos Gerais:}

- Programa: programa agrega outras funções necessárias no exílio.

- Arquitetura local: elementos da arquitetura local como, por exemplo, as aediculae.

\section{Ordenação Interna:}

- Elementos da liturgia: elementos não seguem uma disposição definida.

- Seção das mulheres: ausente.

\section{Cristianismo}

\section{Aspectos Gerais:}

- Programa: programa volta a se resumir principalmente ao salão de orações. Mais tarde vestíbulo e galerias visam atender às leis judaicas. 
- Arquitetura local: exterior discreto e interior adornado. Influência da arquitetura das igrejas na escala das sinagogas.

\section{Ordenação Interna:}

- Elementos da liturgia: organização da bimah e da arca no eixo central em relação à distribuição das colunas de sustentação.

- Seção das mulheres: surgimento de um espaço para as mulheres, inicialmente como um anexo e posteriormente nas galerias.

\section{Emancipação}

\section{Aspectos Gerais:}

- Programa: sinagogas, em grandes dimensões, capazes de abrigar milhares de pessoas com diferentes instalações de apoio.

- Arquitetura local: Sinagogas, em diversos estilos, com aplicação de simbolismos. Adoção da linguagem moderna com referenciais simbólicos.

\section{Ordenação Interna:}

- Elementos da liturgia: criação de espaços do tipo auditório.

- Seção das mulheres: eliminação do espaço para as mulheres.

\section{Pós-guerra}

\section{Aspectos Gerais:}

- Programa: sinagogas do tipo centros sociais.

- Arquitetura local: vocabulário funcional próprio da linguagem moderna.

\section{Ordenação Interna:}

- Elementos da liturgia: diferentes formas de ordenação conforme a vertente dentro da religião.

- Seção das mulheres: variadas formas de separação ou completa ausência desta. 


\section{CONSIDERAÇÕES FINAIS}

A presente pesquisa procurou apresentar um panorama das sinagogas, construídas ao redor do mundo, desde a antiguidade até os dias atuais. Isto foi feito tomando como base as transformações pelas quais sua arquitetura passou, ao procurar adaptar-se aos diversos contextos locais onde se estabeleceram as comunidades judaicas. Dispostos cinco períodos cronológicos, foram selecionados edifícios que pudessem demonstrar as transformações geradas pelas condições impostas por cada momento histórico. Dentro de cada período, as sinagogas foram analisadas a partir de três aspectos: do programa de necessidades, da influência da localidade e preservação da identidade e da ordenação interna do edifício.

Quanto ao programa do edifício, as sinagogas contemporâneas ao Templo de Jerusalém, edifício que tinha importância central no estilo de vida e cultura do povo judeu, apresentavam um programa resumido, principalmente ao salão de orações, pois é possível que a existência de Israel como nação e a presença do Templo dispensasse à sinagoga um caráter sagrado ou mantenedor da identidade. Já depois da diáspora, as sinagogas começam a agregar a si outras instalações como cozinhas, salas de refeição ou vestíbulo, talvez pela necessidade de atender a algumas exigências da religião ou também pela influência dos edifícios públicos locais que dispunham de instalações similares.

Durante os séculos de ascensão do catolicismo, sob a opressão de um regime de segregação, as comunidades judaicas voltam a edificar sinagogas com um programa simplificado ao salão de orações, com a adição agora do vestíbulo e de um anexo ou galeria para as mulheres. Com o advento da emancipação dos judeus, as sinagogas passaram por uma grande transformação. Os edifícios agora procuravam atender a diversas necessidades da congregação, somando ao seu programa diversas instalações de apoio aos ministros, a casamentos e a outros eventos, etc. Nos pós-guerras, os programas dos edifícios vão se adequar às novas regiões para onde caminham os movimentos migratórios, como centros sociais nas Américas, programas ortodoxos em Israel.

A influência da arquitetura local, bem como as ações de preservação da identidade são visíveis em todos os períodos, com exceção nas sinagogas contemporâneas ao Templo de Jerusalém, onde aparentemente não havia risco de 
assimilação. Apesar disso, é bastante visível a influência da cultura greco-romana na arquitetura desse período e consequentemente em suas sinagogas. Na diáspora, essa influência se torna ainda maior pela imersão das comunidades em outras localidades dentro do império romano. Nesse momento começam a ser feitas referências ao Templo como forma, porém, de agregar um caráter mais sagrado ao edifício, diferente das simples sinagogas comunais da Palestina no período anterior, e pode ter sido uma reação à influência dos templos politeístas. Depois da ascensão do cristianismo, o movimento foi inverso. Havia a necessidade de uma negação da arquitetura cristã, com a aplicação dos elementos que clarificassem a lei judaica, como a orientação para Jerusalém, a cota mais alta do vestíbulo ou a criação de um anexo para as mulheres. Com a emancipação, há uma flexibilização desses princípios.

Apesar disso, a maior parte das sinagogas procura resgatar uma identidade no uso de estilos que remetessem a sua origem no oriente na aplicação de símbolos religiosos. No pós-guerra, talvez a arquitetura moderna tenha sido neutra o suficiente para servir de veículo uma expressão de identidade, ligada ao renascimento do judaísmo pós-holocausto, em que, em meio a referenciais simbólicos, a funcionalidade do edifício é a principal ferramenta de promoção do estilo de vida judaico.

Quanto à ordenação interna dos elementos da liturgia, tais elementos não estavam presentes nas sinagogas construídas durante o período do Templo de Jerusalém. Aparentemente a arca e a bimah surgiram com o passar do tempo, como respostas a necessidades específicas e à influência de contextos locais. Após a diáspora, a mesa na sinagoga de Sardes ou a plataforma em Ostia podem ser um exemplo do que viria a se tornar a bimah. As aediculae podem ter precedido a arca medieval que passaria a ser um nicho na parede. Durante o período cristão, a orientação do edifício também parece ter recebido maior atenção, pois, por causa da cidade de Jerusalém, a parede da arca deveria estar orientada para o leste, para onde deveriam ser dirigidas as orações. A arca e a bimah deveriam estar separadas, para evitar qualquer similaridade com os templos cristãos. Este princípio foi abandonado durante o movimento reformista, quando as sinagogas eram organizadas como um auditório e a arca e a bimah estavam dispostas juntas no foco principal do edifício, como nas igrejas cristãs. 
Um fato interessante, relacionado, às mulheres na sinagoga da antiguidade, é que, pelo que indicam os achados arqueológicos, as mulheres tinham participação ativa nos serviços e não havia separação entre homens e mulheres. Essa configuração parece se estender após a diáspora, mudando apenas após a ascensão do cristianismo na idade média, talvez para atender às determinações da lei judaica. Essa separação é flexibilizada ou até extinta durante a emancipação por conta das mudanças trazidas pelo movimento reformista e ratificada durante o pósguerra. Apesar disso, o pós-guerra é caracterizado pela diversidade de soluções quanto à localização das mulheres, conforme as diferentes linhas de pensamento dentro do judaísmo.

Um comportamento que pode ser observado no decorrer do tempo, relacionado à arquitetura das sinagogas, é a relação entre a influência da localidade e as ações de preservação da identidade, um constante conflito entre assimilação e preservação. Aparentemente, durante vinte séculos de produção, as sinagogas não chegaram a formar uma linguagem em sua arquitetura. $O$ que parece ter ocorrido foi uma contínua adaptação dos edifícios às arquiteturas locais para onde migraram as populações judaicas. Levine (2005) confirma essa posição ao assegurar que o povo judeu não possuía uma tradição arquitetônica independente, tanto no âmbito público, como no privado.

Como resultado disso, teve de emprestar dos estilos arquitetônicos vigentes das sociedades a ele contemporâneas os elementos de sua arquitetura. Krinsky (1996, p.20 - trad. nossa) também confirma a inexistência de uma linguagem judaica, entretanto atribui isto às condições econômicas e às determinações da lei judaica, que levaram os judeus a não desenvolverem um saber arquitetônico.

Em circunstâncias tão humildes e incertas, eles estavam desacostumados a pensar sobre arquitetura. Além disso, o Talmud recomenda que se seja desatento ao entorno durante a oração. Estes fatores atrapalharam 0 desenvolvimento de uma tradição arquitetônica judaica.

Goodman (2001) atribui isto a diferentes tipos de rito dentro do judaísmo. Ekerman (2007, p.31), na mesma linha, explica demonstrando a multiplicidade de orientações quanto à forma de se viver o judaísmo, sem uma 
hierarquia clerical organizada ou comando central, coexistindo diferentes pensamentos em como se vivenciar a religião, sua liturgia e vida cotidiana.

\begin{abstract}
Os principais grupos nos dias atuais são os ortodoxos, os conservadores os liberais e os reformistas, orientações que variam na sua maneira de enxergar as restrições da lei judaica tradicional com respeito à alimentação (as leis de Kashrut) e a maneira de se vestir ou de comportar-se durante o shabat (sábado), por exemplo. Desta forma, podemos observar que poucas são as regras rígidas de conformação da liturgia e do espaço religioso judaico. É mais apropriado falarmos de elementos para uma liturgia judaica, que ao longo da história receberam diferentes tratamentos e organizações, resultando assim em espaços distintos. Esta heterogeneidade é uma característica histórica da sinagoga e ainda hoje persiste a dúvida sobre os caminhos para a consolidação de um arranjo universal destes elementos litúrgicos.
\end{abstract}

Entretanto, apesar de historicamente não terem desenvolvido um saber arquitetônico como espaço formal, em suas contínuas peregrinações a diferentes contextos, os judeus desenvolveram sua ação. Foi esta ação que configurou seu espaço interno na ordenação dos elementos da liturgia, arca, bimah e congregação, dando assim sua identidade ao espaço. Abraham Joshua Heschel, um influente teólogo e filósofo judeu de origem hassídica, afirma que “(...) 0 judaísmo é uma religião do tempo, que visa à santificação do tempo". Quanto aos sábados, explica, "são nossas grandes catedrais" (apud BIZON, 2005). Nesse sentido, ao mencionar Heschel, Falbel (2007) defende que a presença de Deus e assim da própria eternidade depende das ações do homem, de sua constância no culto e no estudo da Torah. Nesse sentido, o Deus de Israel não possui endereço geográfico ou uma residência permanente, mas se faz presente nos eventos, nos atos, no tempo e na história.

Zevi (2002, p. 19), afirma que:

O problema espaço-tempo é mais dificultoso em arquitetura, visto que por milênios o homem sentiu pavor não somente do tempo, mas também do espaço, do vazio, da cavidade, ou seja, do elemento específico representativo da arquitetura. Por milênio desde a pré-história até 0 Pantheon, o espaço foi sentido como negatividade, e o homem construiu monumentos e templos neles privilegiando o aspecto plástico, escultórico, de grandes dimensões, e descuidando ou reprimindo o conteúdo. A consciência espacial nasce com extremo atraso na história e na experiência humana: ainda hoje a maior parte das pessoas, mesmo as cultas, não tem nenhuma sensibilidade espacial, detendo-se no invólucro, na caixa construída, sem ver o espaço. 
Assim, a organização interna da sinagoga ortodoxa askenazita foi considerada por Korn (apud. Hollenstein (2003)) "um arranjo espacial original", e Goodman (2001) afirma que, nesta organização interna da sinagoga, manifesta-se uma tradição essencialmente judaica, baseada nas ações desempenhadas dentro do edifício: "entretanto há uma tradição na sinagoga: a tradição do serviço, dos objetos sagrados e do mobiliário [...] das funções congregacionais do edifício."

Ekerman (2007) explica que ao longo da história podem-se identificar três disposições básicas no arranjo interno da sinagoga. A primeira de origem asquenazita, ou seja, dos judeus oriundos da Europa oriental, França e Alemanha, traz a bimah ao centro e a arca encostada na parede orientada a leste, direção do antigo Templo. A segunda disposição, de origem sefaradita, dos judeus originários da Península Ibérica, foi fruto da tentativa de resolver a bipolaridade, ocasionada pela separação entre a arca e a bimah, situando-as em lados opostos com a entrada localizada na parede norte ou sul. $O$ terceiro esquema surge em meio ao movimento reformista do início do século XIX, movimento que procurava reagir à assimilação cultural que se deu em meio à laicização dos estados europeus e consequente emancipação dos judeus. Nesse esquema, a bimah une-se à arca na face leste do edifício, para onde agora toda a atenção é dirigida, assemelhando-se mais aos templos cristãos.
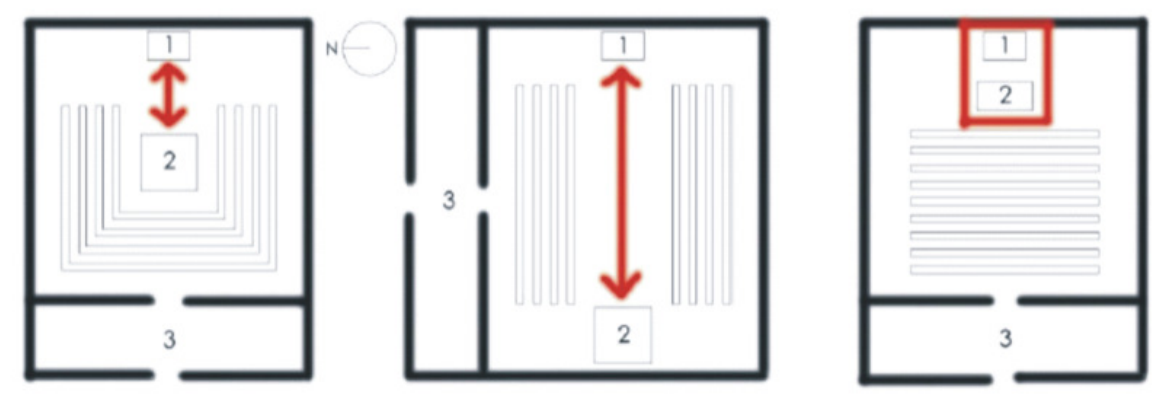

Fig.: Os três diferentes esquemas de distribuição interna da sinagoga, onde 1: arca, 2: bimah e 3: acesso pelo vestíbulo. Fonte: EKERMAN, 2007, p.29.

Entretanto, como mencionado em relação às sinagogas contemporâneas ao Templo de Jerusalém, não traziam em seu arranjo nem a arca, nem a bimah. É a partir da diáspora que vão surgir os primeiros indícios de um tipo de arca, na forma das aediculae. Dessa forma, apesar da arca estar conceitualmente ligada ao Templo de Jerusalém, é possível que sua origem seja fruto da influência dos templos politeístas, espalhados por todo o território romano, 
cujas estruturas eram construídas para abrigar os ídolos, tendo sido adaptadas às sinagogas para abrigar os pergaminhos da Torah, como em Sardes, Ostia e Dura Europos. Para essas comunidades, não representava uma forma de idolatria, mas apenas uma adaptação do contexto arquitetônico local à realidade do culto sinagogal.

Esse contexto local pode ter levado as comunidades à necessidade de acrescentar um caráter sagrado à sinagoga, adaptando elementos que trouxessem uma noção de sacralidade, o que também pode justificar outras referências ao Templo, juntamente com a necessidade de preservação da identidade. $O$ espaço para as mulheres também pode ter sido criado como uma forma de reinterpretar a arquitetura do templo. Nesse caso, as evidências arqueológicas das sinagogas antigas ou da diáspora também não trazem nenhuma evidência de alguma separação entre homens e mulheres. O caráter prático e racional do judaísmo antigo não reforça a ideia de que houvesse razões normativas ou ritualísticas para a separação dos sexos (KRINSKY, 1996).

Após o movimento reformista, a sinagoga assume um esquema similar ao das igrejas cristãs, em que a sacralidade está mais ligada ao espaço, e também se faz uma reinterpretação do Templo (fig.89-90), tendo no altar o ponto mais sagrado do edifício, ante o qual o ministro parece assumir o ofício de um novo tipo de classe sacerdotal, um intermediário entre o povo e a arca.

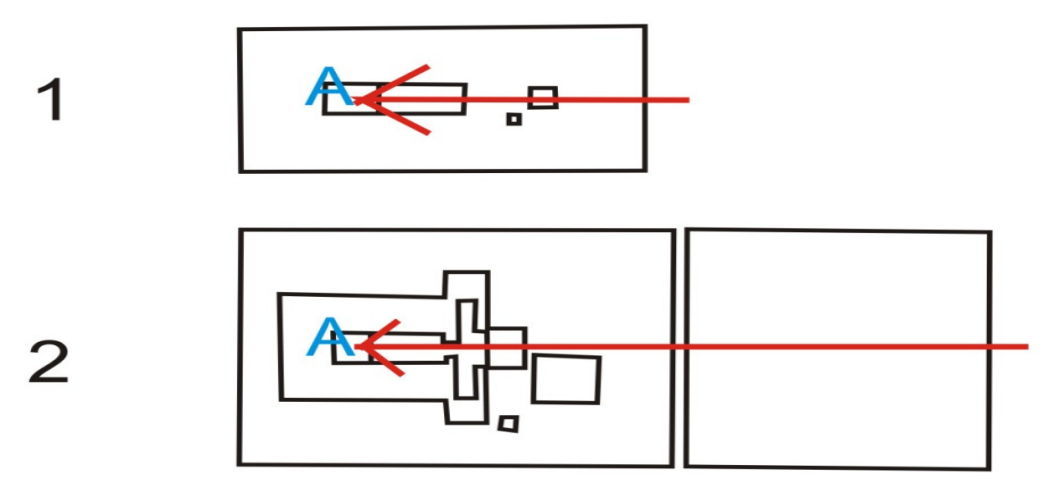

Figura 89: Desenhos esquemáticos do Tabernáculo (1) e do Templo (2) com destaque para a Arca (A). Fonte: Sergio Rugik Gomes 
Com o movimento moderno, novas formas de expressão trouxeram possibilidades de expressão de uma linguagem judaica através da arquitetura. Entretanto o Estilo Internacional pode ter representado mais uma vez uma adaptação a um contexto externo, agora, com a particularidade desse contexto ser neutro, não estar mais limitado a uma localidade e, mesmo que a planta funcional traduza características de uso da comunidade judaica e os referenciais simbólicos possam resgatar passagens da história dos judeus, as sinagogas reformistas com a bimah junto à arca se assemelhem mais às igrejas do que a um tipo de espaço judaico. No que se refere a esse arranjo, Carol Krinsky (1996, p.24 - trad. nossa) afirma que:

a congregação não mais tinha de participar continuamente e o espaço
congregacional não era mais um fórum para a dinâmica inter-relação
pessoal por entre a tensão axial e a força centrífuga emanando da bimah.
Com uma simples e estática culminação direcionada à leste, o interior
tornou-se teatral ou cerimonial e especialmente de um espaço tipo-igreja
para uma massa de pessoas. Sentados silenciosos e em assentos fixos,
membros da congregação podiam distrair sua atenção do distante oficiante,
da mesma forma que poderiam ignorar o ato de uma peça teatral.

Apesar de a bimah unir-se à arca a partir do movimento reformista, desde a diáspora parece ser possível identificar uma mudança em relação às sinagogas da Palestina contemporâneas ao Templo de Jerusalém. Estando os assentos organizados frente a frente ou não, a arca torna-se o elemento direcionador do foco do edifício. 


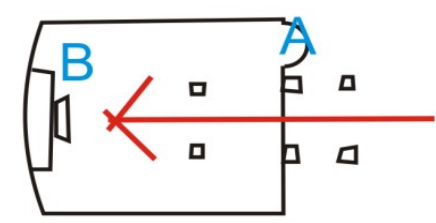

3

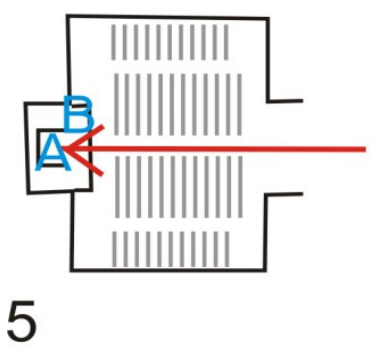

4
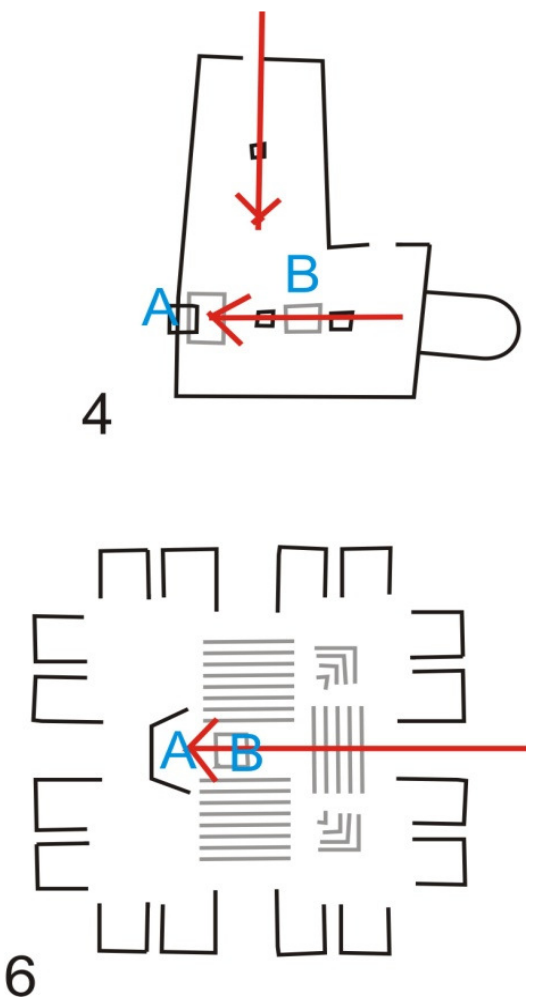

Desenhos esquemáticos das sinagogas de Ostia (3), Worms (4), Zilina (5) e proposta de Louis Kahn para Hurva (6), respectivamente, com destaque para arca (A) e bimah (B).

Nas sinagogas contemporâneas ao Templo, como mencionado, não estavam claramente definidas a bimah nem a arca. O que caracterizavam esses edifícios era exatamente seu foco na reunião comunitária, na configuração própria para reuniões e para um espaço onde todos poderiam participar. Quanto ao tipo de ordenação cujos assentos voltam-se uns para os outros, Krinsky (1996, p.22 - trad. nossa) afirma que:

Os fiéis ficam de frente uns para os outros, estabelecendo assim contato pessoal. A troca de olhares e gestos através do salão, a divisão de atenção entre a direita e a esquerda estabelecem certa equivalência ou unidade ao ambiente porque importância é dada para todas as partes. Mesmo havendo os dois focos de atenção, o movimento das mãos, olhos e corpos estabelecem correntes de movimento que ligam as partes da sinagoga e as pessoas em meio a ela. 

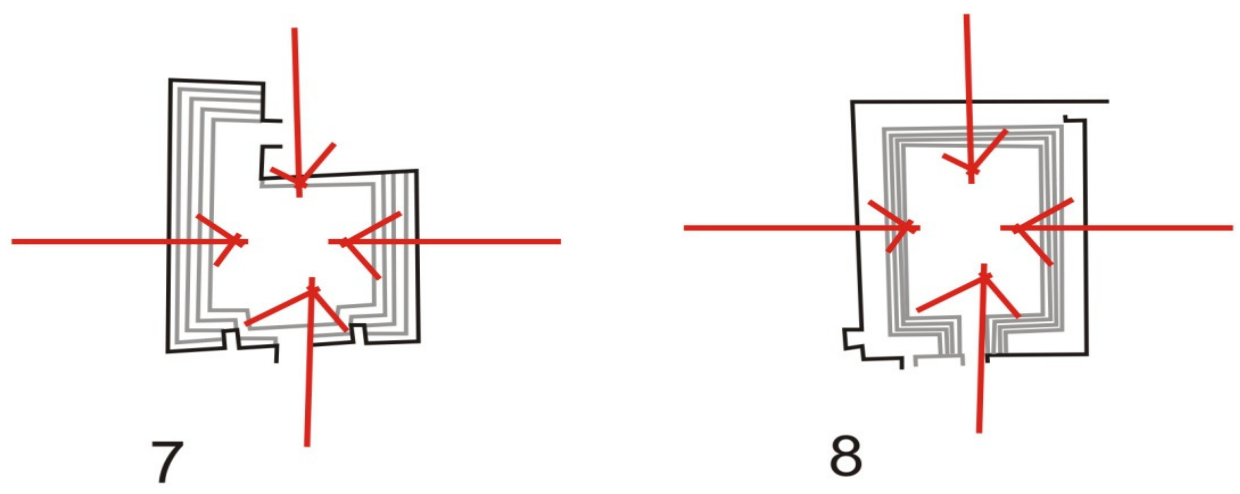

Nas sinagogas contemporâneas ao Templo, a presença deste último parecia dispensar a sinagoga da responsabilidade em assumir um caráter sagrado. Talvez essa ordenação interna da sinagoga, voltada à reunião comunitária, com os assentos dispostos de frente uns para os outros, possa revelar um espaço essencialmente judaico, $\mathrm{O}$ foco, nas orações em conjunto, na leitura coletiva da Torah e no espaço voltado ao debate com caráter sagrado, permanece relacionado unicamente ao Templo e a sinagoga, revestida de uma simplicidade comunal. 


\section{REFERÊNCIAS}

ARGAN, Giulio Carlo. Projeto e destino. São Paulo: Ática, 2004.

BARON, Salo W. História e historiografia do Povo Judeu. São Paulo:

Perspectiva,: 1974.

BÍBLIA HEBRAICA. Livro de Daniel. São Paulo: Sefer, 2006

BIBLIA HEBRAICA. Livro de Êxodo. São Paulo: Sefer, 2006.

BIZON, José [org.]. Diálogo católico-judaico no Brasil: Comissão Nacional de

Diálogo Religioso Católico-Judaico. São Paulo: Loyola, 2005.

COHEN, Stuat; HURTT, Steven. The pilgrimage Chapel at Ronchamp: Its Architectonic Structure and Typological Antecedents. in: Frampton, KENNETH. OPPOSITIONS Ed. 18-22. New York: Institute for architecture and urban studies, 1980.

DEKEL-CASPI, Sofia (Org.). David Reznik: A Retrospective. Tel Aviv: The Genia Schreiber University Art Gallery, 2005.

DIÉGUES JUNIOR, Manuel. Etnias e Culturas no Brasil. Rio de Janeiro: Biblioteca do Exército, 1980.

EKERMAN, Sergio. Sinagogas do Pós-Guerra. 1950-2007. Salvador: Universidade Federal da Bahia, 2007. 233 p. Dissertação (Mestrado) - Programa de PósGraduação em Arquitetura e Urbanismo, Faculdade de Arquitetura, Universidade Federal da Bahia, Salvador, 2007.

FALBEL, Anat. Como cantaríamos o canto do Senhor numa terra estrangeira? Revista do Arquivo Histórico Judaico Brasileiro, São Paulo, №37, ano X, maio de 2007. p. 21-28.

FALBEL, Nachman. Judeus no Brasil: Estudo e Notas. São Paulo: Humanitas; Edusp, 2008.

FINE, Steven. Where God dwells: a child's history of the synagogue. Los Angeles: Torah Aura Productions, 1999.

EISEN, Arnold M. GALUT: Modern Jewish Reflections on Homelessness and Homecoming, Indiana: Indiana University Press Bloomington, 1986.

GOODMAN, Paul; GOODMAN, Percival. Tradition from Function. In: ELMAN, Kimberlgy J.; GIRAL, Angela. Percival Goodman: Architect, Planner, Teacher, Painter. New York: Miriam and Ira D. Wallach Art Gallery, Columbia University, 2001. p. 62-65. (artigo reimpresso da revista Commentary - Junho 1947): 542-44.

GREGOTTI, Vittorio. Território da arquitetura. (Trad.). Berta Waldman-Villá. São Paulo: Perspectiva, 1975. 
GRUBER, Samuel D. Jewish Identity and Modern Synagogue Architecture. In: Jewish identity in Contemporary Architecture. Berlin: Prestel, 2004. p. 21-31.

IZECKSOHN, Isaac. Os Marranos Brasileiros. São Paulo: Impres, 1967.

HOLLENSTEIN, Roman. Sacred Builidings. A design manual. Berlin: Birkhauser, 2008.

JAMES-CHAKRABORTY, Kathleen. In the Spirit of Our Age: Eric Mendelsohn's B'nai Amoona Synagogue. St. Louis: Missouri Historical Society Press, 2000.

JOSEFO, Flavio. História dos Hebreus. Rio de Janeiro: Casa Publicadora das Assembléias de Deus, 8 ed., 2004.

KRINSKY, Carol Herselle. Synagogues of Europe. Architecture, history, meaning. New York: Dover Publications Inc, 1996.

LEVISKY, Adriana Blay. Sinagogas: a sacralização do espaço\&e espacialização do sagrado. São Paulo. Universidade de São Paulo, 2000. 217 p. Dissertação (Mestrado). Programa de Pós-Graduação Departamento de Letras Orientais, Universidade de São Paulo. São Paulo, 2000.

LE CORBUSIER. Hacia una Arquitectura. 2 ed. Barcelona: Poseidón, 1977

LEVINE, Lee I. The Ancient Synagogue. The first Thousand Years. London: Yale University Press, 2000.

MARKMAN, Sidney David. Jewish remnants in Spain: wanderings in a lost world. Scribe Publichers. Mesa, 2003.

MARONI, Monica. L'Ebraismo. Alla scoperta della storia, la fede e la cultura che hanno formato il moderno mondo ebraico. Bologna: S.p.A, 2005.

MARTÍNEZ, Alfonso Corona. Ensaio sobre o projeto. (Trad.) Ane Lise Spaltemberg. Brasília: Unb, 2000.

OLITZKY, Kerry M. The American Synagogue. Westport: Greenwood Press, 1996.

PARSONS, John J. Torah sheba'al Peh. Disponível em: <www.hebrewforchristians.com>. Acesso em: 20 dez. 2010.

RYKWERT, Joseph. A casa de Adão no Paraíso. A idéia da casa primitiva na história da arquiteura. São Paulo: Perspectiva, 2003.

SEREBRENICK, Salomão \& LIPINER, Elias. Breve História dos Judeus no Brasil. Rio de Janeiro: Biblos, 1962.

SMITH, Albert C. Architectural Model as Machine: A new view of models from antiquity to the present day. Oxford: Elsevier, 2004. 
VAN VOOLEN, Edward. From Time to Place. Shaping Memory in Judaism. In: Jewish identity in Contemporary Architecture. Berlin: Prestel, 2004. p. 12-20.

ZEVI, Bruno. Arquitetura e Judaísmo: Erich Mendelsohn. (Trad.) e notas Anat Falbel. São Paulo: Perspectiva, 2002.

WIZNITZER, Arnold. Os Judeus no Brasil colonial. São Paulo: Livraria Pioneira Editora, 1960.

WOLFF, Egon \& WOLFF, Frieda. Fatos Históricos e Mitos da História dos Judeus no Brasil. Ensaios, conferencias e Artigos. Rio de Janeiro: Instituto Histórico e Geográfico Brasileiro, 1996. 


\section{ÍNDICE DE FIGURA}

Figura 1: Sinagoga Beit Shlomo na Galeria Victorio Emanuelle em Milão, Italia. Foto: Sergio Rugik Gomes............................................................. 9

Figura 2: Sinagoga Chesed-El em Cingapura. Foto: Sergio Rugik Gomes........ 9

Figura 3: Croqui de Le Corbusier do Tabernáculo de Moisés. Fonte:<http://www.ufrgs.br/propar/publicacoes/ARQtextos/PDFs_revista_12 103_SC_ronchamp_30409.pdf> Acesso em: 22dez. 2010 .

<Figura 4: Croqui do memorial para os seis milhões de mártires judeus de autoriadeLouisKahn.

Fonte:<http://www.design.upenn.edu/archives/majorcollections/kahn/martyr splan.gif> Acesso em: 30 dez. 2010.

Figura 5: Interior da sinagoga Santa Maria la Blanca, em Toledo, Espanha. Fonte: <http://farm1.static.flickr.com/172/440520487_001bf3f456.jpg> Acesso em: 04 jan. 2011.

Figura 6: Desenhos do Tabernáculo de Moisés de autoria de Le Corbusier (legenda do autor). Fonte: CORBUSIER (1973).

Figura 7: Réplica em tamanho real do Tabernáculo de Moisés no Neguev, Israel.Fonte:<http://www.bibleplaces.com/images/Tabernacle_with_altar_12 9-09tb.jpg > Acesso em: 04 jan. 2010.

Figura 8: Modelo do Templo de Herodes, construído para substituir o Templo de Salomão, em exposição permanente no Museu de Israel, Jerusalém, Israel. Foto: Sergio Rugik Gomes.

Figura 9: Menorah em eposição no bairro judeu em Jerusalém. Foto: Sergio Rugik Gomes.

Figura 10: Planta atual do monte do Templo com sua possível antiga localização. $\quad$ Fonte:<http://www.bible.ca/archeology/bible-archeologyjerusalem-temple-mount-dome-of-tablets.htm> Acesso em: 05 jan. 2011....... 24

Figura 11: Reconstituição da planta do Templo de Jerusalém. Fonte:<http://www.sacred-destinations.com/israel/images/jerusalem/templemount/resized/herod-temple-floor-plan-nc-aug-edu.jpg> Acesso em: 05 jan. 2010.

Figura 12: Rolos da Torah e escudo no interior da arca da sinagoga askenazita de Santos.Foto: Sergio Rugik Gomes.

Figura 13: Escudo de prata para adorno da Torah em exposição no Metropolitam Museum de Toronto, Canadá. Foto: Sergio Rugik Gomes.

Figura 14: Vista da arca e bimah juntas na Sinagoga Beit Sion em Santos. Foto: Sergio Rugik Gomes.

Figura 15: Pergaminho da Torah aberta em mesa na sinagoga de Kiriat Yam, Israel Foto: Sergio Rugik Gomes.

Figura 16: Plataforma de leitura (bimah) com a arca ao fundo na sinagoga

Beit Jacob em Santos. Foto: Sergio Rugik Gomes 
Figura 17: Vista da arca e bimah na sinagoga Beit Jacob em santos. Foto: Sergio Rugik Gomes.

Figura 18: Judeu recitando a benção antes da leitura da Torah.Foto: Sergio Rugik Gomes.

Figura 19: Sukah em praça do bairro judeu em Jerusalém, Israel. Foto: Sergio Rugik Gomes.

Figura 20: Balcão para as mulheres na sinagoga Beit Zion em Santos (1935). Foto: Sergio Rugik Gomes.

Figura 21: Mikveh na antiga sinagoga de Cafarnaum, Israel. Foto: Sergio Rugik Gomes.

Figura 22: A menorah na fachada da sinagoga Francisco Frischmann em Curitiba. Foto: Sergio Rugik Gomes.

Figura 23: foto aérea da fortaleza de Massada, Israel. Fonte: <http:// http://imperioroma.blogspot.com/2010/06/massada-ultima-fortaleza.htm> Acesso em: 13/12/2010.

Figura 24: Planta da sinagoga de Massada (editado pelo autor). Fonte: Levine, 2005.

Figura 25: Reconstituição da sinagoga de Massada. Fonte: Gravura de Lev Filipp - Israel Nature and Parks Authority.

Figura 26: Foto aérea da sinagoga de Massada com destaque para 0 cômodo da Torah (destaque do autor). Fonte: <http://www.pohick.org/sts/masada.html> Acesso em: 10/12/2010. .....

Figura 27: Foto das ruínas da sinagoga de Delos com possível mikveh. Fonte:<http://synagogues360.net/synagogues.php?ident=greece_004>

Acesso em: $10 \mathrm{dez}$. 2010

Figura 28: Planta da sinagoga de Delos, Grécia. Fonte: <http://www.pohick.org/sts/delos.html> Acesso em: 10 dez. 2010.................. 52

Figura 29: Plantas da sinagoga e de outras edificações em Delos (edição do autor). Fonte: Matassa (2010).

Figura 30: Imagem da cadeira entalhada na sinagoga de Delos. Fonte: <http://synagogues360.net/synagogues.php?ident=greece_004> Acesso em: 10 dez. 2010.

Figura 31: Detalhe de nicho na sinagoga de Gamla. Fonte: <http://www.nd.edu/ daune/near_east_arch/gamla/gamla.htm> Acesso em: 10 dez. 2010......

Figura 32: Planta da sinagoga de Gamla (legendas do autor). Fonte: $<$ http://cnes.cla.umn.edu/courses/archaeology/Gamla/GamlaSynagogue.ht ml> Acesso em: 09 dez. 2010.

Figura 33: Reconstituição da sinagoga de Gamla. Fonte: $<$ http://www.esvstudybible.org/blog/2008/08/the-gamla-synagogue-in-theesv-study-bible/> Acesso em: 09 dez. 2010. 
Figura 34: Imagens das ruínas da sinagoga de Gamla. Fonte: <http://benwitherington.blogspot.com/2008/11/gamla-synagogue.html> Acesso em: $10 \mathrm{dez} .2010$.

Figura 35: Pátio com fonte para purificação na sinagoga de Sardes. Fonte: <http://www.biblediscovered.com> Acesso em: 30 nov. 2010

Figura 36: Ruínas do acesso oeste ao Templo em Jerusalém. Foto: Sergio Rugik Gomes.

Figura 37: Reconstituição do conjunto de edifícios e sinagoga em Dura Europos. (destaque e comentários do do autor) Fonte: <http://commons.wikimedia.org/wiki/Category:Dura-Europos_synagogue> Acesso em: 30 nov. 2010.

Figura 38: Planta da sinagoga de Dura Europos (edição e comentários do autor).

Fonte: <http://commons.wikimedia.org/wiki/File:Dura_Europos_L7_City_Block.svg> Acesso em: 13 dez. 2010.

Figura 39: Planta da sinagoga de Ostia (edição do autor). Fonte: <http://ostiasynagogue.wordpress.com/> Acesso em: 13 dez. 2010..

Figura 40: Vista da cozinha com forno na sinagoga de Ostia. Fonte: <http://catholic-resources.org/AncientRome/ost12-8.jpg> Acesso em: 30 nov. 2010

Figura 41: Entrada do salão principal com aedicula à direita e propylaeum à direita. Fonte: <http://picasaweb.google.com/lh/photo/d1JCUxGNtwXfcR45O7n3eg> Acesso em: 30 nov. 2010.

Figura 42: Vista aérea do contexto urbano de Ostia. Fonte: <http://www.topromantours.com/tours.htm> Acesso em: 30 nov. 2010.

Figura 43: Planta do complexo e sinagoga de Sardes com destaque para a sinagoga (edição do autor).Fonte: Fine, 1999.

Figura 44: Planta da sinagoga de Sardes. Fonte: Levine, 2005.

Figura 45: Vista do corpo da sinagoga de Sardes. Fonte: <http://sitemaker.umich.edu/late-antiquity/files/sardissyn.jpg> Acesso em: 30 nov. 2010.

Figura 46: Átrio da sinagoga de Sardes. Fonte: <http://www.corbisimages.com/Enlargement/VN004588.html> Acesso em: 4 dez. 2010.

Figura 47: Exedra aos fundos da sinagoga de Sardes. Fonte: <http://www.sbhseattle.org/> Acesso em: 30 nov. 2010

Figura 48: Santuários da Torah em Sardes. Fonte: <http://www.bibleplaces.com/sardis.htm> Acesso em: 30 nov. 2010...

Figura 49: Salão de orações da sinagoga de Sardes. Fonte: <http://www.turkeyinphotos.com/photos/sardis/> Acesso em: 14 nov. 2010.... 70

Figura 50: Reconstituição das sinagoga de Sardes e Ostia. Fonte: FINE, 1999. 
Figura 51: Detalhe da parede oeste com aedicula. Fonte: <http://2.bp.blogspot.com/_CijcaA9yq58/SomavkZI2TI/AAAAAAAADMw/T6 XUai3WWYs/ Acesso em: 30 nov. 2010

Figura 52: Imagens utilizadas nas sinagogas de Dura Europos e Sardes.Fonte:<http://arthistorymadness.blogspot.com/2007/10/duraeuropos.html> Acesso em: 30 nov. 2010.

Figura 53: Interior da sinagoga "Santa Maria la Blanca" em Toledo, Espanha.

Fonte:<http://photography.nationalgeographic.com/photography/enlarge/san ta-maria-la-blanca_pod_image.html> Acesso em: 16 dez. 2010

Figura 54: Foto aérea do gueto de Veneza. Fonte: <http://www.elitehotel.it/pt/the_ancient_jewish_ghetto_in_venice_13pt1341e n.html> Acesso em: 22 dez. 2010.

Figura 55: Planta da sinagoga Scuola Tedesca em Veneza, Italia (1528).Fonte:<KRINSKY,1996/http://www.flickr.com/photos/dkonn/4604847 715/> Acesso em: 24 dez. 2010.

Figura 56: Exterior reconstruído da sinagoga de Worms, Alemanha (1174).Fonte:<http://farm2.static.flickr.com/1242/1118281278_89879fd60f_z .jpg?zz=1> Acesso em: 07 jan. 2011.

Figura 57: Fachada da sinagoga escuola tedesca de Veneza. Fonte: <http://www.flickr.com/photos/dkonn/4604847715/> Acesso em:22 dez. 2010

Figura 58: Interior da sinagoga escuola tedesca de Veneza. Fonte:<http://www.savevenice.org/atf/ct/\%7B7689922E-FEAE-4D29-9DD5 777AAA62F12\%7D/Tedesca_intLG.jpg> Acesso em: 24 jan. 2011.

Figura 59: Uma das fachadas da sinagoga "Santa Maria la Blanca" em Toledo,Espanha.

Fonte:<http://travel.webshots.com/photo/1391523245073069327QLccrS>

Acesso em: $21 \mathrm{dez} .2010$.

Figura 60: Ornamentos no interior da sinagoga "Santa Maria la Blanca" em Toledo.

Fonte:<http://images.travelpod.com/users/slice_n_dice/1.1289599689.1_sa nta-maria-la-blanca-synagoga.jpg > Acesso em: 23 jan. 2011

Figura 61: Planta de Santa Maria la Blanca. Fonte: MARKMAN, 2003.

Figura 62: Planta e fachada da sinagoga renascentista de Livorno, Italia (1693). Fonte: KRINSKY, 1996

Figura 63: Interior na sinagoga de Worms (1175), com arca sobre degraus ao fundo.

Fonte: <http://upload.wikimedia.org/wikipedia/commons/thumb/a/a3/WormsSynago gelnnen.jpg/250px-WormsSynagogelnnen.jpg> Acesso em: 03 dez. 2010..... 84

Figura 64: Interior da sinagoga de Lancut. Fonte: <http://upload.wikimedia.org/wikipedia/commons/9/9a/\%C5\%81a\%C5\%84c ut_synagoga_06.jpg > Acesso em: 08 fev. 2011. 
Figura 65: Planta da Sinagoga de Worms, Alemanha. Fonte: KRINSKY (1996).

Figura 66: Fachada reconstruída da sinagoga da rua Oranienburg em Berlim (1859). Fonte: <farm1.static.flickr.com/173/376909088_5d24deedcd.jpg> Acesso em: 10 jan. 2011.

Figura 67: Fachada e interior da sinagoga de Budapest. Fonte:<image59.webshots.com/59/2/91/98/2529291980010442789wMpZal fs.jpg> Acesso em: 03 jan. 2011.

Figura 68: Fachada da sinagoga de Florença. Fonte: <http://richardmcbee.com/words/florence.jpg > Acesso em: 03 jan. 2011 ....... 91

Figura 69: Aplicação dos Dez Mandamentos na fachada da sinagoga de Florença. Fonte:<http://www.planetware.com/i/photo/synagogue-florenceir1377.jpg > Acesso em: 03 jan. 2011.

Figura 70: Fachada da sinagoga de Varsóvia com a aplicação da menorah .Fonte:<http://www.thejmca.com/TlomatskAlpha.jpg> Acesso em: 03 jan. 2011.

Figura 71: Fachada e corte da sinagoga de Zilina. Fonte: <http://collections.yadvashem.org/photosarchive/s637469/11694356157076 661996.jpg > Acesso em: 11 jan. 2011.

Figura 72: Fachada da sinagoga de Plauen, Alemanha.Fonte: KRINSKY, 1996.

Figura 73: Interior da sinagoa de Plauen. Fonte<http://www.tudarmstadt.de/vorbeischauen/aktuell/nachrichten_1/synagogenexhibition.en.j sp?aktuelles_bild=15\&galerie=2904383\#bildergalerie> Acesso em: 05 jan. 2011.

Figura 74: Plantas da sinagoga de Warsaw. Fonte: Krinsky, 1996.

Figura 75: Plantas da sinagoga de Berlin. Destaque para bimah junto à arca $\mathrm{e}$ instalações voltadas às mulheres (edição do autor). Fonte:<upload.wikimedia.org/wikipedia/commons/6/61/Berlin_Synagoge_Or anienburgerstrasse_Grundriss.jpg > Acesso em: 03 jan. 2011.

Figura 76: Planta da sinagoga de Zilina, com destaque (do autor) para a bimah junto da arca.Fonte: KRINSKY, 1996.

Figura 77: Edifício reconstruído em 2010 da sinagoga Hurva em Jerusalém. Foto: Sergio Rugik Gomes.

Figura 78: Planta da sinagoga B'nai Amoona, em St. Louis, Estados Unidos (editada pelo autor). Fonte: (JAMES-CHAKRABORTY, 2000 in EKERMAN, 2007)

Figura 79: Fachada do complexo da sinagoga B'nai Amoona em St. Louis, Estados, Unidos. Fonte:<http://www.bluffton.edu/ sullivanm/missouri/stlouis/temple/entrance.j pg> Acesso em: 27 jan. 2011.

Figura 80: Planta da sinagoga da Universidade Hebraica de Jerusalém.Fonte: DEKEL-CASPI, 2005. 
Figura 81: A sinagoga antiga renascentista em Livorno e sua substituta no pós-guerra.Fonte: KRINSKY, $1985 . \quad$ Fonte: <http://www.jewishvirtuallibrary.org/jsource/images/ltaly/legsyn1.jpg> Acesso em: 19 jan. 2011.

Figura 82: Interior da sinagoga de Livorno do pós-guerra. Fonte: $<$ http://www.jewishitaly.net/immagini/livornosynagogue.jpg > Acesso em: 19 jan. 2011

Figura 83:Fachada da sinagoa da Universidade Hebraica de Jerusalém, Israel.Fonte: DEKEL-CASPI, 2005.

Figura 84: Interior da sinagoga B'nai Amoona em St. Louis, Estados Unidos. Fonte: JAMES-CHAKRABORTY, 2000 in EKERMAN, 2007.

Figura 85: Planta da proposta de Loius Kahn para reconstrução da sinagoga Hurva. Fonte:<http://www.stoa-architecture.com/theorie/wpcontent/uploads/Image/Histoire 20.jpg > Acesso em: 07 fev. 2011 ................ 108

Figura 86: Seção em 3D da proposta de Louis Kahn para sinagoga Hurva. Fonte:<http://israeltours.files.wordpress.com/2011/01/model-hurvasynagogue-exterior.jpg > Acesso em: 07 fev. 2011.

Figura 87: Planta da sinagoga cymbalista em Tel Aviv, Israel. Fonte: PELLANDINI, 2001 IN EKERMAN, 2007

Figura 88: Fachada da sinagoga Cymbalista em Tel Aviv, Israel. Fonte: <http://upload.wikimedia.org/wikipedia/commons/thumb/6/63/Synagoge_auf _Gelaende_der_Universtaet_Tel_Aviv.jpg/800pxSynagoge_auf_Gelaende_ der_Universtaet_Tel_Aviv.jpg > Acesso em: 10 fev. 2011.

Figura 89: Desenhos esquemáticos do Tabernáculo (1) e do Templo (2) com destaque para a Arca (A). Fonte: Sergio Rugik Gomes 